\title{
A taxonomic guide to modern benthic shelf foraminifera of the western Mediterranean Sea
}

\author{
Yvonne Milker and Gerhard SchmiedI
}

\begin{abstract}
A total of 288 modern benthic carbonate shelf foraminifera in three areas of the Western Mediterranean Sea (Alboran Platform, Oran Bight and the southwest shelf of Mallorca) have been studied and are systematically listed. This systematic description provides a list of synonyms, short remarks about morphological features of the taxa and some annotations about taxa with problematic generic status. Most of the taxa are illustrated by SEM photographs.
\end{abstract}

Yvonne Milker. Geological-Paleontological Institute and Museum (GPI u. M.), University of Hamburg, Bundesstrasse 55, 22307 Hamburg. Present address: Department of Geosciences, University of Tuebingen, Hoelderlinstrasse 12, 20146 Tuebingen. Yvonne.Milker@uni-tuebingen.de Gerhard Schmiedl. Geological-Paleontological Institute and Museum (GPI u. M.), University of Hamburg, Bundesstrasse 55, 20146 Hamburg. Gerhard.Schmiedl@uni-hamburg.de

KEY WORDS: benthic foraminifera; Western Mediterranean Sea; Holocene; taxonomy; shelf

\section{INTRODUCTION}

Foraminifera are a widely distributed and diverse order of protists in marine environments. They play an important role in ecological and paleo-ecological studies due to their high numerical density in marine sediments and the excellent preservation potential of their shells. Benthic foraminifera show a great diversity with more than 10,000 modern taxa (Sen Gupta, 2003). An accurate knowledge of the taxonomy of foraminifera provides the basis for any applications in paleoenvironmental or biostratigraphic studies of these protozoa. In the early eighteenth century, Scheuchzer was the first who identified foraminifera as animals, and he assigned them to the gastropoda
(Nuglisch, 1985). Lamarck established independent foraminiferal orders such as Discorbis, Rotalia, Lenticulina and Nummulites in 1801 and 1804 (Nuglisch, 1985). D'Orbigny, who played an important role in foraminiferal research, categorized foraminifera as their own order inside the cephalopoda in 1826, and Dujardin assigned them to the protozoa in 1841 (Nuglisch, 1985). Since the first investigations, more systematic studies were carried out by Reuss, Ehrenberg and later by Thalman. An important monograph about modern foraminifera based on the material collected during the Challenger expedition (1872-1876) was published by Brady (1884) and later republished in revised forms by Barker (1960) and Jones (1994). In the 
early twentieth century, Cushman was one of the leading researchers of foraminiferal taxonomy. The last magnum opus on foraminifera dates back to 1988, when Loeblich and Tappan published a comprehensive work about the taxonomy of foraminifera with a description of 878 genera.

The Mediterranean Sea is a classical region for investigations in foraminiferal taxonomy. D'Orbigny described numerous current taxa from the Mediterranean region in 1826. Further, more scientists such as Parker (1958) and Todd (1958) investigated deep sea benthic and planktonic foraminifera from the Eastern and Western Mediterranean Sea, collected during the Swedish Deep Sea Expedition (1946-1948) and the Atlantic cruise 151 (1948). Hofker (1960) investigated the taxonomy of shallow water benthic foraminifera from the Gulf of Naples. More recent comprehensive and systematic descriptions were provided by Cimerman and Langer (1991) for the Adriatic and Tyrrhenian Seas, by Sgarrella and Moncharmont Zei (1993) from the Gulf of Naples, and by Rasmussen (2005) from the southern Aegean Sea. Besides these works, there are many additional publications about foraminiferal taxonomy from the Mediterranean Sea (among others, Alberola et al., 1987; Jorissen, 1987; Mendes et al., 2004; Frezza and Carboni, 2009), and the Sea of Marmara (e.g., Kaminski et al., 2002; Chendes et al., 2004; Avsar et al., 2006).

\section{OCEANOGRAPHIC SETTINGS}

The surface water in the Western Mediterranean Sea consists of inflowing surface water from the Atlantic Ocean (AW). The subsurface water consists of Levantine Intermediate Water formed in the Eastern Mediterranean Sea, and the deep water consists of Western Mediterranean Deep Water (Robinson et al., 2001; Masque et al., 2003; Rixen et al., 2005). The AW enters the Alboran Basin in the form of two anticyclonic gyres - the Western Alboran Gyre (WAG) and the Eastern Alboran Gyre (EAG). These gyres are zones of enhanced vertical mixing and nutrient entrainment (L'Helguen et al., 2002; Masque et al., 2003; VelezBelchi et al., 2005). The Oran Bight region is influenced by the variable Algerian Current, flowing along the Algerian coast. It supplies the coastal regions with elevated nutrient loads and is characterized by higher chlorophyll a values when compared to the more oligotrophic Algerian Basin (Millot et al., 1990; Arnone, 1994). As a consequence of these oceanographic settings, the Alboran Basin and the Oran Bight exhibits higher annual primary production rates when compared to the more oligotrophic Balearic region (Antoine et al., 1995).

On the Alboran Platform and in the Oran Bight, surface water velocities are relatively high. Velez-Belchi et al. (2005) have measured velocities of the WAG between 124 and $140 \mathrm{~cm} / \mathrm{s}$ in October 1996. In contrast, surface water velocities southwest off Mallorca are lower and ranging between < $15 \mathrm{~cm} / \mathrm{s}$ and a maximum of $50 \mathrm{~cm} / \mathrm{s}$ during storm events (Werner et al., 1993).

\section{MATERIAL AND METHODS}

For this study, surface samples and sedimentcores from three areas in the Western Mediterranean Sea (Alboran Platform, Oran Bight and the southwest shelf off Mallorca), recovered during Meteor cruise M69/1 in August 2006, were investigated (Table 1, Figures 1, 2, 3, 4). Surface samples were taken with box and grab corer, and the first 1 $2 \mathrm{~cm}$ of the sediment was stained in an ethanolBengal Rosa solution for three months. Three sediment cores (core 342-1 from Alboran Platform, core 367-1 from Oran Bight and core 401-1 from Mallorca Shelf) were recovered from water depths, ranging from 63 to $74 \mathrm{~m}$, by vibro coring (Table 1 , Figures 2, 3, 4).

All samples were wet-sieved with a $63 \mu \mathrm{m}$ sieve and dried in a dry oven at $40^{\circ} \mathrm{C}$. For recent and fossil foraminiferal investigation, the fraction $>125 \mu \mathrm{m}$ has been counted after dry-sieving. Samples were split into equal aliquots to generate subsamples with approximately 300 empty benthic foraminiferal tests. Due to the low contents of Rose Bengal stained foraminifera in the surface samples, higher sample volumes were investigated. The cores were analyzed in a resolution of $5 \mathrm{~cm}$ except core 342-1, which was analyzed in a resolution of $20 \mathrm{~cm}$ in its lower part. A total of 14 surface samples are from the Alboran Platform, 18 surface samples are from the Oran Bight and 14 surface samples are from the Mallorca Shelf, ranging from 20 to $235 \mathrm{~m}$ water depth, was investigated. The cores contain a total of 64 (core 342-1), 58 (core 367-1) and 94 (core 401-1) samples and cover the latest glacial period (core 342-1) and the Holocene (cores 367-1 and 401-1).

In order to extract dominant recent and fossil assemblages and for the investigation of speciesenvironment relations, statistical methods (Principal Component Analysis (PCA) and Redundany Analysis (RDA)) were applied on the recent and fossil assemblages. For a description of these methods see Milker et al. (2009). The age models 
TABLE 1. Location and water depth of the surface samples and sediment cores (in bold). Surface samples were taken with box and grab corer (BG, KG) and from top of sediment cores recovered with vibrocorer (VC*). All cores were drilled with vibrocorer (VC).

\begin{tabular}{|c|c|c|c|c|c|c|}
\hline No. & Location & Date & Latitude & Longitude & $\begin{array}{c}\text { Depth } \\
{[\mathrm{m}]}\end{array}$ & Gear \\
\hline $326-1$ & Alboran Platform & 16.08 .2006 & $35^{\circ} 52.450^{\circ} \mathrm{N}$ & $3^{\circ} 05.150^{\prime} \mathrm{W}$ & 102 & $B G$ \\
\hline $327-1$ & Alboran Platform & 16.08 .2006 & $35^{\circ} 53.890^{\prime} \mathrm{N}$ & $3^{\circ} 05.950^{\prime} \mathrm{W}$ & 115 & $B G$ \\
\hline $328-1$ & Alboran Platform & 16.08 .2006 & $35^{\circ} 55.130^{\circ} \mathrm{N}$ & $3^{\circ} 03.311^{\prime} \mathrm{W}$ & 69 & BG \\
\hline $329-1$ & Alboran Platform & 16.08 .2006 & $35^{\circ} 55.200^{\circ} \mathrm{N}$ & $3^{\circ} 02.820^{\prime} \mathrm{W}$ & 60 & BG \\
\hline $330-1$ & Alboran Platform & 16.08.2006 & $35^{\circ} 56.200^{\prime} \mathrm{N}$ & $3^{\circ} 00.690^{\prime} \mathrm{W}$ & 63 & BG \\
\hline $331-1$ & Alboran Platform & 16.08 .2006 & $35^{\circ} 59.300^{\prime} \mathrm{N}$ & $2^{\circ} 59.500^{\prime} \mathrm{W}$ & 86 & $B G$ \\
\hline $332-2$ & Alboran Platform & 16.08 .2006 & $35^{\circ} 59.510^{\prime} \mathrm{N}$ & $2^{\circ} 57.210^{\prime} \mathrm{W}$ & 83 & $B G$ \\
\hline $333-1$ & Alboran Platform & 16.08 .2006 & $36^{\circ} 00,655^{\prime} \mathrm{N}$ & $2^{\circ} 49,732^{\prime} \mathrm{W}$ & 161 & $B G$ \\
\hline $334-1$ & Alboran Platform & 16.08 .2006 & $35^{\circ} 57.500^{\prime} \mathrm{N}$ & $2^{\circ} 56.020^{\prime} \mathrm{W}$ & 97 & $B G$ \\
\hline $335-1$ & Alboran Platform & 16.08 .2006 & $35^{\circ} 58.035^{\prime} \mathrm{N}$ & $2^{\circ} 59.890^{\prime} \mathrm{W}$ & 73 & $B G$ \\
\hline $336-1$ & Alboran Platform & 16.08 .2006 & $35^{\circ} 54.450^{\prime} \mathrm{N}$ & $3^{\circ} 05.535^{\prime} \mathrm{W}$ & 91 & $B G$ \\
\hline $341-2$ & Alboran Platform & 17.08 .2006 & $35^{\circ} 55.103^{\prime} \mathrm{N}$ & $3^{\circ} 02.194^{\prime} \mathrm{W}$ & 53 & $\mathrm{VC}^{*}$ \\
\hline $342-1$ & Alboran Platform & 17.08 .2006 & $35^{\circ} 56.400^{\circ} \mathrm{N}$ & $3^{\circ} 00.213^{\prime} \mathrm{W}$ & 64 & $\mathrm{VC}^{*}$ \\
\hline $342-1$ & Alboran Platform & 17.08.2006 & $35^{\circ} 56.400^{\prime} \mathrm{N}$ & $3^{\circ} 00.213^{\prime} \mathrm{W}$ & 64 & Vc \\
\hline $343-2$ & Alboran Platform & 17.08 .2006 & $35^{\circ} 55.588^{\prime} \mathrm{N}$ & $3^{\circ} 01.915^{\prime} \mathrm{W}$ & 38 & $V C^{*}$ \\
\hline $351-1$ & Oran Bight & 19.08 .2006 & $35^{\circ} 48.490^{\circ} \mathrm{N}$ & $0^{\circ} 34.000^{\prime} \mathrm{W}$ & 70 & BG \\
\hline $352-1$ & Oran Bight & 19.08 .2006 & $35^{\circ} 47.500^{\prime} \mathrm{N}$ & $0^{\circ} 33.810^{\prime} \mathrm{W}$ & 48 & $K G$ \\
\hline $353-1$ & Oran Bight & 19.08 .2006 & $35^{\circ} 47.230^{\prime} \mathrm{N}$ & $0^{\circ} 37.650^{\prime} \mathrm{W}$ & 73 & $B G$ \\
\hline $354-1$ & Oran Bight & 19.08 .2006 & $35^{\circ} 45.872^{\prime} \mathrm{N}$ & $0^{\circ} 40.232^{\prime} \mathrm{W}$ & 84 & $B G$ \\
\hline $355-1$ & Oran Bight & 19.08 .2006 & $35^{\circ} 50.696^{\prime} \mathrm{N}$ & $0^{\circ} 35.306^{\prime} \mathrm{W}$ & 127 & $B G$ \\
\hline $356-1$ & Oran Bight & 19.08 .2006 & $35^{\circ} 50.207^{\prime} \mathrm{N}$ & $0^{\circ} 35.000^{\prime} \mathrm{W}$ & 118 & $B G$ \\
\hline $357-1$ & Oran Bight & 19.08.2006 & $35^{\circ} 51.204^{\prime} \mathrm{N}$ & $0^{\circ} 33.092^{\prime} \mathrm{W}$ & 100 & $B G$ \\
\hline $357-2$ & Oran Bight & 19.08 .2006 & $35^{\circ} 51.198^{\prime} \mathrm{N}$ & $0^{\circ} 33.092^{\prime} \mathrm{W}$ & 100 & $\mathrm{KG}$ \\
\hline $358-1$ & Oran Bight & 20.08 .2006 & $35^{\circ} 50.802^{\prime} \mathrm{N}$ & $0^{\circ} 32.700^{\prime} \mathrm{W}$ & 85 & $B G$ \\
\hline
\end{tabular}

for the cores are based on various $\mathrm{AMS}^{14} \mathrm{C}$ measurements. For further information see Milker et al. (2011).

All surface samples and cores were taken from cool-water carbonates areas that are protected from major siliciclastic input. The surface and core sediments from the Alboran Platform consist of calcarenites and calcirudites with an admixture of volcanoclastic debris that contain rhodoliths, bioclasts, bryozoa, mollusc-shells and shell debris. The two shallowest samples $(20 \mathrm{~m}$ and $40 \mathrm{~m}$ water depth) from Oran Bight consists of siliciclastic sands, while the other surface and core sediments also consist of calcirudites and calcarenites with rhodoliths, lithoclasts encrusted by coralline crusts, bivalves and gastropods. The surface samples from the shallower sites off the southwest shelf of Mallorca shelf have a composition similar to those from the Alboran Platform and Oran Bight, while the sediments of the deeper stations are composed of fine-grained calcarenite and contain a few sea grass fragments. The lower core part of core 401-1 from the Mallorca Shelf consists of calcirudite with rhodoliths. The middle and upper parts of the core are composed of fine-grained calcarenites with debris and shells of bivalves, pteropods and gastropods and a Turritella communis-rich layer in its middle part. For detailed characterization of the surface and core sediments see Betzler et al. (2011) and Milker et al. (2009).

\section{SYSTEMATICS}

A total of 103 living (Rose Bengal stained) species and a total of 220 species with empty tests from the fraction $>125 \mu \mathrm{m}$ were identified on taxa level in the surface samples. In the sediment-cores $342-1,367-1$ and $401-1$, a total of 180,176 and 205 fossil benthic species were identified on taxa level (Appendix 1, 2, 3, 4, 5 - available online). Very rare species, or species that were difficult to identify, have been summarized into their genera or family. The water depth distribution of the recent 
TABLE 1 (continued).

\begin{tabular}{|c|c|c|c|c|c|c|}
\hline $359-1$ & Oran Bight & 20.08 .2006 & $35^{\circ} 50.200^{\prime} \mathrm{N}$ & $0^{\circ} 32.000^{\prime} \mathrm{W}$ & 78 & BG \\
\hline $360-1$ & Oran Bight & 20.08 .2006 & $35.49 .890^{\circ} \mathrm{N}$ & $0^{\circ} 31.600^{\prime} \mathrm{W}$ & 83 & BG \\
\hline $361-1$ & Oran Bight & 20.08 .2006 & $35^{\circ} 49.990^{\prime} \mathrm{N}$ & $0^{\circ} 30.510^{\prime} \mathrm{W}$ & 67 & $B G$ \\
\hline $362-1$ & Oran Bight & 20.08 .2006 & $35^{\circ} 50.895^{\prime} \mathrm{N}$ & $0^{\circ} 29.4966^{\prime} \mathrm{W}$ & 20 & KG \\
\hline $363-1$ & Oran Bight & 20.08 .2006 & $35^{\circ} 52.110^{\prime} \mathrm{N}$ & $0^{\circ} 30.500^{\prime} \mathrm{W}$ & 97 & $B G$ \\
\hline $364-1$ & Oran Bight & 20.08 .2006 & $35^{\circ} 52.900^{\prime} \mathrm{N}$ & $0^{\circ} 30.800^{\prime} \mathrm{W}$ & 121 & BG \\
\hline $365-1$ & Oran Bight & 20.08 .2006 & $35^{\circ} 53.900^{\prime} \mathrm{N}$ & $0^{\circ} 31.297^{\prime} \mathrm{W}$ & 130 & BG \\
\hline $367-1$ & Oran Bight & 20.08 .2006 & $35^{\circ} 48.000^{\prime} \mathrm{N}$ & $0^{\circ} 33.700^{\prime} \mathrm{W}$ & 63 & VC \\
\hline $373-1$ & Oran Bight & 20.08 .2006 & $35.49 .664^{\prime} \mathrm{N}$ & $0^{\circ} 34.673^{\prime} \mathrm{W}$ & 90 & $B G$ \\
\hline $374-1$ & Oran Bight & 20.08 .2006 & $35^{\circ} 50.005^{\prime} \mathrm{N}$ & $0^{\circ} 34.886^{\prime} \mathrm{W}$ & 100 & $B G$ \\
\hline $375-1$ & Oran Bight & 20.08 .2006 & $35.51 .105^{\prime} \mathrm{N}$ & $0^{\circ} 35.526^{\prime} \mathrm{W}$ & 115 & $B G$ \\
\hline $377-1$ & Mallorca Shelf & 24.08 .2006 & $39^{\circ} 18.879^{\prime} \mathrm{N}$ & $2^{\circ} 47.827^{\prime} \mathrm{E}$ & 47 & BG \\
\hline $378-1$ & Mallorca Shelf & 24.08 .2006 & $39^{\circ} 21.192^{\prime} \mathrm{N}$ & $2^{\circ} 47.810^{\prime} \mathrm{E}$ & 40 & $B G$ \\
\hline $379-1$ & Mallorca Shelf & 24.08 .2006 & $39^{\circ} 19.601^{\prime} \mathrm{N}$ & $2^{\circ} 46.208^{\prime} \mathrm{E}$ & 48 & $B G$ \\
\hline $380-1$ & Mallorca Shelf & 24.08 .2006 & $39^{\circ} 18.098^{\prime} \mathrm{N}$ & $2^{\circ} 44.702^{\prime} \mathrm{E}$ & 56 & $B G$ \\
\hline $381-1$ & Mallorca Shelf & 24.08 .2006 & $39^{\circ} 17.005^{\prime} \mathrm{N}$ & $2^{\circ} 43.300^{\prime} \mathrm{E}$ & 67 & $B G$ \\
\hline $382-1$ & Mallorca Shelf & 24.08 .2006 & $39^{\circ} 16.101^{\prime} \mathrm{N}$ & $2^{\circ} 42.196^{\prime} \mathrm{E}$ & 74 & BG \\
\hline $384-1$ & Mallorca Shelf & 24.08 .2006 & $39^{\circ} 18.095^{\prime} \mathrm{N}$ & $2^{\circ} 49.013^{\prime} \mathrm{E}$ & 61 & BG \\
\hline $387-1$ & Mallorca Shelf & 24.08 .2006 & $39^{\circ} 15.503^{\prime} \mathrm{N}$ & $2^{\circ} 41.498^{\prime} \mathrm{E}$ & 80 & $B G$ \\
\hline $388-1$ & Mallorca Shelf & 24.08 .2006 & $39^{\circ} 15.214^{\prime} \mathrm{N}$ & $2^{\circ} 41.089^{\prime} \mathrm{E}$ & 94 & $B G$ \\
\hline $390-1$ & Mallorca Shelf & 24.08 .2006 & $39^{\circ} 14.830^{\prime} \mathrm{N}$ & $2^{\circ} 40.532^{\prime} \mathrm{E}$ & 116 & $B G$ \\
\hline $391-1$ & Mallorca Shelf & 24.08 .2006 & $39^{\circ} 13.610^{\prime} \mathrm{N}$ & $2^{\circ} 39.090^{\prime} \mathrm{E}$ & 163 & $B G$ \\
\hline $393-1$ & Mallorca Shelf & 25.08 .2006 & $39^{\circ} 10.601^{\prime} \mathrm{N}$ & $2^{\circ} 40.398^{\prime} \mathrm{E}$ & 235 & KG \\
\hline 401-1 & Mallorca Shelf & 25.08.2006 & $39^{\circ} 17.101^{\prime} \mathrm{N}$ & $2^{\circ} 48.305^{\prime} \mathrm{E}$ & 74 & VC \\
\hline $403-1$ & Mallorca Shelf & 25.08 .2006 & $39^{\circ} 14.798^{\prime} \mathrm{N}$ & $2.45 .524^{\prime} \mathrm{E}$ & 94 & $B G$ \\
\hline $404-1$ & Mallorca Shelf & 25.08 .2006 & $39^{\circ} 13.970^{\circ} \mathrm{N}$ & $2^{\circ} 44.496^{\prime} \mathrm{E}$ & 105 & BG \\
\hline
\end{tabular}

foraminifera and abundance data of the fossil foraminifera during the latest glacial period and the Holocene are provided in Table 2.

The classification of Loeblich and Tappan (1988) provides the basis for the generic classification of this study. Identification on the species level is primarily based on the publications of Cimerman and Langer (1991), Sgarrella and Moncharmont Zei (1993) and Rasmussen (2005). Furthermore, other publications about the Mediterranean Sea were studied (e.g., Parker, 1958; Hofker, 1960; Jorissen, 1987; Alberola et al., 1987; Alberola et al., 1991; Mendes et al., 2004; Debenay et al., 2005; Abu-Zied et al., 2008; Frezza and Carboni, 2009). Valuable information was also provided by comprehensive taxonomic studies from other areas, such as the Atlantic Ocean (Brady, 1884; Cushman, 1918, 1920, 1923, 1929, 1930a, 1930b and 1931; Jones, 1994), the North Pacific Ocean (Cushman, 1910, 1911, 1914, 1915 and 1917; Cushman and McCulloch, 1939) or the Red Sea (Hottinger et al., 1993). For some minor species where the original description was not available, the reference to the original description is based on the Ellis and Messina catalogue (1940-2005). In the systematic description, species within the same genus are listed in alphabetical order. The given references include publications that have an extensive list of synonyms, useful illustrations and taxa descriptions. The given remarks contain short morphological descriptions of all species. Furthermore, annotations on controversial species classifications are given. SEM photographs of most of the species were performed at the University of Hamburg with a Zeiss LEO 1455VP. Specimens described here are deposited at the University of Hamburg, Geological-Paleontological Institute.

\section{DISTRIBUTION OF RECENT AND FOSSIL BENTHIC FORAMINIFERA AND SPECIES- ENVIRONMENT RELATIONS}

A detailed description of the distribution of recent and fossil benthic foraminiferal in the study areas was already given in Milker et al. (2009, 2011). In this section, we present a summary of the results and discussions given there. Further infor- 


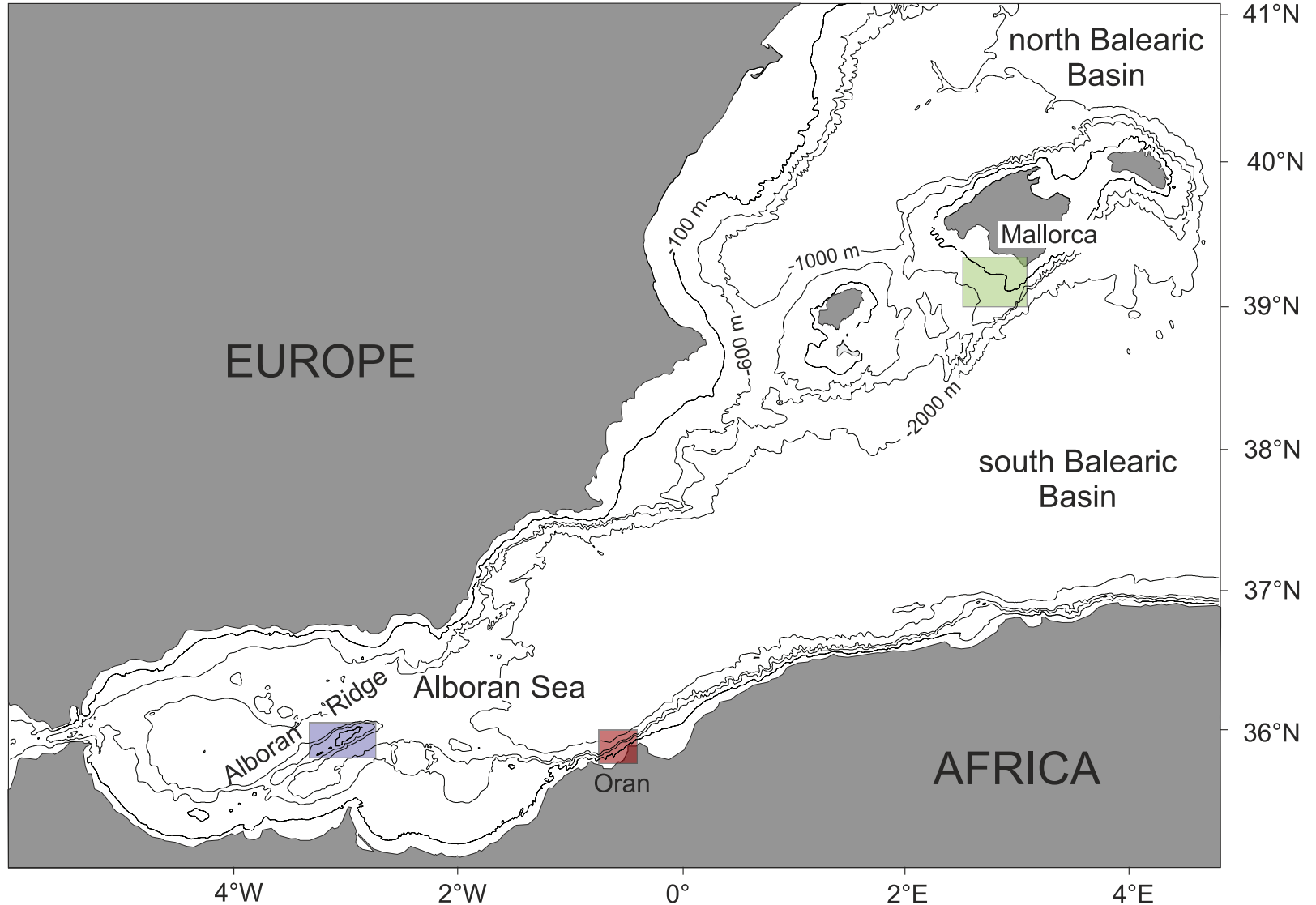

FIGURE 1. Overview of the Western Mediterranean Sea, showing the sampling areas Alboran Platform, Oran Bight and southwest shelf off Mallorca (see also Table 1). For detailed maps with sample and sediment core locations see Figures 2-4.

mation about the distribution of benthic foraminifera in the surface and core samples is also provided in Table 2.

The total number of living benthic foraminifera was generally low in the study areas while the total benthic foraminiferal number (BFN) with empty tests was highly variable, ranging between 320 and $\sim 99,000$ individuals per $10 \mathrm{~cm}^{3}$ (Figure 5). The highest standing stocks, with a maximum of 535 living individuals per $10 \mathrm{~cm}^{3}$ sediment, were observed on the Mallorca Shelf. The highest BFN with more than 99,000 individuals was reached on the Alboran Platform and the Mallorca Shelf, respectively. In the Oran Bight and on the Alboran Platform only 298 and 52 living individuals per 10 $\mathrm{cm}^{3}$ were found, respectively (Figure 5 ). The diversity of the live fauna from the Alboran Platform was low with a total of only 19 taxa while the number of taxa with empty tests ranged between 16 and 112 (Figure 5). The most abundant live species on the Alboran Platform were Cassidulina obtusa and Lenticulina orbicularis (Table 2, Appendix 1). The diversity of the live fauna from the Oran Bight was higher with a total of 76 taxa, and a total of 17-115 taxa have been observed in the thanatocoenosis (Figure 5). The biocoenosis was dominated by Cancris auriculus. Brizalina striatula, Bulimina elongata and Rectuvigerina phlegeri occurred in elevated numbers (Table 2, Appendix 1). The live fauna from the Mallorca Shelf has shown the highest diversity with a total of 83 different taxa. A total of 68-98 taxa have been observed in the thanatocoenosis (Figure 5). The samples from shallower water depths mainly consisted of living miliolids, Neoconorbina terquemi, Textularia pala and Asterigerinata mamilla s.I. The samples from the deeper sites were characterized by elevated numbers of living Cassidulina laevigata s.I., Hyalinea balthica, Textularia calva, Cassidulina obtusa and Melonis affinis (Table 2, Appendix 1).

The standing stocks and live diversities in the cool-water carbonate shelf areas discussed here display generally lower values when compared to faunas from siliciclastic shelf environments of the western Mediterranean Sea, (e.g., Mojtahid et al., 


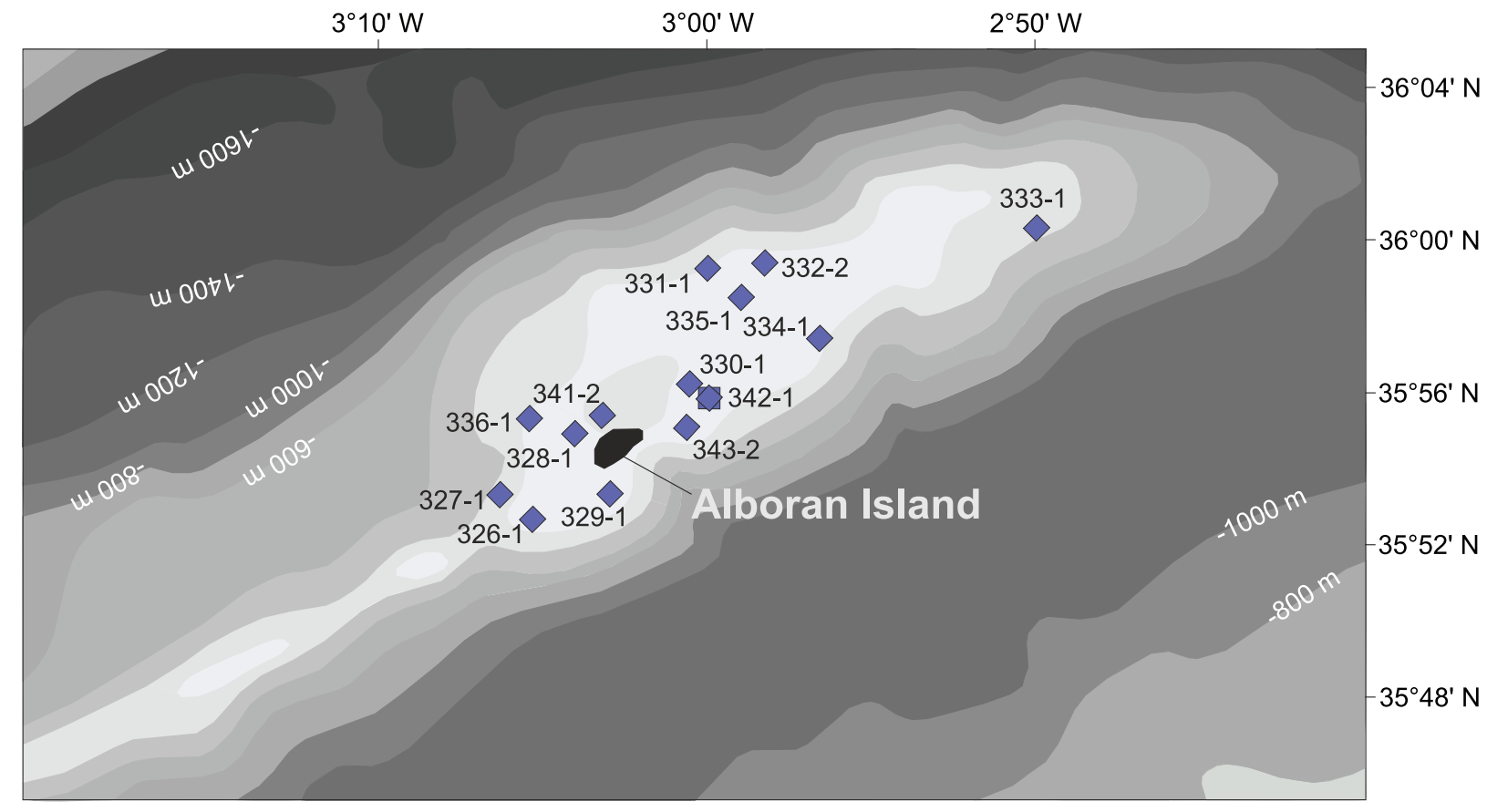

FIGURE 2. Map of the Alboran Platform region, showing the locations of the surface samples (blue diamonds) and sediment core 342-1 (blue square). Surface samples were taken from 38 to $161 \mathrm{~m}$ water depth, and the core was drilled at $64 \mathrm{~m}$ water depth.

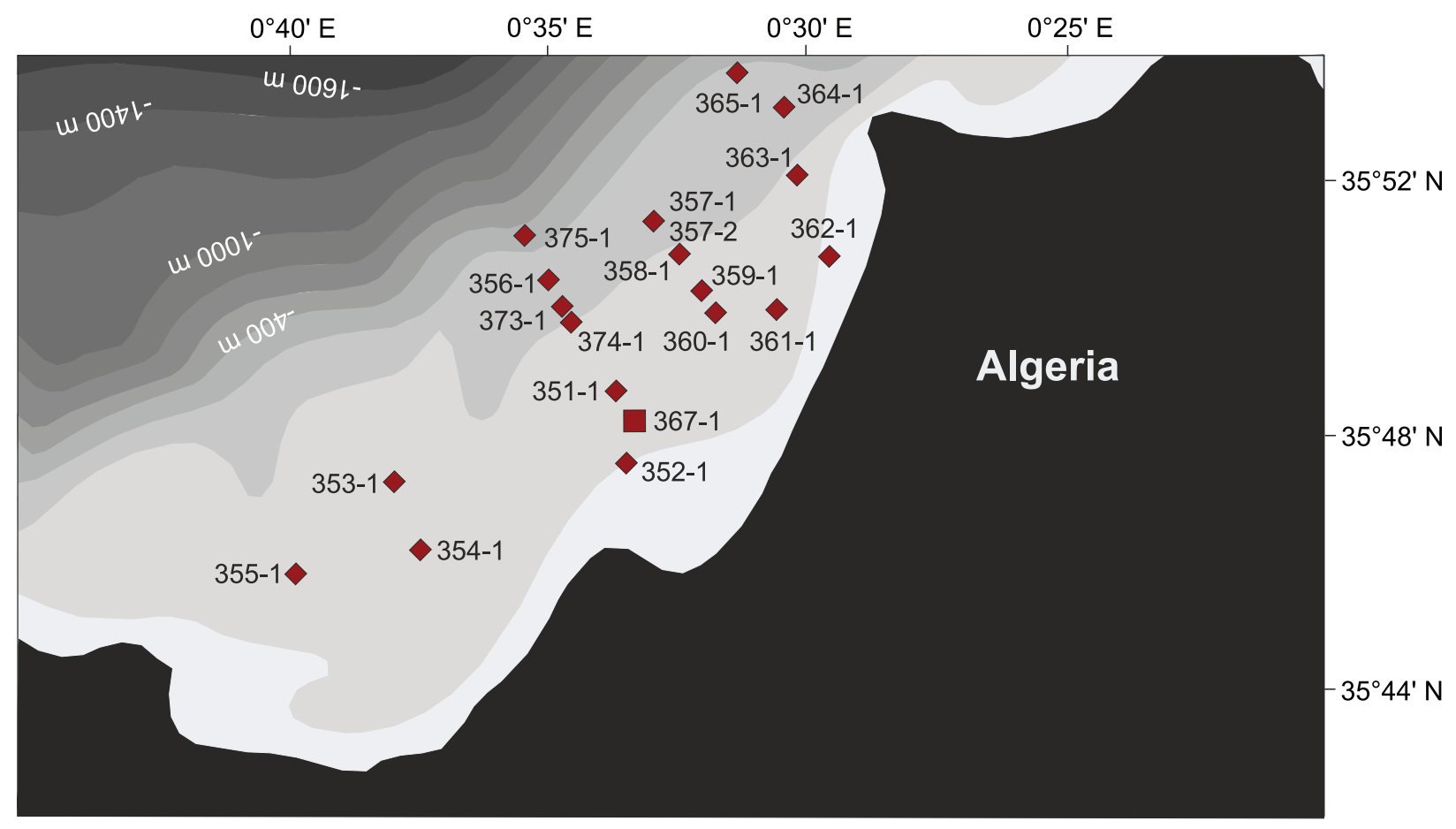

FIGURE 3. Map of the Oran Bight region, showing the locations of the surface samples (red diamonds) and sediment core 367-1 (red square). Surface samples were taken from 20 to $130 \mathrm{~m}$ water depth, and the core was drilled at $63 \mathrm{~m}$ water depth. 


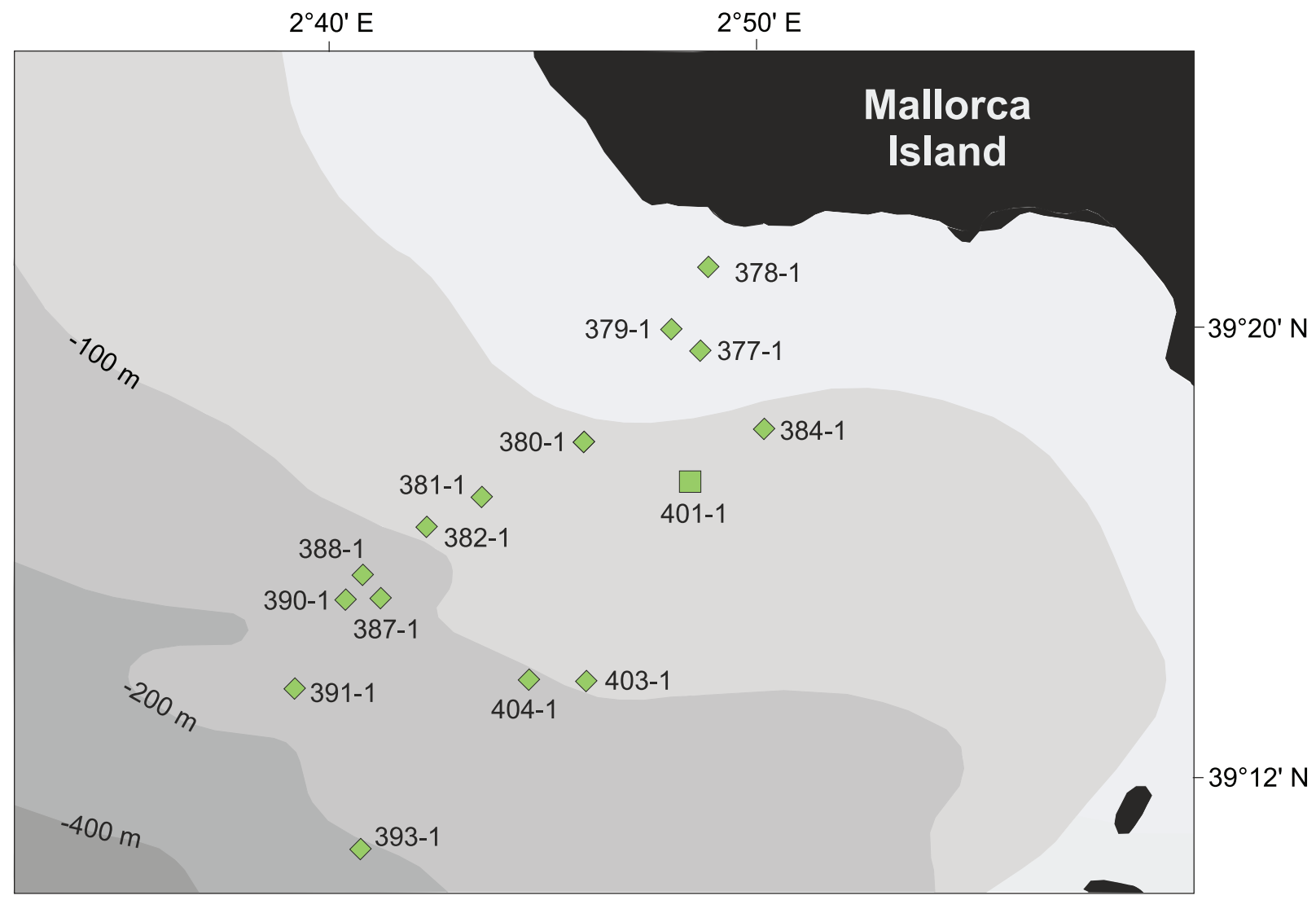

FIGURE 4. Map of the southwest Mallorca Shelf, showing the locations of the surface samples (green diamonds) and sediment core 401-1 (green square). Surface samples were taken from 40 to $235 \mathrm{~m}$ water depth, and the core was drilled at $74 \mathrm{~m}$ water depth.

2009; Frezza and Carboni, 2009). The relatively low diversities of the living fauna may reflect seasonal population dynamics. The diversities of the dead faunas have similar or even higher numbers when compared to those from siliciclastic shelf environments of the Mediterranean (Frezza and Carboni, 2009, own unpubl. data) but are slightly lower than in mixed siliciclastic-carbonate ecosystems of the southeastern Levantine shelf (HyamsKaphzan et al., 2008).

A Principal Component Analysis (PCA), applied on the dead foraminiferal data set, show major faunal shifts between $\sim 80$ and $\sim 96 \mathrm{~m}$ water depth in all study areas (Figure 6). Further, it provides evidence for regional differences in the faunal composition. The shallower stations of the Alboran Platform were dominated by an Asterigerinata mamilla s.l.-assemblage with Elphidium complanatum and Lobatula lobatula as further dominant taxa and the Cibicidoides pseudoungerianus-assemblage with Cassidulina obtusa and $A$. mamilla s.I. as associated taxa (Figure 6, Table 3). The deeper stations consisted of a C. obtusa- assemblage with Globocassidulina subglobosa as further dominant taxon and the E. complanatumassemblage with Cibicides refulgens as further dominant species (Figure 6). The shallowest sites in the Oran Bight were also dominated by an $A$. mamilla s.l.-assemblage with Rosalina macropora as further dominant taxon and a $L$. lobatula-assemblage with Neoconorbina terquemi as further dominant species (Figure 6, Table 3). At intermediate depths, a Gaudryina rudis-assemblage with $L$. lobatula as associated taxon was significant. In the deeper stations, a G. subglobosa-assemblage with C. obtusa as dominant taxon and a Cassidulina laevigata s.l.-assemblage with Globocassidulina oblonga as associated taxon dominated the thanatocoenoses (Figure 6, Table 3). The shallower sites on the Mallorca Shelf were characterized by assemblages consisting of a Lobatula lobatulaassemblage (with Textularia calva and G. rudis as further taxa), a $N$. terquemi-assemblage (with $A$. mamilla s.l. as further dominant taxon) and a Spiroplectinella sagittula-assemblage (with $A$. mamilla s.I. and L. lobatula as further dominant 
TABLE 2. Recent abundance and water depth distribution and fossil abundance of the described species. Species have been classified, depending on their abundance on the total recent and fossil assemblages in percent in the three investigated areas, into the following categories: $(0)=$ extremely rare; $0=$ very rare $(<1 \%) ; 00=$ rare $(1-5 \%) ; 000=$ frequent $(5-10 \%)$, oooo $=$ abundant $(10-25 \%)$ and $00000=$ dominant $(>25 \%)$. The distribution of fossil species that are abundant in at least $1 / 3$ of the core samples have been listed into the following time intervals: late Holocene $(\leq 3500$ cal. years BP), middle Holocene (3500 - 6500 cal. years BP), early Holocene (6500 - 11700 cal. years BP) and the late glacial period $(\geq 11700$ cal. years $B P)$. The distribution of fossil species that are extremely rare and only occur in a few core samples is not given here except for those that have been only found in the fossil assemblages ( ${ }^{*}$ summarized to Ammonia spp., ** summarized to Asterigerinata mamilla s.I.)

\begin{tabular}{|c|c|c|c|c|c|c|c|c|}
\hline \multirow[b]{2}{*}{ Species } & \multirow[b]{2}{*}{$\stackrel{\S}{\frac{\Xi}{4}}$} & \multicolumn{3}{|c|}{ Recent distribution } & \multicolumn{4}{|c|}{ Fossil distribution } \\
\hline & & 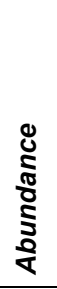 & 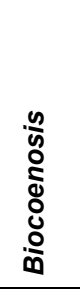 & 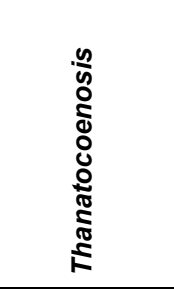 & 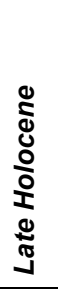 & 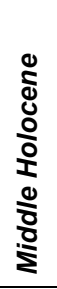 & 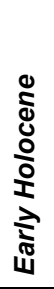 & 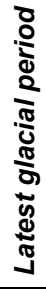 \\
\hline Acervulina inhaerens Schultze & $\begin{array}{c}\text { Oran } \\
\text { Mallorca }\end{array}$ & $\begin{array}{l}0 \\
0\end{array}$ & & $\begin{array}{c}70 \\
56-61\end{array}$ & & & & \\
\hline Adelosina colomi (Le Calvez and Le Calvez) & $\begin{array}{l}\text { Alboran } \\
\text { Mallorca }\end{array}$ & $\begin{array}{l}0 \\
0\end{array}$ & & $\begin{array}{c}83 \\
40-80\end{array}$ & & & & \\
\hline Adelosina dubia (d'Orbigny) & $\begin{array}{c}\text { Alboran } \\
\text { Oran } \\
\text { Mallorca }\end{array}$ & o & & $38-73$ & & $\begin{array}{l}0 \\
\end{array}$ & 0 & o \\
\hline Adelosina laevigata d'Orbigny & $\begin{array}{c}\text { Alboran } \\
\text { Oran } \\
\text { Mallorca }\end{array}$ & $\begin{array}{c}0 \\
\text { oo } \\
\text { oo }\end{array}$ & & $\begin{array}{c}38-83 \\
67-130 \\
40-74\end{array}$ & $\begin{array}{l}0 \\
\circ\end{array}$ & $\begin{array}{l}0 \\
\circ\end{array}$ & 0 & \\
\hline Adelosina longirostra (d’Orbigny) & $\begin{array}{c}\text { Alboran } \\
\text { Oran } \\
\text { Mallorca }\end{array}$ & $\begin{array}{l}0 \\
0\end{array}$ & & $\begin{array}{c}38-83 \\
84-118\end{array}$ & o & $\begin{array}{l} \\
0 \\
0\end{array}$ & 0 & \\
\hline $\begin{array}{l}\text { Adelosina mediterranensis (Le Calvez and Le } \\
\text { Calvez) }\end{array}$ & $\begin{array}{c}\text { Alboran } \\
\text { Oran } \\
\text { Mallorca }\end{array}$ & $\begin{array}{c}0 \\
0 \\
00\end{array}$ & 74-94 & $\begin{array}{l}38-161 \\
84-118 \\
56-116\end{array}$ & $\begin{array}{l}0 \\
\end{array}$ & o & o & \\
\hline Adelosina sp. 1 & $\begin{array}{c}\text { Alboran } \\
\text { Oran } \\
\text { Mallorca }\end{array}$ & $\begin{array}{c}0 \\
\text { oo } \\
0\end{array}$ & 67 & $\begin{array}{c}38 \\
48-130 \\
56-116\end{array}$ & $\begin{array}{l} \\
0 \\
0\end{array}$ & $\begin{array}{l}0 \\
\end{array}$ & o & \\
\hline Affinetrina gualtieriana (d'Orbigny) & $\begin{array}{l}\text { Alboran } \\
\text { Mallorca }\end{array}$ & o & & 38 & & o & $\begin{array}{l}0 \\
\circ\end{array}$ & \\
\hline Affinetrina ucrainica(Serova) & $\begin{array}{c}\text { Oran } \\
\text { Mallorca }\end{array}$ & & & & 0 & $\begin{array}{l}0 \\
\circ\end{array}$ & 0 & \\
\hline Affinetrina sp. 1 & Alboran & & & & & & (o) & \\
\hline Affinetrina sp. 2 & Alboran & & & & & & & o \\
\hline Alveophragmium scitulum (Brady) & Mallorca & (o) & & $94-235$ & & & & \\
\hline Ammodiscus minimus Hoeglund & Alboran & o & & 161 & & & & \\
\hline $\begin{array}{l}\text { Ammoglobigerina globigeriniformis (Parker } \\
\text { and Jones) }\end{array}$ & $\begin{array}{c}\text { Alboran } \\
\text { Oran } \\
\text { Mallorca }\end{array}$ & $\begin{array}{l}0 \\
0 \\
0\end{array}$ & & $\begin{array}{c}60-83 \\
48-73 ; 118-130 \\
40-80\end{array}$ & & & & \\
\hline Ammolagena clavata (Parker and Jones) & Mallorca & (o) & & $94-235$ & & & & \\
\hline
\end{tabular}


TABLE 2 (continued).

\begin{tabular}{|c|c|c|c|c|c|c|c|c|}
\hline Ammonia beccarii (Linné) & $\begin{array}{c}\text { Alboran } \\
\text { Oran } \\
\text { Mallorca }\end{array}$ & $\begin{array}{l}* \\
* \\
*\end{array}$ & $\begin{array}{l}20-83 \\
40-56\end{array}$ & $\begin{array}{l}97-115 \\
20-127 \\
40-235\end{array}$ & & & & 0 \\
\hline Ammonia parkinsonia (d'Orbigny) & $\begin{array}{c}\text { Alboran } \\
\text { Oran } \\
\text { Mallorca }\end{array}$ & $\begin{array}{l}* \\
* \\
*\end{array}$ & & & & & & 0 \\
\hline Ammosphaeroidina sphaeroidinoides (Brady) & Mallorca & (o) & & $94-235$ & & & & \\
\hline Amphicoryna scalaris (Batsch) & $\begin{array}{c}\text { Alboran } \\
\text { Oran } \\
\text { Mallorca }\end{array}$ & $\begin{array}{c}0 \\
0 \\
00\end{array}$ & $\begin{array}{c}130 \\
105-161\end{array}$ & $\begin{array}{c}60-91 \\
48-130 \\
80-235\end{array}$ & $\begin{array}{l}\circ \\
\circ\end{array}$ & 0 & & \\
\hline Angulogerina angulosa (Williamson) & $\begin{array}{c}\text { Alboran } \\
\text { Oran } \\
\text { Mallorca }\end{array}$ & $\begin{array}{l}00 \\
00 \\
00\end{array}$ & & $\begin{array}{l}38-161 \\
67-130 \\
80-235\end{array}$ & $\begin{array}{c}0 \\
00 \\
0\end{array}$ & $\begin{array}{c}0 \\
00 \\
0\end{array}$ & $\begin{array}{l}0 \\
0\end{array}$ & \\
\hline Anomalinoides sp. 1 & $\begin{array}{c}\text { Alboran } \\
\text { Oran } \\
\text { Mallorca }\end{array}$ & $\begin{array}{l}\text { oo } \\
\text { oo } \\
\text { oo }\end{array}$ & & $\begin{array}{l}38-161 \\
48-121 \\
47-163\end{array}$ & $\begin{array}{l}0 \\
0 \\
0\end{array}$ & $\begin{array}{l}0 \\
0 \\
0\end{array}$ & $\begin{array}{l}0 \\
0\end{array}$ & \\
\hline Articulina mucronata (d’Orbigny) & Mallorca & 0 & & $40-80$ & 0 & 0 & 0 & \\
\hline Asterigerinata adriatica Haake & Mallorca & ** & & & 0 & O० & 0 & \\
\hline Asterigerinata mamilla (Williamson) & $\begin{array}{c}\text { Alboran } \\
\text { Oran } \\
\text { Mallorca }\end{array}$ & $\begin{array}{c}0000 \\
00 \\
0000\end{array}$ & $\begin{array}{l}48-73 \\
40-48\end{array}$ & $\begin{array}{l}38-161 \\
20-127 \\
40-235\end{array}$ & $\begin{array}{c}0000 \\
0000 \\
00\end{array}$ & $\begin{array}{c}0000 \\
0000 \\
00\end{array}$ & $\begin{array}{c}0000 \\
00\end{array}$ & oo \\
\hline Asterigerinata mariae Sgarrella & $\begin{array}{c}\text { Alboran } \\
\text { Oran } \\
\text { Mallorca }\end{array}$ & $\begin{array}{l}* * \\
* * \\
* *\end{array}$ & & & $\begin{array}{c}0 \\
0 \\
00\end{array}$ & $\begin{array}{c}0 \\
0 \\
00\end{array}$ & $\begin{array}{l}0 \\
00\end{array}$ & \\
\hline Astrononion stelligerum (d'Orbigny) & $\begin{array}{c}\text { Alboran } \\
\text { Oran } \\
\text { Mallorca }\end{array}$ & $\begin{array}{c}00 \\
\text { oo } \\
0\end{array}$ & & $\begin{array}{c}53-83 \\
48-115 \\
47-80\end{array}$ & $\begin{array}{c}0 \\
\text { oo }\end{array}$ & $\begin{array}{l}0 \\
0\end{array}$ & ○ & oo \\
\hline Bigenerina nodosaria d'Orbigny & $\begin{array}{c}\text { Oran } \\
\text { Mallorca }\end{array}$ & $\begin{array}{l}00 \\
\text { o० }\end{array}$ & $94 ; 235$ & $\begin{array}{l}84-127 \\
94-163\end{array}$ & 0 & o & & \\
\hline Biloculinella globula (Bornemann) & $\begin{array}{c}\text { Alboran } \\
\text { Oran } \\
\text { Mallorca }\end{array}$ & $\begin{array}{l}0 \\
0 \\
0\end{array}$ & & $\begin{array}{c}64-161 \\
48-127 \\
40 ; 74-235\end{array}$ & 0 & 0 & & \\
\hline Biloculinella inflata (Wright) & Mallorca & & & & (o) & & & \\
\hline Biloculinella labiata (Schlumberger) & $\begin{array}{c}\text { Alboran } \\
\text { Oran } \\
\text { Mallorca }\end{array}$ & $\begin{array}{l}0 \\
0 \\
0\end{array}$ & & $\begin{array}{l}83-115 \\
70-100 \\
67-163\end{array}$ & o & & & \\
\hline Bolivina cistina Cushman & $\begin{array}{c}\text { Oran } \\
\text { Alboran } \\
\text { Mallorca }\end{array}$ & $\begin{array}{l}0 \\
0 \\
0\end{array}$ & & $\begin{array}{c}70-130 \\
115 \\
61\end{array}$ & 0 & & o & \\
\hline Bolivina plicatella Cushman & $\begin{array}{c}\text { Alboran } \\
\text { Oran } \\
\text { Mallorca }\end{array}$ & $\begin{array}{l}0 \\
0 \\
0\end{array}$ & & $\begin{array}{c}60-91 \\
48 \\
94-235\end{array}$ & 0 & $\begin{array}{l}0 \\
0\end{array}$ & 0 & \\
\hline $\begin{array}{l}\text { Bolivina pseudoplicata Heron-Allen and } \\
\text { Earland }\end{array}$ & Oran & & & & (o) & & & \\
\hline Bolivina subspinescens Cushman & $\begin{array}{c}\text { Alboran } \\
\text { Oran } \\
\text { Mallorca }\end{array}$ & $\begin{array}{l}0 \\
0 \\
0\end{array}$ & & $\begin{array}{c}60 \\
73-130 \\
94-163\end{array}$ & & & & \\
\hline
\end{tabular}


MILKER \& SCHMIEDL: TAXONOMY FORAMINIFERA

TABLE 2 (continued).

\begin{tabular}{|c|c|c|c|c|c|c|c|c|}
\hline Bolivina variabilis (Williamson) & $\begin{array}{c}\text { Alboran } \\
\text { Oran } \\
\text { Mallorca }\end{array}$ & $\begin{array}{c}0 \\
0 \\
00\end{array}$ & & \begin{tabular}{|c|}
$38-60 ; 115$ \\
$48-70 ; 118-127$ \\
$48-235$
\end{tabular} & $\begin{array}{l}0 \\
\text { oo }\end{array}$ & 0 & $\begin{array}{l}0 \\
0\end{array}$ & \\
\hline Bolivina sp. 1 & Oran & 0 & 73 & $48-127$ & & & & \\
\hline Brizalina difformis (Williamson) & $\begin{array}{c}\text { Alboran } \\
\text { Oran } \\
\text { Mallorca }\end{array}$ & $\begin{array}{l}00 \\
\text { oo } \\
\text { oo }\end{array}$ & $60 ; 86$ & \begin{tabular}{|c|}
$53-161$ \\
$70-130$ \\
$48-235 ; 67-235$
\end{tabular} & & & & \\
\hline Brizalina dilatata (Reuss) & $\begin{array}{c}\text { Oran } \\
\text { Mallorca }\end{array}$ & $\begin{array}{l}0 \\
0\end{array}$ & $\begin{array}{l}20 ; 67- \\
118 \\
94\end{array}$ & $\begin{array}{c}\text { 67-118 } \\
105\end{array}$ & & & & \\
\hline Brizalina spathulata (Williamson) & $\begin{array}{c}\text { Alboran } \\
\text { Oran } \\
\text { Mallorca }\end{array}$ & $\begin{array}{c}0 \\
\text { oo } \\
\text { o० }\end{array}$ & 118 & \begin{tabular}{|c|}
$38-91$ \\
$70-130 ; 100-130$ \\
$47-235 ; 105-235$
\end{tabular} & $\begin{array}{l}0 \\
0\end{array}$ & 0 & & \\
\hline Brizalina striatula (Cushman) & $\begin{array}{c}\text { Alboran } \\
\text { Oran } \\
\text { Mallorca }\end{array}$ & $\begin{array}{c}0 \\
\text { oo } \\
0\end{array}$ & $\begin{array}{l}91-115 \\
70-127\end{array}$ & $\begin{array}{c}115 \\
67-130 \\
94-235\end{array}$ & $\begin{array}{l}0 \\
0\end{array}$ & 0 & & \\
\hline Brizalina sp. 1 & $\begin{array}{c}\text { Alboran } \\
\text { Oran } \\
\text { Mallorca }\end{array}$ & & & & $\begin{array}{c}0 \\
\text { (o) }\end{array}$ & $\begin{array}{l}0 \\
\text { (o) }\end{array}$ & o & \\
\hline Buccella granulata (Di Napoli Alliata) & $\begin{array}{c}\text { Alboran } \\
\text { Oran } \\
\text { Mallorca }\end{array}$ & $\begin{array}{l}0 \\
0 \\
0\end{array}$ & & $\begin{array}{c}60-86 \\
20-127 \\
40-67\end{array}$ & $\begin{array}{l}0 \\
0\end{array}$ & 0 & & \\
\hline Bulimina aculeata d'Orbigny & $\begin{array}{c}\text { Oran } \\
\text { Mallorca }\end{array}$ & $\begin{array}{l}\text { O० } \\
\text { o० }\end{array}$ & $\begin{array}{l}67-121 \\
105-235\end{array}$ & $\begin{array}{l}\text { 48-130 } \\
61-235\end{array}$ & $\begin{array}{l}0 \\
0\end{array}$ & $\begin{array}{c}0 \\
\text { oo }\end{array}$ & 0 & \\
\hline Bulimina costata d'Orbigny & $\begin{array}{l}\text { Alboran } \\
\text { Mallorca }\end{array}$ & $\begin{array}{l}0 \\
0\end{array}$ & $80-163$ & \begin{tabular}{c|}
$91-161$ \\
$94-235 ; \mathbf{1 6 3 - 2 3 5}$
\end{tabular} & & & & \\
\hline Bulimina elongata d'Orbigny & $\begin{array}{c}\text { Alboran } \\
\text { Oran } \\
\text { Mallorca }\end{array}$ & $\begin{array}{c}00 \\
00 \\
000\end{array}$ & $\begin{array}{l}67-130 \\
94-163\end{array}$ & $\begin{array}{c}53-69 \\
48-127 \\
74-235\end{array}$ & 0 & oo & 0 & \\
\hline Bulimina gibba Fornasini & $\begin{array}{c}\text { Alboran } \\
\text { Oran } \\
\text { Mallorca }\end{array}$ & $\begin{array}{c}0 \\
\text { oo } \\
\text { o० }\end{array}$ & $\begin{array}{c}67-121 \\
116\end{array}$ & $\begin{array}{c}63-97 \\
67-130 \\
94-235\end{array}$ & 0 & o & & \\
\hline Bulimina marginata d'Orbigny & $\begin{array}{c}\text { Alboran } \\
\text { Oran } \\
\text { Mallorca }\end{array}$ & $\begin{array}{c}0 \\
0 \\
00\end{array}$ & $\begin{array}{l}94 \\
67\end{array}$ & $\begin{array}{c}83-91 \\
118-127 \\
94-235 ; 163-235\end{array}$ & 0 & & & \\
\hline Cancris auriculus (Fichtel and Moll) & $\begin{array}{c}\text { Alboran } \\
\text { Oran } \\
\text { Mallorca }\end{array}$ & $\begin{array}{l}00 \\
\text { oo } \\
\text { o० }\end{array}$ & $\begin{array}{c}48-130 \\
80-94\end{array}$ & $\begin{array}{c}60-115 \\
48-127 \\
94\end{array}$ & $\begin{array}{l}\circ \\
0\end{array}$ & $\begin{array}{l}0 \\
0\end{array}$ & & \\
\hline Cassidulina laevigata s.I. d'Orbigny & $\begin{array}{c}\text { Alboran } \\
\text { Oran } \\
\text { Mallorca }\end{array}$ & $\begin{array}{c}0 \\
0000 \\
0000\end{array}$ & $\begin{array}{c}97 \\
94-116\end{array}$ & \begin{tabular}{|c|}
$53-161$ \\
$20-130 ; 84-118$ \\
$40-235 ; 80-163$
\end{tabular} & $\begin{array}{c}0 \\
0 \\
0000\end{array}$ & $\begin{array}{c}0 \\
000\end{array}$ & 0 & \\
\hline Cassidulina obtusa Williamson & $\begin{array}{c}\text { Alboran } \\
\text { Oran } \\
\text { Mallorca }\end{array}$ & $\begin{array}{c}0000 \\
00 \\
00\end{array}$ & $\begin{array}{l}60-161 \\
73-121 \\
94-163\end{array}$ & \begin{tabular}{|c|}
$38-161 ; 83-115$ \\
$70-130$ \\
$56-235$
\end{tabular} & $\begin{array}{c}000 \\
00 \\
0\end{array}$ & $\begin{array}{c}00 \\
0 \\
0\end{array}$ & 00 & 0 \\
\hline Cassidulinid sp. 1 & Oran & & & & & (o) & & \\
\hline Cassidulinoides bradyi (Norman) & $\begin{array}{c}\text { Alboran } \\
\text { Oran } \\
\text { Mallorca }\end{array}$ & $\begin{array}{l}0 \\
0 \\
0\end{array}$ & $\begin{array}{l}121 \\
94\end{array}$ & $\begin{array}{c}102 \\
70 ; 121-130 \\
94\end{array}$ & & & & \\
\hline
\end{tabular}


TABLE 2 (continued).

\begin{tabular}{|c|c|c|c|c|c|c|c|c|}
\hline Cibicidella variablis (d’Orbigny) & $\begin{array}{c}\text { Alboran } \\
\text { Oran } \\
\text { Mallorca }\end{array}$ & $\begin{array}{l}0 \\
0 \\
0\end{array}$ & 48 & $\begin{array}{c}38-115 \\
48-100 \\
56-61\end{array}$ & $\begin{array}{l}0 \\
0 \\
0\end{array}$ & $\begin{array}{l}0 \\
0 \\
0\end{array}$ & $\begin{array}{l}0 \\
0\end{array}$ & 0 \\
\hline Cibicides cf. mayori (Cushman) & $\begin{array}{c}\text { Alboran } \\
\text { Oran } \\
\text { Mallorca }\end{array}$ & $\begin{array}{c}000 \\
00 \\
00\end{array}$ & & $\begin{array}{l}38-115 \\
48-121 \\
48-163\end{array}$ & $\begin{array}{c}00 \\
00 \\
0\end{array}$ & $\begin{array}{c}00 \\
00 \\
0\end{array}$ & $\begin{array}{c}00 \\
0\end{array}$ & O० \\
\hline Cibicides pseudolobatulus Perelis and Reiss & $\begin{array}{c}\text { Alboran } \\
\text { Oran } \\
\text { Mallorca }\end{array}$ & $\begin{array}{l}00 \\
00 \\
00\end{array}$ & $\begin{array}{c}91 \\
48 ; 121 \\
94\end{array}$ & $\begin{array}{l}38-161 \\
20-130 \\
40-161\end{array}$ & $\begin{array}{l}00 \\
00 \\
00\end{array}$ & $\begin{array}{c}00 \\
0 \\
00\end{array}$ & $\begin{array}{c}000 \\
00\end{array}$ & 00 \\
\hline Cibicides refulgens Montfort & $\begin{array}{c}\text { Alboran } \\
\text { Oran } \\
\text { Mallorca }\end{array}$ & $\begin{array}{l}00 \\
00 \\
00\end{array}$ & 73 & $\begin{array}{c}38-115 ; 161 \\
48-130 \\
40-163\end{array}$ & o & $\begin{array}{c}00 \\
00 \\
0\end{array}$ & oo & 00 \\
\hline Cibicidoides pseudoungerianus (Cushman) & $\begin{array}{c}\text { Alboran } \\
\text { Oran } \\
\text { Mallorca }\end{array}$ & $\begin{array}{c}0000 \\
000 \\
00\end{array}$ & & $\begin{array}{l}38-161 \\
20-130 \\
40-235\end{array}$ & $\begin{array}{c}0000 \\
0 \\
0\end{array}$ & $\begin{array}{c}000 \\
0 \\
0\end{array}$ & o & 0 \\
\hline Clavulina cylindrica (Cushman) & $\begin{array}{c}\text { Oran } \\
\text { Mallorca }\end{array}$ & 0 & 127 & 73,127 & 0 & 0 & 0 & \\
\hline Conorbella pulvinata (Brady) & Mallorca & & & & & & 0 & \\
\hline Cornuspira foliacea (Philippi) & $\begin{array}{l}\text { Alboran } \\
\text { Mallorca }\end{array}$ & 0 & & 83 & 0 & $\begin{array}{l}0 \\
0\end{array}$ & & \\
\hline Cornuspira involvens (Reuss) & $\begin{array}{c}\text { Alboran } \\
\text { Oran } \\
\text { Mallorca }\end{array}$ & $\begin{array}{c}0 \\
0 \\
00\end{array}$ & 74 & $\begin{array}{c}63-91 \\
97 \\
61-235\end{array}$ & $\begin{array}{c}0 \\
0 \\
00\end{array}$ & $\begin{array}{c}0 \\
0 \\
00\end{array}$ & 0 & \\
\hline Cribrostomoides jeffreysii (Williamson) & $\begin{array}{c}\text { Alboran } \\
\text { Oran } \\
\text { Mallorca }\end{array}$ & $\begin{array}{l}0 \\
0 \\
0\end{array}$ & $\begin{array}{c}67-83 \\
116\end{array}$ & $\begin{array}{c}53-161 \\
48-121 \\
163\end{array}$ & & & & \\
\hline Cycloforina contorta (d'Orbigny) & $\begin{array}{c}\text { Alboran } \\
\text { Oran } \\
\text { Mallorca }\end{array}$ & $\begin{array}{l}0 \\
0 \\
0\end{array}$ & & $\begin{array}{c}38-115 \\
97 \\
40-235\end{array}$ & 0 & & o & \\
\hline Cycloforina? tenuicollis (Wiesner) & $\begin{array}{c}\text { Alboran } \\
\text { Oran } \\
\text { Mallorca }\end{array}$ & $\begin{array}{c}0 \\
00 \\
0\end{array}$ & & $\begin{array}{c}97 \\
84-127 \\
56-94\end{array}$ & 0 & 0 & 0 & \\
\hline $\begin{array}{l}\text { Cycloforina villafranca (Le Calvez and Le } \\
\text { Calvez) }\end{array}$ & $\begin{array}{c}\text { Oran } \\
\text { Mallorca }\end{array}$ & $\begin{array}{l}00 \\
00\end{array}$ & & $\begin{array}{c}48-73 ; 127 \\
40-94\end{array}$ & 0 & 0 & 0 & \\
\hline Cycloforina sp. 1 & $\begin{array}{c}\text { Alboran } \\
\text { Oran } \\
\text { Mallorca }\end{array}$ & $\begin{array}{l}0 \\
0 \\
0\end{array}$ & & $\begin{array}{c}38 ; 115 \\
97 \\
40-235\end{array}$ & & & (o) & \\
\hline Cycloforina? sp.2 & Oran & & & & & 0 & & \\
\hline Cymbaloporetta bulloides (d'Orbigny) & Mallorca & & & & & & (o) & \\
\hline Dentalina guttifera d'Orbigny & Mallorca & 0 & 80 & & & & & \\
\hline $\begin{array}{l}\text { Deuterammina dublinensis Broennimann and } \\
\text { Whittaker }\end{array}$ & $\begin{array}{c}\text { Alboran } \\
\text { Oran } \\
\text { Mallorca }\end{array}$ & $\begin{array}{l}0 \\
0 \\
0\end{array}$ & $97-127$ & $\begin{array}{c}60-86 \\
48-130 \\
48\end{array}$ & & & & \\
\hline Discanomalina semipunctata (Bailey) & Alboran & 0 & & $91-161$ & & & & \\
\hline Discorbinella bertheloti (d'Orbigny) & $\begin{array}{c}\text { Alboran } \\
\text { Oran } \\
\text { Mallorca }\end{array}$ & $\begin{array}{c}00 \\
000 \\
00\end{array}$ & $\begin{array}{c}86 \\
48-127 \\
235\end{array}$ & $\begin{array}{l}38-115 \\
48-130 \\
67-235\end{array}$ & $\begin{array}{c}0 \\
00 \\
0\end{array}$ & $\begin{array}{c}0 \\
00 \\
0\end{array}$ & 0 & \\
\hline Discorbinoides sp. 1 & $\begin{array}{c}\text { Alboran } \\
\text { Oran }\end{array}$ & & & & 0 & $\begin{array}{l}0 \\
\text { (o) }\end{array}$ & o & \\
\hline
\end{tabular}




\section{MILKER \& SCHMIEDL: TAXONOMY FORAMINIFERA}

TABLE 2 (continued).

\begin{tabular}{|c|c|c|c|c|c|c|c|c|}
\hline Discorbinoides? sp. 2 & $\begin{array}{c}\text { Alboran } \\
\text { Oran } \\
\text { Mallorca }\end{array}$ & $\begin{array}{l}0 \\
0 \\
0\end{array}$ & & $\begin{array}{c}161 \\
100-118 \\
47-105\end{array}$ & o & $\begin{array}{l}0 \\
0\end{array}$ & 0 & \\
\hline Discorbis williamsoni Chapman and Parr & $\begin{array}{c}\text { Alboran } \\
\text { Oran } \\
\text { Mallorca }\end{array}$ & $\begin{array}{l}0 \\
0 \\
0\end{array}$ & & $\begin{array}{c}38-91 \\
100 \\
40-80 ; 235\end{array}$ & $\begin{array}{l}0 \\
0 \\
0\end{array}$ & $\begin{array}{c}00 \\
0 \\
0\end{array}$ & $\begin{array}{l}0 \\
0\end{array}$ & \\
\hline Eggerelloides scabrus (Williamson) & $\begin{array}{c}\text { Oran } \\
\text { Mallorca }\end{array}$ & $\begin{array}{l}0 \\
\end{array}$ & $\begin{array}{l}67 \\
94\end{array}$ & $\begin{array}{l}20 \\
40\end{array}$ & & & & \\
\hline Elphidium aculeatum (d'Orbigny) & $\begin{array}{l}\text { Alboran } \\
\text { Mallorca }\end{array}$ & $\begin{array}{c}00 \\
0\end{array}$ & & $\begin{array}{c}38-97 \\
48\end{array}$ & 0 & $\begin{array}{l}0 \\
0\end{array}$ & $\begin{array}{c}00 \\
0\end{array}$ & oo \\
\hline Elphidium advenum (Cushman) & $\begin{array}{c}\text { Alboran } \\
\text { Oran } \\
\text { Mallorca }\end{array}$ & $\begin{array}{l}\text { ০o } \\
\text { oo }\end{array}$ & & $\begin{array}{c}67 ; 83,121 \\
40-94\end{array}$ & o & $\begin{array}{l}0 \\
0\end{array}$ & 0 & oo \\
\hline Elphidium complanatum (d'Orbigny) & $\begin{array}{c}\text { Alboran } \\
\text { Oran } \\
\text { Mallorca }\end{array}$ & $\begin{array}{c}0000 \\
00 \\
00\end{array}$ & & $\begin{array}{l}38-161 \\
48-130 \\
47-163\end{array}$ & $\begin{array}{l}00 \\
00 \\
00\end{array}$ & $\begin{array}{c}0000 \\
00 \\
00\end{array}$ & $\begin{array}{l}000 \\
00\end{array}$ & o० \\
\hline $\begin{array}{l}\text { Elphidium complanatum (d'Orbigny) var. } \\
\text { tyrrhenianum Accordi }\end{array}$ & $\begin{array}{c}\text { Alboran } \\
\text { Oran } \\
\text { Mallorca }\end{array}$ & $\begin{array}{l}0 \\
0 \\
0\end{array}$ & & $\begin{array}{c}86 \\
48-121 \\
48-235\end{array}$ & 0 & 0 & o & 000 \\
\hline Elphidium crispum (Linné) & $\begin{array}{c}\text { Alboran } \\
\text { Oran } \\
\text { Mallorca }\end{array}$ & $\begin{array}{l}00 \\
00 \\
00\end{array}$ & $\begin{array}{l}67 \\
67\end{array}$ & $\begin{array}{c}38-161 \\
20 ; 48-127 \\
40-94\end{array}$ & 0 & 0 & o & oo \\
\hline Elphidium decipiens (Costa) & $\begin{array}{c}\text { Oran } \\
\text { Mallorca }\end{array}$ & $\begin{array}{c}0 \\
00\end{array}$ & & $\begin{array}{c}100 \\
67-116\end{array}$ & 0 & $\begin{array}{l}0 \\
0\end{array}$ & 0 & \\
\hline Elphidium granosum (d'Orbigny) & $\begin{array}{c}\text { Oran } \\
\text { Mallorca }\end{array}$ & $\begin{array}{l}0 \\
0\end{array}$ & $\begin{array}{l}118 \\
116\end{array}$ & $\begin{array}{c}83 \\
48-235\end{array}$ & o & o & o & \\
\hline Elphidium incertum (Williamson) & $\begin{array}{c}\text { Oran } \\
\text { Mallorca }\end{array}$ & $\begin{array}{l}0 \\
0\end{array}$ & & $\begin{array}{c}127 \\
47-163\end{array}$ & 0 & 0 & o & \\
\hline Elphidium macellum (Fichtel and Moll) & $\begin{array}{l}\text { Alboran } \\
\text { Mallorca }\end{array}$ & $\begin{array}{c}0 \\
00\end{array}$ & $\begin{array}{l}86 \\
94\end{array}$ & $\begin{array}{c}38 ; 73-105 \\
67-80\end{array}$ & 0 & $\begin{array}{l}0 \\
0\end{array}$ & o & \\
\hline Elphidium margaritaceum (Cushman) & Mallorca & 0 & & $40-47$ & & & o & \\
\hline Elphidium sp. 1 & Alboran & & & & 0 & 00 & 000 & 0000 \\
\hline Eponides concameratus (Williamson) & $\begin{array}{c}\text { Alboran } \\
\text { Oran } \\
\text { Mallorca }\end{array}$ & $\begin{array}{c}00 \\
000 \\
0\end{array}$ & $\begin{array}{l}85 \\
67\end{array}$ & $\begin{array}{c}38-161 \\
48-130 ; 64-85 \\
67-94\end{array}$ & $\begin{array}{c}00 \\
0\end{array}$ & $\begin{array}{l}0 \\
0\end{array}$ & 0 & \\
\hline Eponides sp. 1 & $\begin{array}{c}\text { Alboran } \\
\text { Oran } \\
\text { Mallorca }\end{array}$ & $\begin{array}{l}0 \\
0 \\
0\end{array}$ & $56-74$ & $\begin{array}{c}38 \\
48-73 \\
40-80\end{array}$ & & 0 & & \\
\hline Favulina foveolata (Seguenza) & $\begin{array}{c}\text { Alboran } \\
\text { Oran } \\
\text { Mallorca }\end{array}$ & $\begin{array}{l}0 \\
0\end{array}$ & & $\begin{array}{c}115-130 \\
94\end{array}$ & o & o & & \\
\hline Favulina hexagona (Williamson) & $\begin{array}{c}\text { Alboran } \\
\text { Oran } \\
\text { Mallorca }\end{array}$ & $\begin{array}{c}00 \\
0 \\
0\end{array}$ & & $\begin{array}{c}53-115 \\
67-130 \\
48 ; 94-235\end{array}$ & $\begin{array}{l}0 \\
0 \\
0\end{array}$ & $\begin{array}{l}0 \\
0\end{array}$ & 0 & \\
\hline Fissurina castanea (Flint) & Oran & 0 & & $90-130$ & & & & \\
\hline Fissurina crebra (Matthes) & $\begin{array}{c}\text { Alboran } \\
\text { Oran } \\
\text { Mallorca }\end{array}$ & $\begin{array}{l}0 \\
0 \\
0\end{array}$ & 90 & $\begin{array}{c}69-115 \\
70-90 \\
47-94\end{array}$ & & & & \\
\hline
\end{tabular}


TABLE 2 (continued).

\begin{tabular}{|c|c|c|c|c|c|c|c|c|}
\hline Fissurina fasciata (Egger) & $\begin{array}{c}\text { Alboran } \\
\text { Oran } \\
\text { Mallorca }\end{array}$ & $\begin{array}{l}0 \\
0 \\
0\end{array}$ & 73 & $\begin{array}{c}63-69 \\
83-130 \\
61-80\end{array}$ & $\mathrm{o}$ & & & \\
\hline Fissurina lacunata (Burrows and Holland) & Alboran & & & & (o) & (o) & (o) & \\
\hline Fissurina marginata (Montagu) & $\begin{array}{c}\text { Alboran } \\
\text { Oran } \\
\text { Mallorca }\end{array}$ & $\begin{array}{l}0 \\
0 \\
0\end{array}$ & 70 & $\begin{array}{c}73-161 \\
70-100 \\
47-94\end{array}$ & 0 & & & \\
\hline Fissurina orbignyana Seguenza & $\begin{array}{c}\text { Alboran } \\
\text { Oran } \\
\text { Mallorca }\end{array}$ & $\begin{array}{l}\text { oo } \\
\text { oo } \\
\text { oo }\end{array}$ & & $\begin{array}{l}60-115 \\
48-130 \\
47 ; 163\end{array}$ & & & & \\
\hline Floresina sp. 1 & $\begin{array}{c}\text { Oran } \\
\text { Mallorca }\end{array}$ & & & & $\begin{array}{l}\text { (o) } \\
\text { (o) }\end{array}$ & $\begin{array}{l}\text { (o) } \\
\text { (o) }\end{array}$ & (o) & \\
\hline Fursenkoina acuta (d'Orbigny) & $\begin{array}{c}\text { Alboran } \\
\text { Oran }\end{array}$ & $\begin{array}{l}0 \\
0\end{array}$ & 20 & 115 & & & & \\
\hline Gaudryina rudis Wright & $\begin{array}{c}\text { Alboran } \\
\text { Oran } \\
\text { Mallorca }\end{array}$ & $\begin{array}{c}00 \\
000 \\
0\end{array}$ & 48,80 & $\begin{array}{l}38-161 \\
48-130 \\
40-163\end{array}$ & 0 & $\begin{array}{l}0 \\
0\end{array}$ & & \\
\hline Gaudryina siciliana Cushman & $\begin{array}{c}\text { Alboran } \\
\text { Oran } \\
\text { Mallorca }\end{array}$ & $\begin{array}{c}0 \\
\text { oo } \\
\text { oo }\end{array}$ & 56 & $\begin{array}{l}63-161 \\
48-130 \\
47-105\end{array}$ & $\begin{array}{l}0 \\
0\end{array}$ & $\begin{array}{l}0 \\
0\end{array}$ & 0 & \\
\hline $\begin{array}{l}\text { Gavelinopsis praegeri (Heron Allen and } \\
\text { Earland) }\end{array}$ & $\begin{array}{c}\text { Alboran } \\
\text { Oran } \\
\text { Mallorca }\end{array}$ & $\begin{array}{l}000 \\
000 \\
000\end{array}$ & $\begin{array}{c}60 \\
100-130\end{array}$ & $\begin{array}{l}38-161 \\
48-130 \\
47-235\end{array}$ & $\begin{array}{l}00 \\
00 \\
00\end{array}$ & $\begin{array}{l}00 \\
00 \\
00\end{array}$ & $\begin{array}{c}0 \\
\text { oo }\end{array}$ & \\
\hline Glabratella erecta (Sidebottom) & $\begin{array}{c}\text { Alboran } \\
\text { Oran } \\
\text { Mallorca }\end{array}$ & $\begin{array}{l}0 \\
0 \\
0\end{array}$ & & $\begin{array}{c}53-69 \\
67-127 \\
47-235\end{array}$ & o & o & 0 & $\mathrm{o}$ \\
\hline $\begin{array}{l}\text { Glabratella hexacamerata Seigle and } \\
\text { Bermudez }\end{array}$ & $\begin{array}{c}\text { Alboran } \\
\text { Oran } \\
\text { Mallorca }\end{array}$ & $\begin{array}{l}0 \\
0\end{array}$ & & $\begin{array}{c}69 \\
48-118\end{array}$ & 0 & o & ০o & \\
\hline Glabratella patelliformis (Brady) & $\begin{array}{l}\text { Alboran } \\
\text { Mallorca }\end{array}$ & & & & o & $\begin{array}{l}0 \\
0\end{array}$ & $\begin{array}{l}0 \\
0\end{array}$ & \\
\hline Glaphyrammina americana (Cushman) & Oran & o & 84 & $48,90-130$ & & & & \\
\hline Globobulimina affinis (d'Orbigny) & Oran & o & $100-130$ & $115-130$ & & & & \\
\hline Globocassidulina oblonga (Reuss) & $\begin{array}{c}\text { Alboran } \\
\text { Oran } \\
\text { Mallorca }\end{array}$ & $\begin{array}{c}00 \\
000 \\
00\end{array}$ & $73-130$ & $\begin{array}{l}53-115 \\
48-130 \\
56-235\end{array}$ & $\begin{array}{l}00 \\
00 \\
00\end{array}$ & $\begin{array}{l}0 \\
0 \\
0\end{array}$ & & \\
\hline Globocassidulina subglobosa (Brady) & $\begin{array}{c}\text { Alboran } \\
\text { Oran } \\
\text { Mallorca }\end{array}$ & $\begin{array}{c}0000 \\
0000 \\
00\end{array}$ & $\begin{array}{c}60 \\
70-130\end{array}$ & $\begin{array}{c}38-161 ; \mathbf{9 1 - 1 1 5} \\
48-130 ; 90-100 \\
67-235\end{array}$ & $\begin{array}{c}0000 \\
00 \\
00\end{array}$ & $\begin{array}{l}00 \\
00 \\
\text { oo }\end{array}$ & 00 & \\
\hline $\begin{array}{l}\text { Globulina gibba (d'Orbigny) var. punctata } \\
\text { (d'Orbigny) }\end{array}$ & Alboran & 0 & & 86 & & & & \\
\hline Globulina myristiformis (Williamson) & $\begin{array}{c}\text { Alboran } \\
\text { Oran }\end{array}$ & $\begin{array}{c}0 \\
\text { oo }\end{array}$ & & $\begin{array}{c}63 \\
73-121\end{array}$ & & & & \\
\hline Gyroidinoides soldanii (d'Orbigny) & Mallorca & o० & & $94-235$ & & & & \\
\hline Gyroidinoides umbonata (Silvestri) & $\begin{array}{c}\text { Alboran } \\
\text { Oran } \\
\text { Mallorca }\end{array}$ & $\begin{array}{l}0 \\
0 \\
0\end{array}$ & & $\begin{array}{c}115 \\
127 \\
67-116\end{array}$ & 0 & o & & \\
\hline
\end{tabular}




\section{MILKER \& SCHMIEDL: TAXONOMY FORAMINIFERA}

TABLE 2 (continued).

\begin{tabular}{|c|c|c|c|c|c|c|c|c|}
\hline Haplophragmoides? sp. 1 & Oran & 0 & 100 & & & & & \\
\hline Haynesina depressula (Walker and Jacob) & $\begin{array}{c}\text { Oran } \\
\text { Mallorca }\end{array}$ & 0 & & $94-235$ & 0 & $\begin{array}{l}0 \\
\\
0\end{array}$ & 0 & \\
\hline Haynesina simplex (Cushman) & $\begin{array}{c}\text { Alboran } \\
\text { Oran } \\
\text { Mallorca }\end{array}$ & $\begin{array}{c}0 \\
0 \\
00\end{array}$ & & $\begin{array}{c}63-97 \\
70-84 \\
40-235\end{array}$ & oo & $\begin{array}{l}\circ \\
\circ\end{array}$ & oo & \\
\hline Haynesina sp. 1 & Mallorca & & & & 0 & 0 & 0 & \\
\hline Hemirobulina sp.1 & $\begin{array}{l}\text { Alboran } \\
\text { Mallorca }\end{array}$ & $\begin{array}{l}0 \\
0\end{array}$ & & $\begin{array}{c}83-86 \\
94-105\end{array}$ & & & & \\
\hline Heronallenia lingulata (Burrows and Holland) & $\begin{array}{c}\text { Alboran } \\
\text { Oran } \\
\text { Mallorca }\end{array}$ & $\begin{array}{l}0 \\
0 \\
0\end{array}$ & & $\begin{array}{l}60-115 \\
90-130 \\
67-105\end{array}$ & 0 & 0 & & \\
\hline Hoeglundina elegans (d'Orbigny) & $\begin{array}{c}\text { Alboran } \\
\text { Oran } \\
\text { Mallorca }\end{array}$ & $\begin{array}{l}0 \\
0 \\
0\end{array}$ & $105-163$ & $\begin{array}{c}121 \\
67-127 \\
94-235\end{array}$ & & & & \\
\hline Hyalinea balthica (Schroeter) & $\begin{array}{c}\text { Oran } \\
\text { Mallorca }\end{array}$ & $\begin{array}{c}0 \\
000\end{array}$ & $\begin{array}{l}47 ; 116- \\
235\end{array}$ & $\begin{array}{c}127 \\
94-235\end{array}$ & 0 & 0 & & \\
\hline Hyalinonetrion gracillimum (Costa) & $\begin{array}{c}\text { Oran } \\
\text { Mallorca }\end{array}$ & o & 90 & & 0 & & & \\
\hline Labrospira subglobosa (Sars) & Oran & 0 & 127 & & & & & \\
\hline $\begin{array}{l}\text { Lachlanella bicornis ((Walker and Jacob) } \\
\text { emend. Haynes) }\end{array}$ & $\begin{array}{c}\text { Alboran } \\
\text { Oran }\end{array}$ & $\begin{array}{ll}0 \\
\end{array}$ & & $\begin{array}{c}86 \\
100\end{array}$ & 0 & & & o \\
\hline Lachlanella bradyana (Cushman) & $\begin{array}{c}\text { Alboran } \\
\text { Oran } \\
\text { Mallorca }\end{array}$ & $\begin{array}{l}0 \\
0 \\
0\end{array}$ & & $\begin{array}{l}38-102 \\
78-100 \\
47-116\end{array}$ & o & o & o & \\
\hline Lachlanella carinata (d’Orbigny) & Mallorca & & & & & & (o) & \\
\hline Lachlanella undulata (d'Orbigny) & $\begin{array}{c}\text { Alboran } \\
\text { Oran } \\
\text { Mallorca }\end{array}$ & $\begin{array}{l}0 \\
0 \\
0\end{array}$ & & $\begin{array}{c}38-161 \\
48-121 \\
48-74\end{array}$ & & 0 & & \\
\hline Lachlanella sp. 1 & Alboran & 0 & & 38 & & & & \\
\hline Laevidentalina sp. 1 & Alboran & & & & (o) & & & \\
\hline Lagena doveyensis Haynes & Mallorca & o & & 94 & o & & & \\
\hline Lagena hispida Reuss var. crispata Matthes & Alboran & & & & & & (o) & \\
\hline Lagena striata (d'Orbigny) & Mallorca & 0 & & 67 & & & & \\
\hline Lagena strumosa Reuss & $\begin{array}{c}\text { Alboran } \\
\text { Oran } \\
\text { Mallorca }\end{array}$ & $\begin{array}{l}0 \\
0 \\
0\end{array}$ & & $\begin{array}{l}60-115 \\
48-127 \\
67-116\end{array}$ & $\begin{array}{l}0 \\
0\end{array}$ & & & \\
\hline Lagenammina difflugiformis (Brady) & $\begin{array}{c}\text { Oran } \\
\text { Mallorca }\end{array}$ & $\begin{array}{l}0 \\
0\end{array}$ & 67 & $\begin{array}{l}70-130 \\
74-163\end{array}$ & & & & \\
\hline Lagnea sp. 1 & Oran & o & 90 & & & & & \\
\hline Lamarckina scabra (Brady) & $\begin{array}{c}\text { Alboran } \\
\text { Oran } \\
\text { Mallorca }\end{array}$ & & & & (o) & $\begin{array}{l}\text { (0) } \\
\text { (o) } \\
\text { (o) }\end{array}$ & & \\
\hline Lenticulina calcar (Linné) & Alboran & 0 & & 161 & & & & \\
\hline Lenticulina orbicularis (d'Orbigny) & $\begin{array}{c}\text { Alboran } \\
\text { Oran } \\
\text { Mallorca }\end{array}$ & $\begin{array}{c}00 \\
0 \\
0\end{array}$ & $83-91$ & $\begin{array}{l}53-161 \\
48-130 \\
74-116\end{array}$ & & & & \\
\hline
\end{tabular}


TABLE 2 (continued).

\begin{tabular}{|c|c|c|c|c|c|c|c|c|}
\hline Lobatula lobatula (Walker and Jacob) & $\begin{array}{c}\text { Alboran } \\
\text { Oran } \\
\text { Mallorca }\end{array}$ & $\begin{array}{l}00 \\
00 \\
00\end{array}$ & $\begin{array}{c}48 ; 130 \\
40\end{array}$ & $\begin{array}{l}38-161 \\
20-130 \\
40-235\end{array}$ & $\begin{array}{c}00 \\
000\end{array}$ & $\begin{array}{c}00 \\
000\end{array}$ & 0000 & 00000 \\
\hline Marginulina costata (Batsch) & Mallorca & 0 & & 94 & & & & \\
\hline Melonis affinis (Reuss) & $\begin{array}{c}\text { Oran } \\
\text { Mallorca }\end{array}$ & $\begin{array}{l}00 \\
00\end{array}$ & $67-116$ & $\begin{array}{l}48-127 \\
40-163\end{array}$ & 0 & & & \\
\hline Melonis barleeanum (Williamson) & $\begin{array}{c}\text { Alboran } \\
\text { Oran } \\
\text { Mallorca }\end{array}$ & $\begin{array}{l}00 \\
00 \\
00\end{array}$ & $94 ; 163$ & $\begin{array}{c}53-73 \\
67-100 \\
94-235\end{array}$ & 0 & & & \\
\hline Miliolid sp. 1 & Mallorca & & & & 0 & & & \\
\hline Miliolid sp. 2 & Mallorca & & & & 0 & & 0 & \\
\hline Miliolinella elongata Kruit & $\begin{array}{c}\text { Alboran } \\
\text { Oran } \\
\text { Mallorca }\end{array}$ & $\begin{array}{c}00 \\
0 \\
00\end{array}$ & & $\begin{array}{c}63-91 \\
67-100 \\
40-80\end{array}$ & $\begin{array}{l}0 \\
0\end{array}$ & 0 & 0 & \\
\hline Miliolinella cf. hybrida (Terquem) & Mallorca & & & & 0 & 0 & 0 & \\
\hline Miliolinella irregularis (d’Orbigny) & $\begin{array}{c}\text { Alboran } \\
\text { Oran } \\
\text { Mallorca }\end{array}$ & $\begin{array}{c}00 \\
00 \\
0\end{array}$ & $61-74$ & $\begin{array}{c}38-161 \\
67-130 \\
40-94\end{array}$ & 0 & ০o & $\begin{array}{l}0 \\
\text { oo }\end{array}$ & \\
\hline Miliolinella labiosa (d’Orbigny) & $\begin{array}{c}\text { Alboran } \\
\text { Oran } \\
\text { Mallorca }\end{array}$ & $\begin{array}{l}0 \\
0\end{array}$ & & $\begin{array}{l}38 \\
94\end{array}$ & $\begin{array}{l}\text { (o) } \\
0\end{array}$ & o & 0 & 0 \\
\hline Miliolinella semicostata (Wiesner) & $\begin{array}{c}\text { Alboran } \\
\text { Oran } \\
\text { Mallorca }\end{array}$ & $\begin{array}{l}00 \\
00 \\
00\end{array}$ & $\begin{array}{c}85 \\
47-94\end{array}$ & $\begin{array}{l}38-161 \\
48-127 \\
40-235\end{array}$ & $\begin{array}{c}00 \\
0 \\
0\end{array}$ & $\begin{array}{l}0 \\
0\end{array}$ & o & o \\
\hline Miliolinella subrotunda (Montagu) & $\begin{array}{c}\text { Alboran } \\
\text { Oran } \\
\text { Mallorca }\end{array}$ & $\begin{array}{c}00 \\
0 \\
00\end{array}$ & 61 & $\begin{array}{l}38-161 \\
48-130 \\
40-235\end{array}$ & $\begin{array}{c}0 \\
00 \\
00\end{array}$ & $\begin{array}{c}00 \\
00 \\
0\end{array}$ & $\begin{array}{c}00 \\
0\end{array}$ & 00 \\
\hline Miliolinella webbiana (d’Orbigny) & $\begin{array}{c}\text { Alboran } \\
\text { Oran } \\
\text { Mallorca }\end{array}$ & $\begin{array}{c}00 \\
0 \\
0\end{array}$ & $\begin{array}{l}48 \\
67\end{array}$ & $\begin{array}{c}38-115 \\
48-85 \\
67-74\end{array}$ & $\begin{array}{l}0 \\
0\end{array}$ & $\begin{array}{l}0 \\
0\end{array}$ & 0 & o \\
\hline Miliolinella sp. 1 & $\begin{array}{c}\text { Alboran } \\
\text { Oran } \\
\text { Mallorca }\end{array}$ & $\begin{array}{l}0 \\
0 \\
0\end{array}$ & & $\begin{array}{l}53-102 \\
70-115 \\
40-163\end{array}$ & $\begin{array}{l}0 \\
0\end{array}$ & & & \\
\hline Miniacina miniacea (Pallas) & Alboran & o & & & o & 0 & & \\
\hline Mississippina sp. 1 & Alboran & 0 & & 63 & & & & \\
\hline Neoconorbina terquemi (Rzehak) & $\begin{array}{c}\text { Alboran } \\
\text { Oran } \\
\text { Mallorca }\end{array}$ & $\begin{array}{c}00 \\
000 \\
0000\end{array}$ & $\begin{array}{c}20 \\
40-80\end{array}$ & $\begin{array}{l}53-105 \\
48-130 \\
40-235\end{array}$ & $\begin{array}{c}00 \\
000 \\
0000\end{array}$ & $\begin{array}{c}0 \\
000 \\
000\end{array}$ & $\begin{array}{c}0 \\
000\end{array}$ & \\
\hline Neolenticulina peregrina (Cushman) & $\begin{array}{c}\text { Oran } \\
\text { Mallorca }\end{array}$ & & & & $\begin{array}{l}\text { (o) } \\
\text { (o) }\end{array}$ & & & \\
\hline Neouvigerina ampullacea (Brady) & $\begin{array}{l}\text { Alboran } \\
\text { Mallorca }\end{array}$ & $\begin{array}{l}\text { (o) } \\
\text { (o) }\end{array}$ & & $\begin{array}{l}161 \\
235\end{array}$ & (o) & & & \\
\hline Nonion fabum (Fichtel and Moll) & $\begin{array}{c}\text { Alboran } \\
\text { Oran } \\
\text { Mallorca }\end{array}$ & $\begin{array}{l}0 \\
0 \\
0\end{array}$ & $\begin{array}{c}83 \\
20 ; 100\end{array}$ & $\begin{array}{c}84 \\
67 ; 105-127\end{array}$ & & & 0 & \\
\hline Nonionella turgida (Williamson) & $\begin{array}{c}\text { Oran } \\
\text { Mallorca }\end{array}$ & $\begin{array}{l}0 \\
0\end{array}$ & $\begin{array}{l}118 \\
94\end{array}$ & $\begin{array}{l}67-100 \\
48-163\end{array}$ & o & o & 0 & \\
\hline Nubecularia lucifuga Defrance & $\begin{array}{l}\text { Alboran } \\
\text { Mallorca }\end{array}$ & 0 & & $38-63$ & 0 & 0 & 0 & \\
\hline
\end{tabular}




\section{MILKER \& SCHMIEDL: TAXONOMY FORAMINIFERA}

TABLE 2 (continued).

\begin{tabular}{|c|c|c|c|c|c|c|c|c|}
\hline Nubeculina divaricata (Brady) & Mallorca & & & & o & 0 & 0 & \\
\hline Nummoloculina sp. 1 & $\begin{array}{c}\text { Alboran } \\
\text { Oran } \\
\text { Mallorca }\end{array}$ & $\begin{array}{l}0 \\
0 \\
0\end{array}$ & & $\begin{array}{c}63 \\
127 \\
74-94\end{array}$ & & & & \\
\hline Oolina acuticosta (Reuss) & $\begin{array}{c}\text { Alboran } \\
\text { Oran } \\
\text { Mallorca }\end{array}$ & $\begin{array}{l}0 \\
0 \\
0\end{array}$ & & $\begin{array}{c}91-115 \\
100-127 \\
94\end{array}$ & & & & \\
\hline $\begin{array}{l}\text { Parafissurina lateralis (Cushman) carinata } \\
\text { (Buchner) }\end{array}$ & $\begin{array}{c}\text { Alboran } \\
\text { Oran } \\
\text { Mallorca }\end{array}$ & $\begin{array}{l}0 \\
0 \\
0\end{array}$ & & $\begin{array}{c}60-91 \\
100-121 \\
163\end{array}$ & o & o & & \\
\hline Parasorites marginalis (Lamarck) & Oran & 0 & 20 & 20 & & & & \\
\hline Parrellina verriculata (Brady) & $\begin{array}{c}\text { Oran } \\
\text { Mallorca }\end{array}$ & $\begin{array}{l}0 \\
0\end{array}$ & & $\begin{array}{c}70 \\
61-163\end{array}$ & 0 & 0 & & \\
\hline Patellina corrugata Williamson & $\begin{array}{c}\text { Alboran } \\
\text { Oran } \\
\text { Mallorca }\end{array}$ & $\begin{array}{c}0 \\
0 \\
00\end{array}$ & 130 & $\begin{array}{l}60-115 \\
70-118 \\
40-116\end{array}$ & $\begin{array}{l}0 \\
0 \\
0\end{array}$ & $\begin{array}{l}0 \\
0 \\
0\end{array}$ & $\begin{array}{l}0 \\
0\end{array}$ & \\
\hline Peneroplis pertusus (Forskal) & Oran & O० & 20 & 20 & & & & \\
\hline Planodiscorbis rarescens (Brady) & $\begin{array}{c}\text { Alboran } \\
\text { Oran } \\
\text { Mallorca }\end{array}$ & $\begin{array}{l}0 \\
0 \\
0\end{array}$ & $105-116$ & $\begin{array}{c}69 \\
48-127 \\
94-116\end{array}$ & $\begin{array}{l}0 \\
0\end{array}$ & & & \\
\hline Planoglabratella opercularis (d'Orbigny) & $\begin{array}{c}\text { Alboran } \\
\text { Oran } \\
\text { Mallorca }\end{array}$ & $\begin{array}{c}000 \\
0 \\
00\end{array}$ & & $\begin{array}{l}38-161 \\
20-127 \\
47-163\end{array}$ & $\begin{array}{l}0 \\
0\end{array}$ & $\begin{array}{c}0 \\
\text { oo }\end{array}$ & oo & 00 \\
\hline Planorbulina mediterranensis d'Orbigny & $\begin{array}{c}\text { Alboran } \\
\text { Oran } \\
\text { Mallorca }\end{array}$ & $\begin{array}{l}00 \\
\text { oo } \\
\text { oo }\end{array}$ & $\begin{array}{c}100 \\
74-80\end{array}$ & $\begin{array}{l}63-115 \\
20-127 \\
40-163\end{array}$ & $\begin{array}{l}0 \\
\text { oo } \\
\text { oo }\end{array}$ & $\begin{array}{l}0 \\
00 \\
00\end{array}$ & $\begin{array}{l}0 \\
\text { oo }\end{array}$ & \\
\hline Planulina ariminensis d'Orbigny & Alboran & & & & & (o) & & \\
\hline Polystomammina nitida (Brady) & Alboran & o & & 69 & & & & \\
\hline Psammosphaera fusca Schulze & Mallorca & (o) & & $94-235$ & & & & \\
\hline Pseudoclavulina crustata Cushman & $\begin{array}{c}\text { Oran } \\
\text { Mallorca }\end{array}$ & $\begin{array}{l}0 \\
0\end{array}$ & & $\begin{array}{c}84 \\
105-116\end{array}$ & & & & \\
\hline Pseudoschlumbergerina ovata (Sidebottom) & $\begin{array}{l}\text { Alboran } \\
\text { Mallorca }\end{array}$ & & & & & (o) & 0 & \\
\hline Pseudotriloculina sp. 1 & $\begin{array}{l}\text { Alboran } \\
\text { Mallorca }\end{array}$ & & & & o & & $\begin{array}{l}0 \\
0\end{array}$ & \\
\hline Ptychomiliola separans? (Brady) & $\begin{array}{c}\text { Oran } \\
\text { Mallorca }\end{array}$ & & & & (o) & (o) & 0 & \\
\hline Pullenia quadriloba Reuss & Mallorca & 0 & 105 & $94-163$ & & & & \\
\hline Pyramidulina catesbyi (d'Orbigny) & Oran & & & & & (o) & & \\
\hline Pyrgo anomala (Schlumberger) & $\begin{array}{c}\text { Alboran } \\
\text { Oran } \\
\text { Mallorca }\end{array}$ & $\begin{array}{c}0 \\
00 \\
0\end{array}$ & 115 & $\begin{array}{c}83-161 \\
100-130 \\
116\end{array}$ & & & & \\
\hline Pyrgo depressa (d'Orbigny) & $\begin{array}{c}\text { Oran } \\
\text { Mallorca }\end{array}$ & $\begin{array}{l}0 \\
0\end{array}$ & 105 & 78 & & & & \\
\hline Pyrgo elongata (d'Orbigny) & Alboran & 0 & & 115-161 & & & & \\
\hline Pyrgo oblonga (d'Orbigny) & $\begin{array}{c}\text { Alboran } \\
\text { Oran }\end{array}$ & $\begin{array}{l}0 \\
0\end{array}$ & & $\begin{array}{l}63-102 \\
85-115\end{array}$ & & & & \\
\hline
\end{tabular}


TABLE 2 (continued).

\begin{tabular}{|c|c|c|c|c|c|c|c|c|}
\hline Pyrgo sp. 1 & $\begin{array}{l}\text { Alboran } \\
\text { Oran }\end{array}$ & $\begin{array}{l}0 \\
0\end{array}$ & & $\begin{array}{c}102 \\
70-130\end{array}$ & & & & \\
\hline Pyrgo sp. 2 & Alboran & 0 & & 102 & & & & \\
\hline Pyrgoella sphaera (d’Orbigny) & Alboran & $\mathrm{o}$ & & 161 & & & & \\
\hline Quinqueloculina agglutinata Cushman & Alboran & & & & & & 0 & 0 \\
\hline Quinqueloculina auberiana d'Orbigny & Alboran & o० & & $63-69$ & & & 0 & 0 \\
\hline Quinqueloculina berthelotiana d'Orbigny & $\begin{array}{l}\text { Alboran } \\
\text { Oran } \\
\text { Mallorca }\end{array}$ & $\begin{array}{l}0 \\
0 \\
0\end{array}$ & $67 ; 74$ & 38 & & o & o० & oo \\
\hline Quinqueloculina boscianad'Orbigny & $\begin{array}{c}\text { Alboran } \\
\text { Oran } \\
\text { Mallorca }\end{array}$ & $\begin{array}{c}0 \\
0 \\
00\end{array}$ & $\begin{array}{l}20 \\
74\end{array}$ & $\begin{array}{l}60-115 \\
84-130 \\
47-235\end{array}$ & & 0 & 0 & \\
\hline Quinqueloculina disparilis d'Orbigny & $\begin{array}{c}\text { Alboran } \\
\text { Oran }\end{array}$ & $\begin{array}{l}0 \\
0\end{array}$ & & $\begin{array}{l}38 \\
48\end{array}$ & & 0 & & \\
\hline Quinqueloculina laevigata d'Orbigny & $\begin{array}{c}\text { Alboran } \\
\text { Oran } \\
\text { Mallorca }\end{array}$ & $\begin{array}{l}\text { ०o } \\
\text { oo } \\
\text { oo }\end{array}$ & $74 ; 163$ & $\begin{array}{c}38-86 \\
48-127 \\
48-163\end{array}$ & $\begin{array}{l}0 \\
0\end{array}$ & $\begin{array}{l}0 \\
0\end{array}$ & ○ & o \\
\hline Quinqueloculina lata Terquem & $\begin{array}{c}\text { Alboran } \\
\text { Oran } \\
\text { Mallorca }\end{array}$ & $\begin{array}{l}0 \\
0 \\
0\end{array}$ & 67 & $\begin{array}{c}48 \\
61-94\end{array}$ & 0 & 0 & 0 & 0 \\
\hline Quinqueloculina limbata d'Orbigny & $\begin{array}{c}\text { Alboran } \\
\text { Oran } \\
\text { Mallorca }\end{array}$ & $\begin{array}{c}0 \\
\text { oo } \\
\text { o० }\end{array}$ & $\begin{array}{c}20 \\
47-67\end{array}$ & $\begin{array}{c}38 \\
20 \\
40-47\end{array}$ & & & & \\
\hline $\begin{array}{l}\text { Quinqueloculina neapolitana Sgarrella and } \\
\text { Moncharmont Zei }\end{array}$ & Alboran & & & & & & (o) & \\
\hline Quinqueloculina padana Perconig & $\begin{array}{c}\text { Alboran } \\
\text { Oran } \\
\text { Mallorca }\end{array}$ & $\begin{array}{l}0 \\
0 \\
0\end{array}$ & 105 & $\begin{array}{c}60-97 \\
73-127 \\
67 ; 105-235\end{array}$ & 0 & & & \\
\hline Quinqueloculina parvula Schlumberger & $\begin{array}{c}\text { Alboran } \\
\text { Oran } \\
\text { Mallorca }\end{array}$ & $\begin{array}{c}00 \\
0 \\
00\end{array}$ & & $\begin{array}{c}38-60 ; 86 \\
70-127 \\
48-94\end{array}$ & $\begin{array}{c}\circ \\
\text { oo }\end{array}$ & $\begin{array}{c}0 \\
0 \\
00\end{array}$ & oo & \\
\hline Quinqueloculina pseudobuchiana Luczkowksa & $\begin{array}{l}\text { Alboran } \\
\text { Mallorca }\end{array}$ & $\begin{array}{l}0 \\
0\end{array}$ & & $\begin{array}{c}63 \\
105\end{array}$ & & & & \\
\hline Quinqueloculina seminula (Linné) & $\begin{array}{c}\text { Alboran } \\
\text { Oran } \\
\text { Mallorca }\end{array}$ & $\begin{array}{c}00 \\
0000 \\
00\end{array}$ & & $\begin{array}{l}38-161 \\
20-130 \\
40-163\end{array}$ & $\begin{array}{l}0 \\
0 \\
0\end{array}$ & $\begin{array}{l}0 \\
0\end{array}$ & oo & oo \\
\hline Quinqueloculina stelligera Schlumberger & $\begin{array}{c}\text { Alboran } \\
\text { Oran } \\
\text { Mallorca }\end{array}$ & $\begin{array}{l}\text { ०० } \\
\text { ०० } \\
\text { ०० }\end{array}$ & 48 & $\begin{array}{c}38-91 \\
48-127 \\
40-61 ; 94\end{array}$ & $\begin{array}{l}0 \\
\text { oo } \\
\text { oo }\end{array}$ & $\begin{array}{l}0 \\
\text { oo } \\
\text { oo }\end{array}$ & $\begin{array}{l}0 \\
\text { oo }\end{array}$ & \\
\hline $\begin{array}{l}\text { Quinqueloculina viennensis Le Calvez and Le } \\
\text { Calvez }\end{array}$ & $\begin{array}{c}\text { Alboran } \\
\text { Oran } \\
\text { Mallorca }\end{array}$ & $\begin{array}{c}00 \\
0 \\
00\end{array}$ & & $\begin{array}{c}38-97 \\
70-127 \\
40-116\end{array}$ & $\begin{array}{l}0 \\
0 \\
0\end{array}$ & $\begin{array}{l}0 \\
0\end{array}$ & o & o \\
\hline Quinqueloculina sp. 1 & Mallorca & & & & & o & 0 & \\
\hline Rectuvigerina bononiensis (Fornasini) & $\begin{array}{c}\text { Alboran } \\
\text { Oran }\end{array}$ & $\begin{array}{c}0 \\
\text { oo }\end{array}$ & 84 & $\begin{array}{c}69 \\
84-121\end{array}$ & 0 & & & \\
\hline Rectuvigerina phlegeri Le Calvez & $\begin{array}{c}\text { Alboran } \\
\text { Oran } \\
\text { Mallorca }\end{array}$ & $\begin{array}{l}0 \\
0 \\
0\end{array}$ & $48-121$ & $\begin{array}{c}73 \\
48-130 \\
116\end{array}$ & 0 & 0 & o & \\
\hline
\end{tabular}


MILKER \& SCHMIEDL: TAXONOMY FORAMINIFERA

TABLE 2 (continued).

\begin{tabular}{|c|c|c|c|c|c|c|c|c|}
\hline Reophax scorpiurus Montfort & $\begin{array}{c}\text { Oran } \\
\text { Mallorca }\end{array}$ & $\begin{array}{l}0 \\
0\end{array}$ & $67-130$ & $\begin{array}{c}67-121 \\
74-94\end{array}$ & & & & \\
\hline Repmanina charoides (Jones and Parker) & Alboran & & & & (o) & & & \\
\hline Reussella spinulosa (Reuss) & $\begin{array}{c}\text { Oran } \\
\text { Mallorca }\end{array}$ & $\begin{array}{l}00 \\
00\end{array}$ & 74 & $\begin{array}{l}67-100 \\
48-163\end{array}$ & $\begin{array}{l}00 \\
00\end{array}$ & $\begin{array}{c}0 \\
00\end{array}$ & 0 & \\
\hline Rhabdamminella cylindrica (Brady) & Alboran & 0 & & 97 & & & & \\
\hline Robertina translucens Cushman and Parker & $\begin{array}{l}\text { Alboran } \\
\text { Mallorca }\end{array}$ & $\begin{array}{l}0 \\
0\end{array}$ & & $\begin{array}{c}60 \\
61-163\end{array}$ & 0 & o & & \\
\hline Rosalina anomala Terquem & $\begin{array}{c}\text { Alboran } \\
\text { Oran } \\
\text { Mallorca }\end{array}$ & $\begin{array}{l}00 \\
00 \\
00\end{array}$ & & $\begin{array}{c}38-161 \\
67-130 \\
40-80\end{array}$ & o & $\begin{array}{l}0 \\
0 \\
0\end{array}$ & 0 & \\
\hline Rosalina bradyi Cushman & $\begin{array}{c}\text { Alboran } \\
\text { Oran } \\
\text { Mallorca }\end{array}$ & $\begin{array}{c}00 \\
0 \\
00\end{array}$ & $\begin{array}{c}73 \\
40 ; 74\end{array}$ & $\begin{array}{c}38-86 ; 86-161 \\
48-130 \\
40-80 ; 80-235\end{array}$ & $\begin{array}{l}0 \\
00 \\
00\end{array}$ & $\begin{array}{l}00 \\
\text { oo } \\
\text { oo }\end{array}$ & $\begin{array}{l}00 \\
00\end{array}$ & \\
\hline Rosalina globularis d'Orbigny & $\begin{array}{c}\text { Alboran } \\
\text { Oran } \\
\text { Mallorca }\end{array}$ & $\begin{array}{l}0 \\
0 \\
0\end{array}$ & & $\begin{array}{c}38 \\
67 \\
40-48 ; 94-235\end{array}$ & $\begin{array}{l}0 \\
0\end{array}$ & o & 0 & \\
\hline Rosalina macropora (Hofker) & $\begin{array}{c}\text { Alboran } \\
\text { Oran } \\
\text { Mallorca }\end{array}$ & $\begin{array}{l}0 \\
00 \\
00\end{array}$ & $\begin{array}{c}73 ; 100 \\
48 ; 67\end{array}$ & $\begin{array}{c}38-83 ; 115 \\
20-121 \\
40-235\end{array}$ & $\begin{array}{c}\text { ০o } \\
0\end{array}$ & $\begin{array}{c}0 \\
00 \\
0\end{array}$ & $\begin{array}{l}0 \\
\text { oo }\end{array}$ & \\
\hline Rosalina sp. 1 & $\begin{array}{c}\text { Alboran } \\
\text { Oran } \\
\text { Mallorca }\end{array}$ & $\begin{array}{l}00 \\
00 \\
00\end{array}$ & & $\begin{array}{c}60-115 \\
70-121 \\
47-56 ; 163\end{array}$ & $\begin{array}{c}00 \\
0\end{array}$ & $\begin{array}{l}0 \\
0\end{array}$ & 00 & o० \\
\hline Sahulia cf. kerimbaensis (Said) & $\begin{array}{c}\text { Alboran } \\
\text { Oran } \\
\text { Mallorca }\end{array}$ & $\begin{array}{c}00 \\
00 \\
0\end{array}$ & & $\begin{array}{l}63-161 \\
70-130 \\
40-116\end{array}$ & 0 & $\mathrm{o}$ & & \\
\hline Schackionella imperiatoria (d'Orbigny) & $\begin{array}{l}\text { Alboran } \\
\text { Mallorca }\end{array}$ & o & & $67-235$ & 0 & o & & \\
\hline Sejunctella cf. lateseptata (Terquem) & Oran & & & & (o) & (o) & & \\
\hline Sigmavirgulina tortuosa (Brady) & $\begin{array}{l}\text { Alboran } \\
\text { Mallorca }\end{array}$ & & & & & (o) & $\begin{array}{l}\text { (o) } \\
\text { (o) }\end{array}$ & \\
\hline Sigmavirgulina sp. 1 & $\begin{array}{c}\text { Alboran } \\
\text { Oran } \\
\text { Mallorca }\end{array}$ & $\begin{array}{l}0 \\
0\end{array}$ & & $\begin{array}{c}73 \\
61-163\end{array}$ & o & o & 0 & \\
\hline Sigmoilinita costata (Schlumberger) & $\begin{array}{c}\text { Alboran } \\
\text { Oran } \\
\text { Mallorca }\end{array}$ & $\begin{array}{l}00 \\
00 \\
00\end{array}$ & & $\begin{array}{c}38-91 \\
48-130 \\
40-235\end{array}$ & $\begin{array}{c}0 \\
\text { oo } \\
0\end{array}$ & $\begin{array}{c}\text { oo } \\
\text { o }\end{array}$ & oo & \\
\hline Sigmoilinita distorta (Phleger and Parker) & $\begin{array}{c}\text { Alboran } \\
\text { Oran } \\
\text { Mallorca }\end{array}$ & $\begin{array}{c}0 \\
00 \\
0\end{array}$ & & $\begin{array}{l}73-115 \\
48-100 \\
94-235\end{array}$ & & o & o & \\
\hline Sigmoilinita sp. 1 & Oran & & & & (o) & (o) & & \\
\hline Sigmoilopsis schlumbergeri (Silvestri) & $\begin{array}{c}\text { Alboran } \\
\text { Oran } \\
\text { Mallorca }\end{array}$ & $\begin{array}{l}0 \\
00 \\
00\end{array}$ & & $\begin{array}{l}63-115 \\
70-130 \\
94-235\end{array}$ & & & & \\
\hline Sigmoilopsis sp. 1 & $\begin{array}{c}\text { Alboran } \\
\text { Oran } \\
\text { Mallorca }\end{array}$ & $\begin{array}{c}0 \\
0 \\
00\end{array}$ & & $\begin{array}{c}64-69 \\
48-127 \\
105\end{array}$ & o & & & \\
\hline Siphonaperta agglutinans (d'Orbigny) & Mallorca & & & & & & (o) & \\
\hline
\end{tabular}


TABLE 2 (continued).

\begin{tabular}{|c|c|c|c|c|c|c|c|c|}
\hline Siphonaperta aspera (d'Orbigny) & $\begin{array}{c}\text { Alboran } \\
\text { Oran } \\
\text { Mallorca }\end{array}$ & $\begin{array}{l}0 \\
0 \\
0\end{array}$ & & $\begin{array}{c}60 \\
48-83 \\
40-116\end{array}$ & & & & \\
\hline $\begin{array}{l}\text { Siphonaperta dilatata (Le Calvez and Le } \\
\text { Calvez) }\end{array}$ & $\begin{array}{l}\text { Alboran } \\
\text { Mallorca }\end{array}$ & 0 & & 38 & $\begin{array}{c}0 \\
00\end{array}$ & $\begin{array}{c}0 \\
\text { oo }\end{array}$ & $\begin{array}{c}0 \\
\text { oo }\end{array}$ & \\
\hline Siphonaperta horrida (Cushman) & $\begin{array}{c}\text { Oran } \\
\text { Mallorca }\end{array}$ & $\begin{array}{l}00 \\
\infty\end{array}$ & & $\begin{array}{l}20-118 \\
80-105\end{array}$ & o & & & \\
\hline Siphonaperta irregularis (d'Orbigny) & $\begin{array}{c}\text { Alboran } \\
\text { Oran } \\
\text { Mallorca }\end{array}$ & $\begin{array}{c}0 \\
0 \\
00\end{array}$ & 48 & $\begin{array}{c}38-53 \\
48-118 \\
40-235 ; 40-47\end{array}$ & & 0 & 0 & \\
\hline Siphonaperta sp. 1 & $\begin{array}{c}\text { Alboran } \\
\text { Oran } \\
\text { Mallorca }\end{array}$ & $\begin{array}{l} \\
0 \\
0\end{array}$ & & $\begin{array}{c}38-97 \\
48 \\
48-94\end{array}$ & 0 & 0 & 0 & \\
\hline Siphonaperta sp. 2 & $\begin{array}{c}\text { Alboran } \\
\text { Oran } \\
\text { Mallorca }\end{array}$ & $\begin{array}{l}\text { ০o } \\
\text { ০o }\end{array}$ & & $\begin{array}{c}48-76 ; 118-130 \\
40-94\end{array}$ & $\begin{array}{c}0 \\
0 \\
00\end{array}$ & $\begin{array}{l}0 \\
0 \\
0\end{array}$ & 0 & \\
\hline Siphonina reticulata (Czjzek) & $\begin{array}{c}\text { Alboran } \\
\text { Oran } \\
\text { Mallorca }\end{array}$ & $\begin{array}{l}0 \\
0 \\
0\end{array}$ & 127 & $\begin{array}{c}102 \\
48-84 \\
94-235\end{array}$ & & & & \\
\hline Siphoninella soluta (Brady) & Mallorca & & & & (o) & (o) & (o) & \\
\hline Siphotextularia concava (Karrer) & $\begin{array}{c}\text { Alboran } \\
\text { Oran } \\
\text { Mallorca }\end{array}$ & $\begin{array}{l}00 \\
\text { oo } \\
\text { oo }\end{array}$ & 86 & $\begin{array}{l}64-115 \\
48-130 \\
48-163\end{array}$ & $\begin{array}{l}0 \\
0 \\
0\end{array}$ & 0 & 0 & \\
\hline Siphotextularia flintii (Cushman) & $\begin{array}{c}\text { Alboran } \\
\text { Oran } \\
\text { Mallorca }\end{array}$ & $\begin{array}{c}00 \\
0 \\
0\end{array}$ & & $\begin{array}{c}63-115 \\
48-100 \\
47-48\end{array}$ & & & & \\
\hline Siphouvigerina? sp. 1 & $\begin{array}{c}\text { Alboran } \\
\text { Oran } \\
\text { Mallorca }\end{array}$ & & & & & $\begin{array}{l}0 \\
0\end{array}$ & o & \\
\hline Sphaerogypsina globula (Reuss) & $\begin{array}{c}\text { Alboran } \\
\text { Oran } \\
\text { Mallorca }\end{array}$ & $\begin{array}{l}00 \\
\text { oo } \\
\text { oo }\end{array}$ & 40 & $\begin{array}{c}38-161 \\
48-121 \\
40-94\end{array}$ & $\begin{array}{l}00 \\
\text { oo }\end{array}$ & $\begin{array}{c}00 \\
\circ\end{array}$ & o & \\
\hline Sphaeroidina bulloides d'Orbigny & Mallorca & 0 & & 116-163 & & & & \\
\hline Spirillina limbata Brady & $\begin{array}{c}\text { Alboran } \\
\text { Oran } \\
\text { Mallorca }\end{array}$ & $\begin{array}{c}00 \\
0 \\
0\end{array}$ & 91 & $\begin{array}{c}38-97 \\
70-121 \\
80-94\end{array}$ & 0 & & & \\
\hline Spirillina vivipara Ehrenberg & $\begin{array}{l}\text { Alboran } \\
\text { Oran } \\
\text { Mallorca }\end{array}$ & $\begin{array}{l}\text { oo } \\
\text { oo } \\
\text { oo }\end{array}$ & $\begin{array}{c}63 \\
48 ; 100- \\
130 \\
61\end{array}$ & $\begin{array}{l}38-115 \\
48-121 \\
40-235\end{array}$ & $\begin{array}{l}00 \\
\text { o० } \\
\text { oo }\end{array}$ & $\begin{array}{l}00 \\
00 \\
\text { oo }\end{array}$ & oo & \\
\hline Spirillina wrightii Heron-Allen and Earland & $\begin{array}{c}\text { Alboran } \\
\text { Oran }\end{array}$ & $\begin{array}{l}0 \\
0\end{array}$ & & $\begin{array}{l}53-83 \\
48-85\end{array}$ & & & & \\
\hline Spirillina sp. 1 & Oran & & & & & (o) & & \\
\hline Spirillinid sp. 1 & $\begin{array}{c}\text { Alboran } \\
\text { Oran }\end{array}$ & $\begin{array}{l}0 \\
0\end{array}$ & & $\begin{array}{c}38-73 \\
48-130\end{array}$ & $\begin{array}{l}0 \\
0\end{array}$ & $\begin{array}{l}0 \\
0\end{array}$ & 0 & \\
\hline Spiroloculina dilatata d'Orbigny & $\begin{array}{c}\text { Alboran } \\
\text { Oran } \\
\text { Mallorca }\end{array}$ & $\begin{array}{c}00 \\
0 \\
0\end{array}$ & & $\begin{array}{c}38-69 \\
48-130 \\
47-163\end{array}$ & $\begin{array}{l}0 \\
0\end{array}$ & & & \\
\hline
\end{tabular}


MILKER \& SCHMIEDL: TAXONOMY FORAMINIFERA

TABLE 2 (continued).

\begin{tabular}{|c|c|c|c|c|c|c|c|c|}
\hline Spiroloculina excavata d'Orbigny & $\begin{array}{c}\text { Alboran } \\
\text { Oran } \\
\text { Mallorca }\end{array}$ & $\begin{array}{l}0 \\
0 \\
0\end{array}$ & & $\begin{array}{l}64-161 \\
70-127 \\
94-163\end{array}$ & 0 & & & \\
\hline Spiroloculina cf. rostrata Reuss & $\begin{array}{c}\text { Alboran } \\
\text { Oran } \\
\text { Mallorca }\end{array}$ & $\begin{array}{l}0 \\
0 \\
0\end{array}$ & & $\begin{array}{c}64-91 \\
48-130 \\
80\end{array}$ & $\begin{array}{l}0 \\
0\end{array}$ & & & \\
\hline Spiroloculina tenuiseptata Brady & $\begin{array}{c}\text { Alboran } \\
\text { Oran } \\
\text { Mallorca }\end{array}$ & $\begin{array}{c}0 \\
00 \\
0\end{array}$ & & $\begin{array}{c}63-91 \\
48-130 \\
67-116\end{array}$ & $\begin{array}{l}0 \\
0\end{array}$ & 0 & & \\
\hline Spiroloculina sp. 1 & $\begin{array}{c}\text { Alboran } \\
\text { Oran } \\
\text { Mallorca }\end{array}$ & $\begin{array}{c}0 \\
00 \\
0\end{array}$ & & $\begin{array}{l}53-115 \\
67-127 \\
74-105\end{array}$ & & & & \\
\hline Spiroloculina sp. 2 & $\begin{array}{c}\text { Alboran } \\
\text { Oran } \\
\text { Mallorca }\end{array}$ & $\begin{array}{l}0 \\
0 \\
0\end{array}$ & & $\begin{array}{l}60-115 \\
70-121 \\
40-163\end{array}$ & $\begin{array}{l}0 \\
\circ\end{array}$ & $\begin{array}{l}0 \\
0 \\
0\end{array}$ & $\begin{array}{l}0 \\
0\end{array}$ & \\
\hline Spiroloculina sp. 3 & $\begin{array}{c}\text { Oran } \\
\text { Mallorca }\end{array}$ & $\begin{array}{l}0 \\
0\end{array}$ & & $\begin{array}{c}90-121 \\
56\end{array}$ & & & & \\
\hline $\begin{array}{l}\text { Spirophthalmidium acutimargo (Brady) var. } \\
\text { concava(Wiesner) }\end{array}$ & Mallorca & & & & (o) & & & \\
\hline Spirophthalmidium sp. 1 & $\begin{array}{c}\text { Alboran } \\
\text { Oran } \\
\text { Mallorca }\end{array}$ & 0 & & 83 & (o) & 0 & o & \\
\hline Spirophthalmidium sp. 2 & Mallorca & & & & & & 0 & \\
\hline Spiroplectinella sagittula s.l. (Defrance) & $\begin{array}{c}\text { Alboran } \\
\text { Oran } \\
\text { Mallorca }\end{array}$ & $\begin{array}{c}00 \\
000 \\
0000\end{array}$ & 94 & $\begin{array}{c}38-161 ; 86-91 \\
48-130 ; 73-130 \\
40-235 ; 67-94\end{array}$ & $\begin{array}{c}0 \\
0 \\
00\end{array}$ & $\begin{array}{l}0 \\
0\end{array}$ & 0 & \\
\hline Spiroplectinella sp. 1 & $\begin{array}{c}\text { Alboran } \\
\text { Oran } \\
\text { Mallorca }\end{array}$ & $\begin{array}{l}\infty \\
\infty 0 \\
\infty 0\end{array}$ & & $\begin{array}{c}48-85 \\
53-115 \\
47-116\end{array}$ & $\begin{array}{c}0 \\
0 \\
\text { oo }\end{array}$ & $\begin{array}{l}0 \\
\text { oo }\end{array}$ & & \\
\hline Spiroplectinella sp. 2 & $\begin{array}{c}\text { Alboran } \\
\text { Oran } \\
\text { Mallorca }\end{array}$ & $\begin{array}{l}00 \\
\text { oo } \\
\text { oo }\end{array}$ & 127 & $\begin{array}{c}60-161 \\
48-130 ; 97-121 \\
67-163\end{array}$ & 0 & 0 & & \\
\hline Spirorbina? sp. 1 & $\begin{array}{c}\text { Alboran } \\
\text { Oran } \\
\text { Mallorca }\end{array}$ & $\begin{array}{l}0 \\
0 \\
0\end{array}$ & & $\begin{array}{c}38 \\
67 \\
40-48 ; 105-235\end{array}$ & oo & 0 & oo & \\
\hline Stainforthia complanata (Egger) & $\begin{array}{c}\text { Oran } \\
\text { Mallorca }\end{array}$ & o & 67 & & 0 & 0 & & \\
\hline Stomatorbina concentrica (Parker and Jones) & $\begin{array}{c}\text { Alboran } \\
\text { Oran } \\
\text { Mallorca }\end{array}$ & $\begin{array}{c}00 \\
00 \\
0\end{array}$ & $\begin{array}{c}61 ; 91 \\
100-130\end{array}$ & $\begin{array}{c}38-161 \\
48-127 \\
94\end{array}$ & $\begin{array}{l}0 \\
0\end{array}$ & o & & \\
\hline Svratkina sp. 1 & $\begin{array}{l}\text { Alboran } \\
\text { Mallorca }\end{array}$ & & & & & & $\begin{array}{l}0 \\
0\end{array}$ & \\
\hline Textularia agglutinans d'Orbigny & $\begin{array}{c}\text { Alboran } \\
\text { Oran } \\
\text { Mallorca }\end{array}$ & $\begin{array}{l}0 \\
\text { oo } \\
\text { oo }\end{array}$ & & $\begin{array}{l}60-115 \\
20-121 \\
47-163\end{array}$ & 0 & & & \\
\hline Textularia calva Lalicker & $\begin{array}{c}\text { Alboran } \\
\text { Oran } \\
\text { Mallorca }\end{array}$ & $\begin{array}{c}0 \\
\text { oo } \\
\text { oo }\end{array}$ & $40-163$ & $\begin{array}{c}69-73 \\
40-130 \\
47-235\end{array}$ & $\begin{array}{l}\text { oo } \\
\text { oo }\end{array}$ & $\begin{array}{c}\circ \\
\text { oo }\end{array}$ & oo & \\
\hline
\end{tabular}


TABLE 2 (continued).

\begin{tabular}{|c|c|c|c|c|c|c|c|c|}
\hline Textularia conica d'Orbigny & $\begin{array}{c}\text { Alboran } \\
\text { Oran } \\
\text { Mallorca }\end{array}$ & $\begin{array}{l}0 \\
\text { oo } \\
\text { oo }\end{array}$ & & $\begin{array}{l}83-163 \\
40-130 \\
40-235\end{array}$ & $\begin{array}{l}0 \\
0\end{array}$ & 0 & 0 & \\
\hline Textularia gramen d'Orbigny & $\begin{array}{c}\text { Alboran } \\
\text { Oran } \\
\text { Mallorca }\end{array}$ & $\begin{array}{l}0 \\
\text { oo } \\
\text { oo }\end{array}$ & $61-105$ & $\begin{array}{c}64-97 \\
48-130 \\
40-235\end{array}$ & $\begin{array}{l}0 \\
0\end{array}$ & $\begin{array}{l}0 \\
0\end{array}$ & 0 & \\
\hline Textularia pala Czjzek & $\begin{array}{c}\text { Alboran } \\
\text { Oran } \\
\text { Mallorca }\end{array}$ & $\begin{array}{l}00 \\
00 \\
\text { oo }\end{array}$ & $\begin{array}{c}78 \\
40-94\end{array}$ & $\begin{array}{l}38-115 \\
48-130 \\
40-235\end{array}$ & $\begin{array}{l}0 \\
0 \\
0\end{array}$ & $\begin{array}{c}0 \\
00 \\
0\end{array}$ & & \\
\hline Textularia pseudorugosa Lacroix & $\begin{array}{c}\text { Alboran } \\
\text { Oran } \\
\text { Mallorca }\end{array}$ & $\begin{array}{c}00 \\
000 \\
0\end{array}$ & 161 & $\begin{array}{l}53-161 \\
70-130 \\
47-116\end{array}$ & $\begin{array}{l}0 \\
0\end{array}$ & $\begin{array}{l}0 \\
0\end{array}$ & 0 & \\
\hline Tretomphalus concinnus (Brady) & $\begin{array}{c}\text { Alboran } \\
\text { Oran } \\
\text { Mallorca }\end{array}$ & $\begin{array}{c}00 \\
0 \\
00\end{array}$ & & $\begin{array}{c}38-69 \\
73-83 \\
94-235\end{array}$ & $\begin{array}{c}0 \\
0 \\
00\end{array}$ & $\begin{array}{l}00 \\
00 \\
00\end{array}$ & $\begin{array}{l}00 \\
000\end{array}$ & oo \\
\hline Tretomphalus sp. 1 & $\begin{array}{c}\text { Alboran } \\
\text { Oran } \\
\text { Mallorca }\end{array}$ & $\begin{array}{c}00 \\
0 \\
0\end{array}$ & & $\begin{array}{c}53-69 ; 115 \\
48 ; 100-118 \\
40-235\end{array}$ & $\begin{array}{c}00 \\
0 \\
000\end{array}$ & $\begin{array}{c}00 \\
0 \\
00\end{array}$ & $\begin{array}{l}00 \\
\text { oo }\end{array}$ & \\
\hline Trifarina fornasinii (Selli) & Alboran & & & & (o) & & & \\
\hline Triloculina oblonga (Montagu) & $\begin{array}{c}\text { Alboran } \\
\text { Oran }\end{array}$ & $\begin{array}{l}0 \\
0\end{array}$ & & $\begin{array}{l}60 \\
67\end{array}$ & o & o & & \\
\hline Triloculina plicata Terquem & $\begin{array}{c}\text { Alboran } \\
\text { Oran } \\
\text { Mallorca }\end{array}$ & 0 & & $48-130$ & $\begin{array}{c}0 \\
\text { (o) }\end{array}$ & $\begin{array}{l}0 \\
0\end{array}$ & 0 & (o) \\
\hline Triloculina marioni Schlumberger & $\begin{array}{c}\text { Alboran } \\
\text { Oran } \\
\text { Mallorca }\end{array}$ & $\begin{array}{l}0 \\
0\end{array}$ & 74 & $90-127$ & $\begin{array}{l}\text { (o) } \\
0 \\
0\end{array}$ & $\begin{array}{l}0) \\
0 \\
0\end{array}$ & $\begin{array}{c}\text { (o) } \\
0 \\
0\end{array}$ & \\
\hline Triloculina tricarinata d'Orbigny & $\begin{array}{c}\text { Alboran } \\
\text { Oran } \\
\text { Mallorca }\end{array}$ & $\begin{array}{c}0 \\
00 \\
0\end{array}$ & & $\begin{array}{c}102-161 \\
67-83 \\
40-163\end{array}$ & 0 & 0 & & \\
\hline Triloculina sp. 1 & $\begin{array}{c}\text { Alboran } \\
\text { Oran } \\
\text { Mallorca }\end{array}$ & $\begin{array}{c}0 \\
00 \\
0\end{array}$ & & $\begin{array}{c}83-115 \\
48-130 \\
105\end{array}$ & & & & \\
\hline Trimosina sp.1 & Mallorca & & & & & & (o) & \\
\hline Trisegmentina compressa Wiesner & Mallorca & o & & 105 & & & & \\
\hline Tritaxis fusca(Williamson) & Mallorca & 0 & & 163 & & & & \\
\hline Trocholinopsis ornata Sidebottom & $\begin{array}{c}\text { Alboran } \\
\text { Oran }\end{array}$ & & & & 0 & $\begin{array}{l}0 \\
0\end{array}$ & 0 & \\
\hline Uvigerina mediterraneaHofker & Mallorca & (o) & & $105-235$ & (o) & & & \\
\hline Uvigerina peregrina Cushman & $\begin{array}{c}\text { Alboran } \\
\text { Oran } \\
\text { Mallorca }\end{array}$ & $\begin{array}{l}\text { oo } \\
\text { oo } \\
\text { oo }\end{array}$ & $\begin{array}{l}48-127 \\
94-235\end{array}$ & $\begin{array}{l}102-115 \\
67-130 \\
94-235\end{array}$ & & & & \\
\hline Uvigerina sp. 1 & Mallorca & & & & & & 0 & \\
\hline Vaginulina cf. americana Cushman & $\begin{array}{c}\text { Alboran } \\
\text { Oran }\end{array}$ & $\begin{array}{l}0 \\
0\end{array}$ & & $\begin{array}{c}86-161 \\
130\end{array}$ & & & & \\
\hline Valvulineria complanata (Fornasini) & $\begin{array}{c}\text { Alboran } \\
\text { Oran } \\
\text { Mallorca }\end{array}$ & $\begin{array}{c}0 \\
\text { oo } \\
0\end{array}$ & $\begin{array}{c}100 \\
67-105\end{array}$ & $\begin{array}{l}53-102 \\
48-130 \\
80-163\end{array}$ & 0 & 0 & & \\
\hline
\end{tabular}


TABLE 2 (continued).

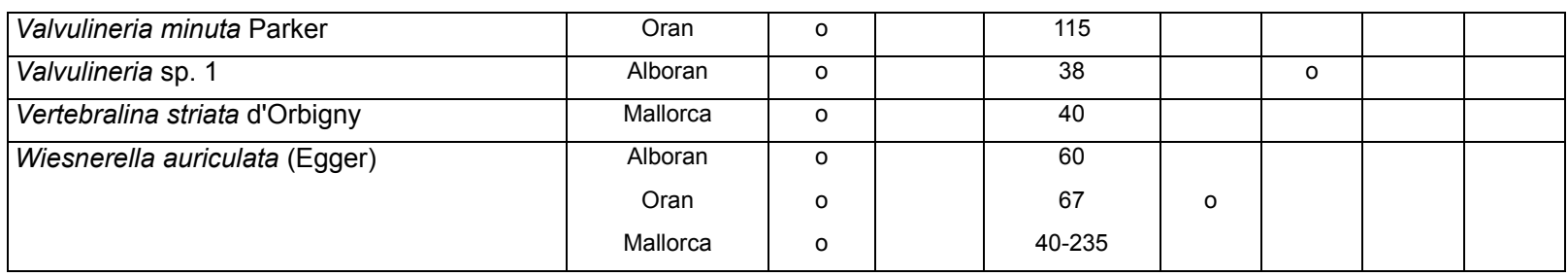

taxa) (Figure 6, Table 3). A Cassidulina laevigata s.l.-assemblage, containing Bulimina elongata as further dominant taxon, and a Gavelinopsis praegeri-assemblage with $G$. subglobosa and $C$. obtusa as associated taxa were restricted to the deeper sites (Figure 6, Table 3).

A Redundancy Analysis (RDA), applied on the dead foraminiferal assemblages to find out species-environment relations, has shown that the water depth appeared as an important parameter. It is significantly positive correlated with RDA axis 1 (Table 4). C. obtusa, G. subglobosa and probably $G$. praegeri are correlated to deeper water depths, whereas $N$. terquemi and $A$. mamilla s.l. are clearly related to shallower water depths (Figure 7). On the other hand, C. leavigata s.l., B. elongata, $D$. bertheloti and. G. oblonga show a close relation to a higher content of fine-grained material.

As shown by the PCA and RDA results, the dead faunas of the shallow circalittoral were dominated by epifaunal species. On the Mallorca Shelf, the lower limit of the distribution of the shallowwater assemblages is associated with a change in grain size composition of the substrate from coarse-grained carbonate material to finer-grained carbonate material at around $96 \mathrm{~m}$ water depth. Although, no bathymetric shift in substrate is present on the Alboran Platform and in the Oran Bight, a faunal shift has also been observed at around 80 $\mathrm{m}$ water depth in both areas. At the deeper sites, the most characteristic taxa belonged to the Cassidulinidae, with $C$. obtusa, G. subglobosa, C. laevigata s.l. and G. oblonga. On the Alboran Platform and in the Oran Bight, these species were often associated with typical species for highenergy shelf environments and sandy substrates such as E. complanatum, C. refulgens, L. Iobatula, C. pseudoungerianus and G. praegeri (see Milker et al., 2009, and references therein). On the Mallorca Shelf, the higher numbers of $C$. laevigata s.l. were restricted to fine-grained carbonate material.

These observations suggest that the benthic ecosystems in the study areas are not only influenced by near-bottom currents and local sea floor topography but also by winnowing and lateral transport of sediment and organic matter particles.

A PCA, applied on the fossil foraminifera in the core samples, provides insights in the temporal ecosystem evolution from the latest glacial period to the Holocene in the study areas. On the Alboran Platform, a Lobatula lobatula-assemblage with Elphidium sp. 1, Elphidium complanatum forma tyrrhenianum and Elphidium aculeatum as further taxa dominated during the latest glacial period and early Holocene (Figure 8, Table 5). An assemblage consisting of Asterigerinata mamilla, E. complanatum, Spirillina vivipara and Brizalina difformis as important taxa dominated during the early and middle Holocene and was then replaced by a Cibicidoides pseudoungerianus-assemblage with Globocassidulina subglobosa, Cassidulina obtusa and $L$. Iobatula as associated species in the late Holocene (Figure 8, Table 5). In the Oran Bight core, A. mamilla dominates during the complete time interval preserved in the core. This species was dominant together with L. lobatula and Rosalina macropora as well as Quinqueloculina stelligera as further important taxa throughout the core with decreasing loadings from the middle to late Holocene (Figure 8, Table 5). An assemblage consisting of $A$. mamilla in association with G. subglobosa and Discorbinella bertheloti as well as $E$. complanatum as further taxa showed increasing loadings from the middle to the late Holocene (Figure 8). On the Mallorca Shelf, the earliest Holocene was characterized by the dominance of Tretomphalus concinnus with Sigmoilinita costata, Spirorbina sp. 1 and Q. stelligera as associated taxa (Figure 8, Table 5). A Neoconorbina terquemi assemblage with Tretomphalus sp. 1 as associated taxon, occurred during the Holocene, but was replaced by a Cassidulina laevigata s.l.-assemblage with Tretomphalus sp. 1, Reussella spinulosa and Spirillina vivipara as further dominant species during the middle to late Holocene interval (Figure 8, Table 5).

It has been shown, that the dominant fossil benthic foraminiferal assemblages in all cores gen- 


\section{"Living" benthic foraminifera}
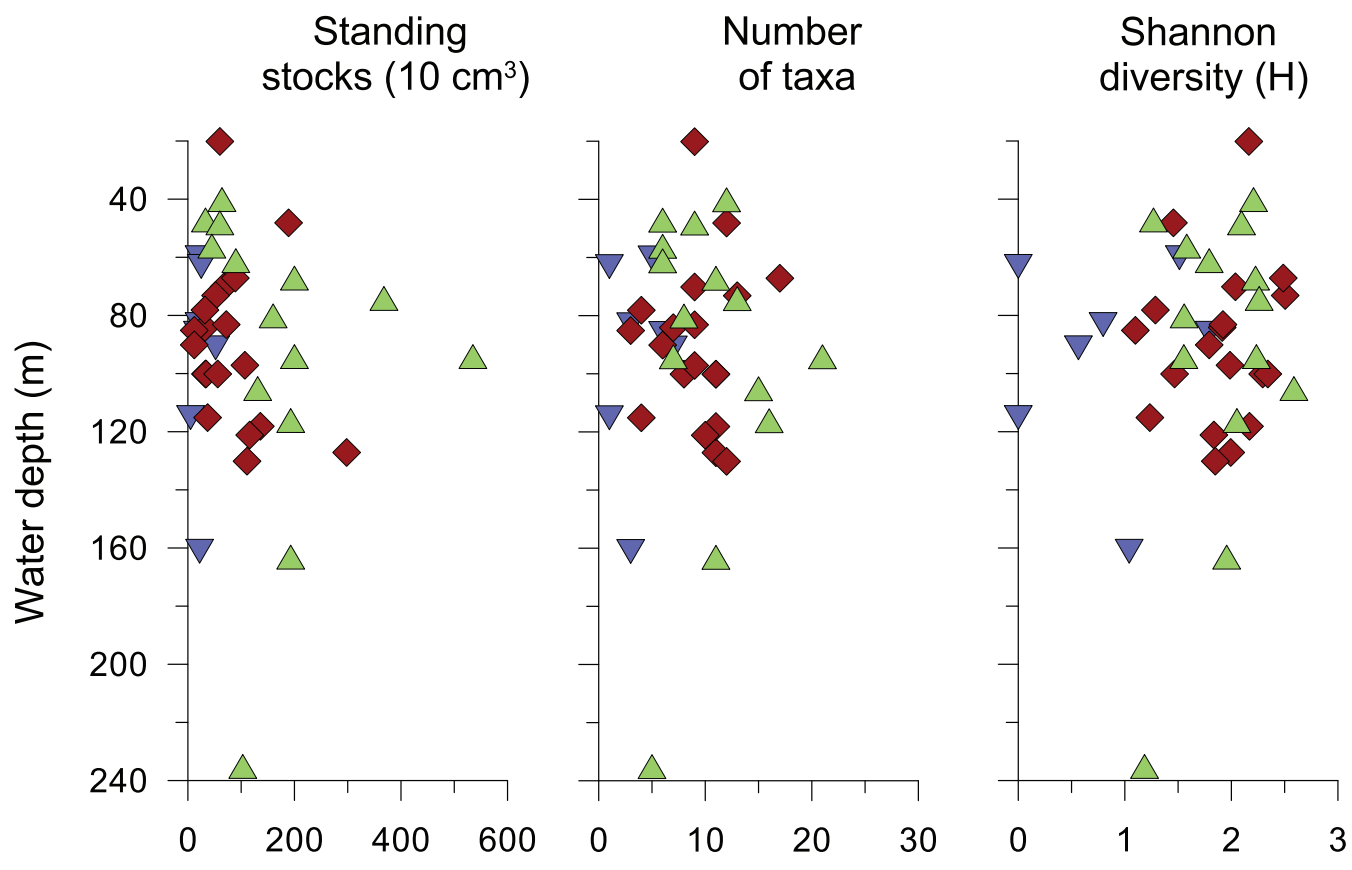

\section{Benthic foraminifera with empty tests}
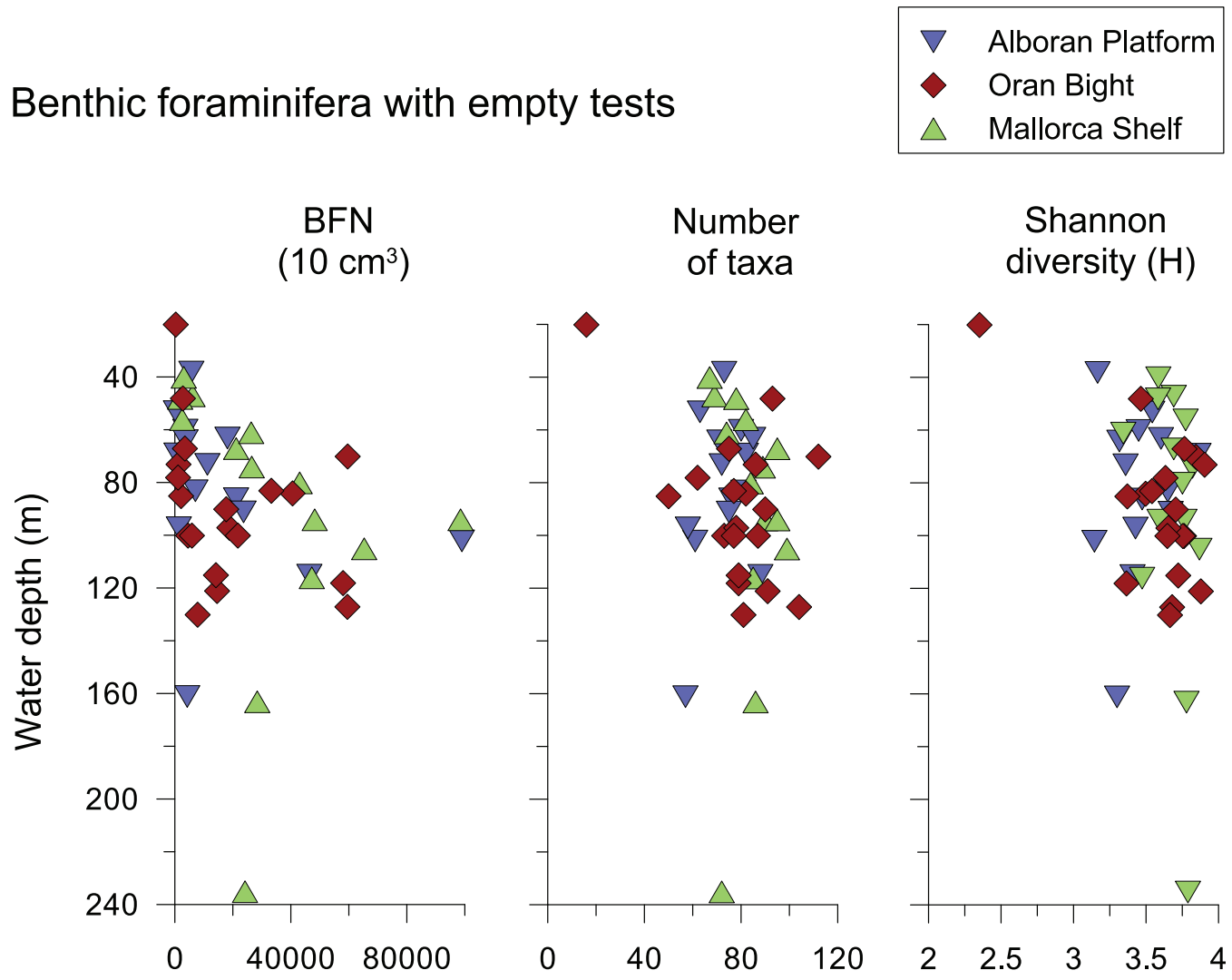

FIGURE 5. Standing stocks per $10 \mathrm{~cm}^{3}$ in the first centimetre of the sediment, number of individual taxa and Shannon diversity $(\mathrm{H})$ for the Rose Bengal-stained foraminiferal assemblages (top) and benthic foraminiferal number (BFN) per $10 \mathrm{~cm}^{3}$, number of taxa and Shannon diversity for the dead foraminiferal assemblages (bottom) in the studied areas versus water depth. 


\section{Alboran Platform}
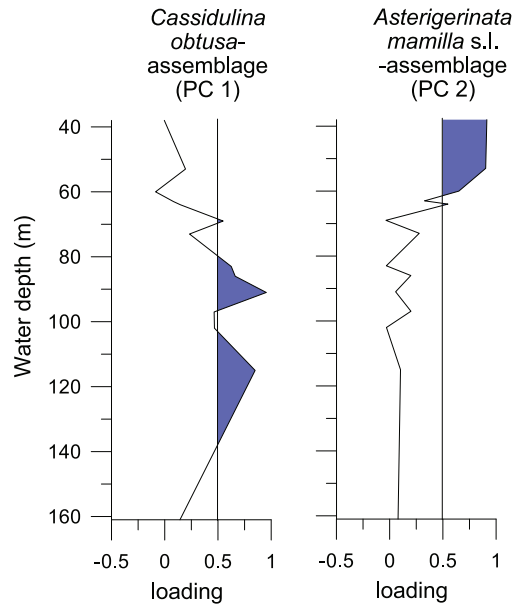

Elphidium complanatum assemblage (PC 3) pseudoungerianusassemblage (PC 4)

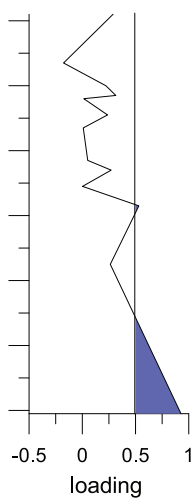

Oran Bight
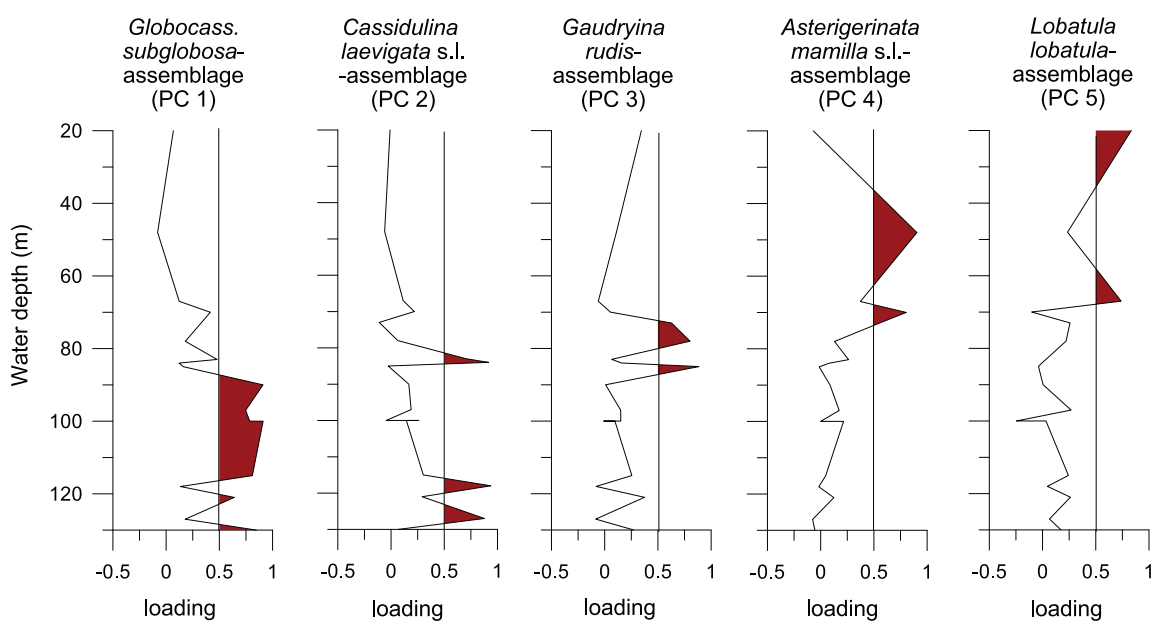

Mallorca Shelf
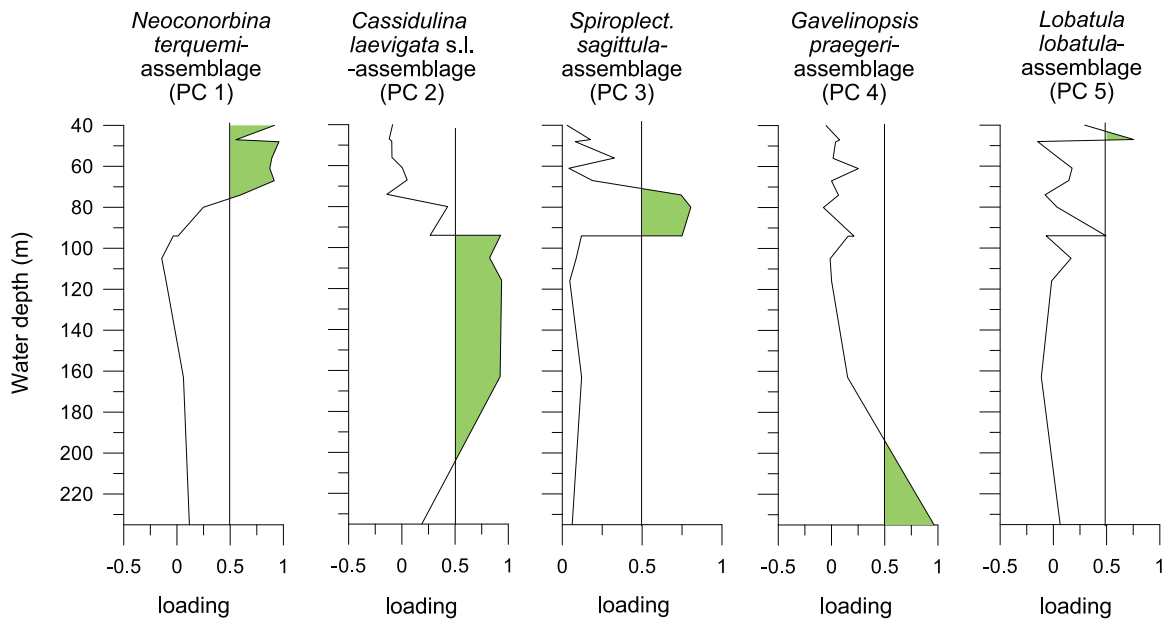

FIGURE 6. Principal Component Analysis (PCA) in Q-Mode for the Alboran Platform (top), Oran Bight (middle) and Mallorca Shelf (bottom) dead assemblages in the surface samples. PC loadings higher than 0.5 are defined as significant as suggested by Malmgren and Haq (1982) and are filled. See also Table 3. 
TABLE 3. Summary of Principal Component Analysis (PCA) in Q-Mode of the dead assemblages in the surface samples from the Alboran Platform, Oran Bight and Mallorca Shelf. Given are the dominant species and the most important associated species with their scores. Further, the explained variance for the principal components (PCs) is listed.

\begin{tabular}{|c|c|c|c|}
\hline \multicolumn{4}{|c|}{ Alboran Platform } \\
\hline$P C$ axis & $\begin{array}{c}\text { Variance } \\
{[\%]}\end{array}$ & Species & Score \\
\hline 1 & 56.8 & $\begin{array}{l}\text { Cassidulina obtusa } \\
\text { Globocassidulina subglobulosa } \\
\text { Gavelinopsis praegeri }\end{array}$ & $\begin{array}{l}3.44 \\
2.96 \\
1.65\end{array}$ \\
\hline 2 & 16.8 & $\begin{array}{l}\text { Asterigerinata mamilla s.I. } \\
\text { Elphidium complanatum } \\
\text { Lobatula lobatula }\end{array}$ & $\begin{array}{l}4.47 \\
1.91 \\
1.59\end{array}$ \\
\hline 3 & 8.4 & $\begin{array}{l}\text { Elphidium complanatum } \\
\text { Cibicides refulgens } \\
\text { Cibicidoides pseudoungerianus }\end{array}$ & $\begin{array}{l}3.28 \\
3.18 \\
1.36\end{array}$ \\
\hline 4 & 7.7 & $\begin{array}{l}\text { Cibicidoides pseudungerianus } \\
\text { Cassidulina obtusa } \\
\text { Asterigerinata mamilla s.I. }\end{array}$ & $\begin{array}{l}4.71 \\
1.48 \\
1.26\end{array}$ \\
\hline \multicolumn{4}{|c|}{ Oran Bight } \\
\hline PC axis & $\begin{array}{c}\text { Variance } \\
{[\%]}\end{array}$ & Species & Score \\
\hline 1 & 42.2 & $\begin{array}{l}\text { Globocassidulina subglobulosa } \\
\text { Cassidulina obtusa } \\
\text { Spiroplectinella sagittula }\end{array}$ & $\begin{array}{l}5.03 \\
2.03 \\
1.42\end{array}$ \\
\hline 2 & 15.1 & $\begin{array}{l}\text { Cassidulina laevigata s.I. } \\
\text { Globocassidulina oblonga }\end{array}$ & $\begin{array}{l}5.59 \\
2.39\end{array}$ \\
\hline 3 & 11.1 & $\begin{array}{l}\text { Gaudryina rudis } \\
\text { Lobatula lobatula } \\
\text { Eponides concameratus }\end{array}$ & $\begin{array}{l}3.36 \\
2.52 \\
2.20\end{array}$ \\
\hline 4 & 8.0 & $\begin{array}{l}\text { Asterigerinata mamilla s.l. } \\
\text { Rosalina macropora } \\
\text { Discorbinella bertheloti }\end{array}$ & $\begin{array}{l}5.26 \\
1.89 \\
1.64\end{array}$ \\
\hline 5 & 5.8 & $\begin{array}{l}\text { Lobatula lobatula } \\
\text { Neoconorbina terquemi } \\
\text { Cibicidoides pseudoungerianus }\end{array}$ & $\begin{array}{l}4.37 \\
2.31 \\
1.96\end{array}$ \\
\hline
\end{tabular}

erally correspond to the recent assemblages in the study areas. It has been further shown that the assemblages of the latest glacial period and the early Holocene on the Alboran Platform and the Mallorca Shelf consist of a higher number of epifaunal species recently found in high energy environments (see Milker et al., 2009, and references therein), reflecting high energy conditions during a lower relative sea-level (Milker et al., 2011). On the Mallorca shelf, the relative sea-level rise is clearly reflected in the increasing numbers of Cassidulina laevigata s.l. and the accumulation of finer-grained substrate (Milker et al., 2011), while on the Oran Bight and the Alboran Platform the environmental conditions during the Holocene should have been almost similar to the recent conditions.

\section{SYSTEMATIC BENTHIC FORAMINIFERAL DESCRIPTIONS}

Order FORAMINIFERIDA von Eichwald, 1830 Suborder TEXTULARIINA

Delage and Herouard, 1896

Family BATHYSIPHONIDAE Avnimelech, 1952 
TABLE 3 (continued).

\begin{tabular}{|c|c|c|c|}
\hline \multicolumn{4}{|c|}{ Mallorca Shelf } \\
\hline$P C$ axis & $\begin{array}{c}\text { Variance } \\
{[\%]}\end{array}$ & Species & Score \\
\hline 1 & 35.1 & $\begin{array}{l}\text { Neoconorbina terquemi } \\
\text { Asterigerinata mamilla s.I. } \\
\text { Lobatula lobatula }\end{array}$ & $\begin{array}{l}5.18 \\
3.71 \\
1.45\end{array}$ \\
\hline 2 & 25.9 & $\begin{array}{l}\text { Cassidulina laevigata s.I. } \\
\text { Bulimina elongata } \\
\text { Hyalinea balthica }\end{array}$ & $\begin{array}{l}5.72 \\
2.10 \\
1.45\end{array}$ \\
\hline 3 & 14.2 & $\begin{array}{l}\text { Spiroplectinella sagittula } \\
\text { Asterigerinata mamilla s.I. } \\
\text { Lobatula lobatula }\end{array}$ & $\begin{array}{l}5.34 \\
1.66 \\
1.54\end{array}$ \\
\hline 4 & 7.9 & $\begin{array}{l}\text { Gavelinopsis praegeri } \\
\text { Globocassidulina subglobulosa } \\
\text { Cassidulina obtusa }\end{array}$ & $\begin{array}{l}5.23 \\
1.91 \\
1.86\end{array}$ \\
\hline 5 & 7.4 & $\begin{array}{l}\text { Lobatula lobatula } \\
\text { Textularia calva } \\
\text { Gaudyrina rudis }\end{array}$ & $\begin{array}{l}4.62 \\
1.71 \\
1.38\end{array}$ \\
\hline
\end{tabular}

Genus RHABDAMMINELLA de Folin, 1887

Rhabdamminella cylindrica (Brady, 1882)

Figure 9.1

1882 Marsipella cylindrica Brady: p. 714

1884 Marsipella cylindrica Brady; Brady, p. 265, PI. 24, figs. 20-22

1910 Marsipella cylindrica Brady; Cushman, p. 30, text-figs. 15,16

1918 Marsipella cylindrica Brady; Cushman, p. 24, pl. 9, figs. 8,9

1931 Marsipella cylindrica Brady; Wiesner, p. 79 , pl. 3, fig. 27

1988 Rhabdamminella cylindrica (Brady); Loeblich and Tappan, p. 4, pl. 14, figs. 2, 3 [cop. Brady, 1884, figs. 21, 22]

1994 Marsipella cylindrica Brady; Jones, p. 34, pl. 24, figs. 20-22 [cop. Brady, 1884, figs. 20-22]

Remarks: The wall is composed of cemented sponge spicules, parallel to the side of the test in a more or less overlapping arrangement. The test is an elongate slender tube of constant diameter. The aperture is on the open end of the test.

Family PSAMMOSPHAERIDAE Haeckel, 1894 Subfamily PSAMMOSPHAERINAE Haeckel, 1894

Genus PSAMMOSPHAERA Schulze, 1875
Psammosphaera fusca Schulze, 1875

Figure 9.2-3

1875 Psammosphaera fusca Schulze: p. 113, pl. 2 , fig. 8 a-f

1910 Psammosphaera fusca Schulze; Cushman, p. 35-36, figs. 25-28

1910 Psammosphaera parva Flint; Cushman, pp. 36-37, figs. 29,30

1931 Psammosphaera fusca Schulze; Wiesner, p. 79 , pl. 4 , fig. 32

1988 Psammosphaera fusca Schulze; Loeblich and Tappan, p. 6, pl. 19, figs. 2, 3

1993 Psammosphaera fusca Schulze; Sgarrella and Moncharmont Zei, p. 151, pl. 1, fig. 14

1994 Psammosphaera fusca Schulze; Jones, p. 31, pl. 18, figs. 1-8

2005 Psammosphaera fusca Schulze; Rasmussen, p. 54, pl. 1, fig. 1

Remarks: The wall is coarsely agglutinated. The test is free or attached and spherical, with one chamber or more. The species may enclose sponge spicules. Psammosphaera parva was distinguished from Psammosphaera fusca by the spicular construction in Cushman (1910). According to Jones (1994), Psammosphaera parva is here regarded as a junior synonym of $P$. fusca. 
TABLE 4. Statistical output of the Redundancy Analysis (RDA) applied on the dead fauna in the surface samples. For the analysis, binary "dummy" variables for Alboran Platform, Oran Bight and Mallorca Shelf were used as covariables (see Milker et al., 2009).

\begin{tabular}{|c|c|c|c|c|c|c|c|}
\hline & Axis 1 & Axis 2 & Axis 3 & Axis 4 & $\begin{array}{c}\text { Captured } \\
\text { variance } \\
(\%)\end{array}$ & F value & p value \\
\hline eigenvalues & 0.141 & 0.042 & 0.011 & 0.009 & & & \\
\hline species-environment correlations & 0.778 & 0.619 & 0.595 & 0.553 & & & \\
\hline cumulative percentage variance & & & & & & & \\
\hline of species data & 19.0 & 24.7 & 26.2 & 27.4 & & & \\
\hline of species-environment relation & 67.1 & 87.2 & 92.4 & 96.7 & & & \\
\hline \multicolumn{8}{|l|}{ Correlation } \\
\hline water depth & 0.8071 & -0.2602 & 0.1625 & 0.0757 & 12.9 & 6.25 & $<0.0002$ \\
\hline salinity & -0.7063 & -0.1551 & -0.0939 & 0.0479 & 9.9 & 4.62 & $<0.0002$ \\
\hline$>1000 \mu \mathrm{m}$ & -0.4778 & -0.6811 & 0.3586 & -0.3236 & 7.3 & 3.33 & $<0.0058$ \\
\hline chlorophyll a & -0.5153 & 0.4498 & 0.6924 & -0.0721 & 6.9 & 3.13 & $<0.0058$ \\
\hline$<63 \mu \mathrm{m}$ & 0.4628 & 0.3682 & -0.4030 & -0.4219 & 5.4 & 2.39 & $<0.0276$ \\
\hline temperature & -0.2025 & 0.4289 & 0.2573 & -0.6046 & 2.5 & 1.10 & $<0.3348$ \\
\hline
\end{tabular}

Family SACCAMMINIDAE Brady, 1884

Subfamily SACCAMMININAE Brady, 1884

Genus LAGENAMMINA Rhumbler, 1911

Lagenammina difflugiformis (Brady, 1879a)

Figure 9.4

1879a Reophax difflugiformis Brady: p. 51, pl. 4, fig. 3

1910 Proteonina difflugiformis (Brady); Cushman, p. 41 , text-figs. 40,41

1918 Proteonina difflugiformis (Brady); Cushman, p. 47, pl. 21, figs. 1, 2

1931 Proteonina difflugiformis (Brady); Wiesner, p. 82 , pl. 5 , figs. 53,54

1939 Proteonina difflugiformis (Brady); Cushman and McCulloch, p. 39, pl. 1, fig. 5

1945 Proteonina difflugiformis (Brady); Cushman, p. 545 , pl. 71 , fig. 1

1960 Proteonina difflugiformis (Brady); Hofker, p. 235 , pl. A, fig. 7

1988 Lagenammina difflugiformis (Brady); Loeblich and Tappan, p. 6, pl. 21, figs. 7, 8

1992 Reophax difflugiformis Brady; Schiebel, p. 21, pl. 8, fig. 9

1992 Lagenammina difflugiformis (Brady); Wollenburg, p. 15, pl. 2, fig. 4
1994 Lagenammina arenulata (Skinner); Jones, p. 37 , pl. 30 , fig. 5

Remarks: The wall is composed of coarse-grained particles that are strongly cemented together. The test is unilocular and pyriform. The aperture is terminal at the end of a short neck. This species has been assigned to Lagenammina difflugiformis and not to Lagenammina atlantica due the visible short neck (compare Jones, 1994).

Family AMMODISCIDAE Reuss, 1862

Subfamily AMMODISCINAE Reuss, 1862

Genus AMMODISCUS Reuss, 1862

Ammodiscus minimus Hoeglund, 1947

1947 Ammodiscus minimus Hoeglund: p. 124, pl. 8, figs., 5, 10; text-figs. 90, 105, 110

1960 Ammodiscus minimus Hoeglund; Hofker, p. 236 , pl. A, fig. 13

Remarks: The wall is finely agglutinated and reddish-brown in color. The test is small and circular with a rounded periphery. The coils are in a single plane and increasing in size as added. The aperture, at the open end of the undivided tube, is archshaped. The test surface is smooth.

Subfamily TOLYPAMMINIAE Cushman, 1928 Ammolagena clavata (Parker and Jones, in Jones 


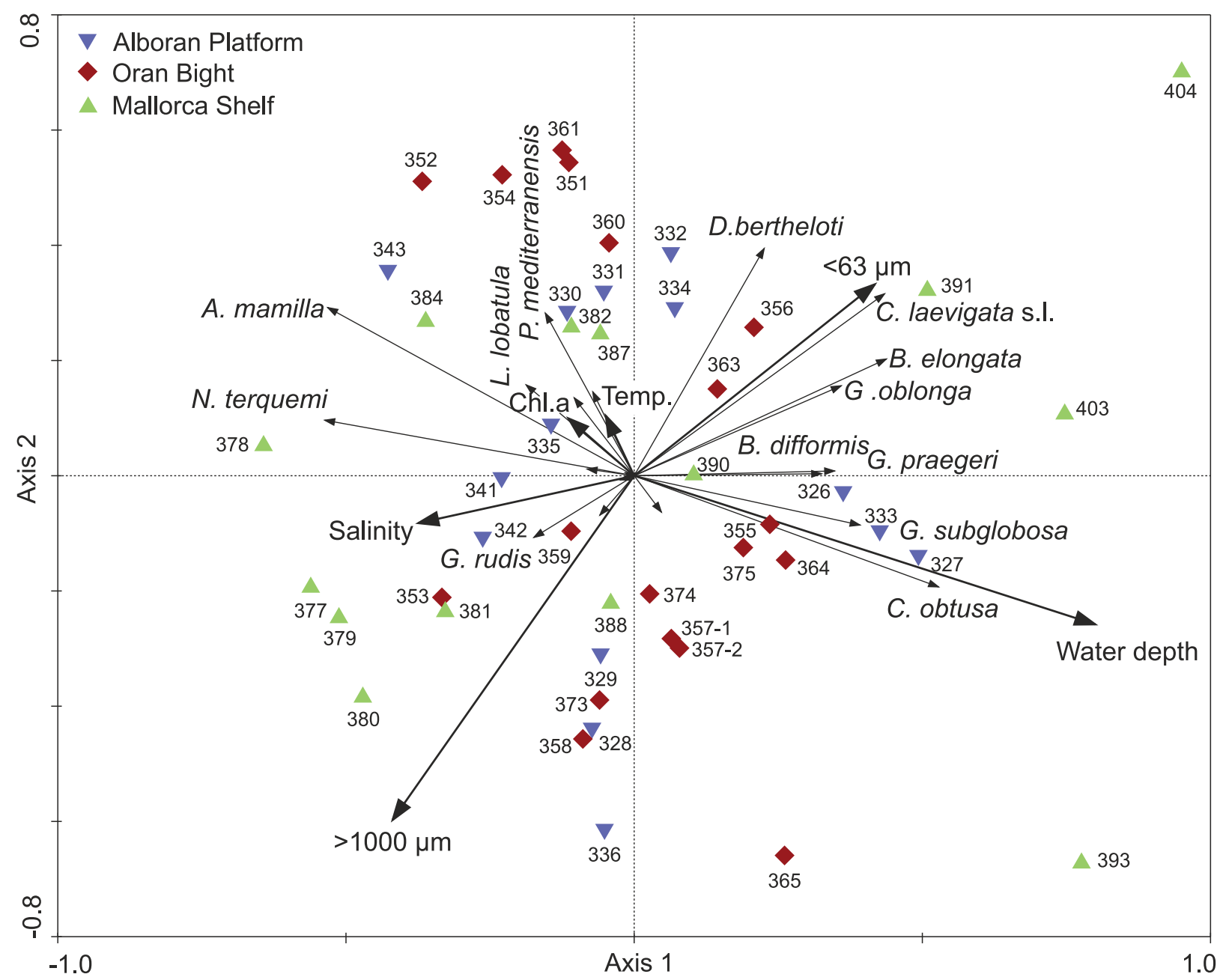

FIGURE 7. Redundancy Analysis (RDA) for the dead assemblages in the surface samples (excluding sample 362-1) (blue triangles: Alboran Platform samples, red diamonds: Oran Bight samples and green up triangles: Mallorca Shelf samples) (see also Table 4). "Location parameters" were included as binary "dummy variables" into analysis and used as covariables to avoid local effects and to extract environmental parameters exerting a similar influence on the benthic foraminiferal variability in all areas (see also Milker et al., 2009). Names from species with very short gradients were removed from the plot for better illustration.

\section{and Parker 1865)}

Figure 9.5

1860 Trochammina irregularis var. clavata Parker and Jones: type reference Jones and Parker, 1860: p. 304

1884 Webbina clavata (Parker and Jones); Brady, p. 349, pl. 14, figs. $12-16$

1910 Ammolagena clavata (Parker and Jones); Cushman, pp. 68-69, text-figs. 86-88

1918 Ammolagena clavata (Parker and Jones); Cushman, p. 89 , pl. 34 , figs. 2-5; pl. 35 , figs. 1-3

1931 Ammolagena clavata (Parker and Jones); Wiesner, p. 94, pl. 11, figs. 131-134
1988 Ammolagena clavata (Parker and Jones); Loeblich and Tappan, p. 11, pl. 36, fig. 16

1991 Ammolagena clavata (Parker and Jones); Cimerman and Langer, p. 16, pl. 3, figs. 13

1994 Ammolagena clavata (Parker and Jones); Jones, p. 46, pl. 41, figs. 12-16 [cop. Brady 1884, figs. 12-16]

2008 Ammolagena clavata (Parker and Jones); Abu-Zied et al., p. 51, pl. 1, fig. 1

Remarks: The wall is finely agglutinated and reddish-brown in color. The attached test consists of a large ovoid proloculus, followed by a narrow rectilinear and tubular chamber. The aperture is terminal and rounded. The test surface is smooth. 


\section{Alboran Platform}
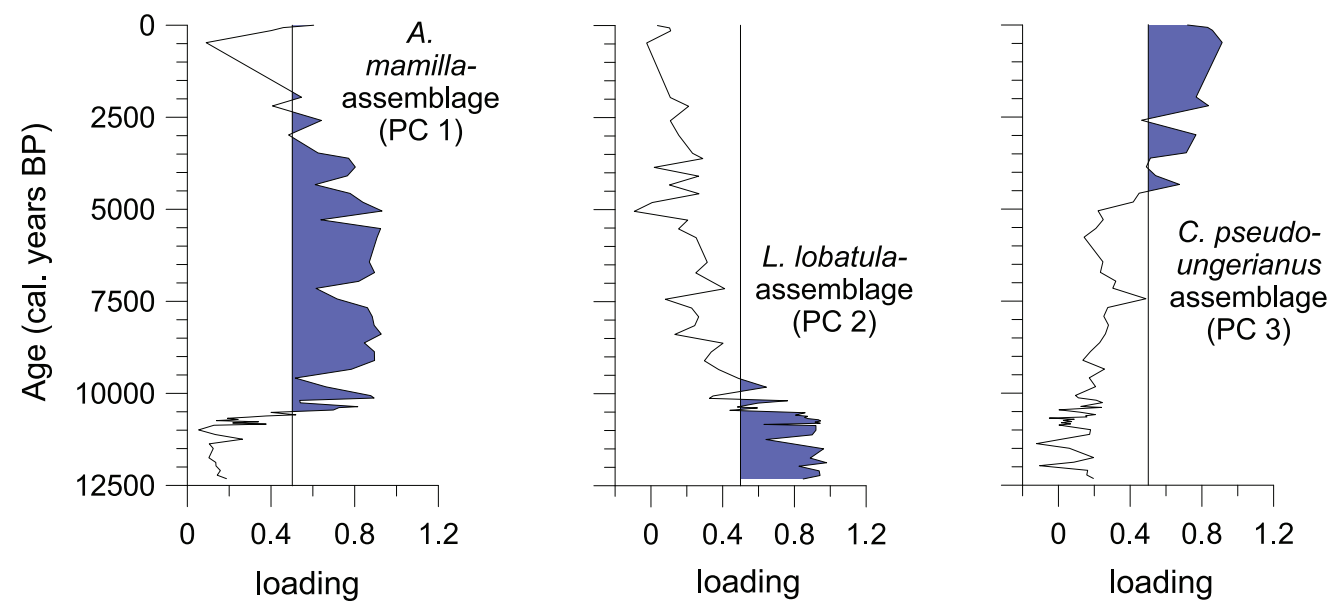

\section{Oran Bight}
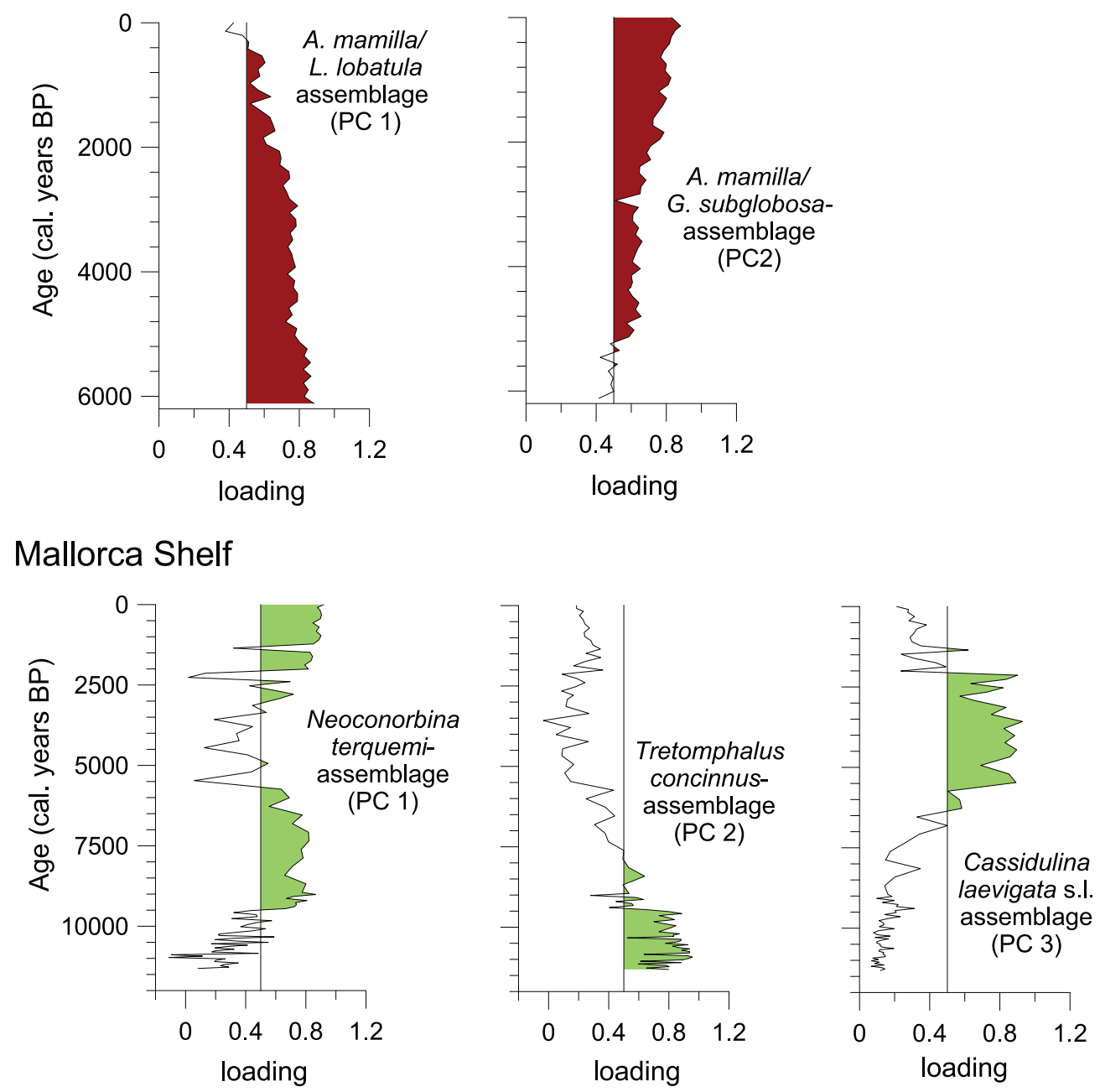

FIGURE 8. Principal Component Analysis (PCA) in Q-Mode for the Alboran Platform (top), Oran Bight (middle) and Mallorca Shelf (bottom) fossil assemblages in the sediment cores. PC loadings higher than 0.5 are defined as significant as suggested by Malmgren and Haq (1982) and are filled. See also Table 5. 
TABLE 5. Summary of Principal Component Analysis (PCA) in Q-Mode of the fossil assemblages in the sediment cores from the Alboran Platform, Oran Bight and Mallorca Shelf. Given are the dominant species and the most important associated species with their scores. Further, the explained variance for the principal components (PCs) is listed.

\begin{tabular}{|c|c|c|c|}
\hline \multicolumn{4}{|c|}{ Core 342-1 (Alboran Platform) } \\
\hline PC Axis & $\begin{array}{c}\text { Variance } \\
{[\%]}\end{array}$ & Species & Score \\
\hline 1 & 37.8 & $\begin{array}{l}\text { Asterigerinata mamilla } \\
\text { Elphidium complanatum } \\
\text { Spirillina vivipara } \\
\text { Brizalina difformis }\end{array}$ & $\begin{array}{l}5.894 \\
5.732 \\
2.389 \\
1.372\end{array}$ \\
\hline 2 & 33.7 & $\begin{array}{l}\text { Lobatula lobatula } \\
\text { Elphidium sp. } 1 \\
\text { Elphidium complanatum forma } \\
\text { tyrrhenianum } \\
\text { Elphidium aculeatum }\end{array}$ & $\begin{array}{l}7.448 \\
4.296 \\
1.883 \\
1.243\end{array}$ \\
\hline 3 & 14.0 & $\begin{array}{l}\text { Cibicidoides pseudoungerianus } \\
\text { Globocassidulina subglobosa } \\
\text { Globocassidulina obtusa } \\
\text { Lobatula lobatula }\end{array}$ & $\begin{array}{l}6.409 \\
2.724 \\
2.434 \\
2.331\end{array}$ \\
\hline \multicolumn{4}{|c|}{ Core 367-1 (Oran Bight) } \\
\hline PC Axis & $\begin{array}{c}\text { Variance } \\
{[\%]}\end{array}$ & Species & Score \\
\hline 1 & 50.9 & $\begin{array}{l}\text { Asterigerinata mamilla } \\
\text { Lobatula lobatula } \\
\text { Quinqueloculina stelligera } \\
\text { Rosalina macropora }\end{array}$ & $\begin{array}{l}4.740 \\
3.895 \\
1.944 \\
1.792\end{array}$ \\
\hline 2 & 44.9 & $\begin{array}{l}\text { Asterigerinata mamilla } \\
\text { Globocassidulina subglobosa } \\
\text { Discorbinella bertheloti } \\
\text { Elphidium complanatum }\end{array}$ & $\begin{array}{l}5.085 \\
2.874 \\
2.826 \\
2.096\end{array}$ \\
\hline \multicolumn{4}{|c|}{ Core 401-1 (Mallorca Shelf) } \\
\hline PC Axis & $\begin{array}{c}\text { Variance } \\
{[\%]}\end{array}$ & Species & Score \\
\hline 1 & 33.6 & $\begin{array}{l}\text { Neoconorbina terquemi } \\
\text { Tretomphalus sp. } 1\end{array}$ & $\begin{array}{l}9.783 \\
2.406\end{array}$ \\
\hline 2 & 34.1 & $\begin{array}{l}\text { Tretomphalus concinnus } \\
\text { Sigmoilinita costata } \\
\text { Spirorbina sp. } 1 \\
\text { Quinqueloculina stelligera }\end{array}$ & $\begin{array}{l}7.798 \\
2.564 \\
2.412 \\
2.369\end{array}$ \\
\hline 3 & 17.5 & $\begin{array}{l}\text { Cassidulina laevigata s.I. } \\
\text { Tretomphalus sp. } 1 \\
\text { Reussella spinulosa } \\
\text { Spirillina vivipara }\end{array}$ & $\begin{array}{l}9.227 \\
2.374 \\
1.642 \\
1.033\end{array}$ \\
\hline
\end{tabular}




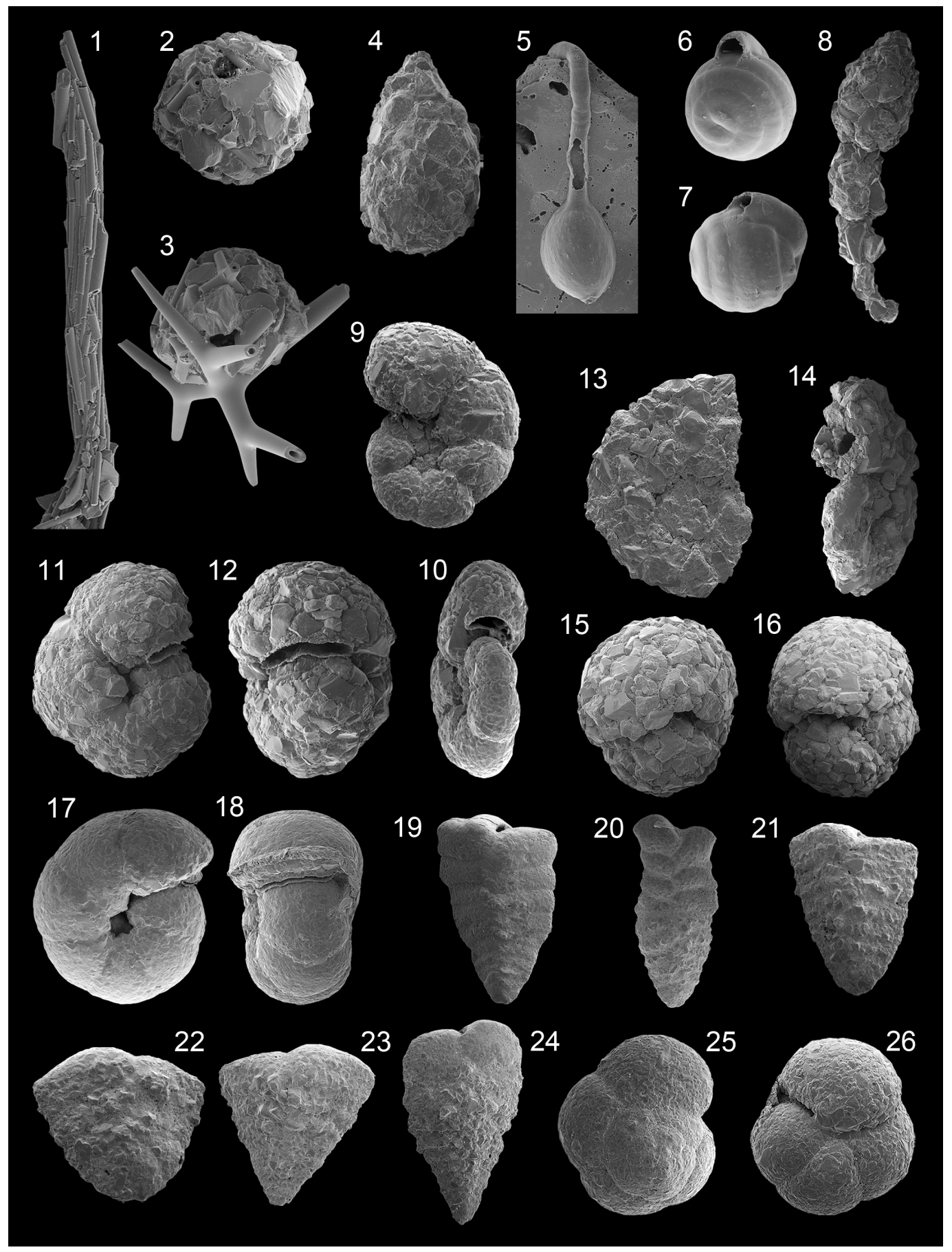

FIGURE 9. 1 Rhabdamminella cylindrica (Brady), 149x, lateral view, 2 Psammosphaera fusca Schulze, 367x, lateral view; 3 P. fusca Schulze, 295x, lateral view; 4 Lagenammina difflugiformis (Brady), 476x, lateral view; 5 Ammolagena clavata (Parker and Jones), 226x, lateral view; 6 Repmanina charoides (Jones and Parker), 510x, apertural edge view; 7 R. charoides (Jones and Parker), 552x, side view; 8 Reophax scorpiurus de Montfort, 119x, lateral view; 9 Cribrostomoides jeffreysii (Williamson), 635x, side view; 10 C. jeffreysii (Williamson), 538x, peripheral view; 11 Labrospira subglobosa (Sars), 355x, side view; 12 L. subglobosa (Sars), 288x, peripheral view; 13 Glaphyrammina americana (Cushman), 269x, side view, 14 G. americana (Cushman), 245x, apertual edge view; 15 Ammosphaeroidina sphaeroidiniformis (Brady), 242x, two chamber side; 16 A. sphaeroidiniformis (Brady), 137x, three chamber side; 17 Alveolophragmium scitulum (Brady), 320x, side view; 18 A. scitulum (Brady), 425x, peripheral view; 19 Spiroplectinella sagittula s.I. (Defrance), 331x, lateral view; 20 S. sagittula s.I. (Defrance), 339x, lateral view; $21 \mathrm{~S}$. sagittula s.I. (Defrance), 587x, lateral view; 22 Spiroplectinella sp. 1, 884x, lateral view; 23 Spiroplectinella sp. 2, 344x, lateral view; 24 Spiroplectinella sp. 2, 374x, lateral view; 25 Ammoglobigerina globigeriniformis (Parker and Jones), 707x, spiral side; 26 A. globigeriniformis (Parker and Jones), 578x, umbilical side; 
Subfamily USBEKISTANIINAE Vyalov, 1968

Genus REPMANINA Suleymanov, in Arapova and Suleymanov 1966

Repmanina charoides (Jones and Parker, 1860)

Figure 9.6-7

1860 Trochammina squamata (Jones and Parker) var. charoides Jones and Parker: p. 304

1884 Ammodiscus charoides (Jones and Parker); Brady, p. 334, pl. 38, figs. 10-16

1918 Glomospira charoides (Jones and Parker); Cushman, pp. 100-101, pl. 36, figs. 10-15 [cop. Brady, 1884, figs. 10-12, 14-16]

1988 Repmanina charoides (Jones and Parker); Loeblich and Tappan, p. 12, pl. 39, figs. 2426 [figs. 25, 26: cop. Brady, 1884, figs. 10, 15]

1991 Repmanina charoides (Jones and Parker); Cimerman and Langer, p. 17, pl. 3, figs. 69

1993 Glomospira charoides (Jones and Parker); Sgarrella and Moncharmont Zei, p. 154, pl. 1, figs. 11,12

1994 Usbekistania charoides (Jones and Parker); Jones, p. 43, pl. 38, figs. 10-16 [cop. Brady, 1884, figs. 10-16]

Remarks: The wall is finely agglutinated and reddish-brown in color. The test is subglobular. The subglobular proloculus is followed by a trochospirally enrolled and undivided second tubular chamber. The aperture is at the open end of the second chamber. The test surface is smooth.

Family HORMOSINIDAE Haeckel, 1894

Subfamily REOPHACINAE Cushman, 1910

Genus REOPHAX de Montfort, 1808

Reophax scorpiurus de Montfort, 1808

Figure 9.8

1808 Reophax scorpiurus de Montfort: p. 331, p. 330 text-fig.

1910 Reophax scorpiurus de Montfort; Cushman, p. 83, text-figs. 114-116

1920 Reophax scorpiurus de Montfort; Cushman, p. 6, pl. 1, figs. 5-7

1988 Reophax scorpiurus de Montfort; Loeblich and Tappan, p. 13, pl. 44, figs. 1-3

1991 Reophax scorpiurus de Montfort; Cimerman and Langer, p. 17, pl. 4, figs. 14
1993 Reophax scorpiurus de Montfort; Sgarrella and Moncharmont Zei, p. 156, pl. 2, figs. 3, 4

2004 Reophax scorpiurus de Montfort; Chendes et al., p. 76, pl. 1, fig. 2

2009 Reophax scorpiurus de Montfort; Avsar et al., p. 134, pl. 1, figs. 3, 4

2009 Reophax scorpiurus de Montfort; Milker et al., p. 215 , pl. 1, fig. 1

Remarks: The wall is coarsely agglutinated and mostly composed of quartz grains, whereas also other particles were observed (Cimerman and Langer, 1991). The test is elongate and arranged in a slightly irregular series. Chambers are subcylindrical and increasing in size as added. The aperture, on a short neck, is terminal and rounded.

Family HAPLOPHRAGMOIDIDAE Maync, 1952

Genus CRIBROSTOMOIDES Cushman, 1910

Cribrostomoides jeffreysii (Williamson, 1858)

Figure 9.9-10

1858 Nonionina jeffreysii Williamson: p. 34, pl. 3, figs. 72,73

1884 Haplophragmium canariense d'Orbigny, sp.; Brady, 1884, p. 310, pl. 35, figs.1-3, 5

1991 Cribrostomoides jeffreysii (Williamson); Alberola et al., p. 80, pl. 1, figs. 1, 5

1991 Labrospira kosterensis Hoeglund; Cimerman and Langer, p. 18, pl. 4, figs. 11-13

1992 Labrospira jeffreysii (Williamson); Schiebel, p. 17, pl. 7, fig. 4

1992 Cribrostomoides jeffreysii (Williamson); Wollenburg, p. 27, pl. 5, figs. 1, 4

1993 Labrospira jeffreysii (Williamson); Hottinger, Halicz and Reiss, p. 29, pl. 2, figs. 5-9

1993 Cribrostomoides jeffreysii (Williamson); Sgarrella and Moncharmont Zei, p. 157, pl. 2 , figs. 8,9

1994 Veleroninoides jeffreysii (Williamson); Jones, p. 41, pl. 35, figs. 1-3, 5 [cop. Brady, 1884, figs. 1-3, 5]

2003 Cribrostomoides jeffreysii (Williamson); Murray, p. 11, fig. 2, no. 5

2005 Cribrostomoides jeffreysii (Williamson); Debenay et al., p. 332, pl. 1, fig. 4

Remarks: The wall is thin and finely to coarsely agglutinated. The test is nearly planispirally enrolled and flattened with a subrounded periph- 
ery. Sutures are radial and slightly depressed. The umbilical region is depressed. The aperture is an equatorial arched slit, slightly above the base of the apertural face and surrounded by a narrow lip.

\section{Genus: HAPLOPHRAGMOIDES Cushman, 1910} Haplophragmoides? sp. 1

Remarks: The wall is coarsely agglutinated. The test is planispirally enrolled and subcircular in lateral view. Five to six chambers are visible, gradually increasing in size as added. Sutures are radial and depressed. The periphery is subrounded. The aperture is an equatorial slit at the base of the apertual face.

Genus LABROSPIRA Hoeglund, 1947

Labrospira subglobosa (Sars, 1869)

Figure 9.11-12

1869 Lituola subglobosa Sars: p. 250

1884 Haplophragmium latidorsatum Bornemann, sp.; Brady, p. 307, pl. 34, figs. 8-10

1910 Haplophragmoides subglobosum (Sars); Cushman, p. 105, text-figs. 162-164

1920 Haplophragmoides subglobosum (Sars); Cushman, p. 45, pl. 8, fig. 5

1939 Haplophragmoides subglobosum (Sars); Cushman and McCulloch, p. 80, pl. 6, figs. 7,8

1960 Labrospira nitida (Goes); Hofker, p. 236, pl. A, fig. 14

1991 Labrospira subglobosa (Sars); Cimerman and Langer, p.18, pl. 5, figs. 1-3

1993 Cribrostomoides subglobosum (Sars); Sgarrella and Moncharmont Zei, p. 157, pl. 2, figs. 15-16

1994 Cribrostomoides subglobosus (Cushman); Jones, p. 40, pl. 34, figs. 8-10 [cop. Brady, 1884, figs. 8-10]

2010 Cribrostomoides subglobosum (Sars); Milker, p. 89, pl. 1, fig. 2

Remarks: The wall is relatively thick and coarsely agglutinated. The test is planispirally enrolled. Chambers increasing in size as added. Sutures are radial and slightly depressed. The periphery is rounded. The aperture is a broad equatorial slit, very slightly above the apertural face and surrounded by a narrow lip.

Family DISCAMMINIDAE Mikhalevich, 1980 Genus GLAPHYRAMMINA Loeblich and Tappan, 1984
Glaphyrammina americana (Cushman, 1910)

Figure 9.13-14

1884 Haplophragmium fontinense Terquem; Brady, p. 305, pl. 34, figs. 1-4

1910 Ammobaculitus americanus Cushman: $p$. 118, text-figs. 184, 185

1920 Ammobaculitus americanus Cushman; Cushman, p. 64, pl. 12, figs. 6, 7

1988 Glaphyrammina americana (Cushman); Loeblich and Tappan, p. 15, pl. 51, figs. 710

1994 Glaphyrammina americana (Cushman); Jones, p. 40, pl. 34, figs. 1-4 [cop. Brady, 1884, figs. 1-4]

Remarks: The wall is coarsely agglutinated. The test is subcircular and flattened. Early chambers are planispirally enrolled with radial or oblique sutures and later chambers are uncoiled. Chambers increasing in size as added. The aperture is an elongate and ovate opening slightly above the base of the final chamber.

\section{Family AMMOSPHAEROIDINIDAE Cushman, 1927 \\ Subfamily AMMOSPHAEROIDININAE Cushman, 1927}

Genus AMMOSPHAEROIDINA Cushman, 1910

Ammosphaeroidina sphaeroidiniformis (Brady, 1884)

Figure 9.15-16

1884 Haplophragmium sphaeroidiniforme Brady: p. 313

1910 Ammosphaeroidina sphaeroidiniformis (Brady); Cushman, p. 128, text-fig. 202

1988 Ammosphaeroidina sphaeroidiniformis (Brady); Loeblich and Tappan, p. 20, pl. 67, figs. 6-7

1993 Ammosphaeroidina sphaeroidiniformis (Brady); Sgarrella and Moncharmont Zei, p. 160 , pl. 4 , fig. 5

Remarks: The test is coarsely agglutinated. The test is globular and in the early stage streptospirally enrolled. Three globular chambers are visible in the adult stage, with one larger chamber on one side and two smaller chambers on the other side. The aperture, at the base of the last chamber, is a low interiomarginal arch.
Family CYCLAMMINIDAE Marie, 1941 Subfamily ALVEOLOPHRAGMIINAE Saidova, 1981

Genus ALVEOLOPHRAGMIUM Shchedrina, 1936 
Alveolophragmium scitulum (Brady, 1881)

Figure 9.17-18

1881 Haplophragmium scitulum Brady: p. 50

1884 Haplophragmium scitulum Brady; Brady, p. 308, pl. 34, figs. 11-13

1910 Alveolophragmium scitulum (Brady); Cushman, p. 103, pl. 6, figs. 153-155 [cop. Brady, 1884, figs. 11-13]

1939 Alveolophragmium scitulum (Brady); Cushman and McCulloch, p. 78, pl. 6, fig. 4

1993 Alveolophragmium scitulum (Brady); Sgarrella and Moncharmont Zei, p. 158, pl. 2, fig. 14

1994 Veleroninoides scitulus (Brady); Jones, $p$. 41, pl. 34, figs. 11-13 [cop. Brady 1884, figs. 11-13]

Remarks: The wall is agglutinated. The test is planispiral enrolled and compressed. Chambers gradually increasing in size as added. The umbilical region is depressed. Sutures are radial and depressed. The periphery is broadly rounded. The aperture is a broad slit at the base of the final chamber and bordered by a narrow lip. The test surface is relatively smooth.

Family SPIROPLECTAMMINIDAE Cushman, 1927 Subfamily SPIROPLECTAMMININAE Cushman, 1927

Genus SPIROPLECTINELLA Kisel'man, 1972

Spiroplectinella sagittula s.I. (Defrance, 1824) Figure 9.19-21

1824 Textularia sagittula Defrance: p. 177

1960 Spiroplectammina sagittula (Defrance); Hofker, p. 237, pl. A, fig. 17

1987 Spiroplectammina wrightii (Silvestri); Alberola et al., p. 304, pl. 1, figs. 11, 12

1987 Textularia sagittula Defrance; Jorissen, $p$. 41, pl. 3, fig. 12

1988 Spiroplectinella wrightii (Silvestri); Loeblich and Tappan, p. 30, pl. 120, figs. 1-10

1991 Spiroplectinella sagittula (d'Orbigny); Cimerman and Langer, p. 19, pl. 6, figs. 5, 6

1991 Spiroplectinella wrightii (Silvestri); Cimerman and Langer, p. 20, pl. 6, figs. 14

1992 Spiroplectinella sagittula (Defrance); Schiebel, p. 26, pl. 6, fig. 14

2002 Spirorutilus sp.; Kaminski et al., p. 171, pl. 1 , figs. 3,4
2005 Textularia sagittula Defrance; Rasmussen, p. 57 , pl. 2, fig. 3

2009 Spiroplectinella sagittula (d'Orbigny); Avsar et al., p. 134, pl. 1, fig. 5

2009 Spiroplectinella sagittula (d'Orbigny); Milker et al., p. 215, pl. 1, figs. 7-9

Remarks: The wall is agglutinated. The test is elongate to subtriangular. The initial stage of the test is planispiral, especially in the microspheric form. Later chambers are biserially arranged and laterally compressed, gradually increasing in size as added. Sutures are depressed and slightly curved. The periphery is acute. The aperture is a low arch at the base of the final chamber. According to Rasmussen (2005) and references therein, Spiroplectinella wrightii (Silvestri) is identical to Spiroplectinella sagittula (Defrance).

\section{Spiroplectinella sp. 1}

Figure 9.22

Remarks: The wall is agglutinated. The test is subtriangular. The initial stage of the test is planispiral, especially in the microspheric form. Chambers are biserially arranged, laterally compressed and increasing in size as added. Sutures are depressed and slightly curved. The periphery is acute. The aperture is a low arch at the base of the apertural face. This species has a more compact test than Spiroplectinella sagittula. It further differs from $S$. sagittula due to the lower number of chambers, whereas a juvenile stage of $S$. sagittula cannot be excluded.

\section{Spiroplectinella sp. 2}

Figure 9.23-24

2002 Textularia sp.; Kaminski et al., p. 171, pl. 1, fig. 7

2004 Textularia sp.; Chendes et al., p. 76, pl. 1, fig. 7

2006 Spiroplectinella sagittula (d'Orbigny); Avsar et al., p. 132, pl. 1, fig. 1

Remarks: The wall is agglutinated. The test is triangular to subtriangular. Chambers are biserially arranged, laterally compressed and rapidly increasing in size as added. Sutures are depressed and slightly curved. The periphery is acute. The aperture is a low arch at the base of the apertural face. This species has a smaller early (planispiral?) stage when compared to Spiroplectinella sagittula s.l. and Spiroplectinella $\mathrm{sp}$. 1. The test is more angular than that of $S$. sagittula s.l. and chambers more rapidly increasing in size as added. 
Family TROCHAMMINIDAE Schwager, 1877

Subfamily TROCHAMMININAE Schwager, 1877 Genus AMMOGLOBIGERINA

Eimer and Fickert, 1899

Ammoglobigerina globigeriniformis

(Parker and Jones, 1865)

Figure 9.25-26

1865 Lituola nautiloidea Lamarck var. globigeriformes Parker and Jones: p. 407, pl. 15, figs. 46,47

1910 Trochammina globigeriniformis (Parker and Jones); Cushman, p. 124, text-figs. 193-

1920 Trochammina globigeriniformis (Parker and Jones); Cushman, p. 78, pl. 16, figs. 5, 6

1987 Trochammina globigeriniformis (Parker and Jones); Alberola et al., p. 305, pl. 2, figs. 4,5

1988 Ammoglobigerina globigeriniformis (Parker and Jones); Loeblich and Tappan, p. 33, pl. 128 , figs. 9,10

1991 Ammoglobigerina globigeriniformis (Parker and Jones); Cimerman and Langer, p. 20, pl. 7, figs. 4-6

1992 Trochammina globigeriniformis (Parker and Jones); Schiebel, p. 63, pl. 7, fig. 9

1993 Trochammina globigeriniformis (Parker and Jones); Sgarrella and Moncharmont Zei, p. 161, pl. 3, figs. 9, 10

Remarks: The wall is relatively thin and coarsely agglutinated. The test is trochospirally enrolled. Chambers are subglobular, rapidly increasing in size as added on the spiral side. Four chambers are visible on the umbilical side. The aperture is an interiomarginal slit at the base of the final chamber on the umbilical side.

Genus TRITAXIS Schubert, 1921

Tritaxis fusca (Williamson, 1858)

1858 Rotalina fusca Williamson: p. 55, pl. 4, figs. 114, 115

1884 Valvulina fusca (Williamson), sp.; Brady, p. 392 , pl. 49 , figs. 13,14

1911 Valvulina fusca (Williamson); Cushman, $p$. 59, text figs. 94, 95 [cop. Brady, 1884, figs. $13,14]$

1964 Tritaxis fusca (Williamson); Hedley, Hurdle and Burdett, pp. 420-421; 425, fig. 2.1
1984 Tritaxis fusca (Williamson); Broennimann and Whittaker; p. 293, figs. 1-10, ?11-14, 19-27

1988 Tritaxis fusca (Williamson); Loeblich and Tappan, p. 33, pl. 128, figs. 1-4 [cop. Broennimann and Whittaker 1984, figs. 710]

Remarks: The wall is finely agglutinated with a few larger grains, imperforate and of yellowish-brown color except for the final chamber that is brighter. The test is slightly concavo-convex and low trochospirally enrolled with a few whorls. Earlier chambers are globular and later chambers are crescentic. Sutures are straight on the umbilical side and slightly backward curved and depressed on the spiral side. The final chamber occupies about one-half of the face of the umbilical side. The aperture is interiomarginal, present on the midway between the umbilicus and the periphery.

Subfamily POLYSTOMAMMININAE Broennimann and Beurlen, 1977

Genus DEUTERAMMINA Broennimann, 1976

Deuterammina dublinensis Broennimann and Whittaker, 1983

Figure 10.1-2

1983 Deuterammina dublinensis Broennimann and Whittaker: p. 353, figs. 21-24, 28-30

1988 Deuterammina dublinensis Broennimann and Whittaker; Loeblich and Tappan, p. 34, pl. 135, figs. 1-5 [cop. Broennimann and Whittacker, 1983, figs. 21-24, 28]

Remarks: The wall is thin and agglutinated. The test is low trochospirally enrolled and slightly concavo-convex. Three whorls are visible on the spiral side. Chambers increasing in size as added. Sutures are nearly radial on both sides and depressed. The periphery is rounded. The primary aperture is interiomarginal and umbilicalextraumbilical. A secondary aperture is present of the inner tip of the final chamber and opens into the umbilical region.

Genus POLYSTOMAMMINA Seiglie, 1965a Polystomammina nitida (Brady, 1881)

Figure 10.3-5

1881 Trochammina nitida Brady: pp. 55-56

1884 Trochammina nitida Brady; Brady, p. 339, pl. 41 , figs. 5,6

1920 Trochammina nitida Brady; Cushman, p. 75, pl. 15, fig. 2 [cop. Brady, 1884, fig. 5] 


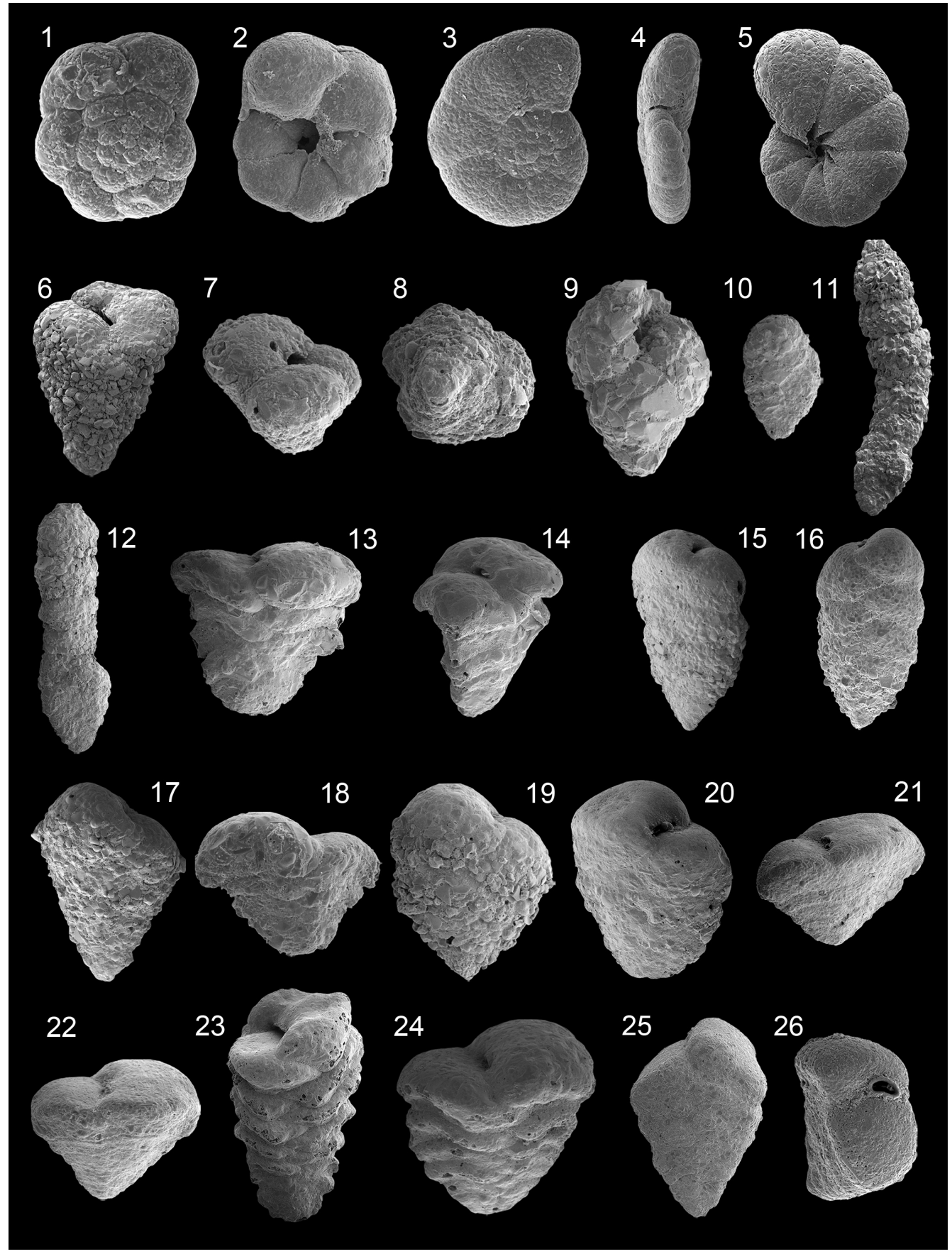

FIGURE 10. 1 Deuterammina dublinensis Broennimann and Whittaker, 890x, spiral side; 2 D. dublinensis Broennimann and Whittaker, 858x, umbilical side; 3 Polystomammina nitida (Brady), 939x, spiral side; 4 P. nitida (Brady), 539x, peripheral view; 5 P. nitida (Brady), 580x, umbilical side; 6 Gaudryina rudis Wright, 275x, lateral view; 7 Gaudryina siciliana Cushman, 1020x, oblique edge view; 8 G. siciliana Cushman, 405x, basal view; 9 Eggerelloides scabrus (Williamson), 626x, lateral view; 10 Bigenerina nodosaria d'Orbigny, 315x, lateral view, juvenile specimen; 11 B. nodosaria d'Orbigny, 207x, lateral view; 12 B. nodosaria d'Orbigny, 242x, lateral view; 13 Sahulia cf. kerimbaensis (Said), 317x, lateral view; 14 S. cf. kerimbaensis (Said), 356x, edge view; 15 Textularia agglutinans d'Orbigny, 157x, lateral view; 16 T. agglutinans d'Orbigny, 256x, lateral view; 17 Textularia calva Lalicker, 246x, lateral view; 18 Textularia conica d'Orbigny, 477x, lateral view; 19 Textularia gramen d'Orbigny, 389x, lateral view; 20 Textularia gramen d'Orbigny, 246x, oblique lateral view; 21 Textularia pala Czjzek, 503x, lateral view; 22 T. pala Czjzek, 366x, lateral view; 23 Textularia pseudorugosa Lacroix, 149x, lateral view, atypical specimen; 24 T. pseudorugosa Lacroix, 278x, lateral view; 25 Siphotextularia concava (Karrer), 360x, lateral view; 26 S. concava (Karrer), 1120x, apertural face. 
1939 Trochammina nitida Brady; Cushman and McCulloch, p. 105, pl. 11, figs. 7-9

1988 Polystomammina nitida (Brady); Loeblich and Tappan, p. 35, pl. 135, figs. 6-9

1994 Polystomammina nitida (Brady); Jones, p. 46, PI. 41, figs. 5, 6 [cop. Brady, 1884, figs. $5,6]$

Remarks: The wall is finely agglutinated. The test is low trochospirally enrolled. Three whorls are visible on the spiral side. Chambers increasing rapidly in size as added. Sutures are gently curved on the spiral side, more radial on the umbilical side and depressed on both sides. The primary aperture is an interiomarginal and arched slit, curving slightly upward on the umbilical side. Secondary apertures are present on the inner tips of the chambers and open into the umbilical region so that relict supplementary openings of the previous chambers are present in the umbilical region.

Family VERNEUILINIDAE Cushman, 1911

Subfamily VERNEUILININAE Cushman, 1911

Genus GAUDRYINA d'Orbigny, 1839a

Gaudryina rudis Wright, 1900

Figure 10.6

1900 Gaudryina rudis Wright: p. 53, pl. 2, fig. 1

1987 Gaudryina rudis Wright; Alberola et al., p. 305 , pl. 2, figs. 8,9

1991 Connemarella rudis (Wright); Cimerman and Langer, p. 23, pl. 8, figs. 1-4

2003 Gaudryina rudis Wright; Murray, p.13, fig. 2, no. 12,13

2009 Connemarella rudis (Wright); Milker et al., p. 215 , pl. 1 , fig. 15

Remarks: The wall is coarsely agglutinated. The test is elongate and conical in lateral view. Chambers are triserially arranged in the early stage. In the later stage, chambers are biserially arranged and more rounded. The aperture is a low slit on the base of the final chamber.

Gaudryina siciliana Cushman, 1936

Figure 10.7-8

1936 Gaudryina siciliana Cushman: p. 9, pl. 2, fig. 1

1993 Sahulia cf. barkeri Hofker; Hottinger, Halicz and Reiss, p. 33, pl. 8, figs. 7-11

1993 Connemarella rudis (Wright); Sgarrella and Moncharmont Zei, p. 167, pl. 4, figs. 6-7

2005 Gaudryina siciliana Cushman; Rasmussen, p. 55 , pl. 1 , figs. 7,8
2009 Gaudryina siciliana Cushman; Milker et al., p. 215 , pl. 1 , figs. 4,5

Remarks: The wall is coarsely agglutinated. The test is low conical, triangular and broader than long in lateral view. Chambers are triserially arranged in the early stage and biserially arranged in the later stage. Sutures are nearly horizontal. The aperture is a low slit at the base of the final chamber and surrounded by a small lip. Despite of the low conical shape and the largely biserial test that is characteristic for the genus Sahulia (Loeblich and Tappan, 1988), this species has been included into the genus Gaudryina due to the triserial early stage.

Family EGGERELLIDAE Cushman, 1937

Subfamily EGGERELLINAE Cushman, 1937

Genus EGGERELLOIDES Haynes, 1973

Eggerelloides scabrus (Williamson, 1858)

Figure 10.9

1858 Bulimina scabra Williamson: p. 65, pl. 5, figs. 136, 137

1960 Eggerella scabra (Williamson); Hofker, p. 236, pl. A, figs. 11, 12

1988 Eggerelloides scabrus (Williamson); Loeblich and Tappan, p. 48, pl. 189, figs. 5-7

1991 Eggerella scabra (Williamson); Alberola et al., p. 80 , pl. 1, fig. 2

1992 Eggerelloides scabra (Williamson); Schiebel, p. 16, pl. 8, fig. 4

1993 Eggerella scabra (Williamson); Sgarrella and Moncharmont Zei, p. 162, pl. 4, fig. 9

1995 Eggerelloides scabrus (Williamson); Coppa and Di Tuoro, p. 166, pl. 1, fig. 5

2003 Eggerelloides scaber (Williamson); Murray, p. 13, fig. 2, no. 11

2004 Eggerelloides scaber (Williamson); Chendes et al., p. 76, pl. 1, fig. 4

2004 Eggerelloides scaber (Williamson); Mendes et al., p. 178, pl. 1, fig. 3

2005 Eggerelloides scabrus (Williamson); Debenay et al., p. 332, pl. 1, fig. 2

2009 Eggerelloides scabrus (Williamson); Avsar et al., p. 134, pl. 1, fig. 7

2009 Eggerelloides scabrus (Williamson); Frezza and Carboni, p. 55, pl. 1, fig. 8; pl. 2, fig. 10

Remarks: The wall is coarsely agglutinated. The test is subfusiform in lateral view. Chambers are trochospirally arranged in the early stage, and later 
chambers are triserially arranged. Chambers gradually increasing in size as added. The aperture is an interiomarginal arch in the center of the apertural face.

Family TEXTULARIIDAE Ehrenberg, 1838

Subfamily TEXTULARIINAE Ehrenberg, 1838

Genus BIGENERINA d'Orbigny, 1826

Bigenerina nodosaria d'Orbigny, 1826

Figure 10.10-12

1826 Bigenerina nodosaria d'Orbigny: p. 261, pl. 11, figs. 9-12

1884 Bigenerina nodosaria d'Orbigny; Brady, p. 369 , pl. 44 , figs. $14-18$

1911 Bigenerina nodosaria d'Orbigny; Cushman, p. 27, text-figs. 46-48 [cop. Brady, 1884, figs. 14-18]

1960 Bigenerina nodosaria d'Orbigny; Hofker, p. 238, pl. A, figs. 19,20

1987 Bigenerina nodosaria d'Orbigny; Alberola et al., p. 304, pl. 1, fig. 1

1987 Bigenerina nodosaria d'Orbigny; Jorissen, p. 34, pl. 1, fig. 10

1988 Bigenerina nodosaria d'Orbigny; Loeblich and Tappan, p. 48, pl. 191, figs. 1, 2

1991 Bigenerina nodosaria d'Orbigny; Cimerman and Langer, p. 21, pl. 9, figs. 16

1993 Bigenerina nodosaria d'Orbigny; Sgarrella and Moncharmont Zei, p. 164, pl. 4, fig. 12

1994 Bigenerina nodosaria d'Orbigny; Jones, $\mathrm{p}$. 49 , pl. 44, figs. 14-18 [cop. Brady 1884, figs. 14-18]

2002 Bigenerina nodosaria d'Orbigny; Kaminski et al., p. 170, pl. 1, fig. 9

2003 Bigenerina nodosaria d'Orbigny; Murray, p. 11, fig. 2, no. 4

2004 Bigenerina nodosaria d'Orbigny; Chendes et al., p. 76 , pl. 1, fig. 5

2005 Bigenerina nodosaria d'Orbigny; Rasmussen, p. 56, pl. 1, figs. 12, 13

2008 Bigenerina nodosaria d'Orbigny; Abu-Zied et al., p. 51, pl. 1, fig. 6

2009 Bigenerina nodosaria d'Orbigny; Avsar et al., p. 134, pl. 1, fig. 8

2009 Bigenerina nodosaria d'Orbigny; Milker et al., p. 215 , pl. 1 , fig. 3

Remarks: The wall is coarsely agglutinated. The test is elongate and partly curved in lateral view.
Early chambers are biserially arranged, and later chambers are uniserially arranged. The terminal aperture, on a short neck, is rounded in the adult stage.

Genus SAHULIA Loeblich and Tappan, 1985 Sahulia cf. kerimbaensis (Said, 1949)

Figure 10.13-14

1915 cf. Textularia conica d'Orbigny var. corrugata Heron-Allen and Earland: p. 629, pl. 47, figs. $24-27$

1932 cf. Textularia corrugata Heron-Allen and Earland; Cushman, p. 12, pl. 3, figs. 2, 4

1949 cf. Textularia kerimbaensis Said: p. 6, pl. 1, fig. 8 (fide Ellis and Messina, 1940ff)

1993 cf. Sahulia kerimbaensis (Said); Hottinger, Halicz and Reiss, p. 34, pl. 9, figs. 8-12

Remarks: The wall is agglutinated. The test is elongate to subtriangular with a subacute peripheral margin. Chambers increasing in size as added and are broad and low. Early chambers are indistinct triserially, and later chambers are biserially arranged. The fistulose chamberlets are mostly broken. Sutures are depressed and curved. The aperture is a slit at the base of the final chamber and bordered by a lip.

Genus TEXTULARIA Defrance, 1824

Textularia agglutinans d'Orbigny, 1839a

Figure 10.15-16

1839a Textularia agglutinans d'Orbigny: p. 144, pl. 1, figs, 17, 18, 32-34

1884 Textularia agglutinans d'Orbigny; Brady, $\mathrm{p}$. 363 , pl. 43 , figs. $1-3$

1911 Textularia agglutinans d'Orbigny; Cushman, p. 9, text-fig. 10

1932 Textularia agglutinans d'Orbigny; Cushman, p. 10, pl. 2, figs. 5-7

1940 Textularia agglutinans d'Orbigny; Lalicker and McCulloch, p. 117, pl. 13, fig. 2

1960 Textularia agglutinans d'Orbigny; Hofker, p. 237 , pl. A, fig. 18

1987 Textularia agglutinans d'Orbigny; Alberola et al., p. 304, pl. 1, fig. 13; pl. 2, fig. 1

1991 Textularia agglutinans d'Orbigny; Alberola et al., p. 80 , pl. 1, fig. 3

1991 Textularia agglutinans d'Orbigny; Cimerman and Langer, p. 21, pl. 10, figs. 1,2 
1994 Textularia agglutinans d'Orbigny; Jones, $\mathrm{p}$. 48, pl. 43, figs. 1-3 [cop. Brady 1884, figs. 1-3]

Remarks: The wall is agglutinated. The test is biserially arranged, elongate and subrounded in adult stage. Chambers increasing in size as added. Sutures are slightly depressed. The aperture is a low arch at the base of the final chamber. Textularia agglutinans shown in Hottinger, Halicz and Reiss, (1993, p. 36, plate 13, figures 1-9) looks different to that shown by the other authors and the specimens in this work due to the slightly irregular chamber arrangement.

Textularia calva Lalicker, 1935

Figure 10.17

1935 Textularia calva Lalicker: p. 1, pl. 1, figs. 1, 2

1940 Textularia calva Lalicker; Lalicker and McCulloch, p. 120, pl. 13, fig. 6

1958 Textularia calva Lalicker; Parker, p. 254, pl. 1, fig. 4

1991 Textularia bocki (Hoeglund); Cimerman and Langer, p. 21, pl. 10, fig. 6

1993 Textularia calva Lalicker; Sgarrella and Moncharmont Zei, p. 164, pl. 3, fig. 11

2002 Textularia bocki (Hoeglund); Kaminski et al., p. 170, pl. 1, figs. 1, 2

2005 Textularia gramen d'Orbigny; Rasmussen, p. 56 , pl. 1 , fig. 17

2009 Textularia calva Lalicker; Milker et al., p. 215, pl. 1, fig. 12

Remarks: The wall is agglutinated. The test is elongate in lateral view. Chambers are biserially arranged, increasing in size as added. The aperture is a low arch at the base of the final chamber. This species is distinguished from Textularia agglutinans and Textularia gramen by its indistinct or not visible sutures under light microscope. However, indistinct sutures can be also characteristic for $G$. gramen (Cushman, 1911). According to Rasmussen (2005), the systematic of the species assigned to $T$. agglutinans, T. gramen, T. pseudogramen, $T$. bocki and T. calva in the literature needs revision.

Textularia conica d'Orbigny, 1839a

Figure 10.18

1839a Textularia conica d'Orbigny: p. 143, pl. 1 , figs. 19,20

1932 Textularia conica d'Orbigny; Cushman, p. 11, pl. 2, figs. 8-10; pl. 3, figs. 1-3
1940 Textularia conica d'Orbigny; Lalicker and McCulloch, p. 126, pl. 14, fig. 8

1958 Textularia conica d'Orbigny; Parker, p. 254 , pl. 1, figs. 5,6

1991 Textularia conica d'Orbigny; Cimerman and Langer, p. 22, pl. 10, figs. 7-9

1993 Textularia conica d'Orbigny; Sgarrella and Moncharmont Zei, p. 166, pl. 3, figs. 4, 5

2005 Textularia conica d'Orbigny; Rasmussen, p. 56 , pl. 1 , figs. 14,15

Remarks: The wall is agglutinated. The test is triangular and broader than long in lateral view. Chambers are biserially arranged, rapidly increasing in size as added. Sutures are depressed and curved. The peripheral margin is subacute. The aperture is a slit at the base of the final chamber. No fistulose chamberlets are visible. The generic position requires further investigation. According to Loeblich and Tappan (1988), Sahulia species differs from Textularia species by the lower and more conical test as observed for $T$. conica.

Textularia gramen d'Orbigny, 1846

Figure 10.19-20

1846 Textularia gramen d'Orbigny: p. 248, tab. 15, figs. 4-6

1911 Textularia gramen d'Orbigny; Cushman, $\mathrm{p}$. 8, text-figs. 6-9

1940 Textularia gramen d'Orbigny; Lalicker and McCulloch, p. 129, pl. 14, fig. 13

1991 Textularia bocki Hoeglund; Cimerman and Langer, p. 21, pl. 10, fig. 5

2002 Textularia sp.; Kaminski et al., p. 170, pl. 1, fig. 8

2009 Textularia bocki Hoeglund; Avsar et al., p. 134, pl. 1, figs. 9, 10

Remarks: The wall is agglutinated. The test is subtriangular and elongate in lateral view. Chambers are biserially arranged, increasing in size as added. The aperture is a low arch at the base of the final chamber. This species is distinguished from Textularia agglutinans by its less depressed sutures and more coarsely arenaceous test and from Textularia calva by this clearly visible sutures (see also remarks to T. calva). According to Rasmussen (2005), specimens having more chambers and have been therefore assigned to Textularia pseudogramen by other authors has been here regarded as conspecific. 


\section{Textularia pala Czjzek, 1848}

Figure 10.21-22

1848 Textularia pala Czjzek: p. 148, pl. 13, figs. 25-27

1991 Textularia truncata Hoeglund; Cimerman and Langer, p. 22, pl. 12, figs. 1-3

1993 Textularia pala Czjzek; Sgarrella and Moncharmont Zei, p. 166 , pl. 3, fig. 8

2009 Textularia pala Czjzek; Milker et al., p. 215, pl. 1, figs. 13,14

Remarks: The wall is finely agglutinated. The test is triangular in lateral view and subrhomboid in section. Chambers are biserially arranged, broad and low, and increasing in size as added. Sutures are very slightly depressed. The aperture is a low arch at the base of the final chamber. This species is clearly distinguishable from the other Textularia species described here by its smoother test surface and its finer arenaceous wall.

Textularia pseudorugosa Lacroix, 1932 Figure 10.23-24

1932 Textularia pseudorugosa Lacroix: pp. 1920, figs. 19-22

1991 Textularia pseudorugosa Lacroix; Cimerman and Langer, p. 22, pl. 11, figs. 5-8

1993 Textularia pseudorugosa Lacroix; Sgarrella and Moncharmont Zei, p. 166, pl. 3, figs. 6, 7

1995 Textularia pseudorugosa Lacroix; Coppa and Di Tuoro, p. 166, pl. 1, fig. 8

2009 Textularia pseudorugosa Lacroix; Milker et al., p. 215, pl. 1, figs. 10, 11

Remarks: The wall is agglutinated. The test is elongate in lateral view. Chambers are biserially arranged. Sutures are distinct and backwards curved. The periphery is subacute. The aperture is a low slit at the inner margin of the final chamber and bordered by a lip. The generic position needs further investigation. Textularia pseudorugosa in this study differs from Sahulia cf. kerimbaensis by the absence of fistulose chamberlets.

\section{Subfamily SIPHOTEXTULARIINAE Loeblich and Tappan, 1985 \\ Genus SIPHOTEXTULARIA Finlay, 1939 \\ Siphotextularia concava (Karrer, 1868)}

Figure 10.25-26

1868 Plecanium concavum Karrer: p. 129, pl. 1, fig. 3
1884 Siphotextularia concava (Karrer), sp.; Brady, p. 360, pl. 42, figs. 13, 14

1911 Textularia concava (Karrer); Cushman, pp. 22-23, text-fig. 38

1932 Textularia concava (Karrer); Cushman, p. 13, pl. 3, fig. 6

1991 Siphotextularia concava (Karrer); Cimerman and Langer, p. 23, pl. 12, figs. 4-6

1993 Siphotextularia concava (Karrer); Sgarrella and Moncharmont Zei, p. 166, pl. 3, fig. 12

1994 Siphotextularia concava (Karrer); Jones, $\mathrm{p}$. 47, pl. 42, figs. 13, 14 [cop. Brady 1884, figs. 13,14$]$

2005 Siphotextularia concava (Karrer); Rasmussen, p. 58, pl. 2, fig. 6

2009 Siphotextularia concava (Karrer); Milker et al., p. 215, pl. 1, fig. 6

Remarks: The wall is finely agglutinated. The test is subquadriangular in section and subtriangular in lateral view. Chambers are biserially arranged, increasing in size as added. Sutures are depressed and curved. The aperture is an elongate slit at the base of the final chamber and surrounded by a lip.

\section{Siphotextularia flintii (Cushman, 1911)}

Figure 11.1-3

1911 Textularia flintii Cushman: p. 21, text-fig. 36

1987 Siphotextularia flintii (Cushman); Alberola et al., p. 304, pl. 1, figs. 9, 10

2003 Siphotextularia flintii (Cushman); Murray, p. 15 , fig. 3 , no. 11

2009 Siphotextularia concava (Karrer); Avsar et al., p. 134 , pl. 1, fig. 11

Remarks: The wall is finely agglutinated. The test is subtriangular in lateral view. Chambers are biserially arranged and more inflated when compared to Siphotextularia concava. Chambers rapidly increasing in size as added. The periphery is subrounded. The aperture is an elongate slit, slightly above the base of the final chamber, and bordered by a lip.

\section{Family PSEUDOGAUDRYINIDAE Loeblich and Tappan, 1985 \\ Subfamily PSEUDOGAUDRYININAE Loeblich and Tappan, 1985}

Genus PSEUDOCLAVULINA Cushman, 1936 


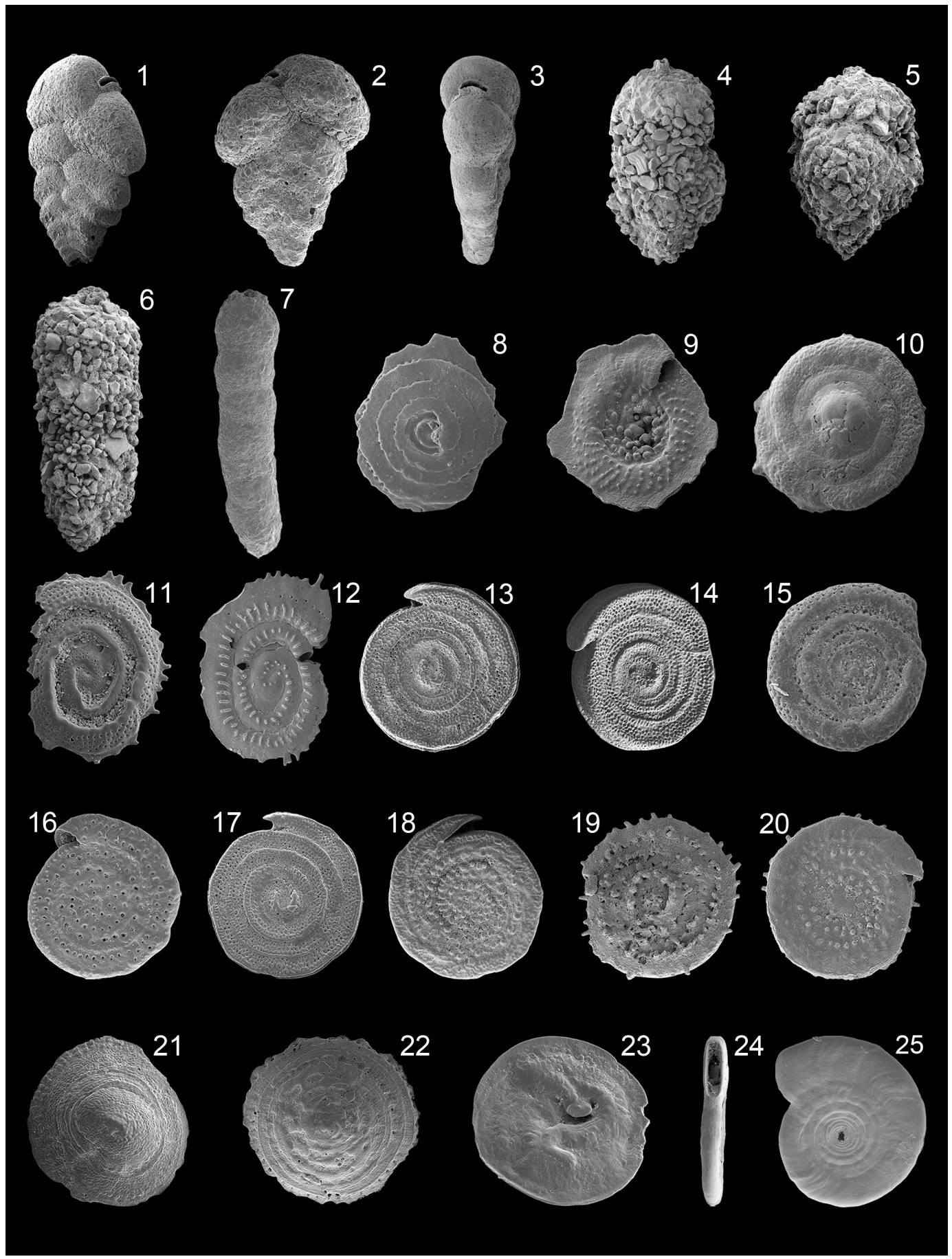

FIGURE 11. 1 Siphotextularia flintii (Cushman), 368x, oblique lateral view; 2 S. flintii (Cushman), 590x, lateral view; 3 S. flintii Cushman, 252x, peripheral view; 4 Pseudoclavulina crustata Cushman, 254x, lateral view, juvenile specimen; 5 Pseudoclavulina crustata Cushman, 291x, lateral view, juvenile specimen; 6 P. crustata Cushman, 399x, lateral view; 7 Clavulina cylindrica (Cushman), 165x, lateral view; 8 Trocholinopsis ornata Sidebottom, 607x, spiral side; 9 T. ornata Sidebottom, 771x, umbilical side; 10 Spirillinid sp. 1, 480x, convex side; 11 Sejunctella cf. lateseptata (Terquem), 683x, spiral side; 12 S. cf. lateseptata (Terquem), 925x, umbilical side; 13 Spirillina limbata Brady, 383x, side view; 14 S. limbata Brady, 415x, side view; 15 Spirillina vivipara Ehrenberg, 684x, side view; 16 S. vivipara Ehrenberg, 655x, side view; 17 Spirillina wrightii Heron-Allen and Earland, 361x, side view; 18 S. wrightii Heron-Allen and Earland, 396x, side view; 19 Spirillina sp. 1, 807x, side view; 20 Spirillina sp. 1, 801x, side view; 21 Patellina corrugata Williamson, 783x, spiral side; 22 P. corrugata Williamson, 685x, spiral side; 23 . corrugata Williamson, 655x, umbilical side; 24 Cornuspira foliacea (Philippi), 318x, peripheral view; 25 C. foliacea (Philippi), 192x, side view. 
Pseudoclavulina crustata Cushman, 1936

Figure 11.4-6

1936 Pseudoclavulina crustata Cushman: p. 19, pl. 3, fig. 12

1958 Pseudoclavulina crustata Cushman; Parker, p. 254, pl. 1, fig. 7

1960 Pseudoclavulina crustata Cushman; Hofker, p. 239, pl. A, figs. 27, 28

1987 Pseudoclavulina crustata Cushman; Jorissen, p. 34, pl. 1, fig. 1

1991 Pseudoclavulina crustata Cushman; Cimerman and Langer, p. 23, pl. 11, figs. 9, 10

1993 Clavulina crustata (Cushman); Sgarrella and Moncharmont Zei, p. 167, pl. 4, fig. 10

2008 Pseudoclavulina crustata Cushman; AbuZied et al., p. 51, pl. 1, fig. 7

Remarks: The wall is coarsely agglutinated. The test is elongate. Early chambers are triserially arranged and triangular in basal view. Later chambers are uniserial and cylindrical. The terminal aperture is a circular and toothless opening on a short neck.

Family VALVULINIDAE Berthelin, 1880

Subfamily VALVULININAE Berthelin, 1880

Genus CLAVULINA d'Orbigny, 1826

Clavulina cylindrica (Cushman, 1922a)

Figure 11.7

1922a Bigenerina cylindrica Cushman: p. 26, pl. 3 , figs. 7, 8

1960 Goesella obscura (Chaster); Hofker, p. 236, pl. A, fig. 15

1993 Bigenerina cylindrica Cushman; Sgarrella and Moncharmont Zei, p. 164, pl. 4, fig. 11

Remarks: The wall is finely agglutinated. The test is elongate. Early chambers are triserially arranged and triangular in basal view. Later chambers are uniserial and cylindrical. The terminal aperture is a circular opening. This species has been assigned to the genus Clavulina due to the triserial arrangement of the early chambers.

Suborder INVOLUTININA Hohenegger and Piller,
1977

Family PLANISPIRILLINIDAE Piller, 1978

Genus TROCHOLINOPSIS Piller, 1983

Trocholinopsis ornata (Sidebottom, 1908)

Figure 11.8-9

1908 Spirillina ornata Sidebottom: p. 9, pl. 2, figs. 7,8
1983 Trocholinopsis porosuturalis Piller; p. 195, pl. 2, figs. $12-23$

1988 Trocholinopsis porosuturalis Piller; Loeblich and Tappan, p. 83, pl. 316, figs. 12-17 [cop. Piller 1983, figs. 13-15, 17-18, 20]

Remarks: The wall is calcareous. The test is a small and a low cone. The spiral side is slightly convex and evolute. The umbilical side is slightly concave. The aperture on the umbilical side is a broad and low opening at the end of the final chamber. Pores are present along the sutures on the spiral side. The umbilical side is ornamented with small, nearly radial and curved pustules and larger pustules in the umbilical region.

Suborder SPIRILLININA Hohenegger and Piller, 1975

Family SPIRILLINIDAE Reuss and Fritsch, 1861 Spirillinid sp. 1

Figure 11.10

1993 Spirillinid genus? sp. A; Hottinger, Halicz and Reiss, p. 75, pl. 87, figs. 1-6

Remarks: The wall is calcareous and imperforate. The test is a low cone. On the convex side, the initial part is composed of a prominent spherical chamber followed by an enrolled tubular chamber. The aperture is on the end of the enrolled tubular chamber. The periphery is provided with rare and short pseudospines and the initial part of the concave side is ornamented with pustules. The test surface is slightly rough. Further study is necessary for the determination of the generic position of this species.

Genus SEJUNCTELLA Loeblich and Tappan, 1957 Sejunctella cf. lateseptata (Terquem, 1875)

Figure 11.11-12

1875 cf. Spirillina lateseptata Terquem: p. 425, pl. 1 , fig. 6

1908 cf. Spirillina vivipara Ehrenberg var. carinata Halkyard; Sidebottom, p. 8, pl. 2, fig. 4

1931 cf. Spirillina lateseptata Terquem; Cushman, p. 6, pl. 1, figs. 12, 13; pl. 2, fig. 1

1988 cf. Sejunctella lateseptata (Terquem); Loeblich and Tappan, p. 83, pl. 318, fig. 8

1991 Sejunctella sp. 2; Cimerman and Langer, p. 23, pl. 13, figs. 6-7

1993 Sejunctella? sp. A; Hottinger, Halicz and Reiss, p. 74, pl. 85, figs. 6-8

Remarks: The wall is hyaline and calcareous. The test is discoidal-ovate and flattened. The prolocu- 
lus is followed by an enrolled second chamber that is separated from the previous whorl by a narrow plate-like area. The periphery is carinate and keeled. The aperture is an opening at the end of the tubular chamber. On the keel, thin pseudospines are present. The convex side is densely perforate. The flat side is almost imperforate but ornamented with oblique ripples.

\section{Genus SPIRILLINA Ehrenberg, 1843 \\ Spirillina limbata Brady, 1879b \\ Figure 11.13-14}

1879b Spirillina limbata Brady: p. 278, pl. 8, fig. 26

1884 Spirillina limbata Brady; Brady, p. 632, pl. 85, figs. 18-21

1991 Spirillina limbata Brady; Cimerman and Langer, p. 24, pl. 14, figs. 1-3

1994 Spirillina limbata Brady; Jones, p. 92, pl. 85 , figs. 18-21 [cop. Brady, 1884, figs. 1821]

Remarks: The wall is calcareous and hyaline. The test is discoidal. The proloculus is followed by an enrolled second tubular chamber. The periphery is bicarinate. The aperture is rounded at the open end of the tubular chamber. The test is densely perforate on both sides. The microspheric specimens shown in Brady (1879b, 1884) differ from the megalospheric specimen shown in Cimerman and Langer (1991) and described here due to the more numerous coils.

Spirillina vivipara Ehrenberg, 1843

Figure 11.15-16

1843 Spirillina vivipara Ehrenberg: p. 422, pl. 3, sec. 7, fig. 41

1884 Spirillina vivipara Ehrenberg; Brady, p. 162, pl. 85, figs. $1-4$

1916 Spirillina vivipara Ehrenberg; Heron-Allen and Earland, p. 268, pl. 42, figs. 21-25

1931 Spirillina vivipara Ehrenberg; Cushman, $p$. 3, pl. 1, figs. 1-4 [fig. 1: cop. Ehrenberg 1843, fig. 41]

1958 Spirillina vivipara Ehrenberg; Parker, p. 264, pl. 3, fig. 4

1960 Spirillina vivipara Ehrenberg; Hofker, p. 252, pl. D, fig. 109

1988 Spirillina vivipara Ehrenberg; Loeblich and Tappan, p. 83, pl. 318, figs. 4-7

1991 Spirillina vivipara Ehrenberg; Cimerman and Langer, p. 24, pl. 14, figs. 4-6
1992 Spirillina vivipara Ehrenberg; Schiebel, p. 69 , pl. 5, fig. 16

1994 Spirillina vivipara Ehrenberg; Jones, p. 92, pl. 85, figs. 1-4 [cop. Brady, 1884, figs. 1-4]

2009 Spirillina vivipara Ehrenberg; Milker et al., p. 216 , pl. 2, fig. 6

Remarks: The wall is calcareous and hyaline. The test is discoidal. The proloculus is followed by an enrolled second tubular chamber. The periphery is subrounded. The aperture is crescentic at the open end of the tubular chamber. The test is perforate on both sides, with slightly smaller pores on one side and larger pores on the other side.

\section{Spirillina wrightii Heron-Allen and Earland, 1930b} Figure 11.17-18

1930b Spirillina wrightii Heron-Allen and Earland: p. 181, pl. 4, figs. 54-58 (fide Ellis and Messina 1940ff)

1958 Spirillina wrightii Heron-Allen and Earland; Parker, p. 264, pl. 3, figs. 1-3

2009 Spirillina limbata Brady; Milker et al., p. 215, pl. 1, fig. 7

Remarks: The wall is calcareous and hyaline. The test is discoidal. The proloculus is followed by an enrolled second tubular chamber. The periphery is bicarinate. The aperture is rounded at the open end of the tubular chamber. The test is densely perforate on one side and ornamented by large pustules on the other side. This species is looks close to Spirillina limbata, but it has large pustules on its nearly imperforate side.

\section{Spirillina sp. 1 \\ Figure 11.19-20}

1951 cf. Spirillina sp.; Phleger and Parker, p. 25, pl. 13 , figs. 5,6

Remarks: The wall is calcareous and hyaline. This test is discoidal. The proloculus is followed by a second chamber. The periphery is subcarinate. The aperture is a simple opening at the end of the tubular chamber. On the keel, relatively short spines, oblique to the periphery, are present. One side is perforate with pseudospine-like features along the suture and has a rough surface. The other side is imperforate with large pustules and has a smooth test surface.

Family PATELLINIDAE Rhumbler, 1906

Subfamily PATELLININAE Rhumbler, 1906

Genus PATELLINA Williamson, 1858

Patellina corrugata Williamson, 1858

Figure 11.21-23 
1858 Patellina corrugata Williamson: p. 46, pl. 3, figs. 86-89

1884 Patellina corrugata Williamson; Brady, p. 634 , pl. 86, figs. $1-7$

1931 Patellina corrugata Williamson; Cushman, p. 11, pl. 2, figs. 6, 7 [cop. Williamson, 1858, fig. 7]

1988 Patellina corrugata Williamson; Loeblich and Tappan, p. 84, pl. 320, figs. 7-14

1991 Patellina corrugata Williamson; Cimerman and Langer, p. 24, pl. 14, figs. 7-12

1993 Patellina corrugata Williamson; Hottinger, Halicz and Reiss, p. 76, pl. 87, figs. 7-11

1994 Patellina corrugata Williamson; Jones, p. 93, pl. 86, figs. 1-7 [cop. Brady, 1884, figs. 1-7]

2003 Patellina corrugata Williamson; Murray, p. 24 , fig. 9 , no. 6,7

Remarks: The test is calcareous. The test is low conical. The proloculus is followed by an enrolled second tubular chamber. The periphery is carinate. All chambers, subdivided by radial septula, are visible on the convex spiral side. Only the final part of the final chamber is visible on the flattened umbilical side. The aperture is a low interiomarginal arch, provided with a T-shaped plate, and opens toward the umbilicus.

Suborder MILIOLINA Delage and Herouard, 1896

Family CORNUSPIRIDAE Schultze, 1854

Subfamily CORNUSPIRINAE Schultze, 1854

Genus CORNUSPIRA Schultze, 1854

Cornuspira foliacea (Philippi, 1844)

Figure 11.24-25

1844 Orbis foliaceus Philippi: p. 147, pl. 24, fig. 26

1865 Cornuspira foliacea (Philippi); Reuss, p. 5, pl. 1, figs. 8, 9

1884 Cornuspira foliacea (Philippi); Brady, p. 199, pl. 11, figs. 5, 6

1917 Cornuspira foliacea (Philippi); Cushman, p. 24, pl. 1, fig. 1; pl. 2, fig. 2; text fig. 4

1929 Cornuspira foliacea (Philippi); Cushman, $p$. 79 , pl. 20, figs. 3-5

1931 Cornuspira foliacea (Philippi); Wiesner, p. 101, pl. 14, fig. 163

1960 Cornuspiroides foliaceum (Philippi); Hofker, p. 240, pl. B, fig. 34

1991 Cornuspira foliacea (Philippi); Cimerman and Langer, p. 24 , pl. 15 , figs. 1-3
1994 Cornuspira foliacea (Philippi); Jones, p. 27, pl. 11, figs. 5, 6 [cop. Brady, 1884, figs. $5,6]$

2005 Cornuspira foliacea (Philippi); Rasmussen, p. 59 , pl. 3 , fig. 3

Remarks: The wall is porcelaneous and imperforate. The test is discoidal and flattened. The proloculus is followed by an enrolled second tubular chamber. The final whorl enlarges continuously. The periphery is rounded. The aperture, at the end of the tubular chamber, is narrow and slightly elongate. The test surface is smooth, and transverse grow lines are present.

Cornuspira involvens (Reuss, 1850) Figure 12.1

1850 Operculina involvens Reuss: p. 6, pl. 1, fig. 20

1884 Cornuspira involvens (Reuss); Brady, p. 200 , pl. 11, figs. 1-3

1917 Cornuspira involvens (Reuss); Cushman, p. 25, pl. 1, fig. 2; pl. 2, fig. 2; text figs. 2, 3

1929 Cornuspira involvens (Reuss); Cushman, p. 80 , pl. 20 , figs. 6,8 [fig. 6: cop. Brady, 1884, fig. 1a]

1931 Cornuspira involvens (Reuss); Wiesner, $p$. 101 , pl. 14 , figs. 161,162

1932 Cornuspira involvens (Reuss); Cushman, p. 67 , pl. 16 , fig. 2

1991 Cornuspira involvens (Reuss); Cimerman and Langer, p. 25, pl. 15, figs. 4-7

1994 Cornuspira involvens (Reuss); Jones, $p$. 26, pl. 11, figs. 1-3 [cop. Brady, 1884, figs. 1-3]

1995 Cyclogira involvens (Reuss); Coppa and Di Tuoro, p. 166, pl. 1, fig. 9

2003 Cornuspira involvens (Reuss); Murray, p. 15 , fig. 4 , no. 5

Remarks: The wall is porcelaneous and imperforate. The test is discoidal, circular in outline and flattened. The proloculus is followed by a second enrolled and undivided tubular chamber that gradually increases in size. The periphery is subrounded. The aperture is rounded at the end of the tubular chamber. The test surface is smooth.

Family FISCHERINIDAE Millett, 1898 Subfamily FISCHERININAE Millett, 1898 Genus TRISEGMENTINA Wiesner, 1920 Trisegmentina compressa Wiesner, 1931

Figure 12.2 


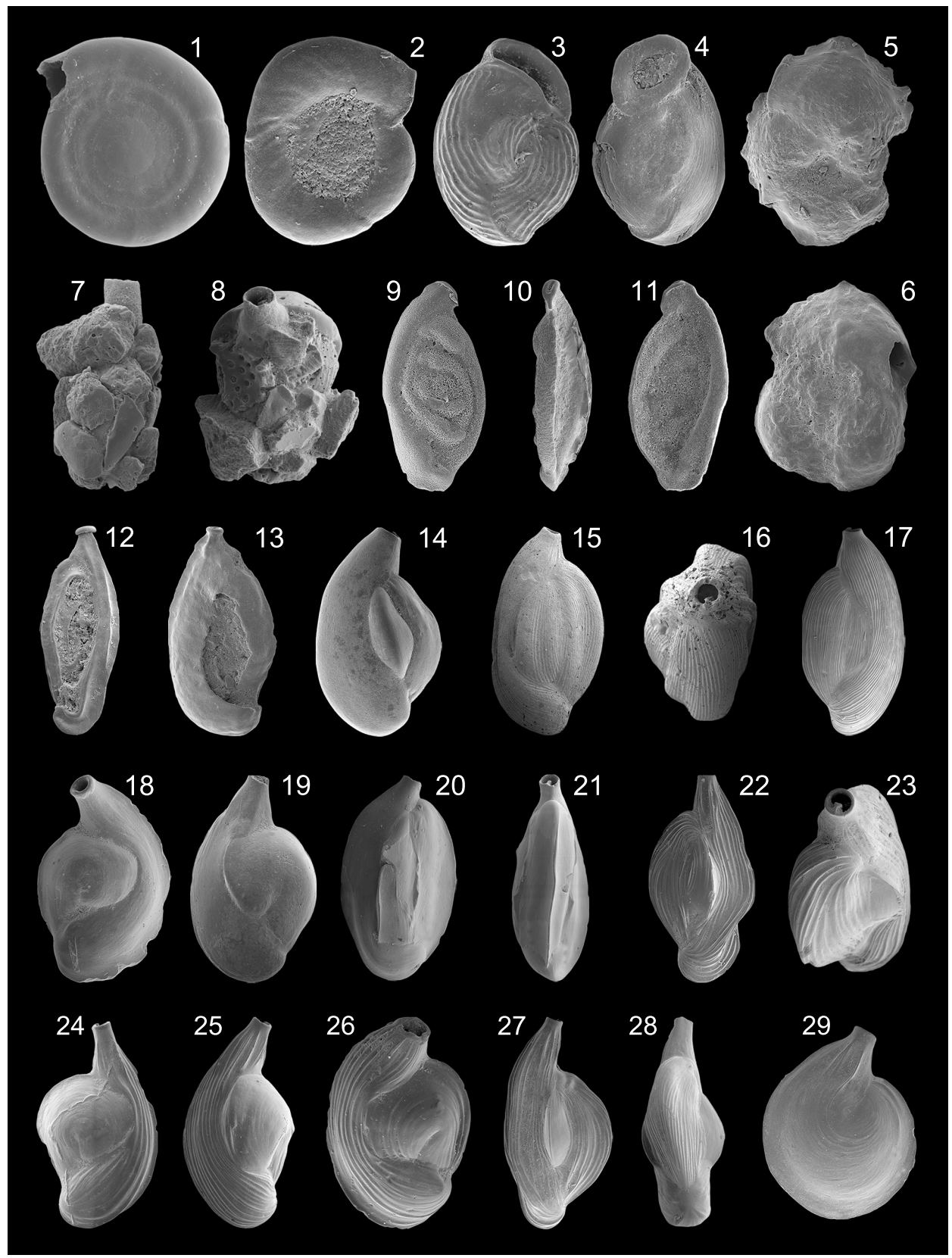

FIGURE 12. 1 Cornuspira involvens (Reuss), 954x, side view; 2 Trisegmentina compressa Wiesner, 729x, side view; 3 Vertebralina striata d'Orbigny, 543x, side view; 4 Wiesnerella auriculata (Egger), 1130x, side view; 5 Nubecularia lucifuga Defrance, 541x, dorsal side; 6 N. lucifuga Defrance, 631x, dorsal side; 7 Nubeculina divaricata (Brady), 685x, lateral view; $8 \mathrm{~N}$. divaricata (Brady), 383x, lateral view; 9 Spirophthalmidium acutimargo (Brady) var. concava (Wiesner), 635x, lateral view; 10 S. acutimargo (Brady) var. concava (Wiesner), 396x, peripheral view; 11 Spirophthalmidium acutimargo (Brady) var. concava (Wiesner), 470x, lateral view; 12 Spirophthalmidium sp. 1, 757x, lateral view; 13 Spirophthalmidium sp. 2, 970x, lateral view; 14 Adelosina dubia (d'Orbigny), 638x, lateral view; 15 Adelosina colomi (Le Calvez and Le Calvez), 103x, four chamber side; 16 A. colomi (Le Calvez and Le Calvez), 137x, apertural view; 17 A. colomi (Le Calvez and Le Calvez), 96x, three chamber side; 18 Adelosina laevigata d'Orbigny, 867x, side view; 19 A. laevigata d'Orbigny, 394x, side view; 20 Adelosina longirostra (d'Orbigny), 233x, four chamber side; 21 A. longirostra (d'Orbigny), 426x, peripheral view; 22 Adelosina mediterranensis (Le Calvez and Le Calvez), 169x, four chamber side; 23 A. mediterranensis (Le Calvez and Le Calvez), 284x, apertural view; 24 A. mediterranensis (Le Calvez and Le Calvez), 408x, side view; 25 A. mediterranensis (Le Calvez and Le Calvez), 268x, side view; 26 A. mediterranensis (Le Calvez and Le Calvez), 422x, side view; 27 A. mediterranensis (Le Calvez and Le Calvez), 153x, three chamber side; 28 A. mediterranensis (Le Calvez and Le Calvez), 163x, peripheral view; 29 Adelosina sp. $1,293 x$, side view. 
1931 Trisegmentina compressa Wiesner: p. 70, pl. 1 , fig. 7

1988 Trisegmentina compressa Wiesner; Loeblich and Tappan, p. 87 , pl. 329, figs. 7-9

1991 Trisegmentina compressa Wiesner; Cimerman and Langer, p. 25, pl. 15, figs. 9-11

1993 Fischerina compressa (Wiesner); Sgarrella and Moncharmont Zei, p. 168, pl. 6, fig. 15

Remarks: The wall is porcelaneous and imperforate. The test is discoidal, subrounded and flattened. The globular proloculus is followed by a planispirally enrolled chamber of about one volution in length and then by two or three enlarging chambers per whorl. Sutures are radial and slightly curved. The aperture, at the end of the final chamber, is bordered by a rim. The test surface is smooth, and some growth ridges may be present.

Family NUBECULARIIDAE Jones, in Griffith and Henfrey 1875

Genus VERTEBRALINA d'Orbigny, 1826 Vertebralina striata d'Orbigny, 1826 Figure 12.3

1826 Vertebralina striata d'Orbigny: p. 283, no. 1

1884 Vertebralina striata d'Orbigny; Brady, $\mathrm{p}$. 187, pl. 12, figs. $12-14$

1917 Vertebralina striata d'Orbigny; Cushman, p. 38 , pl. 22, figs. 3,4

1932 Vertebralina striata d'Orbigny; Cushman, p. 73 , pl. 16, figs. 8-10

1988 Vertebralina striata d'Orbigny; Loeblich and Tappan, p. 87, pl. 330, figs. 17-19

1991 Vertebralina striata d'Orbigny; Cimerman and Langer, p. 25, pl. 16, figs. 1-5

1993 Vertebralina striata d'Orbigny; Hottinger, Halicz and Reiss, p. 43, pl. 23, figs. 8-15

1993 Vertebralina striata d'Orbigny; Sgarrella and Moncharmont Zei, p. 169, pl. 6, fig. 7

1994 Vertebralina striata d'Orbigny; Jones, p. 28, pl. 12, figs. 12-14 [cop. Brady, 1884, figs. 12-14]

Remarks: The wall is porcelaneous and imperforate. The test is flattened and ovate to elongate. Early chambers are low trochospiral arranged and involute, later chambers are uncoiled and rectilinear. Chambers increasing in size as added. The aperture is a long and narrow slit, at the end of the final chamber, and bordered by a rim. The test sur- face is ornamented with longitudinal and elevated ridges.

Genus WIESNERELLA Cushman, 1933b

Wiesnerella auriculata (Egger, 1893)

Figure 12.4

1893 Planispira auriculata Egger: p.245-246, pl. 3, figs $13-15$

1915 Planispirina auriculata (Egger); HeronAllen and Earland, p. 590, pl. 46, figs. 3-7

1929 Planispirina auriculata (Egger); Cushman, p. 93, pl. 22, fig. 3

1932 Planispirina auriculata (Egger); Cushman, p. 72 , pl. 16 , fig. 6

1988 Wiesnerella auriculata (Egger); Loeblich and Tappan, p. 87, pl. 330, figs. 11-13

1993 Wiesnerella auriculata (Egger); Hottinger, Halicz and Reiss, p. 43, pl. 24, figs. 1-4

Remarks: The wall is porcelaneous and imperforate. The test is ovate and flattened. It slightly turns toward the more evolute side of the test. The early stage is planispirally enrolled to low trochospiral. The whorls overlap more on one side than on the other side. Sutures are distinct, and the periphery is carinate. The aperture, at the end of the final chamber, is subrounded and bordered by an elevated and broad rim. The test surface is smooth, and some fine striae may be present.

Family NUBECULARIIDAE Jones, 1875 (in Griffith and Henfrey, 1875)

Subfamily NODOBACULARIINAE Cushman, 1927

Genus NUBECULINA Cushman 1924

Nubeculina divaricata (Brady, 1879b)

Figure 12.7-8

1879b Sagrina divaricata Brady: p. 276, pl. 8, figs. 22-24

1884 Nubeculina divaricata (Brady); Brady, p. 136, pl. 756, figs. $11-16$

1932 Nubeculina divaricata (Brady); Cushman, p. 48 , pl. 11 , figs. 5,6

1988 Nubeculina divaricata (Brady); Loeblich and Tappan, p. 88, pl. 331, figs. 13, 14

1991 Nubeculina divaricata (Brady); Cimerman and Langer, p. 25, pl. 16, figs. 6-10

1994 Nubeculina divaricata (Brady); Jones, p. 88, pl. 756, figs. 11-16 [cop. Brady, 1884, figs. 11-16]

Remarks: The wall is porcelaneous and imperforate. The test is elongate and narrow. The rounded 
aperture is terminal, on a porcelaneous tubular neck and surrounded by a rim. This species incorporates coarse-grained material of different origin, resulting in an agglutinated outer wall. Inwardly projecting teeth as described in Cimerman and Langer (1991) has not been observed.

Subfamily NUBECULARIINAE Jones, in Griffith and Henfrey 1875

Genus NUBECULARIA Defrance, 1825

Nubecularia lucifuga Defrance, 1825

Figure 12.5-6

1825 Nubecularia lucifuga Defrance: p. 210

1917 Nubecularia lucifuga Defrance; Cushman, p. 41 , pl. 8 , fig. 6

1931 Nubecularia lucifuga Defrance; Wiesner, p. 110, pl. 1, figs. 8, 9

1960 Nubecularia lucifuga Defrance; Hofker, p. 244, pl. C, fig. 62

1988 Nubecularia lucifuga Defrance; Loeblich and Tappan, p. 88, pl. 332, figs. 1-3

1991 Nubecularia lucifuga Defrance; Cimerman and Langer, p. 26, pl. 17, figs. 5-7

Remarks: The wall is calcareous and imperforate. The early chambers of the attached test are planispirally arranged. Later chambers are somewhat irregular or rectilinear. The aperture is an elongate slit, irregularly placed and bordered by a weakly developed rim. The test surface is rough.

Family OPHTHALMIDIIDAE Wiesner, 1920

Genus SPIROPHTHALMIDIUM Cushman, 1927

Spirophthalmidium acutimargo (Brady) var. concava (Wiesner, 1913)

Figure 12.9-11

1913 Spiroloculina acutimargo Brady var. concava Wiesner: p. 521, no. 22

1916 Spiroloculina acutimargo var. concava Wiesner; Heron-Allen and Earland, p. 208, pl. 39, figs. 1-3

1929 Spirophthalmidium acutimargo var. concava (Wiesner); Cushman, p. 91, pl. 22, fig. 2 [cop. Heron-Allen and Earland, 1916, figs. 1-3]

1991 Spirophthalmidium acutimargo var. concava Heron Allen and Earland; Rasmussen, p. 363 , fig. 6 , no. 1

1993 Ophthalmidium concava (Wiesner); Sgarrella and Moncharmont Zei, p. 168, pl. 5, figs. 3,4
2008 Spirophthalmidium acutimargo var. concava Heron Allen and Earland; Abu-Zied et al., p. 51 , pl. 1, fig. 9

Remarks: The wall is porcelaneous and imperforate. The test is thin and ovate, with a concave and a convex side. The proloculus is followed by a cornuspirine coil and later by two chambers per whorl. Adjacent chambers are separated by the plate-like keel. The periphery is carinate. The aperture is ovate, terminal and bordered by a lip. The test surface is slightly rough. Our specimens differ from that shown by the other authors by their shorter necks and/ or the distinct lips.

\section{Spirophthalmidium sp. 1}

Figure 12.12

1991 Spirophthalmidium sp. 1; Cimerman and Langer, p. 26, pl. 17, figs. 8-10

Remarks: The wall is porcelaneous. The test is fusiform lateral view and flattened. The proloculus is followed by a cornuspirine coil and later by two chambers per whorl. The periphery is carinate. The ovate aperture is terminal, at the end of a long neck and bordered by a distinct rim.

\section{Spirophthalmidium sp. 2 \\ Figure 12.13}

Remarks: The wall is porcelaneous and imperforate. The test is fusiform in lateral view. The proloculus is followed by a cornuspirine coil and later by two chambers per whorl. The periphery is carinate. The rounded aperture, at the end of a neck, is bordered by a rim.

Family SPIROLOCULINIDAE Wiesner, 1920 Genus ADELOSINA d'Orbigny, 1826

Adelosina colomi (Le Calvez and Le Calvez, 1958) Figure 12.15-17

1958 Quinqueloculina colomi Le Calvez and Le Calvez: p. 176 , pl. 3, figs. 15 , 16; pl. 4, figs. 17-19

Remarks: The wall is porcelaneous. The test is elongate-ovate. The proloculus of the megalospheric test is followed by a complete embraced chamber and a planispirally enrolled second chamber. The third chamber is arranged in nearly $90^{\circ}$ change in coiling plane and later chambers with planes of coiling of $130^{\circ}$ to $160^{\circ}$ apart ("adelosine form"). The peripheral margin is angled. Chambers rapidly increasing in size as added. The rounded aperture is on a neck and provided with a short bifid tooth. The test surface is ornamented with fine longitudinal costae. 
Adelosina dubia (d'Orbigny, 1826)

Figure 12.14

1826 Triloculina dubia d'Orbigny: p. 300, no. 24

1991 Adelosina dubia (d'Orbigny); Cimerman and Langer, p. 27, pl. 18, figs. 5-7

Remarks: The wall is porcelaneous. The test is elongate with a rounded periphery. The chamber arrangement is in "adelosine" form. Three to four chambers are visible from the outerior, rapidly increasing in size as added. The aperture is rounded on a neck and provided with a short tooth. The test surface is smooth.

Adelosina laevigata d'Orbigny, 1826

Figure 12.18-19

1826 Adelosina laevigata d'Orbigny: p. 304, no. 1

1846 Adelosina laevigata d'Orbigny; d'Orbigny, p. 302 , pl. 20 , figs. $22-24$

1988 Adelosina laevigata d'Orbigny; Loeblich and Tappan, p. 90, pl. 337, figs. 5-12

Remarks: The wall is porcelaneous. The test is elongate-ovate. The peripheral margin is acutely angled. Chambers are arranged in "adelosine form." The aperture is rounded, on a neck, bordered by a rim and provided with a short tooth. The test surface is smooth.

Adelosina longirostra (d'Orbigny, 1826)

Figure 12.20-21

1826 Quinqueloculina longirostra d'Orbigny: $p$. 303 , no. 46

1846 Quinqueloculina longirostra d'Orbigny; d'Orbigny, p. 291, pl. 18, figs. 25-27

2005 Adelosina longirostra (d'Orbigny); Debenay et al., p. 332, pl. 1, fig. 10

2005 Adelosina longirostra (d'Orbigny); Rasmussen, p. 60 , pl. 3 , figs. 7,8

Remarks: The wall is porcelaneous. The test is elongate-ovate, but more depressed when compared to other Adelosina species. The chambers are acutely keeled. The aperture is subrounded, on a neck and provided with a short tooth. The test surface is smooth.

Adelosina mediterranensis (Le Calvez and Le Calvez, 1958)

Figure 12.22-28

1958 Quinqueloculina mediterranensis Le Calvez and Le Calvez: p. 177, pl. 4, figs. 29-31
1987 Quinqueloculina mediterranensis Le Calvez and Le Calvez; Alberola et al., p. 306, pl. 3, fig. 8

1991 Adelosina mediterranensis (Le Calvez and Le Calvez); Cimerman and Langer, p. 28, pl. 19, figs. 1-16

1993 Adelosina mediterranensis (Le Calvez and Le Calvez); Sgarrella and Moncharmont Zei, p. 179, pl. 7, figs. 9-11

2005 Adelosina mediterranensis (Le Calvez and Le Calvez); Rasmussen, p. 60, pl. 3, fig. 6

2009 Adelosina mediterranensis (Le Calvez and Le Calvez); Avsar et al., p. 134, pl. 1, fig. 14

2009 Adelosina mediterranensis (Le Calvez and Le Calvez); Milker et al., p. 215, pl. 1, fig. 16

Remarks: The wall is porcelaneous. The test is elongate to ovate. The chambers are arranged in "adelosine form." The periphery is carinate in the juvenile stage and truncate in the adult stage. The aperture is rounded, on a long neck and provided with a short bifid tooth. The test surface is ornamented with numerous longitudinal costae.

\section{Adelosina sp. 1}

Figure 12.29

1991 Adelosina sp. 1; Cimerman and Langer, p. 28, pl. 21, figs. 1, 2, 4 (juvenile specimens)

1994 Miliolid juvenaria; Jones, p. 19, pl. 3, fig. 11

Remarks: The wall is porcelaneous. This species is a juvenile Adelosina form with a megalospheric proloculus followed by an embracing, planispirally enrolled second chamber. The periphery is angled. The aperture is on a neck and provided with a tooth. The test surface may be partly ornamented with costae. No further determination is possible.

\section{Genus SPIROLOCULINA d'Orbigny, 1826} Spiroloculina dilatata d'Orbigny, 1846

Figure 13.1-2

1846 Spiroloculina dilatata d'Orbigny: p. 271, pl. 16, figs. $16-18$

1991 Spiroloculina dilatata d'Orbigny; Cimerman and Langer, p. 30, pl. 22, figs. 5-8

Remarks: The wall is porcelaneous. The test is fusiform and slightly longer than broad in lateral view. The initial stage is composed of a rounded proloculus and a tubular second chamber with one and a half coil in length, the third chamber is arranged with $90^{\circ}$ change of coiling, and later 


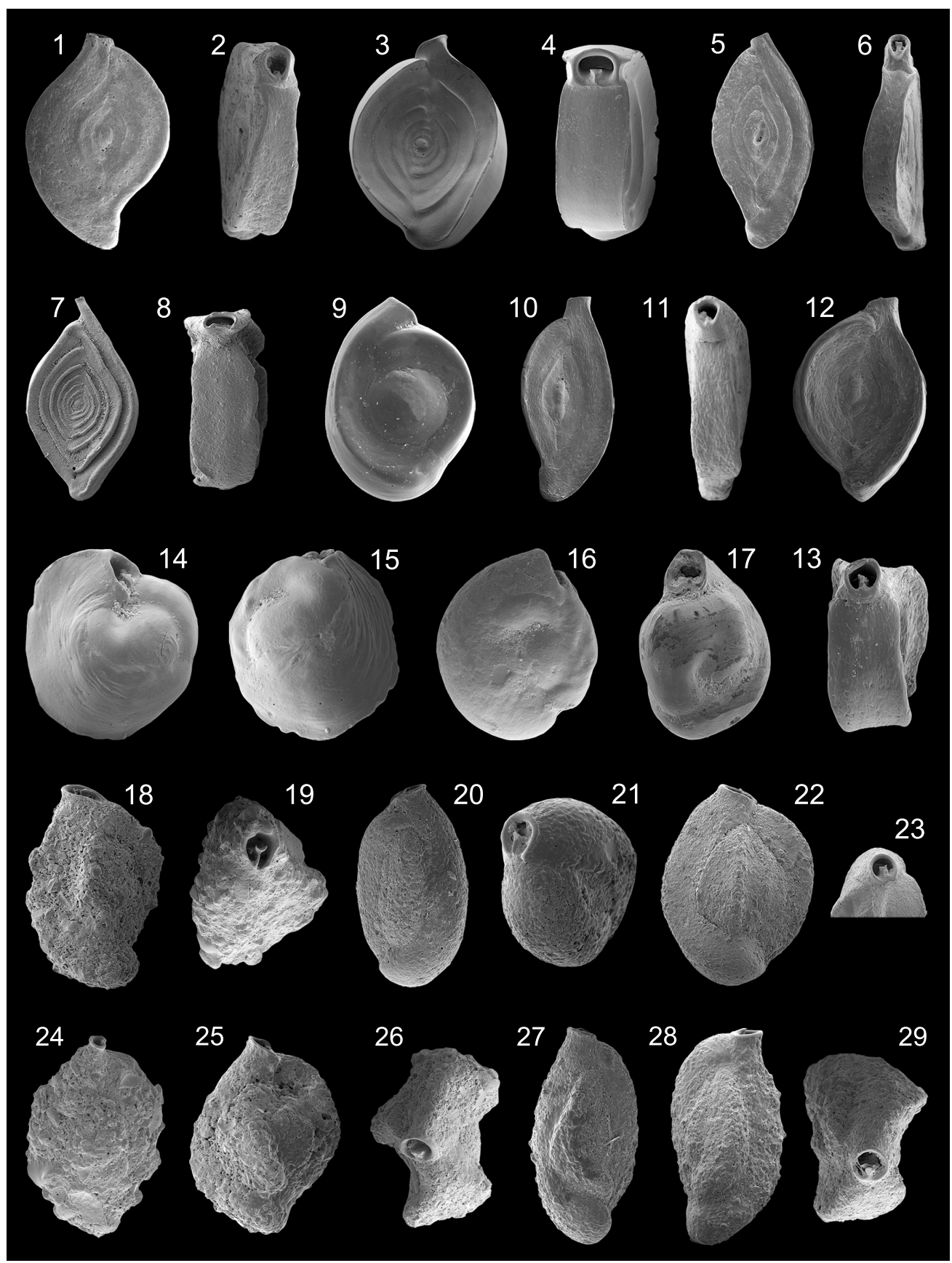

FIGURE 13. 1 Spiroloculina dilatata d'Orbigny, 153x, lateral view; 2 S. dilatata d'Orbigny, 250x, apertural edge view; 3 Spiroloculina excavata d'Orbigny, 196x, lateral view; 4 S. excavata d'Orbigny, 473x, apertural edge view; 5 Spiroloculina cf. rostrata Reuss, 234x, lateral view; 6 S. cf. rostrata Reuss, 261x, apertural edge view; 7 Spiroloculina tenuiseptata Brady, 355x, lateral view; 8 S. tenuiseptata Brady, 209x, apertural edge view; 9 Spiroloculina sp. 1, 1080x, lateral view; 10 Spiroloculina sp. 2, 204x, lateral view; 11 Spiroloculina sp. 2, 270x, apertural edge view; 12 Spiroloculina sp. 3, 322x, lateral view; 13 Spiroloculina sp. 3, 627x, apertural edge view; 14 Miliolid sp. 1, 1000x, side view; 15 Miliolid sp. 1, 952x, side view; 16 Miliolid sp. 2, 832x, side view; 17 Miliolid sp. 2, 1190x, apertural edge view; 18 Siphonaperta agglutinans (d'Orbigny), 341x, side view; 19 S. agglutinans (d'Orbigny), 242x, apertural view; 20 Siphonaperta aspera (d'Orbigny), 599x, side view; 21 S. aspera (d'Orbigny), 449x, apertural view; 22 Siphonaperta dilatata (Le Calvez and Le Calvez), 436x, side view; 23 S. dilatata (Le Calvez and Le Calvez), 365x, apertural view; 24 Siphonaperta horrida (Cushman), 479x, side view; 25 Siphonaperta irregularis (d'Orbigny), 339x, side view; 26 S. irregularis (d'Orbigny), 556x, apertural edge view; 27 Siphonaperta sp. 1, 455x, side view; 28 Siphonaperta sp. 1, 582x, side view; 29 Siphonaperta sp. 1, 456x, apertural edge view. 
chambers are added in a single plane and with one half coil in length ("spiroloculine form"). The periphery is bicarinate. The aperture is subquadratic on a short neck, provided with a tooth and bordered by a rim. The test is ornamented with numerous grooves, leading to a rough surface.

\section{Spiroloculina excavata d'Orbigny, 1846}

Figure 13.3-4

1846 Spiroloculina excavata d'Orbigny: p. 271, pl. 16, figs. 19-21

1960 Spiroloculina excavata d'Orbigny; Hofker, p. 239 , pl. A, fig. 30

1987 Spiroloculina excavata d'Orbigny; Alberola et al., p. 306, pl. 2, fig. 11

1991 Spiroloculina excavata d'Orbigny; Cimerman and Langer, p. 30, pl. 23, figs. 1-3

1993 Spiroloculina excavata d'Orbigny; Sgarrella and Moncharmont Zei, p. 169, pl. 5, fig. 6

2002 Spiroloculina excavata d'Orbigny; Kaminski et al., p. 170, pl. 1, fig. 11

2003 Spiroloculina excavata d'Orbigny; Murray, p. 17 , fig. 4 , no. 13,14

2004 Spiroloculina excavata d'Orbigny; Chendes et al., p. 76, pl. 1, fig. 9

2005 Spiroloculina excavata d'Orbigny; Debenay et al., p. 334, pl. 2, fig. 14

2005 Spiroloculina excavata d'Orbigny; Rasmussen, p. 61, pl. 3, fig. 11

2006 Spiroloculina excavata d'Orbigny; Avsar et al., p. 132, pl. 1, fig. 3

2009 Spiroloculina excavata d'Orbigny; Avsar et al., p. 134 , pl. 1, fig. 16

Remarks: The wall is porcelaneous and imperforate. The test is subelliptical, slightly longer than broad in lateral view and strongly biconcave in end view. The chamber arrangement is in "spiroloculine form." The peripheral margin is truncate. The aperture is elliptical, bordered by a rim and provided with a short bifid tooth. The test surface is smooth.

Spiroloculina cf. rostrata Reuss, 1850

Figure 13.5-6

1850 cf. Spiroloculina rostrata Reuss: p. 18, pl. 4, fig. 7

1993 cf. Spiroloculina rostrata Reuss; Sgarrella and Moncharmont Zei, p. 169, pl. 5, fig. 5
Remarks: The wall is porcelaneous. The test is fusiform in lateral view and slightly biconcave in end view. The chamber arrangement is in "spiroloculine form." The aperture is nearly rounded, bordered a rim, and provided with a relatively long and bifid tooth. The test is ornamented with numerous grooves, leading to a rough surface. Our specimens differ from that shown in Reuss (1850) and Sgarrella and Moncharmont Zei (1993) due to their shorter necks.

Spiroloculina tenuiseptata Brady, 1884 Figure 13.7-8

1884 Spiroloculina tenuiseptata Brady: p. 153, pl. 10 , figs. 5,6

1952 Spiroloculina canaliculata d'Orbigny; Accordi and Selmi, p. 81, pl. 1, figs. 10, 11

1958 Spiroloculina canaliculata d'Orbigny; Parker, p. 257, pl. 1, figs. 26-28

1931 Spiroloculina tenuiseptata Brady; Wiesner, p. 102 , pl. 14, fig. 170

1960 Spiroloculina canaliculata d'Orbigny; Hofker, p. 240, pl. A, fig. 32

1987 Spiroloculina canaliculata d'Orbigny; Alberola et al., p. 306, pl. 2, fig. 16

1991 Spiroloculina tenuiseptata Brady; Cimerman and Langer, p. 31, pl. 24, figs. 6-9

1993 Spiroloculina tenuiseptata Brady; Sgarrella and Moncharmont Zei, p. 169, pl. 5, fig. 7

1994 Spiroloculina tenuiseptata Brady; Jones, $p$. 26 , pl. 10, figs. 5, 6 [cop. Brady, 1884, pl. 10 , figs. 5,6$]$

2002 Spiroloculina tenuiseptata Brady; Kaminski et al., p. 170, pl. 1, fig. 10

2005 Spiroloculina tenuiseptata Brady; Rasmussen, p. 61, pl. 3, fig. 12

Remarks: The wall is porcelaneous. The test is fusiform in lateral view and biconcave in end view. The chamber arrangement is in "spiroloculine form." The peripheral margins of the chambers are elevated. The aperture is elliptical, on a long and narrow neck and bordered by a rim. No tooth was visible. The test surface is rough.

\section{Spiroloculina sp. 1}

Figure 13.9

Remarks: The wall is porcelaneous and imperforate. The test is ovate in lateral view with a relatively broad periphery. The chamber arrangement is in "spiroloculine form." The aperture, at the open 
end of the final chamber, is relatively broad and ovate. The test surface is smooth. This species is likely a juvenile stage of Spiroloculina excavata.

\section{Spiroloculina sp. 2 \\ Figure 13.10-11}

Remarks: The wall is porcelaneous and imperforate. The test is fusiform in lateral view and slightly biconcave in end view. The chamber arrangement is in "spiroloculine form." The aperture is rounded, bordered by a rim and provided with a short bifid tooth. The test is ornamented with numerous grooves, leading to a rough surface.

\section{Spiroloculina sp. 3 \\ Figure 13.12-13}

Remarks: The wall is porcelaneous and imperforate. The test is ovate to fusiform in lateral view and highly biconcave in end view. The aperture is rounded, bordered by a small rim and provided with a relatively short bifid tooth. The test surface is slightly rough.

\section{Family HAUERINIDAE Schwager, 1876 Miliolid sp. 1}

Figure 13.14-15

Remarks: The wall is porcelaneous and imperforate. The test of these small specimens is nearly rounded in lateral view. The peripheral margin is carinate. Three chambers are visible from one side and two from the other side. The terminal aperture is oval, bordered by a rim and provided with a short simple tooth. The test surface is partly ornamented with longitudinal striae. These specimens have been assigned to the Hauerinidae, and not to the Miliolidae, due to the absence of pseudopores as defined by Loeblich and Tappan (1988) for the latter family. No further determination is possible.

Miliolid sp. 2

Figure 13.16-17

Remarks: The wall is porcelaneous and imperforate. The test of these small specimens is ovate in lateral view. The periphery is rounded. Three chambers are visible on both sides. The terminal aperture is ovate. The tooth is long, but mostly broken. These specimens have been assigned to the Hauerinidae, and not to the Miliolidae, due to the absence of pseudopores as defined by Loeblich and Tappan (1988) for the latter family. No further determination is possible.

Subfamily SIPHONAPERTINAE Saidova, 1975 Genus SIPHONAPERTA Vella, 1957

Siphonaperta agglutinans (d'Orbigny, 1839a)

Figure 13.18-19 1839a Quinqueloculina agglutinans d'Orbigny: $p$. 195, pl. 12, figs. 11-13

1929 Quinqueloculina agglutinans d'Orbigny; Cushman, p. 22, pl. 1, fig. 1

1958 Quinqueloculina agglutinans d'Orbigny; Le Calvez and Le Calvez, p. 166, pl. 9, figs. 103, 104

1991 Siphonaperta agglutinans (d'Orbigny); Cimerman and Langer, p. 31, pl. 25, figs. 1-3

1993 Siphonaperta agglutinans (d'Orbigny); Hottinger, Halicz and Reiss, p. 62, pl. 61, figs. 10,11 ; pl. 62 , figs. $1-3$

Remarks: The wall is porcelaneous and imperforate. The test is subcylindrical. The chamber arrangement is "quinqueloculine" (chambers are one half coil in length, earlier chambers are added in coil of planes that are $72^{\circ}$ apart and later chambers are added in coil of planes of $144^{\circ}$ apart so that five chambers are visible from the exterior). The aperture is ovate, bordered by a not agglutinated rim, and provided with a long, slender tooth with bifid termination. The outer coating is agglutinated with particles of different coarse-grained material.

\section{Siphonaperta aspera (d'Orbigny, 1826)}

Figure 13.20-21

1826 Quinqueloculina aspera d'Orbigny: p. 301, no. 11

1958 Quinqueloculina aspera d'Orbigny; Le Calvez and Le Calvez, p. 168, pl. 9, figs. 101, 102

1987 Quinqueloculina aspera d'Orbigny; Jorissen, p. 40 , pl. 3 , fig. 2

1991 Siphonaperta aspera (d'Orbigny); Cimerman and Langer, p. 31, pl. 25, figs. 4-6

1993 Siphonaperta aspera (d'Orbigny); Sgarrella and Moncharmont Zei, p. 185, pl. 6, fig. 12

1995 Siphonaperta aspera dilatata Le Calvez and Le Calvez; Coppa and Di Tuoro, p. 166, pl. 1, fig. 7

2005 Siphonaperta aspera (d'Orbigny); Debenay et al., p. 334, pl. 2, fig. 10

2005 Siphonaperta aspera (d'Orbigny); Rasmussen, p. 61 , pl. 4 , fig. 1

2009 Siphonaperta aspera (d'Orbigny); Frezza and Carboni, p. 55, pl. 1, fig. 21 
Remarks: The wall is porcelaneous and imperforate. The test is ovate in lateral view. The chamber arrangement is "quinqueloculine." Chambers are subrounded. The aperture is ovate, bordered by a not agglutinated rim, and provided with a relatively long, bifid tooth. The outer coating is agglutinated with fine-grained material.

\section{Siphonaperta dilatata (Le Calvez and Le Calvez, 1958)}

Figure 13.22-23

1958 Quinqueloculina aspera d'Orbigny var. dilatata Le Calvez and Le Calvez: p. 169, pl. 11, figs. 119-121

1991 Siphonaperta dilatata (Le Calvez and Le Calvez); Cimerman and Langer, p. 31, pl. 26, figs. 1-3

Remarks: The wall is porcelaneous and imperforate. The test is ovate and nearly as broad as long. The chamber arrangement is "quinqueloculine." Chambers are rounded. The aperture is rounded, bordered by a not agglutinated rim and provided with a short and bifid tooth. The outer coating is agglutinated with fine-grained material.

Siphonaperta horrida (Cushman, 1947) Figure 13.24

1947 Quinqueloculina horrida Cushman: p. 88, pl. 19, fig. 1

1951 Quinqueloculina horrida Cushman; Phleger and Parker, p. 7, pl. 3, fig. 18

1974 Quinqueloculina horrida Cushman; LeRoy and Levinson, p. 6, pl. 2, fig. 1

1993 Siphonaperta horrida (Cushman);

Hottinger, Halicz and Reiss, p. 63, pl. 63, figs. 7-12

Remarks: The wall is porcelaneous and imperforate. The test is ovate with a rounded periphery. The chamber arrangement is "quinqueloculine." Five chambers are poorly visible from the exterior. The small and rounded aperture, at the end of a short neck, is bordered by a not agglutinated rim and provided with a short, bifid tooth. The outer coating is agglutinated with coarse-grained material of different origin.

Siphonaperta irregularis (d'Orbigny, 1826) Figure 13.25-26

1826 Quinqueloculina irregularis d'Orbigny: 302, no. 25
1958 Quinqueloculina irregularis d'Orbigny; Le Calvez and Le Calvez, p. 166, pl. 3, figs. 1, 2

1991 Siphonaperta irregularis (d'Orbigny); Cimerman and Langer, p. 32, pl. 26, figs. 4-6

Remarks: The wall is porcelaneous and imperforate. The test is ovate and nearly as broad as long. The chamber arrangement is "quinqueloculine." The aperture is rounded, bordered by a not agglutinated rim and provided with a short, bifid tooth. The outer coating is agglutinated with coarsegrained material of different origin. It differs from Siphonaperta agglutinans by a different widthlength ratio and from Siphonaperta dilatata by the coarser-grained outer coating and from both by the short tooth.

\section{Siphonaperta sp. 1}

Figure 13.27-29

1991 Siphonaperta sp. 2; Cimerman and Langer, p. 32, pl. 26, figs. 7-9

Remarks: The wall is porcelaneous and imperforate. The test is fusiform in lateral view. The chamber arrangement is "quinqueloculine." The small and rounded aperture, at the end of a short neck, is bordered by a not agglutinated rim and provided with a short, bifid tooth. The outer coating is agglutinated with fine-grained material of different origin.

Siphonaperta sp. 2

Figure 14.1-4

Remarks: The wall is porcelaneous and imperforate. The test is ovate to fusiform in lateral view. The chamber arrangement is "quinqueloculine." The rounded aperture is terminal, at the end of a short neck and provided with a short, bifid tooth. The outer coating is agglutinated with fine-grained material of different origin. This species looks close to Siphonaperta sp.1, but it is generally smaller and has a different width to length ratio.

Subfamily HAUERININAE Schwager, 1876

Genus CYCLOFORINA Luczowksa, 1972

Cycloforina contorta (d'Orbigny, 1846)

Figures 14.5-7

1846 Quinqueloculina contorta d'Orbigny: $p$. 298, pl. 20, figs. 4-6

1929 Quinqueloculina contorta d'Orbigny; Cushman, p. 29, pl. 3, fig. 6 [cop. d'Orbigny, 1846, figs. 4-6] 


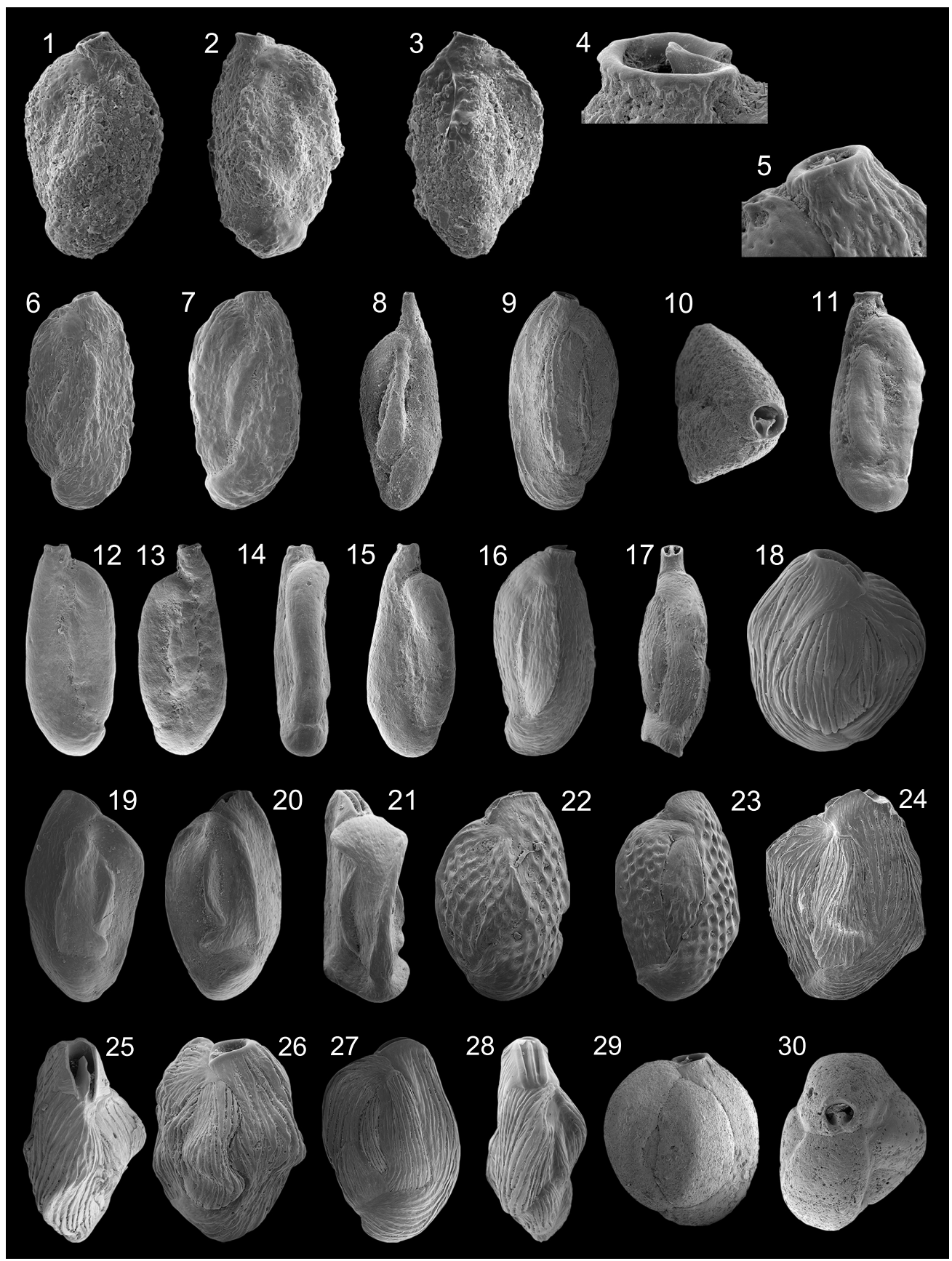

FIGURE 14. 1 Siphonaperta sp. 2, 1050x, side view; 2 Siphonaperta sp. 2, 982x, side view; 3 Siphonaperta sp. 2, 818x, side view; 4 Siphonaperta sp. 2, 3040x, enlargement of aperture; 5 Cycloforina contorta (d'Orbigny), 1680x, enlargement of aperture; 6 C. contorta (d'Orbigny), 454x, four chamber side; 7 C. contorta (d'Orbigny), 969x, three chamber side; 8 Cycloforina? tenuicollis (Wiesner), 592x, four chamber side; 9 Cycloforina villafranca (Le Calvez and Le Calvez), 281x, four chamber side; $10 \mathrm{C}$. villafranca (Le Calvez and Le Calvez), 281x, apertural face; 11 Cycloforina sp. 1, 566x, four chamber side; 12 Cycloforina sp. 1, 603x, three chamber side; 13 Cycloforina sp. 1, 451x, four chamber side; 14 Cycloforina sp. 1, 451x, peripheral view; 15 Cycloforina sp. 1, 644x, three chamber side; 16 Cycloforina? sp. 2, 835x, four chamber side; 17 Cycloforina? sp. 2, 570x, peripheral view; 18 Lachlanella bicornis ((Walker and Jacob) emend. Haynes), 297x, four chamber side; 19 Lachlanella bradyana (Cushman), 360x, side view; 20 L. bradyana (Cushman), 525x, side view; 21 L. bradyana (Cushman), 283x, peripheral view; 22 Lachlanella carinata (d'Orbigny), 463x, side view; 23 L. carinata (d'Orbigny), 430x, side view; 24 Lachlanella undulata (d'Orbigny), 207x, side view; 25 L. undulata (d'Orbigny), 150x, apertural edge view; 26 L. undulata (d'Orbigny), 376x, side view; 27 Lachlanella sp. 1, 185x, side view; 28 Lachlanella sp. 1, 190x, apertural edge view; 29 Quinqueloculina agglutinata Cushman, 254x, four chamber side; 30 Q. agglutinata Cushman, 258x, apertural view. 
1958 Quinqueloculina contorta d'Orbigny; Le Calvez and Le Calvez, 171, pl. 12, figs. 140-142

1974 Cycloforina contorta (d'Orbigny); Luczkowska, p. 74 , pl. 11, figs. 2, 3

1988 Cycloforina contorta (d'Orbigny); Loeblich and Tappan, p. 91, pl. 342, figs. 4-9 [figs. 7-9: cop. d'Orbigny, 1846, figs. 4-6]

1991 Cycloforina contorta (d'Orbigny); Cimerman and Langer, p. 32, pl. 27, figs. 7-11

1993 Quinqueloculina contorta d'Orbigny; Sgarrella and Moncharmont Zei, p. 170, pl. 6, figs. 5,6

Remarks: The wall is porcelaneous and imperforate. The test is ovate to subrectangular in lateral view. The chamber arrangement is "quinqueloculine." The peripheral margins are acutely angled. The aperture, on a very short neck, is rounded, bordered by a rim and provided with a short, bifid tooth. The test surface is ornamented with costae and microstriae.

Cycloforina? tenuicollis (Wiesner, 1923) Figure 14.8

1923 Miliolina tenuicollis Wiesner: p. 48, pl. 6, fig. 66

1958 Quinqueloculina tenuicollis (Wiesner); Le Calvez and Le Calevez, p. 173, pl. 11, figs. 127, 128

1991 Cycloforina tenuicollis (Wiesner); Cimerman and Langer, p. 33, pl. 28, figs. 5-6

1993 Quinqueloculina tenuicollis (Wiesner); Sgarrella and Moncharmont Zei, p. 175, pl. 6 , figs. 10, 11

2009 Cycloforina tenuicollis (Wiesner); Avsar et al., p. 134, pl. 1, fig. 18

Remarks: The wall is porcelaneous and imperforate. The test is fusiform in lateral view. The chamber arrangement is "quinqueloculine." The peripheral margins are acutely angled. The aperture, on a long and thin neck, is rounded and provided with a tooth. The test surface is rough. The generic position is questionable due to this species has no ornamentation with striae or costae as defined for Cycloforina species in Loeblich and Tappan (1988) and due to its long neck.

Cycloforina villafranca (Le Calvez and Le Calvez, 1958)

Figure 14.9-10
1958 Quinqueloculina villafranca Le Calvez and Le Calvez: p. 180, pl. 4, figs. 22, 23

1991 Cycloforina villafranca (Le Calvez and Le Calvez); Cimerman and Langer, p. 33, pl. 28, figs. 7-9

1993 Quinqueloculina villafranca Le Calvez and Le Calvez; Sgarrella and Moncharmont Zei, p. 176, pl. 7, figs. 3, 4

2005 Cycloforina villafranca (Le Calvez and Le Calvez); Rasmussen, p. 62 , pl. 4 , fig. 3

Remarks: The wall is porcelaneous and imperforate. The test is elongate-ovate in lateral view. The chamber arrangement is "quinqueloculine," and five chambers are visible from the exterior. The aperture, on a very short neck, is rounded, bordered by a rim and provided with a short, bifid tooth. The test surface is ornamented with costae, in particularly on the chamber's periphery.

Cycloforina sp. 1

Figure 14.11-15

1993 cf. Cycloforina sp. A; Hottinger, Halicz and Reiss, p. 50, pl. 34, figs. 13-16

Remarks: The wall is porcelaneous. The test is elongate and laterally compressed. Chambers are slightly inflated and arranged in "quinqueloculine form." Five chambers are visible from the exterior. The periphery is rounded. The aperture is subrounded, on a neck, bordered by a rim and provided with a short, bifid tooth. The test surface is slightly rugose and ornamented with anastoming microstriae. Our specimens have many similarities to the material shown in Hottinger, Halicz and Reiss (1993), but the specimens illustrated there have longer necks and a more rugose test surface.

\section{Cycloforina? sp. 2}

Figure 14.16-17

Remarks: The wall is porcelaneous and imperforate. The test is elongate-ovate in lateral view. The chamber arrangement is "quinqueloculine." Four chambers are visible from one side and three chambers from the other side. The peripheral margins are acutely angled. The aperture is ovate at the end of the final chamber, bordered by a rim and provided with a relatively long and slender tooth with a short bifid termination. The test is ornamented with weak and minute longitudinal anastoming microstriae. The generic status of this species is not clear due to Cycloforina species are defined by Loeblich and Tappan (1988) as species having a circular aperture with a short simple or bifid tooth. 
Genus LACHLANELLA Vella, 1957

Lachlanella bicornis ((Walker and Jacob) emend.

Haynes, 1973)

Figure 14.18

1798 Serpula bicornis Walker and Jacob: p. 633, pl. 14, fig. 2

1884 Miliolina bicornis (Walker and Jacob); Brady, p. 171, pl. 6, fig. 9 (not figs. 11, 12)

1973 Quinqueloculina bicornis (Walker and Jacob) emend. Haynes: p. 67, pl. 7, fig. 18; text-fig. 16

1987 Quinqueloculina bicornis (Walker and Jacob); Alberola et al., p. 305, pl. 2, figs. 10, 14

1991 Lachlanella bicornis ((Walker and Jacob) emend. Haynes); Cimerman and Langer, p. 34 , pl. 29 , figs. $1-3$

1991 Adelosina bicornis ((Walker and Jacob) emend. Haynes); Jones, p. 22, pl. 6, fig. 9 [cop. Brady, 1884, fig. 9]

2006 Quinqueloculina bicornis Walker and Jacob; Avsar et al., p. 132, pl. 1, fig. 5

Remarks: The wall is porcelaneous and imperforate. The test is ovate in lateral view and subrectangular in apertural view. The chamber arrangement is "quinqueloculine." Five chambers are visible from the exterior. The aperture is elongate, with subparallel sides, bordered by a rim and provided with a long, slender tooth. The test surface is ornamented with thick longitudinal costae.

Lachlanella bradyana (Cushman, 1917) Figures 14.19-21

1884 Miliolina undosa Karrer, sp.; Brady, p. 176, pl. 6, figs. 6, 7

1917 Quinqueloculina bradyana Cushman: p. 52, pl. 18 , fig. 2

1929 Quinqueloculina bradyana Cushman; Cushman, p. 23, pl. 1, fig. 3

1958 Quinqueloculina bradyana Cushman; Le Calvez and Le Calvez, p. 172, pl. 11, figs. 129, 130

1994 Quinqueloculina bradyana Cushman; Jones, p. 22, pl. 6, figs. 6, 7 [cop. Brady 1884, figs. 6, 7]

1995 Quinqueloculina bradyana Cushman; Coppa and Di Tuoro, p. 166, pl. 1, fig. 12

Remarks: The wall is porcelaneous and imperforate. The test is elongate-ovate in lateral view and depressed in apertural view. The chamber arrange- ment is "quinqueloculine." Chamber peripheral margins are sinuously angled, and early chambers are prominent. The aperture is elongate, with subparallel sides, bordered by a rim and provided with a long, slender tooth. The test surface is ornamented with grooves.

Lachlanella carinata (d'Orbigny, 1839a) Figure 14.22-23

1839a Triloculina carinata d'Orbigny: p. 179, pl. 10, figs. 15,17

1929 Triloculina carinata d'Orbigny; Cushman, p. 65 , pl. 17 , fig. 5

1958 Quinqueloculina reticulata (d'Orbigny) var. carinata d'Orbigny; Le Calvez and Le Calvez, p. 183, pl. 5, figs. 34, 35, 43

Remarks: The wall is porcelaneous and imperforate. The test is subelliptical in lateral view and lenticular in apertural view. The chamber arrangement is "quinqueloculine." The periphery of the later chambers is angled. The peripheral margin is carinate. The aperture is elongate, with subparallel sides, bordered by a rim and provided with a long, slender tooth. The test surface is ornamented in a reticulate pattern.

Lachlanella undulata (d'Orbigny, 1826)

Figure 14.24-26

1826 Quinqueloculina undulata d'Orbigny: $p$. 302, no. 27

1958 Quinqueloculina undulata d'Orbigny; Le Calvez and Le Calvez, p. 179, pl. 13, figs. 146-148

1991 Lachlanella undulata (d'Orbigny); Cimerman and Langer, p. 34, pl. 30, figs. 3-6

1993 Quinqueloculina undulata d'Orbigny; Sgarrella and Moncharmont Zei, p. 175, pl. 7, fig. 6

2005 Lachlanella undulata (d'Orbigny); Rasmussen, p. 62 , pl. 4 , fig. 4

Remarks: The wall is porcelaneous and imperforate. The test is ovate in lateral view. The chamber arrangement is "quinqueloculine." Five chambers are visible from the exterior. The aperture is elongate, with subparallel sides, bordered by a rim and provided with a long, slender tooth. The test surface is densely ornamented with longitudinal costae. It differs from Lachlanella bicornis by the more irregularly shape of the chambers and the slightly thinner costae. 


\section{Lachlanella sp. 1}

Figure 14.27-28

Remarks: The wall is porcelaneous and imperforate. The test is ovate in lateral view. The chamber arrangement is "quinqueloculine." Five chambers are visible from the exterior. The aperture is elongate, with subparallel sides, bordered by a rim and provided with a long, slender tooth. The test surface is densely ornamented with longitudinal costae. It differs from Lachlanella bicornis by the more angled chambers periphery and the slightly thinner costae, and from Lachlanella undulata by the more regular chamber shape.

Genus QUINQUELOCULINA d'Orbigny, 1826

Quinqueloculina agglutinata Cushman, 1917

Figure 14.29-30

1917 Quinqueloculina agglutinata Cushman: p. 43 , pl. 9 , fig. 2

Remarks: The wall is porcelaneous and imperforate. The test is ovate in lateral view and subrounded in apertural view. The chamber arrangement is "quinqueloculine," with four chambers on one and three on the other side. The periphery is broadly rounded. The aperture is ovate and provided with a bifid tooth. The test surface is rough. The outer wall is agglutinated with lighter and darker sand grains.

Quinqueloculina auberiana d'Orbigny, 1839a Figure 15.1-2

1839a Quinqueloculina auberiana d'Orbigny: $p$. 193, pl. 12, figs. 1-3

1917 Quinqueloculina auberiana d'Orbigny; Cushman, p. 46, pl. 12, fig. 1

1991 Quinqueloculina auberiana d'Orbigny;

Cimerman and Langer, p. 36, pl. 32, figs. 8, 9

Remarks: The wall is porcelaneous and imperforate. The test is ovate in lateral view and nearly as broad as long. It is nearly triangular in apertural view. The chamber arrangement is "quinqueloculine." The aperture is ovate and provided with a short bifid tooth. The test is ornamented with minute striae. The test surface is rough.

Quinqueloculina berthelotiana d'Orbigny, 1839b

Figure 15.3-6

1839b Quinqueloculina berthelotiana d'Orbigny: p. 142 , pl. 3 , figs. $25-27$
1958 Quinqueloculina berthelotiana d'Orbigny; Le Calvez and Le Calvez, p. 173, pl. 10, figs. 115-117

1987 Quinqueloculina berthelotiana d'Orbigny; Alberola et al., p. 305, pl. 3, fig. 2

1991 Quinqueloculina berthelotiana d'Orbigny; Cimerman and Langer, p. 36, pl. 32, figs. 5-7

1993 Quinqueloculina berthelotiana d'Orbigny; Sgarrella and Moncharmont Zei, p. 170, pl. 6 , figs. 1,2

2005 Quinqueloculina berthelotiana d'Orbigny; Rasmussen, p. 62, pl. 4, fig. 6

2006 Quinqueloculina berthelotiana d'Orbigny; Avsar et al., p. 132, pl. 1, fig. 6

Remarks: The wall is porcelaneous and imperforate. The test is ovate in lateral view and nearly triangular in apertural view. The chamber arrangement is "quinqueloculine." Four chambers are visible from one side and three from the other side. The peripheral chamber margins are acutely angled. The rounded aperture, on a short neck, is bordered by rim and provided with a short, bifid tooth. The test is ornamented with longitudinal microstriae and has a rough surface.

Quinqueloculina bosciana d'Orbigny, 1839a Figure 15.7-9

1839a Quinqueloculina bosciana d'Orbigny: $p$. 191, pl. 11, figs. 22-24

1991 Quinqueloculina bosciana d'Orbigny; Cimerman and Langer, p. 36, pl. 33, figs. 5-7

1993 Quinqueloculina bosciana d'Orbigny; Sgarrella and Moncharmont Zei, p. 170, pl. 6 , figs. 8,9

Remarks: The wall is porcelaneous, imperforate and hyaline. The test is very elongate in lateral view and suboval in apertural view. The chamber arrangement is "quinqueloculine." The earlier chambers in the middle part are slightly oblique in relation to the later chambers. The aperture is rounded, bordered by rim and provided with a primitive tooth. The test surface is smooth. Our specimens are more elongate than that shown by the other authors.

\section{Quinqueloculina disparilis d'Orbigny, 1826} Figure 15.10-12

Quinqueloculina disparilis d'Orbigny: $\mathrm{p}$. 302, no. 21 


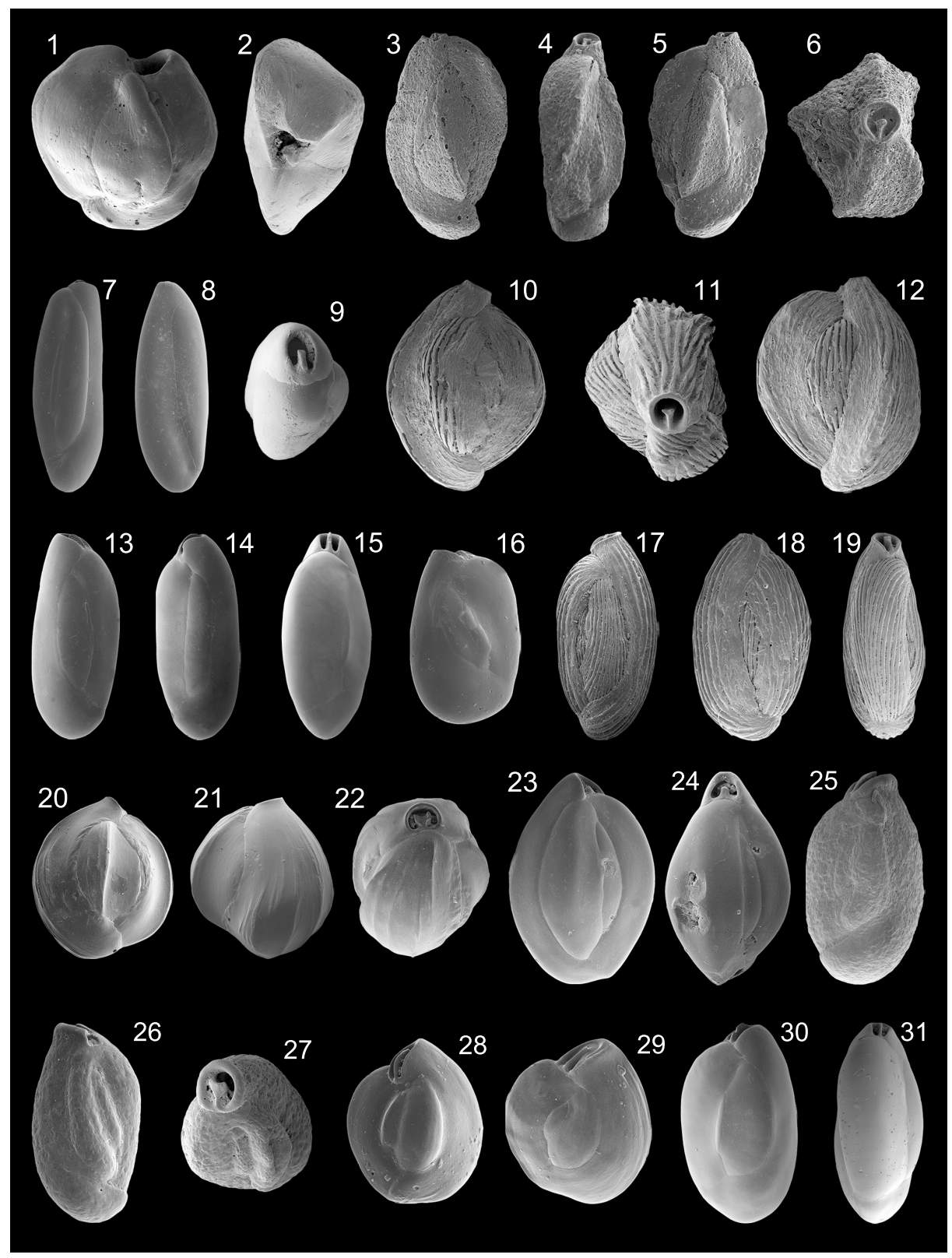

FIGURE 15. 1 Quinqueloculina auberiana d'Orbigny, 260x, side view; 2 Q. auberiana d'Orbigny, 217x, apertural edge view; 3 Quinqueloculina berthelotiana d'Orbigny, 489x, four chamber side; 4 Q. berthelotiana d'Orbigny, 276x, peripheral view; 5 Q. berthelotiana d'Orbigny, 271x, four chamber side; 6 Q. berthelotiana d'Orbigny, 309x, apertural edge view; 7 Quinqueloculina bosciana d'Orbigny, 267x, four chamber side; 8 Q. bosciana d'Orbigny, 529x, three chamber side; 9 Q. bosciana d'Orbigny, 637x, apertural view; 10 Quinqueloculina disparilis d'Orbigny, 259x, four chamber side; 11 Q. disparilis d'Orbigny, 163x, apertural view; 12 Q. disparilis d'Orbigny, 313x, three chamber side; 13 Quinqueloculina laevigata d'Orbigny, 361x, four chamber side; 14 Q. laevigata d'Orbigny, 390x, three chamber side; 15 Q. laevigata d'Orbigny, 156x, peripheral view; 16 Quinqueloculina lata Terquem, 911x, side view; 17 Quinqueloculina limbata d'Orbigny, 162x, four chamber side; 18 Q. limbata d'Orbigny, 228x, three chamber side; 19 Q. limbata d'Orbigny, 129x, peripheral view; 20 Quinqueloculina neapolitana Sgarrella and Moncharmont Zei, 322x, four chamber side; 21 Q. neapolitana Sgarrella and Moncharmont Zei, 323x, three chamber side; 22 Q. neapolitana Sgarrella and Moncharmont Zei, 370x, apertural edge view; 23 Quinqueloculina padana Perconig, 880x, four chamber side; 24 Q. padana Perconig, 628x, peripheral view; 25 Quinqueloculina parvula Schlumberger, 609x, four chamber side; 26 Q. parvula Schlumberger, 939x, four chamber side; 27 Q. parvula Schlumberger, 719x, apertural edge view; 28 Quinqueloculina pseudobuchiana Luczowksa, 763x, four chamber side; 29 Q. pseudobuchiana Luczowksa, 892x, four chamber side; 30 Quinqueloculina seminula (Linné), 257x, side view; 31 Q. seminula (Linné), 113x, peripheral view. 
1929

Quinqueloculina disparilis d'Orbigny; Cushman, p. 32, pl. 5, fig. 4

1958 Quinqueloculina disparilis d'Orbigny; Le Calvez and Le Calvez, p. 180, pl. 4, figs. 26, 27

1991 Quinqueloculina disparilis d'Orbigny; Cimerman and Langer, p. 36, pl. 33, figs. 1-4

1993 Quinqueloculina disparilis d'Orbigny; Sgarrella and Moncharmont Zei, p. 170, pl. 8, fig. 2

1995 Quinqueloculina disparilis d'Orbigny; Coppa and Di Tuoro, p. 168, pl. 2, fig. 2

Remarks: The wall is porcelaneous and imperforate. The test is subrounded in lateral view, with a width to length ratio of nearly one. The chamber arrangement is "quinqueloculine." Four chambers are visible from one side and three from the other side. The aperture is rounded, bordered by rim and provided with a relatively long, bifid tooth. The test surface is ornamented with thick, longitudinal costae on the chamber periphery and smaller costae on the lateral chamber walls.

Quinqueloculina laevigata d'Orbigny, 1826

Figure 15.13-15

1826 Quinqueloculina laevigata d'Orbigny: p. 301, no. 6

1929 Quinqueloculina laevigata d'Orbigny; Cushman, p. 30, pl. 4, fig. 3

1958 Quinqueloculina laevigata d'Orbigny; Le Calvez and Le Calvez, p. 184, pl. 10, figs. 112-114

1965 Quinqueloculina laevigata d'Orbigny; Phleger, p. 53, pl. 1, fig. 23

1991 Quinqueloculina laevigata d'Orbigny; Cimerman and Langer, p. 37, pl. 33, figs. 8-11

Remarks: The wall is porcelaneous and imperforate. The test is elongate in lateral view and subovate in peripheral view. The chamber arrangement is "quinqueloculine." Three chambers are visible from the exterior. The aperture is ovate and provided with a long, slender tooth. The test surface is smooth.

Quinqueloculina lata Terquem, 1876

Figure 15.16

1876 Quinqueloculina lata Terquem: p. 82, pl. 11, fig. 8a-c (fide Ellis and Messina, 1940ff)
1958 Quinqueloculina lata Terquem; Le Calvez, p. 158 , pl. 2, figs. $26-28$

1993 Quinqueloculina lata Terquem; Sgarrella and Moncharmont Zei, p. 172, pl. 5, fig. 15

2003 Quinqueloculina lata Terquem; Murray, $p$. 17, fig. 4, no. 9, 10

Remarks: The wall is porcelaneous and imperforate. The test of these small specimens is subrectangular in lateral view. The chamber arrangement is "quinqueloculine." Four chambers are visible from one side and three from the other side. The peripheral margin is rounded. The aperture is ovate and provided with a short, broad and bifid tooth. The test surface is smooth.

\section{Quinqueloculina limbata d'Orbigny, 1826 \\ Figure 15.17-19}

1826 Quinqueloculina limbata d'Orbigny: p. 302, no. 20

1915 Miliolina limbata (d'Orbigny); Heron-Allen and Earland, p. 577, pl. 44, figs. 5-8

1991 Quinqueloculina limbata d'Orbigny; Cimerman and Langer, p. 37, pl. 34, figs. $1-5$

Remarks: The wall is porcelaneous and imperforate. The test is subelliptical in lateral view. The chamber arrangement is "quinqueloculine." Four chambers are visible from one side and three from the other side. The peripheral margin is rounded. The aperture is rounded, on a short neck and provided with a relatively slender, bifid tooth. The test surface is ornamented with longitudinal costae.

\section{Quinqueloculina neapolitana Sgarrella and Moncharmont Zei, 1993 \\ Figure 15.20-22}

1993 Quinqueloculina neapolitana Sgarrella and Moncharmont Zei: p. 173, pl. 5, figs. 10-12

Remarks: The wall is porcelaneous and imperforate. The test is subrounded in lateral view, with a width to length ratio of nearly one and ovate in apertural view. The chamber arrangement is "quinqueloculine." Chambers are inflated. Three to four chambers are visible from one side and two to three from the other side. The peripheral margin is broadly rounded. The aperture is ovate, bordered by a rim and provided with a short, bifid tooth. The test surface is partly ornamented with longitudinal striae with different distances from each other.

Quinqueloculina padana Perconig, 1954

Figure 15.23-24 
1954 Quinqueloculina padana Perconig: pp. 9597, text-figs. 1-4

1987 Quinqueloculina badenensis d'Orbigny; Jorissen, p. 43, pl. 4, fig. 10

1993 Quinqueloculina padana Perconig; Sgarrella and Moncharmont Zei, p. 172, pl. 7, fig. 1

2005 Quinqueloculina padana Perconig; Rasmussen, p. 63, pl. 4, figs. 8,9

2009 Quinqueloculina padana Perconig; Frezza and Carboni, p. 55, pl. 1, fig. 9

Remarks: The wall is porcelaneous and imperforate. The test is subelliptical in lateral view. The chamber arrangement is "quinqueloculine." Four chambers are visible from one side and three from the other side. The aperture is subtriangular and provided with a short flap-like tooth. The test surface is smooth.

Quinqueloculina parvula Schlumberger, 1894 Figure 15.25-27

1894 Quinqueloculina parvula Schlumberger: $p$. 255, text-fig. 1, pl. 3, figs. 8, 9

1958 Quinqueloculina parvula Schlumberger; Le Calvez and Le Calvez, p. 184, pl. 11, figs. 131-133

1991 Quinqueloculina parvula Schlumberger; Cimerman and Langer, p. 37, pl. 34, figs. 6-8

1993 Quinqueloculina parvula Schlumberger; Sgarrella and Moncharmont Zei, p. 174, pl. 5, fig. 16

Remarks: The wall is porcelaneous and imperforate. The test is ovate in lateral view. The chamber arrangement is "quinqueloculine." Four chambers are visible from one side and three from the other side. The chamber margins are rounded. The aperture is ovate, bordered by a thickened rim and provided with a short, bifid tooth. The test is ornamented with minute anastoming microstriae, and the test surface is rough.

Quinqueloculina pseudobuchiana Luczkowska, 1974

Figure 15.28-29

1974 Quinqueloculina pseudobuchiana Luczkowska: p. 58, pl. 4, fig. 5; pl. 5, figs. 1, 2

1991 Quinqueloculina pseudobuchiana Luczkowska; Cimerman and Langer, p. 38, pl. 35 , figs. $1-4$
Remarks: The wall is porcelaneous and imperforate. The test is subrounded in lateral view. The chamber arrangement is "quinqueloculine." Four chambers are visible from one side and three from the other side. The aperture is elongate and provided with a long, bifid tooth. The test surface is smooth, with a few striae on the peripheral margin of the later chambers.

Quinqueloculina seminula (Linné, 1758)

Figures 15.30-31

1758 Serpula seminula Linné: p. 786

1917 Quinqueloculina seminulum (Linné); Cushman, p. 44, pl. 11, fig. 2

1929 Quinqueloculina seminulum (Linné); Cushman, p. 24, pl. 2, figs. 1, 2

1960 Quinqueloculina seminulum (Linné); Hofker, p. 241, pl. B, fig. 41

1985 Quinqueloculina seminula (Linné); Hermelin and Scott, p. 216, pl. 2, fig. 3

1988 Quinqueloculina seminula (Linné); Loeblich and Tappan, p. 92, pl. 344, figs. 8-13

1991 Quinqueloculina seminula (Linné); Cimerman and Langer, p. 38, pl. 34, figs. 9-12

1992 Quinqueloculina seminula (Linné); Schiebel, p. 64, pl. 5, fig. 3

1992 Quinqueloculina seminula (Linné); Wollenburg, p. 40, pl. 10, fig. 8

1994 Quinqueloculina seminulum (Linné); Jones, p. 21, pl. 5, fig. 6

2006 Quinqueloculina seminula (Linné); Avsar et al., p. 132, pl. 1, fig. 7

2009 Quinqueloculina seminula (Linné); Frezza and Carboni, p. 55, pl. 1, figs. 10, 11

2009 Quinqueloculina seminula (Linné); Milker et al., p. 216, pl. 2, figs. 3, 4

Remarks: The wall is porcelaneous and imperforate. The test is ovate to subrounded in lateral view and triangular in apertural view. The chamber arrangement is "quinqueloculine." Four chambers are visible from one side and three from the other side. The aperture is subrounded, bordered by a rim and provided with a relatively long, simple tooth. The test surface is smooth.

Quinqueloculina stelligera Schlumberger, 1893 Figure 16.1-4

1893 Quinqueloculina stelligera Schlumberger: p. 68 , pl. 2 , figs. 58,59 ; text-fig. 17 


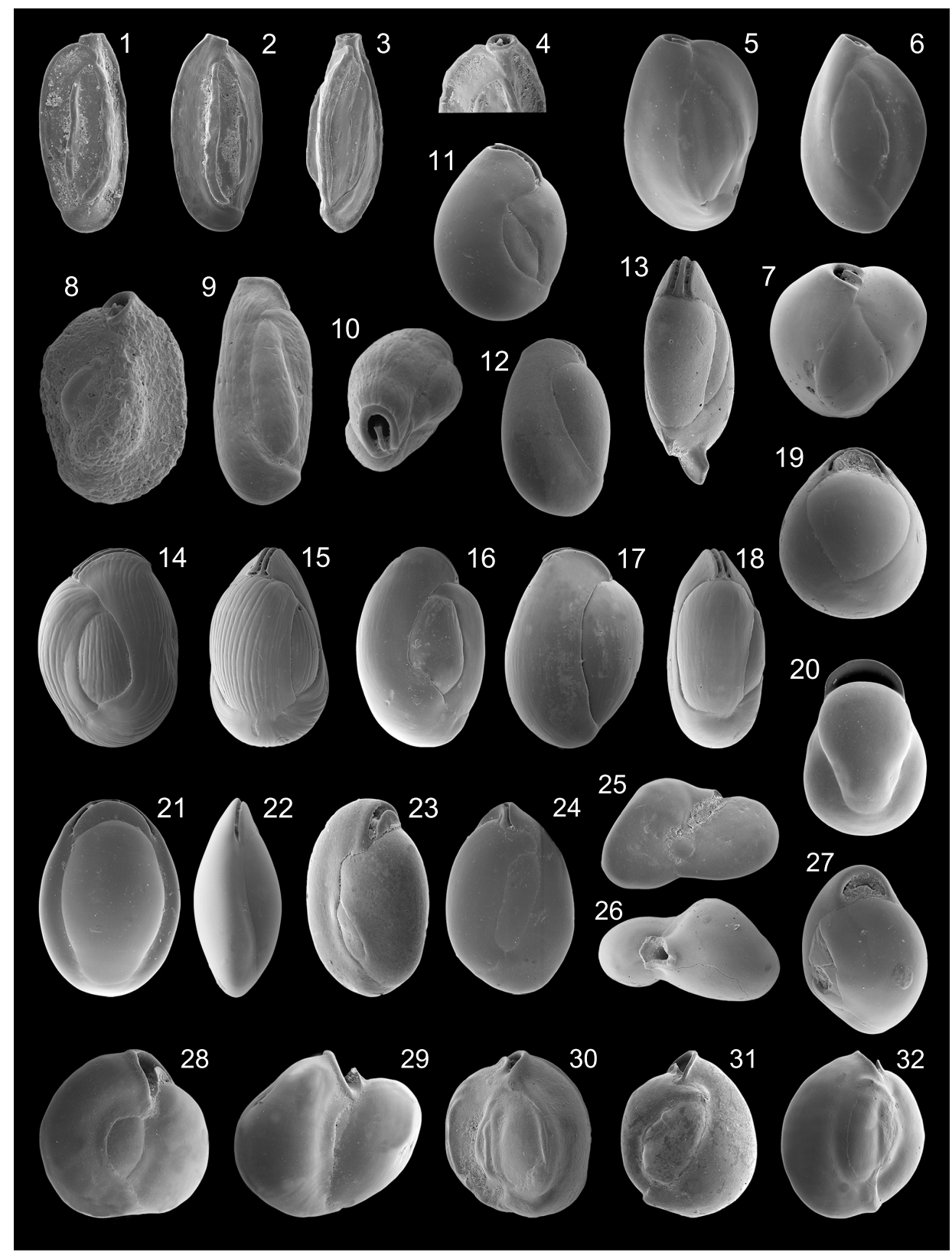

FIGURE 16. 1 Quinqueloculina stelligera Schlumberger, 779x, four chamber side; 2 Q. stelligera Schlumberger, 717x, four chamber side; 3 Q. stelligera Schlumberger, 777x, peripheral view; 4 Q. stelligera Schlumberger, 576x, enlargement of aperture; 5 Quinqueloculina viennensis Le Calvez and Le Calvez, 489x, four chamber side; 6 Q. viennensis Le Calvez and Le Calvez, 535x, four chamber side; 7 Q. viennensis Le Calvez and Le Calvez, 246x, four chamber side; 8 Quinqueloculina sp. 1, 938x, four chamber side; 9 Affinetrina gualtieriana (d'Orbigny), 560x, three chamber side; 10 A. gualtieriana (d'Orbigny), 789x, apertural edge view; 11 Affinetrina ucrainica (Serova), 1070x, three chamber side; 12 A. ucrainica (Serova), 1100x, two chamber side; 13 A. ucrainica (Serova), 920x, peripheral view; 14 Affinetrina sp. 1, 398x, three chamber side; 15 Affinetrina sp. 1, 291x, peripheral view; 16 Affinetrina sp. 2, 386x, three chamber side; 17 Affinetrina sp. 2, 370x, two chamber side; 18 Affinetrina sp. 2, 272x, peripheral view; 19 Biloculinella globula (Bornemann), 497x, lateral view; 20 Biloculinella inflata (Wright), 1100x, lateral view; 21 Biloculinella labiata (Schlumberger), 331x, lateral view; 22 B. labiata (Schlumberger), 347x, peripheral view; 23 Miliolinella elongata Kruit, 1640x, oblique side view; 24 M. elongata Kruit, 552x, side view; 25 Miliolinella cf. hybrida (Terquem), 555x, side view; 26 M. cf. hybrida (Terquem), 452x, apertural edge view; 27 Miliolinella irregularis (d'Orbigny), 770x, oblique side view; 28 Miliolinella labiosa (d'Orbigny), 534x, side view; 29 M. labiosa (d'Orbigny), 365x, side view; 30 Miliolinella semicostata (Wiesner), 576x, side view; 31 Miliolinella subrotunda (Montagu), 809x, side view; 32 M. subrotunda (Montagu), 996x, side view. 
1929 Quinqueloculina stelligera Schlumberger; Cushman, p. 28, pl. 3, figs. 3, 4

1958 Quinqueloculina stelligera Schlumberger; Le Calvez and Le Calvez, p. 174, pl. 11, figs. 125,126

1991 Quinqueloculina stelligera Schlumberger; Cimerman and Langer, p. 38, pl. 34, figs. 13-15

1993 Quinqueloculina stelligera Schlumberger; Sgarrella and Moncharmont Zei, p. 175, pl. 6 , figs. 13,14

2004 Quinqueloculina stelligera Schlumberger; Fiorini, p. 50, pl. 1, fig. 10

Remarks: The wall is porcelaneous and imperforate. The test is elongate-ovate in lateral view and star-like in apertural view. The chamber arrangement is "quinqueloculine." Four to five chambers are visible from the exterior. The peripheral chamber margins are acutely angled and thickened. The aperture is rounded and provided with a short, bifid tooth. The test surface is smooth.

Quinqueloculina viennensis Le Calvez and Le Calvez, 1958

Figure 16.5-7

1958 Quinqueloculina viennensis Le Calvez and Le Calvez: p. 187, pl. 5, figs. 42, 44, 45

1993 Quinqueloculina viennensis Le Calvez and Le Calvez; Sgarrella and Moncharmont Zei, p. 176, pl. 7, fig. 8

2005 Quinqueloculina viennensis Le Calvez and Le Calvez; Rasmussen, p. 64, pl. 4, fig. 13

Remarks: The wall is porcelaneous and imperforate. The test is subcylindrical in lateral view and triangular in apertural view. The chamber arrangement is "quinqueloculine." Four chambers are visible from one side and three from the other side. The chamber margins are angled. The aperture is subrounded and provided with a relatively long, simple tooth. The test surface is smooth.

\section{Quinqueloculina sp. 1}

Figure 16.8

Remarks: The wall is porcelaneous and imperforate. The test of these small specimens is ovate in lateral view. The chamber arrangement is "quinqueloculine." Five chambers are visible from the exterior. The peripheral margin is rounded. The aperture is ovate, bordered by a rim and provided with a short, bifid tooth. The test is ornamented with minute anastoming microstriae, except for the earlier chambers, leading to a rough test surface.
Subfamily MILIOLINELLINAE Vella, 1957

Genus AFFINETRINA Luczkowska, 1972

Affinetrina gualtieriana (d'Orbigny, 1839a)

Figure 16.9-10

1839a Triloculina gualtieriana d'Orbigny: p. 170, pl. 9, figs. 5-7

1974 Affinetrina gualteriana (d'Orbigny); Luczkowska, p. 109, pl. 26, figs. 1, 2; text-fig. 38.3

Remarks: The wall is porcelaneous and imperforate. The test is elongate in lateral view and ovate in apertural view. Chambers are arranged in a triloculine pattern, with three chambers visible from the exterior. The ovate aperture is bordered by a thickened rim and provided with a relatively long, bifid tooth. The test surface is ornamented with short longitudinal and incised lines.

Affinetrina ucrainica

(Serova, in Bogdanovich 1952)

Figure 16.11-13

1952 Miliolina ucrainica Serova: type reference Bogdanovich, 1952, p. 104, pl. 8, fig. 2 (fide Luczkowska, 1974)

1974 Affinetrina ucrainica (Serova); Luczkowska, p. 111, pl. 16, fig. 3

2007 Affinetrina ucrainica (Serova); Schuetz et al., p. 453 , pl. 2 , fig. 2

Remarks: The wall is porcelaneous and imperforate. The test is ovate in lateral view and depressed in section. Three chambers are visible from the exterior, with two large outer and one small middle chamber. Sutures are slightly depressed. The peripheral margin is rounded. A keel-like feature may be present at the base of the final chamber. The aperture is slit-like, with nearly two parallel sides. The tooth is long, slender and simple, becoming slightly smaller to the end. It nearly fills the entire aperture. The test surface is very smooth.

\section{Affinetrina sp. 1}

Figure 16.14-15

Remarks: The wall is porcelaneous and imperforate. The test is ovate in outline and subovate in section. The chamber arrangement is triloculine, and three chambers are visible from the exterior. The peripheral margin is rounded. The aperture is a long slit with a long, slender tooth, almost completely filling the slit-like opening. The test surface is ornamented with longitudinal striae. 


\section{Affinetrina sp. 2}

Figure 16.16-18

Remarks: The wall is porcelanous and imperforate. The test is ovate in outline and subovate in section. The chamber arrangement is triloculine, and three chambers are visible from the exterior. The peripheral margin is rounded. The aperture is a long slit with a long, slender tooth, almost completely filling the slit-like opening. The test surface is smooth and ornamented with some microstriae on the later chambers.

Genus BILOCULINELLA Wiesner, 1931

Biloculinella globula (Bornemann, 1855)

Figure 16.19

1855 Biloculina globulus Bornemann: p. 349, pl. 19, fig. 3

1917 Biloculina globulus Bornemann; Cushman, p. 78 , pl. 31, fig. 2

1932 Pyrgo globula (Bornemann); Cushman, p. 65 , pl. 15 , figs. $6-8$

1958 Biloculinella globula (Bornemann); Le Calvez and Le Calvez, p. 202, pl. 7, fig. 76

1991 Biloculinella globula (Bornemann); Cimerman and Langer, p. 40, pl. 36, figs. 1, 2

2002 Biloculinella globula (Bornemann); Kaminski et al., p. 172, pl. 2, fig. 1

2005 Biloculinella globula (Bornemann); Rasmussen, p. 64, pl. 4, fig. 14

Remarks: The wall is porcelaneous and imperforate. The test is globulose. The adult chamber arrangement is "biloculine" with two chambers visible from the exterior. The periphery is broadly rounded. The terminal aperture is a slit-like opening due to it is nearly closed by a broad flap, and it is bordered by a thin rim. The test surface is smooth.

\section{Biloculinella inflata (Wright, 1902)}

Figure 16.20

1902 Biloculina inflata Wright: p. 183, pl. 13, figs. 1-4

1993 Biloculinella inflata (Wright); Sgarrella and Moncharmont Zei, p. 188, pl. 10, fig. 12

Remarks: The wall is porcelaneous and imperforate. The test is ovate in lateral view. The adult chamber arrangement is "biloculine," and two inflated chambers are visible from the exterior. The periphery is broadly rounded. The terminal aperture is a slit-like opening due to it is nearly closed by a broad flap, and it is bordered by a thin rim. The test surface is smooth.

\section{Biloculinella labiata (Schlumberger, 1891) Figure 16.21-22}

1891 Biloculina labiata Schlumberger: p. 556, pl. 9, figs. 60-62, text-figs. 13,14

1958 Biloculinella labiata (Schlumberger); Parker, p. 255, pl. 1, figs. 10, 11

1974 Biloculinella labiata (Schlumberger); Luczkowska, p. 113, pl. 21, figs. 8, 9

1988 Biloculinella labiata (Schlumberger); Loeblich and Tappan, p. 93, pl. 348, figs. 1-4

1991 Biloculinella labiata (Schlumberger); Cimerman and Langer, p. 40, pl. 36, fig. 12

2009 Biloculinella labiata (Schlumberger); Avsar et al., p. 134, pl. 1, fig. 20

Remarks: The wall is porcelaneous and imperforate. The test is ovate in lateral view and subelliptical in peripheral view. The adult chamber arrangement is "biloculine," and two chambers are visible from the exterior. Chambers are inflated with rounded margins and an angled periphery. The terminal aperture is a slit-like opening due to it is nearly closed by a broad, crescentic flap. The test surface is smooth.

\section{Genus MILIOLINELLA Wiesner, 1931 Miliolinella elongata Kruit, 1955 Figure 16.23-24}

1955 Miliolinella circularis (Bornemann) var. elongata Kruit: p. 110, pl. 1, fig. 15

1991 Miliolinella elongata Kruit; Cimerman and Langer, p. 41, pl. 37, fig. 8

1993 Miliolinella circularis elongata Kruit; Sgarrella and Moncharmont Zei, p. 187, pl. 10, fig. 5

2009 Miliolinella elongata Kruit; Avsar et al., p. 134, pl. 1, fig. 21

Remarks: The wall is porcelaneous and imperforate. The test is elongate-ovate in lateral view and subelliptical in peripheral view. The early stage is "quinqueloculine," and later chambers are added planispirally. Three to four chambers are visible from the exterior. The periphery is subrounded. The terminal aperture is a slit-like opening, bordered by a rim, and provided with a low and crescentic flap. The test surface is smooth.

\section{Miliolinella cf. hybrida (Terquem, 1878)}

Figure 16.25-26 
1878 cf. Quinqueloculina hybrida Terquem: p. 79 , pl. 9 , fig. 23

1993 Miliolinella cf. hybrida (Terquem); Hottinger, Halicz and Reiss, p. 52, pl. 39, figs. 1-6

Remarks: The wall is porcelaneous. The test is ovate to subcircular in section and somewhat irregular. Chambers are strongly inflated and often distorted. Sutures are distinct and depressed. The aperture is terminal, arch-shaped, triangular, rounded or irregular. The test surface is smooth. Our specimens have no thickened rim, bordering the aperture and no basal flap (probably broken?) as described and illustrated by Hottinger, Halicz and Reiss (1993). An appendix-like feature as illustrated in Terquem (1878) has been seldom observed.

Miliolinella irregularis (d'Orbigny, 1839c)

Figure 16.27

1839c Biloculina irregularis d'Orbigny: p. 67, pl. 8, figs. 20, 21

1884 Biloculina irregularis d'Orbigny; Brady, p.140, pl. 1, figs. 17, 18

1929 Nummoloculina irregularis (d'Orbigny); Cushman, p. 46, PI. 10, figs. 2, 3 [cop. Brady 1884, figs. 17, 18]

1991 Miliolinella irregularis (d'Orbigny); Rasmussen, p. 363, fig. 6 , no. 3

1992 Nummoloculina irregularis (d'Orbigny); Wollenburg, p. 42, pl. 11, figs. 7, 8

1994 Pyrgoella irregularis (d'Orbigny); Jones, $p$. 18 , pl. 1, figs. 17, 18 [cop. Brady 1884, figs. 17, 18]

2008 Miliolinella irregularis (d'Orbigny); AbuZied et al., p. 51, pl. 1, figs. 12, 13

Remarks: The wall is porcelaneous. The test is ovate in lateral view with a broadly rounded periphery. The early stage is "quinqueloculine" and later planispiral. Chambers are slightly inflated. Sutures are depressed. The aperture is a terminal arch, provided with a low, arched flap. The test surface is smooth.

Miliolinella labiosa (d'Orbigny, 1839a)

Figure 16.28-29

1839a Triloculina labiosa d'Orbigny: p. 178, pl. 10, figs. $12-14$

1922c Triloculina labiosa d'Orbigny; Cushman, p. 77 , pl. 12, fig. 1
1958 Triloculina labiosa d'Orbigny; Le Calvez and Le Calvez, p. 196, pl. 14, figs. 168, 169

1960 Miliolinella labiosa (d'Orbigny); Hofker, p. 243, pl. B, fig. 54

1991 Miliolinella labiosa (d'Orbigny); Cimerman and Langer, p. 41, pl. 38, figs. 1-3

Remarks: The wall is porcelaneous and imperforate. The test is ovate to subcircular in lateral view. The length to width ratio is lower than one. The early stage is "quinqueloculine," and later chambers are added planispirally. Three inflated chambers are visible from the exterior. The periphery is rounded. The terminal aperture is bordered by a rim and provided with a low and arched flap. The test surface is smooth.

Miliolinella semicostata (Wiesner, 1923)

Figure 16.30

1923 Miliolina semicostata Wiesner: p. 72, pl. 14, figs. 177, 178

1991 Miliolinella semicostata (Wiesner); Cimerman and Langer, p. 42, pl. 38, figs. 10-15

1993 Miliolinella semicostata (Wiesner); Sgarrella and Moncharmont Zei, p. 187, pl. 10, fig. 7

2009 Miliolinella semicostata (Wiesner); Milker et al., p. 215, pl. 1, fig. 17

Remarks: The wall is porcelaneous and imperforate. The test is subcircular in lateral view and subtriangular to ovate in apertural view. The early stage is "quinqueloculine," and later chambers are added planispirally. Five chambers are visible from the exterior. The terminal aperture is bordered by a rim and provided with a low and arched flap. The chamber's periphery is ornamented with thick costae.

Miliolinella subrotunda (Montagu, 1803)

Figure 16.31-32

1803 Vermiculum subrotundum Montagu: p. 521

1929 Quinqueloculina? subrotunda (Montagu); Cushman, p. 25, pl. 2, fig. 4

1988 Miliolinella subrotunda (Montagu); Loeblich and Tappan, p. 93, pl. 350, figs. 1-12

1991 Miliolinella subrotunda (Montagu); Cimerman and Langer, p. 42, pl. 38, figs. 4-9

1992 Miliolinella subrotunda (Montagu); Schiebel, p. 28, pl. 5, fig. 1 
1994 Miliolinella subrotunda (Montagu); Jones, p. 20 , pl. 4 , fig. 3

2003 Miliolinella subrotunda (Monatgu); Murray, p. 15 , fig. 4 , no. 6

2005 Miliolinella subrotunda (Montagu); Debenay et al., p. 334, pl. 2, fig. 8

2005 Miliolinella subrotunda (Montagu); Rasmussen, p. 64 , pl. 4, fig. 15

2009 Miliolinella subrotunda (Montagu); Avsar et al., p. 134, pl. 1, figs. 22, 23

2009 Miliolinella subrotunda (Montagu); Milker et al., p. 215, pl. 1, fig. 18

Remarks: The wall is porcelaneous and imperforate. The test is subcircular in lateral view and ovate in apertural view. The early stage is "quinqueloculine," and later chambers are added planispirally. Three to four inflated chambers are visible from the exterior. The chambers periphery is rounded. The terminal aperture is bordered by a rim and provided with a low, arched flap. The test surface is smooth.

Miliolinella webbiana (d'Orbigny, 1839b)

Figure 17.1-2

1839b Triloculina webbiana d'Orbigny: p. 140, pl. 3 , figs. $13-15$

1958 Triloculina webbiana d'Orbigny; Le Calvez and Le Calvez, p. 195, pl. 15, figs. 176-178

1987 Miliolinella webbiana (d'Orbigny); Alberola et al., p. 306, pl. 2, fig. 12

1991 Miliolinella webbiana (d'Orbigny); Cimerman and Langer, p. 42, pl. 39, figs. 1-3

1993 Miliolinella webbiana (d'Orbigny); Sgarrella and Moncharmont Zei, p. 187, pl. 10, fig. 6

2009 Miliolinella webbiana (d'Orbigny); Milker et al., p. 215, pl. 1, fig. 19

Remarks: The wall is porcelaneous and imperforate. The test is subcircular in lateral view and ovate in apertural view. The early stage is "quinqueloculine," and later chambers are added planispirally. Five chambers are visible from the exterior. The chambers periphery is rounded. The terminal aperture is bordered by a rim and provided with a low and slightly arched flap. The test surface is densely ornamented with longitudinal costae.

\section{Miliolinella sp. 1}

1991 cf. Miliolinella sp. 2; Cimerman and Langer, p. 42, pl. 39, figs. 6, 7
Remarks: The wall is porcelaneous and imperforate. The test is ovate in lateral view. Early chambers are arranged in a "quinqueloculine" pattern and later nearly planispirally. Chambers are inflated and increasing in size as added. Three chambers are visible from the exterior. The peripheral margin is broadly rounded. The terminal aperture is provided with a low and arched flap. The test surface is smooth.

\section{Genus PSEUDOTRILOCULINA Cherif, 1970 \\ Pseudotriloculina sp. 1}

Figure 17.3-4

Remarks: The wall is porcelaneous and imperforate. The test is ovate in outline. Three chambers are visible from the exterior. The periphery is rounded. The terminal aperture is bordered by a rim and provided with a relatively long and protruding tooth with bifid termination. The test surface is smooth.

Genus PTYCHOMILIOLA Eimer and Fickert, 1899 Ptychomiliola separans? (Brady, 1881)

Figure 17.5-6

1881 cf. Miliolina separans Brady: p. 43

1884 cf. Ptychomiliola separans (Brady); Brady, p. 175 , pl. 7 , figs. $1-4$

1988 cf. Ptychomiliola separans (Brady); Loeblich and Tappan, p. 94, pl. 353, figs. 10, 11

1994 cf. Ptychomiliola separans (Brady); Jones, p. 23, pl. 7, figs. 1-4 [cop Brady, 1884, figs. 1-4]

Remarks: The wall is porcelaneous and imperforate. The specimens were mostly broken and have a somewhat curved test. The aperture is terminal and bordered with a rim. The tooth was not visible. The test surface is ornamented with numerous longitudinal costae. The identification may be incorrect.

Genus PYRGO Defrance, 1824

Pyrgo anomala (Schlumberger, 1891)

Figure 17.8-9

1891 Biloculina anomala Schlumberger: p. 569, pl. 11, figs. 84-85; pl. 12, fig. 101

1917 Biloculina anomala Schlumberger; Cushman, p. 79, pl. 32, fig. 1

1958 Pyrgo anomala (Schlumberger); Le Calvez and Le Calvez, p. 200, pl. 7, fig. 77

1958 Pyrgo anomala (Schlumberger); Parker, p. 255 , pl. 1 , figs. 22,23 


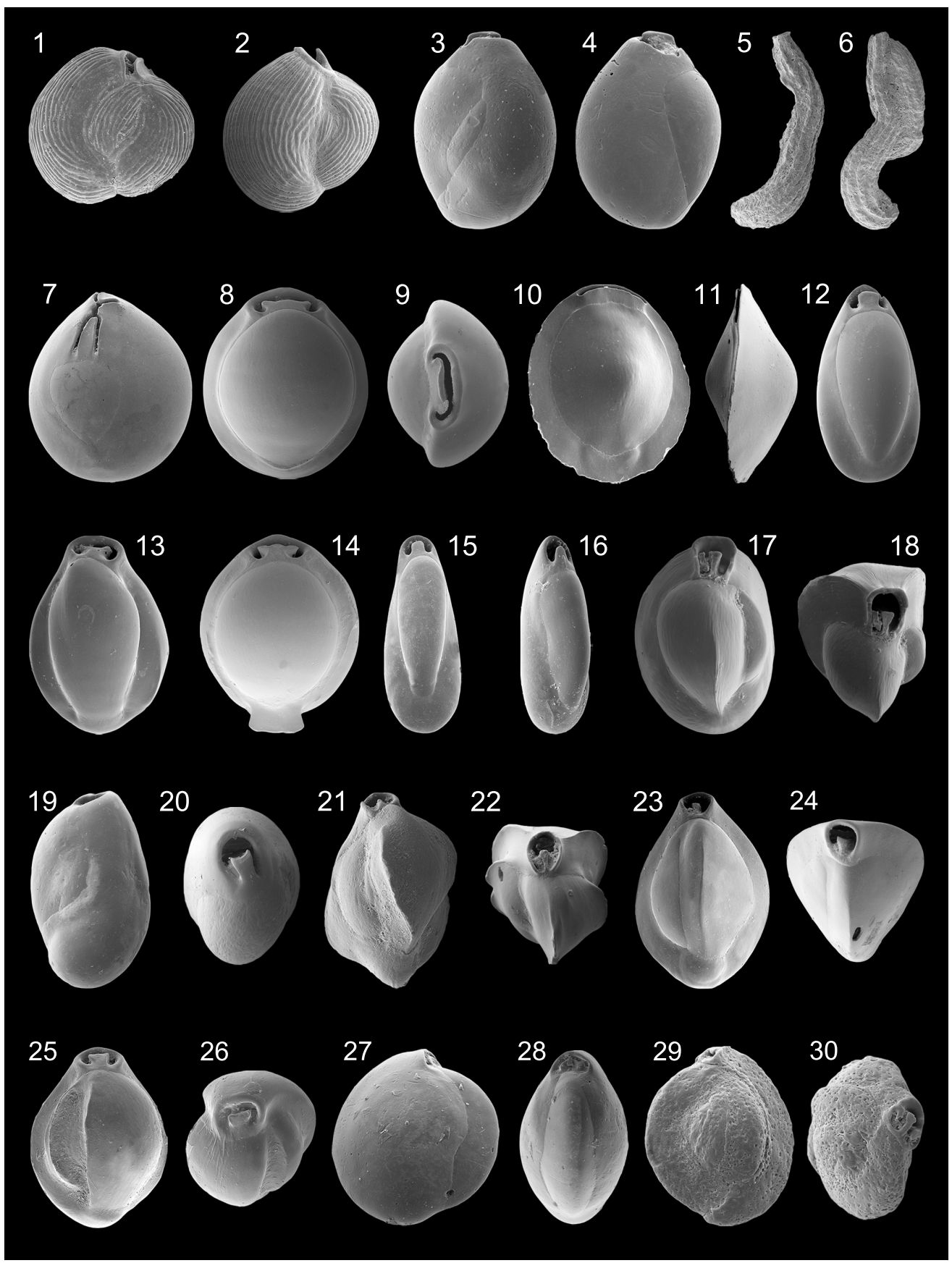

FIGURE 17. 1 Miliolinella webbiana (d'Orbigny), 263x, side view; 2 M. webbiana (d'Orbigny), 241x, side view; 3 Pseudotriloculina sp. 1, 901x, three chamber side; 4 Pseudotriloculina sp. 1, 930x, two chamber side; 5 Ptychomiliola separans? (Brady), 512x, lateral view; 6 P. separans? (Brady), 338x, lateral view; 7 Pyrgoella sphaera (d'Orbigny), 427x, lateral view; 8 Pyrgo anomala (Schlumberger), 310x, side view; $9 P$. anomala (Schlumberger), 305x, apertural edge view; 10 Pyrgo depressa (d’Orbigny), 314x, side view; 11 P. depressa (d’Orbigny), 229x, peripheral view; 12 Pyrgo elongata (d'Orbigny), 360x, side view; 13 Pyrgo oblonga (d’Orbigny), 420x, side view; 14 Pyrgo sp. 1, 307x, lateral view; 15 Pyrgo sp. 2, 753x, lateral view; 16 Pyrgo sp. 2, 853x, lateral view; 17 Triloculina marioni Schlumberger, 602x, profile view; 18 T. marioni Schlumberger, 574x, apertural edge view; 19 Triloculina oblonga (Montagu), 177x, three chamber side; 20 T. oblonga (Montagu), 317x, apertural edge view; 21 Triloculina plicata Terquem, 754x, profile view; 22 T. plicata Terquem, 424x, apertural edge view; 23 Triloculina tricarinata d'Orbigny, 778x, profile view; 24 T. tricarinata d'Orbigny, 701x, apertural edge view; 25 Triloculina sp. 1, 348x, profil view; 26 Triloculina sp. 1, 870x, apertural egde view; 27 Nummoloculina sp. 1, 437x, side view; 28 Nummoloculina sp. 1, 397x, peripheral view; 29 Pseudoschlumbergerina ovata (Sidebottom), 686x, side view; 30 P. ovata (Sidebottom), 725x, apertural edge view. 
1960 Pyrgo fischeri (Schlumberger); Hofker, p. 243, pl. B, fig. 56

1991 Pyrgo anomala (Schlumberger); Cimerman and Langer, p. 44, pl. 41, figs. 3-5

1993 Pyrgo anomala (Schlumberger); Sgarrella and Moncharmont Zei, p. 180, pl. 9, fig. 3

2009 Pyrgo anomala (Schlumberger); Milker et al., p. 216, pl. 2, figs. 1, 2

Remarks: The wall is porcelaneous and imperforate. The test is subrounded in lateral view and ovate in apertural view. The adult stage is "biloculine," and two chambers are visible from the exterior. The peripheral wall is separated from the lateral wall by rounded shoulders. The aperture is subelliptical, bordered by an everted rim and provided with a broad, bifid tooth. The test surface is smooth.

Pyrgo depressa (d'Orbigny, 1826)

Figure 17.10-11

1826 Biloculina depressa d'Orbigny: p. 298, no. 7

1884 Biloculina depressa d'Orbigny; Brady, p. 145, pl. 3, figs. 1, 2

1929 Pyrgo depressa (d'Orbigny); Cushman, p. 71, pl. 19, fig. 4

1958 Pyrgo depressa (d'Orbigny); Le Calvez and Le Calvez, p. 199, pl. 7, fig. 71

1960 Pyrgo depressa (d'Orbigny); Hofker, p. 243, pl. B, fig. 53

1990 Pyrgo depressa (d'Orbigny); Hasegawa et al., p. 475, pl. 2, fig. 1

1994 Pyrgo depressa (d'Orbigny); Jones, p. 19, pl. 3, figs. 1, 2 [cop Brady, 1884, figs. 1, 2]

2003 Biloculinella depressa (d'Orbigny); Murray, p. 15, fig. 4, no. 2, 3

2005 Pyrgo depressa (d'Orbigny); Rasmussen, p. 65 , pl. 4 , fig. 17

Remarks: The wall is porcelaneous and imperforate. The test is subrounded to rounded in lateral view and lenticular in apertural view. The adult stage is "biloculine," and two chambers are visible from the exterior. The peripheral wall is separated from the lateral wall by carinate shoulders. The aperture is a small slit of variable length. The test surface is smooth.

\section{Pyrgo elongata (d'Orbigny, 1826)}

Figure 17.12
1826 Biloculina elongata d'Orbigny: p. 298, no. 4

1884 Biloculina elongata (d'Orbigny); Brady, p. 144, pl. 2, fig. 9

1917 Biloculina elongata d'Orbigny; Cushman, p. 78 , pl. 31, fig. 1

1929 Pyrgo elongata (d'Orbigny); Cushman, p. 70, pl. 19, figs. 2, 3

1960 Pyrgo elongata (d'Orbigny); Hofker, p. 244, pl. B, fig. 58

1991 Pyrgo elongata (d'Orbigny); Cimerman and Langer, p. 44, pl. 41, figs. 6-8

1993 Pyrgo elongata (d'Orbigny); Sgarrella and Moncharmont Zei, p. 182, pl. 9, fig. 1

1994 Pyrgo elongata (d'Orbigny); Jones, p. 18, pl. 2, fig. 9 [cop. Brady, 1884, fig. 9]

Remarks: The wall is porcelaneous and imperforate. The test is elongate-ovate in lateral view and lenticular in apertural view. The adult stage is "biloculine," and two chambers are visible from the exterior. Chambers are inflated. The peripheral wall is separated from the lateral wall by rounded shoulders. The aperture is subtriangular and provided with a flap-like tooth. The test surface is smooth. The specimen shown in Sgarrella and Moncharmont Zei (1993) differs from that shown by the other authors, and from that in this work, by the more ovate test in lateral view.

$$
\text { Pyrgo oblonga (d'Orbigny, 1839a) }
$$

Figure 17.13

1839a Biloculina oblonga d'Orbigny: p. 163, pl. 8, figs. 21-23

1988 Pyrgo oblonga (d'Orbigny); Loeblich and Tappan, p. 94, pl. 351, figs. 11-13 [cop. d'Orbigny, 1839a, figs. 21-23]

1993 Pyrgo oblonga (d'Orbigny); Hottinger, Halicz and Reiss, p. 57, pl. 50, figs. 1-6

Remarks: The wall is porcelaneous and imperforate. The test is ovate in lateral view and in apertural view. The adult stage is "biloculine," and two chambers are visible from the exterior. Chambers are inflated. The peripheral wall is separated from the lateral wall by the broadly rounded shoulders. The ovate aperture is bordered by a rim and provided with a broad and bifid tooth. The test surface is smooth.

\section{Pyrgo sp. 1}

Figure 17.14

2006 Pyrgo elongata (d'Orbigny); Avsar et al., p. 132, pl. 1 , fig. 13 
Remarks: The wall is porcelaneous and imperforate. The test is subrounded in lateral view and ovate in apertural view. The adult stage is "biloculine," and two chambers are visible from the exterior. The peripheral wall is separated from the lateral wall by rounded shoulders. The aperture is subelliptical, bordered by a rim and provided with a broad and bifid tooth. The test surface is smooth. These specimens look close to Pyrgo anomala but have a rectangle-like attachment at the base of the test.

\section{Pyrgo sp. 2 \\ Figure 17.15-16}

Remarks: The wall is porcelaneous and imperforate. The test is very elongate in lateral view. Two chambers are visible from the exterior. Chambers are inflated. The peripheral wall is separated from the lateral wall by rounded shoulders. The aperture is ovate and provided with a flap-like tooth. The test surface is smooth. This species looks like a smaller, probably a juvenile(?) form of Pyrgo elongata. Further study is necessary.

Genus PYRGOELLA Cushman and White, 1936 Pyrgoella sphaera (d'Orbigny, 1839c)

\section{Figure 17.7}

1839c Biloculina sphaera d'Orbigny: p. 66, pl. 8, figs. 13-16

1884 Biloculina sphaera d'Orbigny; Brady, p. 141, pl. 2, fig. 4

1958 Pyrgoella sphaera (d'Orbigny); Le Calvez and Le Calvez, p. 198, pl. 7, fig. 72

1958 Pyrgoella sphaera (d'Orbigny); Parker, p. 256, pl. 1, fig. 14

1958 Pyrgoella sphaera (d'Orbigny); Todd, p. 188, pl. 1, fig. 4

1960 Planispirina sphaera (d'Orbigny); Hofker, p. 244, pl. B, fig. 59

1988 Pyrgoella sphaera (d'Orbigny); Loeblich and Tappan, p. 94, pl. 351, figs. 1-4

1991 Pyrgoella sphaera (d'Orbigny); Cimerman and Langer, p. 45, pl. 41, figs. 1, 2

1992 Pyrgoella sphaera (d'Orbigny); Wollenburg, p. 41, pl. 11, fig. 2

1994 Pyrgoella sphaera (d'Orbigny); Jones, p. 18, pl. 2, fig. 4 [cop. Brady, 1884, fig. 4]

Remarks: The wall is porcelaneous and imperforate. The test is globular. It has an early "pseudotriloculine" chamber arrangement and in the adult stage, a "biloculine" chamber arrangement, so that in the adult stage later chambers strongly overlap the preceding chambers. Two chambers are visible from the exterior in adult stage. The aperture is a triangular slit and additionally, a sinuate opening has been observed. The test surface is smooth.

Genus TRILOCULINA d'Orbigny 1826

Triloculina marioni Schlumberger, 1893

Figure 17.17-18

1893 Triloculina marioni Schlumberger: p. 204, pl. 1, figs. $38-41$; text-figs. 7,8

1893 Triloculina marioni Schlumberger; Le Calvez and Le Calvez, p. 191, pl. 6, figs. 54-56

1991 Triloculina marioni Schlumberger; Cimerman and Langer, p. 46, pl. 43, figs. $1-5$

Remarks: The wall is porcelaneous and imperforate. The test is ovate in lateral view and subtriangular in apertural view. Three chambers are visible from the exterior, increasing in size as added. The peripheral wall is broadly convex and separated from the lateral walls by acute shoulders. Sutures are depressed. The aperture is subrounded, bordered by a thin rim and provided with a relatively long and bifid tooth. The test is ornamented with microstriae.

Triloculina oblonga (Montagu, 1803) Figure 17.19-20

1803 Vermiculum oblongum Montagu: p. 522, pl. 14, fig. 9

1917 Triloculina oblonga (Montagu); Cushman, p. 69 , pl. 26 , fig. 3

1929 Triloculina oblonga (Montagu); Cushman, p. 57 , pl. 13 , fig. 4

1958 Triloculina oblonga (Montagu); Le Calvez and Le Calvez, p. 192 pl. 6, figs. 60, 61

1991 Pseudotriloculina oblonga (Montagu); Cimerman and Langer, p. 43, pl. 40, figs. 1-4

2005 Triloculina oblonga (Montagu); Debenay et al., p. 332, pl. 1, figs. 20,23

2005 Triloculina oblonga (Montagu); Rasmussen, p. 67, pl. 5, fig. 4

2009 Pseudotriloculina oblonga (Montagu); Avsar et al., p. 134, pl. 1, fig. 24

Remarks: The wall is porcelaneous and imperforate. The test is ovate in lateral view. Three chambers are visible from the exterior. The periphery is rounded. The aperture is subrounded and provided 
with a narrow and bifid tooth. The test surface is smooth. According to Cushman (1929), the tooth can also be broad and simple.

Triloculina plicata Terquem, 1878

Figure 17.21-22

1878 Triloculina plicata Terquem: p. 61, pl. 6, fig. 2

1915 Miliolina tricarinata (d'Orbigny) var. plicata (Terquem); Heron-Allen and Earland, p. 562, pl. 41, figs. $17-22$

1958 Triloculina plicata Terquem; Le Calvez and Le Calvez, p. 189, pl. 14, figs. 162, 163

1991 Triloculina plicata Terquem; Cimerman and Langer, p. 46, pl. 43, figs. 8-10

2005 Triloculina plicata Terquem; Rasmussen, p. 67 , pl. 5 , fig. 5

Remarks: The wall is porcelaneous and imperforate. The test is ovate in lateral view and polygonal in apertural view. Three inflated chambers are visible from the exterior, increasing in size as added. The chambers periphery is carinate, separating one chamber from the next. The aperture is subrounded and provided with a bifid tooth. The test surface is smooth.

Triloculina tricarinata d'Orbigny, 1826

Figure 17.23-24

1826

Triloculina tricarinata d'Orbigny: p. 299, no. 7

1884 Miliolina tricarinata (d'Orbigny); Brady, p. 165, pl. 3; fig. 17

1917 Triloculina tricarinata d'Orbigny; Cushman, p. 66 , pl. 25 , fig. 2

1929 Triloculina tricarinata d'Orbigny; Cushman, p. 56 , pl. 13 , fig. 3

1932 Triloculina tricarinata d'Orbigny; Cushman, p. 59 , pl. 13 , fig. 3

1958 Triloculina tricarinata d'Orbigny; Le Calvez and Le Calvez, p. 189, pl. 5, figs. 47, 48

1960 Triloculina tricarinata d'Orbigny; Hofker, $p$. 242, pl. B, fig. 47

1985 Triloculina tricarinata d'Orbigny; Hermelin and Scott, p. 218, pl. 2, fig. 7

1990 Triloculina tricarinata d'Orbigny; Hasegawa et al., p. 475, pl. 2, figs. 10, 11

1991 Triloculina tricarinata d'Orbigny; Cimerman and Langer, p. 46, pl. 44, figs. 3, 4
1993 Triloculina tricarinata d'Orbigny; Sgarrella and Moncharmont Zei, p. 187, pl. 9, figs. 14,15

1994 Triloculina tricarinata d'Orbigny; Jones, $p$. 20, pl. 3, fig. 17 [cop. Brady, 1884, fig. 17]

2004 Triloculina tricarinata d'Orbigny; Chendes et al., p. 76, pl. 1, fig. 11

2005 Triloculina tricarinata d'Orbigny; Rasmussen, p. 67 , pl. 5 , fig. 6

Remarks: The wall is porcelaneous and imperforate. The test is ovate in lateral view and triangular in apertural view. Three chambers are visible from the exterior. The chamber's periphery is carinate, separating one chamber from the next. The aperture is subrounded, bordered by a thin rim and provided with a short, bifid tooth. The test surface is smooth.

Triloculina sp. 1

Figure 17.25-26

Remarks: The wall is porcelaneous and imperforate. The test is ovate in lateral view. Three chambers are visible from the exterior. The final two chambers are broad, more inflated and angled on the periphery. The earlier and smaller chamber has a prominent flexuose keel on the periphery. The subrounded aperture is surrounded by a thickened peristomal rim and provided with a short, bifid tooth. The test surface is smooth.

\section{Subfamily SIGMOILINITINAE Luczkowska, 1974 \\ Genus NUMMOLOCULINA Steinmann, 1881 Nummoloculina sp. 1 \\ Figure 17.27-28}

1991 Nummoloculina sp. 1; Cimerman and Langer, p. 47, pl. 44, figs. 9-11

Remarks: The wall is porcelaneous and imperforate. The test is subcircular in lateral view and lenticular in peripheral view. Early chambers are arranged in a sigmoid manner, and later chambers are added in a single plane. Two chambers are visible from the exterior. Sutures are slightly depressed. The periphery is broadly rounded. The aperture is arch-shaped and provided with a flaplike tooth. The test surface is smooth.

\section{Genus PSEUDOSCHLUMBERGERINA Cherif, 1970}

Pseudoschlumbergerina ovata (Sidebottom, 1904) Figure 17.29-30

1904 Sigmoilina ovata Sidebottom: pp. 6-7, textfig. 1, pl. 2, figs. 12,13 
1915 Sigmoilina ovata Sidebottom; Heron-Allen and Earland, p. 584, pl. 45, figs. 16-18

1918 Sigmoilina ovata Sidebottom; Sidebottom, p. 9, pl. 2, figs. 3, 4

1988 Pseudoschlumbergerina ovata (Sidebottom); Loeblich and Tappan, p. 95, pl. 355, figs. 7-10 [figs. 7, 8: cop. Sidebottom, 1904, figs. 12, 13]

1990 Septloculina angulata (El Nakhal); EI Nakhal, p. 91, pl. 1, figs. 1-7; pl. 2, figs. 1-3

1993 Pseudoschlumbergerina ovata (Sidebottom); Hottinger, Halicz and Reiss, p. 55, pl. 46, figs. 1-6

Remarks: The wall is porcelaneous and imperforate. The test is ovate in lateral view and slightly compressed in apertural view. Two chambers per whorl are added in various planes, resulting in a sigmoid chamber arrangement. Up to seven chambers are visible from the exterior, five from one side and four from the other side. The aperture is archshaped with a lip and provided with a bifid tooth. The test surface is ornamented with fine and irregular microstriae, making it rough. Our specimens differ from that shown by the El Nakhal (1990) and Hottinger, Halicz and Reiss (2003) by their larger teeth. According to the original description of Sidebottom (1904), the tooth can vary from a small form to a well developed bifid form.

Genus SIGMOILINITA Seiglie, 1965b

Sigmoilinita costata (Schlumberger, 1893)

Figure 18.1-2

1893 Sigmoilina costata Schlumberger: p. 61, pl. 1, figs. 31, 32; text-fig. 4

1958 Sigmoilina costata Schlumberger; Le Calvez and Le Calvez, p. 208, pl. 7, figs. 69,70

1987 Sigmoilina costata Schlumberger; Alberola et al., p. 306, pl. 2, fig. 15

1991 Sigmoilinita costata (Schlumberger); Cimerman and Langer, p. 47, pl. 45, figs. 1-6

1993 Sigmoilina costata Schlumberger; Sgarrella and Moncharmont Zei, p. 184, pl. 9, figs. 6-8

2004 Sigmoilinita costata (Schlumberger); Fiorini, p. 50, pl. 1, figs. 8, 9

2005 Sigmoilinita costata (Schlumberger); Debenay et al., p. 332, pl. 1, fig. 9

2009 Sigmoilinita costata (Schlumberger); Avsar et al., p. 134, pl. 1, fig. 27
Remarks: The wall is porcelaneous and imperforate. The test is fusiform in lateral view and flattened in peripheral view. Chambers are arranged in different planes and later become nearly planispiral. The rounded aperture is on a neck, bordered by a thin rim and provided with a short tooth. The test surface is ornamented with longitudinal costae.

Sigmoilinita distorta (Phleger and Parker, 1951)

$$
\text { Figure 18.3-4 }
$$

1951 Sigmoilina distorta Phleger and Parker: $\mathrm{p}$. 8, pl. 4, figs. 3-5

1958 Sigmoilina distorta Phleger and Parker; Parker, p. 256, pl. 1, fig. 25

1974 Sigmoilina distorta Phleger and Parker; Luczowksa, p. 148, pl. 16, figs. 1-3

1993 Sigmoilina distorta Phleger and Parker; Sgarrella and Moncharmont Zei, p. 184, pl. 9, figs. 5

Remarks: The wall is porcelaneous and imperforate. The test is fusiform in lateral view and slightly irregularly biconvex and flattened in peripheral view. Early chambers are arranged in a sigmoid pattern, and later chambers are nearly planispirally arranged. The terminal aperture is rounded and provided with a short tooth. The test surface is smooth.

\section{Sigmoilinita sp. 1}

Figure 18.5-6

Remarks: The wall is porcelaneous and imperforate. The test is fusiform in lateral view and flattened in peripheral view. Chambers are one-half coil in length. Early chambers are arranged in a sigmoid pattern, and later chambers are nearly planispirally arranged. The periphery is acutely carinate. The aperture, at the end of the final chamber, is small and ovate to rounded. A tooth was not visible (probably broken?). The surface is ornamented with thick longitudinal costae. Our specimens looks close to Sigmoilina tricosta, illustrated in Sgarrella and Moncharmont Zei $(1993$, p. 185, plate 5, figures 8,9$)$ but clearly differ from the specimens originally described and illustrated as Spiroloculina tricosta in Cushman and Todd (1994, pp. 9, 10, 21, fig. 9, plate 3 , figures 26-29).

Subfamily SIGMOILOPSINAE Vella, 1957

Genus SIGMOILOPSIS Finlay, 1947

Sigmoilopsis schlumbergeri (Silvestri, 1904)

Figure 18.7-8

1884 Planispirina celata Costa sp.; Brady, pp.197-198, pl. 8, figs. 1-4 


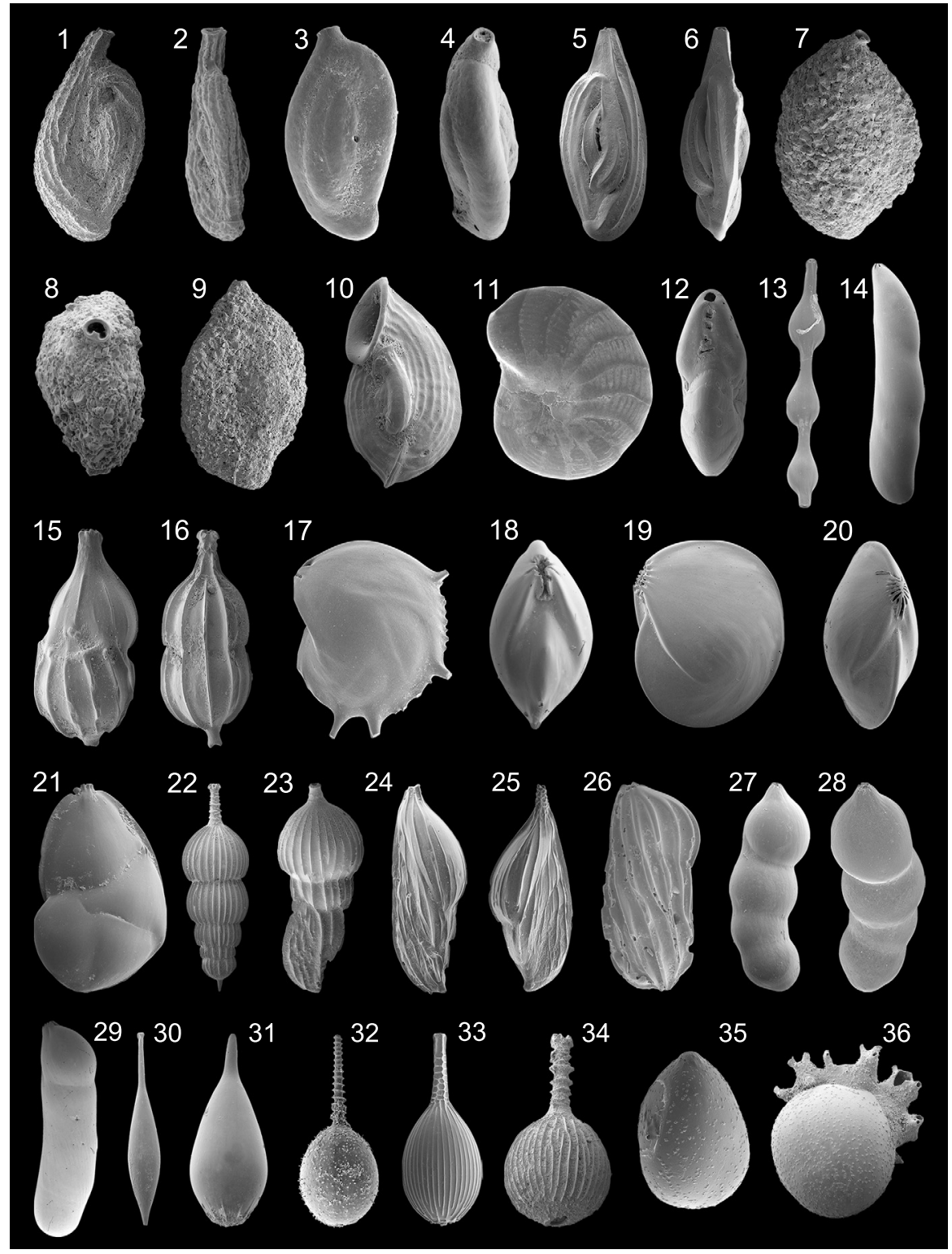

FIGURE 18. 1 Sigmoilinita costata (Schlumberger), 460x, side view; 2 S. costata (Schlumberger), 315x, peripheral view; 3 Sigmoilinita distorta (Phleger and Parker), 722x, side view; 4 S. distorta (Phleger and Parker), 396x, peripheral view; 5 Sigmoilinita sp. 1, 413x, side view; 6 Sigmoilinita sp. 1, 434x, peripheral view; 7 Sigmoilopsis schlumbergeri (Silvestri), 274x, side view; 8 S. schlumbergeri (Silvestri), 278x, apertural edge view; 9 Sigmoilopsis sp. 1, 172x, side view; 10 Articulina mucronata (d'Orbigny), 592x, side view; 11 Peneroplis pertusus (Forskal), 388x, side view; 12 P. pertusus (Forskal), 370x, peripheral view; 13 Dentalina guttifera d'Orbigny, 259x, lateral view; 14 Laevidentalina sp. 1, 1100x, lateral view; 15 Pyramidulina catesbyi (d'Orbigny), 586x, lateral view; 16 P. catesbyi (d'Orbigny), 516x, lateral view; 17 Lenticulina calcar (Linné), 438x, side view; 18 L. calcar (Linné), 201x, peripheral view; 19 Lenticulina orbicularis (d'Orbigny), 293x, side view; 20 L. orbicularis (d'Orbigny), 206x, peripheral view; 21 Neolenticulina peregrina (Schwager), 261x, side view; 22 Amphicoryna scalaris (Batsch), 242x, lateral view (macrospheric specimen); 23 A. scalaris (Batsch), 322x, lateral view (microspheric specimen); 24 A. scalaris (Batsch), 293x, lateral view (microspheric specimen); 25 A. scalaris (Batsch), 397x, lateral view (microspheric specimen); 26 Marginulina costata (Batsch), 304x, side view; 27 Hemirobulina sp.1, 137x, lateral view; 28 Hemirobulina sp.1, 229x, lateral view; 29 Vaginulina cf. americana Cushman, 97x, lateral view; 30 Hyalinonetrion gracillimum (Costa), 419x, lateral view; 31 Lagena doveyensis Haynes, 720x, lateral view; 32 Lagena hispida Reuss var. crispata Matthes, 560x, lateral view; 33 Lagena striata (d'Orbigny), 376x, lateral view; 34 Lagena strumosa Reuss, 356x, lateral view; 35 Globulina gibba var. punctata D'Orbigny, 193x, side view; 36 G. gibba var. punctata D'Orbigny, 162x, side view, specimen with fistulose overgrowth. 
1904 Sigmoilina schlumbergeri Silvestri: p. 267

1929 Sigmoilina schlumbergeri Silvestri; Cushman, p. 49 , pl. 11 , figs. 1-3

1960 Sigmoilina schlumbergeri Silvestri; Hofker, p. 244 , pl. C, fig. 61

1987 Sigmoilopsis schlumbergeri (Silvestri); Jorissen, p. 43, pl. 4, fig. 9

1988 Sigmoilopsis schlumbergeri (Silvestri); Loeblich and Tappan, p. 95, pl. 356, figs. 813 [figs. 11-13: cop. Brady 1884, figs. 1a, $2 b, 4]$

1993 Sigmoilopsis schlumbergeri (Silvestri); Sgarrella and Moncharmont Zei, p. 185, pl. 9, fig. 4

1994 Sigmoilopsis schlumbergeri (Silvestri); Jones, p. 23, pl. 8, figs. 1-4 [cop. Brady, 1884, figs. 1-4]

2004 Sigmoilopsis schlumbergeri (Silvestri); Chendes et al., p. 76, pl. 1, fig. 12

2005 Sigmoilopsis schlumbergeri (Silvestri); Rasmussen, p. 68 , pl. 5 , fig. 8

2008 Sigmoilopsis schlumbergeri (Silvestri); Abu-Zied et al., p. 51, pl. 1, figs. 18, 19

2009 Sigmoilopsis schlumbergeri (Silvestri); Avsar et al., p. 134, pl. 1, fig. 28

2009 Sigmoilopsis schlumbergeri (Silvestri); Frezza and Carboni, p. 57, pl. 2, fig. 21

Remarks: The wall is porcelaneous and overlained by a layer of agglutinated fine-grained material. The test is ovate in lateral view and lenticular in peripheral view. Early chambers are arranged in a sigmoid pattern, later chambers are planispirally arranged. Four to five chambers are poorly visible from the exterior. The rounded aperture is terminal, at the end of a short neck and provided with a short tooth.

\section{Sigmoilopsis sp. 1}

Figure 18.9

Remarks: The wall is porcelaneous and covered by a layer of irregularly arranged grains of different size. The test is ovate in lateral view and flattened in peripheral view. Early chambers are arranged in a sigmoid pattern, later chambers are planispirally arranged. Four to five chambers are poorly visible from the exterior. The rounded aperture is at the end of a short neck. This species differs from Sigmoilopsis schlumbergeri by the coarser-grained outer wall and by having a more inflated middle chamber.
Subfamily TUBINELLINAE Rhumbler, 1906

Genus ARTICULINA d'Orbigny, 1826

Articulina mucronata (d'Orbigny, 1839a)

Figure 18.10

1839a Vertebralina mucronata d'Orbigny: p. 52, pl. 7, figs. 16-19

1922c Vertebralina cassis d'Orbigny var. mucronata d'Orbigny; Cushman, p. 63

1993 Articulina mucronata (d'Orbigny); Sgarrella and Moncharmont Zei, p. 190, pl. 10, fig. 11

Remarks: The wall is porcelaneous. The test is ovate in lateral view and compressed in peripheral view. Earlier chambers are coiled, later chambers are uncoiled. The periphery is acutely carinate. The terminal and ovate aperture is bordered by an everted rim. The test surface is ornamented with longitudinal costae.

Family PENEROPLIDAE Schultze, 1854

Genus PENEROPLIS de Montfort, 1808

Peneroplis pertusus (Forskal, 1775)

Figure 18.11-12

1775 Nautilus pertusus Forskal: p. 125

1917 Peneroplis pertusus (Forskal); Cushman, p. 86 , pl. 37 , figs. $1,2,6$

1930a Peneroplis pertusus (Forskal); Cushman, p. 35, pl. 12, figs. 3-6

1991 Peneroplis pertusus (Forskal); Cimerman and Langer, p. 49, pl. 49, figs. 1-8

1993 Peneroplis pertusus (Forskal); Sgarrella and Moncharmont Zei, p. 190, pl. 10, fig. 13

1994 Peneroplis pertusus (Forskal); Jones, p. 29, pl. 13, figs. 16, 17, 23

2005 Peneroplis pertusus (Forskal); Debenay et al., p. 334, pl. 2, fig. 20

2009 Peneroplis pertusus (Forskal); Milker et al., p. 216 , pl. 2 , fig. 5

Remarks: The wall is porcelaneous. The test is planispirally enrolled, with a depressed umbilical region. Chambers are numerous, gradually increasing in size as added. The periphery is subrounded. Sutures are depressed. The aperture consists of numerous ovate or irregular openings. The openings are bordered by a rim. The test surface is ornamented with parallel grooves and rips.

Family SORITIDAE Ehrenberg, 1839

Subfamily ARCHAIASINAE Cushman, 1927 Genus PARASORITES Seiglie and Rivera, in 
Seiglie, Grove, and Rivera 1977)

Parasorites marginalis (Lamarck, 1816)

1816 Orbulites marginalis Lamarck: p. 196

1884 Orbitolites marginalis (Lamarck); Brady, p. 214, pl. 15, figs. 1-3, 5

1930 Sorites marginalis (Lamarck); Cushman, p. 49 , pl. 18 , figs. $1-4$

1994 Parasorites marginalis (Lamarck); Jones, p. 30 , pl. 15, figs. 1-3, 5 [cop. Brady, 1884, figs. $1-3,5]$

Remarks: The wall is porcelaneous. The large test is discoidal and biplanar. Chambers are subdivided by intradermal plates. The apertures consist of openings on the peripheral margin.

Suborder LAGENINA Delage and Herouard, 1896

Family NODOSARIIDAE Ehrenberg, 1838

Subfamily NODOSARIINEA Ehrenberg, 1838

Genus DENTALINA Risso, 1826

Dentalina guttifera d'Orbigny, 1846

Figure 18.13

1846 Dentalina guttifera d'Orbigny: p. 49, pl. 2, figs. 11,13

1993 Dentalina guttifera d'Orbigny; Sgarrella and Moncharmont Zei, p. 192, pl. 11, fig. 7

2005 Dentalina guttifera d'Orbigny; Debenay et al., p. 334, pl. 2, fig. 21

2005 Dentalina pyrula (d'Orbigny); Rasmussen, p. 69 , pl. 5 , fig. 13

Remarks: The wall is calcareous and hyaline. The test is elongate in lateral view. The chamber arrangement is uniserial and slightly arcuate. Chambers are subcylindrical and separated from each other by tubular sections. Chambers increasing continuously in size as added. The aperture is terminal and radiate. The base of the chambers is partly ornamented with some striae.

\section{Genus LAEVIDENTALINA Loeblich and Tappan, 1986 \\ Laevidentalina sp. 1}

Figure 18.14

Remarks: The wall is calcareous and hyaline. The test is elongate and slightly arcuate in lateral view. Chambers are uniserially arranged. Sutures are oblique. The aperture, at the dorsal edge, is terminal and consists of a serial of radial slits. The test surface is smooth.

Genus PYRAMIDULINA Fornasini, 1894

Pyramidulina catesbyi (d'Orbigny, 1839a)

Figure 18.15-16 1839a Nodosaria catesbyi d'Orbigny: p. 16, pl. 1, figs. 8-10

1931 Nodosaria catesbyi d'Orbigny; Cushman and Parker, p. 7, pl. 3, figs. 3, 4

1993 Pyramidulina catesbyi (d'Orbigny); Hottinger, Halicz and Reiss, p. 76, pl. 88, figs. 1-19

Remarks: The wall is calcareous and finely perforate. The test is elongate-ovate in lateral view. The chamber arrangement is uniserial and rectilinear. The first chamber is more globular and larger than the second that is more pyriform. The terminal aperture is radiate. According to Hottinger, Halicz and Reiss (1993), this species show variable morphological features such as different number of chambers, different chamber shapes and a different ornamentation with costae. Only specimens having two chambers have been found.

Family VAGINULINIDAE Reuss, 1860

Subfamily LENTICULININAE Chapman, Parr and Collins, 1934

Genus LENTICULINA Lamarck, 1804

Lenticulina calcar (Linné, 1758)

Figure 18.17-18

1758 Nautilus calcar Linné: p. 709

1846 Robulina calcar d'Orbigny: p. 99, pl. 4, figs. 18-20

1884 Cristellaria calcar (Linné); Brady, p. 551, pl. 70, figs. 9-12

1923 Cristellaria calcar (Linné); Cushman, p. 115, pl. 30, fig. 7; pl. 31, figs. 4, 5

1933c Robulina calcar (Linné); Cushman, p. 7, pl. 2, fig. 3

1991 Lenticulina calcar (Linné); Cimerman and Langer, p. 51, pl. 53, figs. 1-4

1993 Lenticulina calcar (Linné); Sgarrella and Moncharmont Zei, p. 194, pl. 12, fig. 11

1994 Lenticulina calcar (Linné); Jones, p. 81, pl. 70, figs. 9-12 [cop. Brady, 1884, figs. 9-12]

2005 Lenticulina calcar (Linné); Rasmussen, p. 69 , pl. 6 , fig. 5

Remarks: The wall is calcareous and hyaline. The test planispirally enrolled, rounded in lateral view and lenticular in peripheral view. The periphery is carinate, and pseudospines are present. Sutures are backward curved. The aperture is radiate, accompanied by a slit-like opening and bordered by two large flaps. The test surface is smooth. 
Lenticulina orbicularis (d'Orbigny, 1826)

Figure 18.19-20

1826 Robulina orbicularis d'Orbigny: p. 288, pl. 15, figs. 8,9

1884 Cristellaria orbicularis (d'Orbigny); Brady, p. 549 , pl. 69 , fig. 17

1923 Cristellaria orbicularis (d'Orbigny); Cushman, p. 101, pl. 21, fig. 7

1991 Lenticulina orbicularis (d'Orbigny); Cimerman and Langer, p. 51, pl. 53, fig. 12

1993 Lenticulina orbicularis (d'Orbigny); Sgarrella and Moncharmont Zei, p. 194, pl. 12, fig. 8

1994 Lenticulina orbicularis (d'Orbigny); Jones, p. 81, pl. 69, fig. 17 [cop. Brady, 1884, fig. 17]

2005 Lenticulina orbicularis (d'Orbigny); Rasmussen, p. 70 , pl. 6 , fig. 8

Remarks: The wall is calcareous and hyaline. The test planispirally enrolled, rounded in lateral view and lenticular in peripheral view. The periphery is carinate. Sutures are backward curved. The aperture is radiate, accompanied by a slit-like opening and bordered by two small flaps. The test surface is smooth.

Genus NEOLENTICULINA McCulloch, 1977 Neolenticulina peregrina (Schwager, 1866)

Figure 18.21

1866 Cristellaria peregrina Schwager: p. 245, pl. 7, fig. 8

1884 Cristellaria variablis (Reuss); Brady, $\mathrm{p}$. 541, pl. 68, figs. $11-16$

1923 Cristellaria peregrina Schwager; Cushman, p. 113, pl. 30, figs. 3, 4

1960 Lenticulina peregrina (Schwager); Hofker, p. 245 , pl. C, fig. 71

1988 Neolenticulina peregrina (Schwager); Loeblich and Tappan, p. 115, pl. 447, figs. 912,16

1993 Neolenticulina peregrina (Schwager); Sgarrella and Moncharmont Zei, p. 195, pl. 12, fig. 4

1994 Neolenticulina variablis (Reuss); Jones, p. 80 , pl. 68 , figs. 11-16 [cop. Brady 1884, figs. 11-16]

2005 Lenticulina peregrina (Schwager); Rasmussen, p. 70 , pl. 6 , fig. 9
Remarks: The wall is calcareous and hyaline. The test is planispirally enrolled, ovate in lateral view and compressed in apertural view. Chambers are semicircular and of enlarging size in each whorl. Three to five chambers are visible from the exterior. The final chamber in the adult stage is uncoiled. Sutures are depressed. The periphery is carinate. The aperture consists of multiple openings, each of them on a short tubular neck. The test surface is smooth.

Subfamily MARGINULININAE Wedekind, 1937

Genus AMPHICORYNA Schlumberger, in MilneEdwards 1881 Amphicoryna scalaris (Batsch, 1791)

Figure 18.22-25

1791 Nautilus (Ortoceras) scalaris Batsch: p. 2, pl. 2, fig. 4a, b

1884 Nodosaria scalaris (Batsch), sp.; Brady, p. 510, pl. 63, figs. 28-31

1884 Amphycorine falx (Jones and Parker), sp.; Brady, p. 556, pl. 65, figs. 7-9

1958 Lagenonodosaria scalaris (Batsch); Parker, p. 258, pl. 1, figs. 32, 33

1960 Nodogenerina scalaris (Batsch); Hofker, p. 244, pl. C, figs. 63-65

1988 Amphicoryna scalaris (Batsch); Loeblich and Tappan, p. 116, pl. 450, figs. 11-14

1991 Amphicoryna scalaris (Batsch); Cimerman and Langer, p. 52, pl. 54, figs. 1-9

1993 Amphicoryna scalaris (Batsch); Sgarrella and Moncharmont Zei, p. 191, pl. 11, figs. 2, 3

1994 Amphicoryna scalaris (Batsch); Jones, p. 75, pl. 63, figs. 28-31; pl. 65, figs. 7-9 [cop. Brady, 1884, figs. 28-31; 7-9]

2003 Amphicoryna scalaris (Batsch); Murray, p. 17, fig. 5, no. 1

2004 Amphicoryna scalaris (Batsch); Chendes et al., p. 76, pl. 1, fig. 14

2008 Amphicoryna scalaris (Batsch); Abu-Zied et al., p. 51, pl. 1, figs. 21, 22

2009 Amphicoryna scalaris (Batsch); Frezza and Carboni, p. 57, pl. 2, figs. 19, 20

2009 Amphicoryna scalaris (Batsch); Milker et al., p. 216, pl. 2, figs. 9, 10

Remarks: The wall is calcareous. The test is elongate. In the megalospheric form, the proloculus is followed by rectilinearly and uniserially arranged global chambers, increasing in size as added. 
Sutures are depressed. In the microspheric form, the first chambers are arranged in astacoline coil so that they are triangular in outline, with sharp angles on the periphery and with oblique sutures. Later chambers are arranged such as in the megalospheric form. The crown-like or radiate aperture, on a long neck, is covered by concentric ridges. The test surface is ornamented with long and numerous striae. An apiculate spine may be present at the base of the test.

\section{Genus HEMIROBULINA Stache, 1864 Hemirobulina sp. 1 \\ Figure 18.27-28}

Remarks: The wall is calcareous and hyaline. The test is elongate in lateral view and circular in section. The subglobular chambers are firstly added in a slight curve and later become rectilinear. Chambers gradually increasing in size as added. Sutures are oblique and depressed. The aperture is terminal at the dorsal edge. The test surface is smooth.

Genus MARGINULINA d'Orbigny, 1826 Marginulina costata (Batsch, 1791)

Figure 18.26

1791 Nautilus costatus Batsch: p. 2, pl. 1, fig. 1 a-g

1884 Marginulina costata (Batsch), sp.; Brady, p. 528, pl. 65, fig. 13

1923 Marginulina costata (Batsch); Cushman, p. 132, pl. 37, fig. 2

1993 Marginulina costata (Batsch); Sgarrella and Moncharmont Zei, p. 195, pl. 12, fig. 5

1994 Marginulina costata (Batsch); Jones, p. 77, pl. 65, fig. 13 [cop. Brady 1884, fig. 13]

2005 Marginulina costata (Batsch); Rasmussen, p. 71 , pl. 6 , fig. 17

Remarks: The wall is calcareous and hyaline. The test is elongate in lateral view. The early stage is slightly curved, and later chambers are rectilinearly arranged. Sutures are oblique and depressed. The aperture is radiate and terminal at the dorsal edge. The test surface is ornamented with thick longitudinal and slightly curved costae.

Subfamily VAGINULININAE Reuss, 1860

Genus VAGINULINA d'Orbigny, 1826

Vaginulina cf. americana Cushman, 1923

Figure 18.29

1884 cf. Vaginulina linearis Montagu; Brady, p. 532, pl. 67, figs. $10-12$

1923 cf. Vaginulina americana Cushman: p. 135 , pl. 38 , figs. 3,4
1994 cf. Vaginulina americana Cushman; Jones 1994 , p. 79 , pl. 67 , figs. 10-12 [cop. Brady, 1884, figs. 10-12]

Remarks: The wall is calcareous. The test is elongate, slightly arcuate and laterally slightly compressed. Chambers are uniserially arranged. The dorsal chamber margin is straight and the ventral margin is slightly inflated. Sutures are oblique in the early portion and later nearly horizontal and depressed. The terminal aperture is radiate at the dorsal edge. The test is ornamented with a few, long and curved striae. In difference to the specimens shown by the Brady (1884), Cushman (1923) and Jones (1994), our specimens have only a few striae on the test.

Family LAGENIDAE Reuss, 1862

Genus HYALINONETRION Patterson and Richardson, 1987

Hyalinonetrion gracillimum (Costa, 1856)

Figure 18.30

1856 Amphorina gracilis Costa: p. 125, pl. 11, fig. 11

1862 Amphorina gracillima Seguenza: p. 51, pl. 1, fig. 37

1884 Lagena gracillima (Seguenza); Brady, p. 456, pl. 56, figs. 19-22, 24-29

1923 Lagena gracillima (Seguenza); Cushman, p. 23 , pl. 4 , fig. 5

1991 Hyalinonetrion gracillimum (Seguenza); Cimerman and Langer, p. 52, pl. 55, figs. 1, 2

1993 Hyalinonetrion gracillis (Costa); Hottinger, Halicz and Reiss, p. 78, pl. 90, figs. 7, 8

1994 Procerolagena gracillima (Seguenza); Jones, p. 62, pl. 56, figs. 19-22, 24-29 [cop. Brady, 1884, figs. 19-22, 24-29]

2005 Lagena gracillima (Seguenza); Rasmussen, p. 72, pl. 7, figs. 4,5

2009 Hyalinonetrion gracillimum (Seguenza); Avsar et al., p. 134, pl. 2, fig. 1

Remarks: The wall is calcareous and hyaline. The test is very elongate, unilocular and tapering on both ends. The aperture is terminal and rounded, on a long, tapering neck and bordered by an everted rim. The test surface is smooth.

Genus LAGENA Walker and Jacob, 1798 Lagena doveyensis Haynes, 1973

Figure 18.31 
1973 Lagena doveyensis Haynes: p. 82, pl. 12, figs. 7, 8

1991 Lagena doveyensis Haynes; Cimerman and Langer, p. 53, pl. 55, figs. 3-5

2009 Lagena doveyensis Haynes; Avsar et al., p. 134 , pl. 2, fig. 2

Remarks: The wall is calcareous and hyaline. The test is unilocular and pear-shaped. The rounded aperture is on a long, tapering neck and bordered by an everted rim. Short longitudinal striae are present at the base of the test.

Lagena hispida Reuss var. crispata Matthes, 1939 Figure 18.32

1884 Lagena hispida Reuss; Brady, p. 459, pl. 63 , fig. 3

1923 Lagena hispida Reuss; Cushman, p. 26, pl. 4 , fig. 8

1939 Lagena hispida Reuss var. crispata Matthes: p. 61, pl. 3, fig. 21

1994 Lagena aspera var. crispata (Matthes); Jones, p. 63, pl. 57, fig. 3 [cop. Brady, 1884, fig. 3]

Remarks: The wall is calcareous and hyaline. The test is unilocular and ovate. The aperture is on a long and slender neck that is ornamented with oblique ridges. The test surface is ornamented with short pseudospines.

Lagena striata (d'Orbigny, 1839c)

Figure 18.33

1839c Oolina striata d'Orbigny: p. 21, pl. 5, fig. 12

1884 Lagena striata (d'Orbigny); Brady, p. 460, pl. 57 , figs. 22,24

1923 Lagena striata (d'Orbigny); Cushman, p. 54 , pl. 10 , fig. 9

1933c Lagena striata (d'Orbigny); Cushman, p. 32, pl. 8, figs. 11,13

1991 Lagena striata (d'Orbigny); Cimerman and Langer, p. 53, pl. 55, figs. 6-7

1992 Lagena striata (d'Orbigny); Wollenburg, $p$. 46 , pl. 12 , fig. 3

1993 Lagena striata (d'Orbigny); Sgarrella and Moncharmont Zei, p. 198, pl. 12, figs. 2-3

1994 Lagena striata (d'Orbigny); Jones, p. 64, pl. 57, figs. 22, 24 [cop. Brady, 1884, figs. 22, 24]

2005 Lagena striata (d'Orbigny); Rasmussen, p. 73 , pl. 7 , fig. 8
2006 Lagena striata (d'Orbigny); Avsar et al., p. 134 , pl. 2, figs. 3,4

Remarks: The wall is calcareous and hyaline. The test is unilocular and pear-shaped. The crown-like aperture is on a long neck that is ornamented with polygonally arranged ridges. The test surface is ornamented with numerous longitudinal striae. An apical pseudospine is present.

\section{Lagena strumosa Reuss, 1858}

Figure 18.34

1858 Lagena strumosa Reuss: p. 434

1863 Lagena strumosa Reuss; Reuss, p. 328, pl. 4 , fig. 49

1913 Lagena striata (d'Orbigny) var. strumosa Reuss; Cushman, p. 20, pl. 7, figs. 7-10

1993 Lagena strumosa Reuss; Hottinger, Halicz and Reiss, p. 79, pl. 90, figs. 18-25

2002 Amphycorina proxima (Silvestri); Kaminski et al., p. 173, pl. 2, fig. 5

Remarks: The wall is calcareous. The test is unilocular with a globular chamber. The crown-like aperture is on a long neck that is covered by concentric ridges. The test surface is ornamented with longitudinal striae and perforate.

Family POLYMORPHINIDAE d'Orbigny, 1839 Subfamily POLYMORPHININAE d'Orbigny, 1839 Genus GLOBULINA d'Orbigny, 1839

Globulina gibba d'Orbigny var. punctata d'Orbigny, 1846

Figure 18.35-36

1846 Globulina punctata d'Orbigny: p. 229, pl. 13, figs. 17,18

1991 Globulina? punctata d'Orbigny; Cimerman and Langer, p. 54, pl. 56, figs. 5-7

1993 Globulina gibba (d'Orbigny); Hottinger, Halicz and Reiss, p. 79, pl. 91, figs. 6-12

2005 Globulina gibba (d'Orbigny); Rasmussen, p. 74, pl. 7, fig. 12

Remarks: The wall is calcareous and finely perforate. The test is ovoid with a "quinqueloculine" chamber arrangement. The terminal aperture is radiate and may be covered by a fistulose overgrowth. The test surface is ornamented with pustules.

Globulina myristiformis (Williamson, 1858) Figure 19.1

1858 Polymorphina myristiformis Williamson: $p$. 73, pl. 6, figs. 156,157 


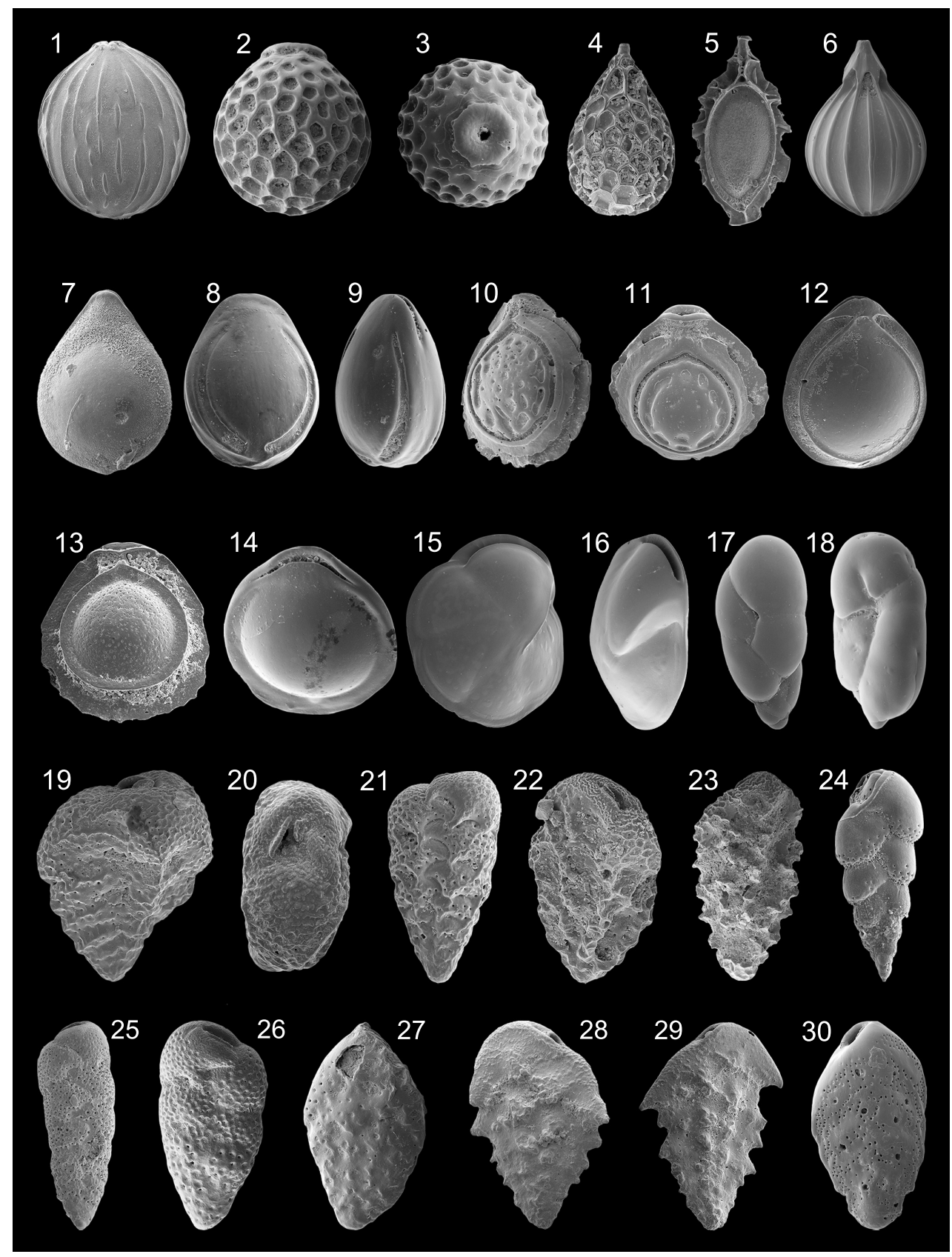

FIGURE 19. 1 Globulina myristiformis (Williamson), 374x, lateral view; 2 Favulina foveolata (Seguenza), 446x, lateral view; 3 F. foveolata (Seguenza), 510x, apertural view; 4 Favulina hexagona (Williamson), 592x, lateral view; 5 Lagnea sp. 1, 588x, lateral view; 6 Oolina acuticosta (Reuss), 634x, lateral view; 7 Fissurina crebra (Matthes), 1040x, lateral view; 8 Fissurina fasciata (Egger), 1020x, lateral view; 9 F. fasciata (Egger), 749x, oblique lateral view; 10 Fissurina lacunata (Burrows and Holland), 506x, lateral view; 11 F. lacunata (Burrows and Holland), 826x, oblique lateral view; 12 Fissurina marginata (Montagu), 505x, lateral view; 13 Fissurina orbignyana Seguenza, 882x, lateral view; 14 Parafissurina lateralis (Cushman) var. carinata (Buchner), 892x, oblique lateral view; 15 Hoeglundina elegans (d'Orbigny), 295x, umbilical side; $16 \mathrm{H}$. elegans (d'Orbigny), 242x, peripheral view; 17 Robertina translucens Cushman and Parker, 828x, lateral view; 18 R. trans/ucens Cushman and Parker, 433x, lateral view; 19 Bolivina cistina Cushman, 1020x, lateral view; 20 B. cistina Cushman, 1390x, apertural face; 21 Bolivina plicatella Cushman, 910x, lateral view; 22 Bolivina pseudoplicata Heron-Allen and Earland, 1070x, lateral view; 23 B. pseudoplicata Heron-Allen and Earland, 946x, lateral view; 24 Bolivina subspinescens Cushman, 1110x, lateral view; 25 Bolivina variabilis (Williamson), 549x, lateral view; 26 B. variabilis (Williamson), 732x, lateral view; 27 Bolivina sp. 1, 735x, lateral view; 28 Brizalina difformis (Williamson), 904x, lateral view; 29 B. difformis (Williamson), 722x, lateral view; 30 Brizalina dilatata (Reuss), 824x, lateral view. 
1884 Polymorphina myristiformis Williamson; Brady, p. 571, pl. 73, figs. 9, 10

1923 Polymorphina myristiformis Williamson; Cushman, p. 158, pl. 41, figs. 9-12

1991 Globulina myristiformis (Williamson); Cimerman and Langer, p. 53, pl. 56, figs. 13,14

1994 Globulina myristiformis (Williamson); Jones, p. 85, pl. 73, figs. 9, 10 [cop. Brady, 1884, figs. 9, 10]

2005 Globulina gibba d'Orbigny var. myristiformis (Williamson); Rasmussen, p. 74, pl. 7, fig. 13

Remarks: The wall is porcelaneous. The test is ovate and circular in section. The aperture is terminal and radiate. The test surface is ornamented with longitudinal costae, extending from the aperture to the base or ending abruptly.

Family ELLPISOLAGENIDAE Silvestri, 1923 Subfamily OOLININAE Loeblich and Tappan, 1961 Genus FAVULINA Patterson and Richardson, 1987 Favulina foveolata (Seguenza, 1862)

Figure 19.2-3

1862 Orbulina foveolata Seguenza: p. 37, pl. 1, figs. 1, 2

1940 Lagena foveolata (Seguenza); Buchner, p. 438 , pl. 6 , figs. $85-87$

1993 Oolina foveolata (Seguenza); Sgarrella and Moncharmont Zei, p. 199, pl. 12, fig. 14

Remarks: The wall is calcareous and translucent. The unilocular test is globular. The terminal aperture is rounded and bordered by a thin rim. The test surface is ornamented with polygonally arranged ridges.

Favulina hexagona (Williamson, 1848)

Figure 19.4

1848 Entesolenia squamosa (Montagu) var. hexagona Williamson: p. 20, pl. 2, fig. 23

1884 Lagena hexagona (Williamson); Brady, p. 472, pl. 58, fig. 33

1923 Lagena hexagona (Williamson); Cushman, p. 24, pl. 4, fig. 6 [cop. Williamson, 1848, fig. 23]

1985 Oolina hexagona (Williamson); Hermelin and Scott, p. 214, pl. 2, fig. 10

1988 Favulina hexagona (Williamson); Loeblich and Tappan, p. 120, pl. 463, figs. 1, 2
1991 Favulina hexagona (Williamson); Cimerman and Langer, p. 55, pl. 58, figs. 8, 9

1992 Favulina hexagona (Williamson); Wollenburg, p. 46, pl. 12, fig. 9

1993 Oolina hexagona (Williamson); Sgarrella and Moncharmont Zei, p. 199, pl. 12, fig. 15

1994 Oolina hexagona (Williamson); Jones, p. 66 , pl. 58, fig. 33 [cop. Brady, 1884, fig. 33]

2004 Favulina hexagona (Williamson); Chendes et al., p. 76, pl. 1, fig. 16

2005 Oolina hexagona (Williamson); Rasmussen, p. 76 , pl. 8, fig. 10

2010 Oolina hexagona (Williamson); Milker, p. 199, pl. 3, fig. 9

Remarks: The wall is calcareous and translucent. The unilocular test is pear-shaped. The aperture is terminal and rounded on a short neck. The test surface is ornamented with polygonally arranged ridges.

\section{Genus LAGNEA Popescu, 1983 Lagnea sp. 1 \\ Figure 19.5}

Remarks: The wall is calcareous, hyaline and finely perforate. The test is unilocular, flask-shaped and compressed. The periphery is broadly carinate with plate-like struts, forming polygonal and tubular structures that extend completely around the periphery. The terminal aperture, at the end of a neck, is rounded and bordered by a thickened rim.

$$
\begin{gathered}
\text { Genus OOLINA d'Orbigny, } 1839 \\
\text { Oolina acuticosta (Reuss, 1861) } \\
\text { Figure } 19.6
\end{gathered}
$$

1861 Lagena acuticosta Reuss: p. 305, pl. 1, fig. 4

1863 Lagena acuticosta Reuss; Reuss, p. 331, pl. 5 , fig. 63

1923 Lagena acuticosta Reuss; Cushman, p. 5, pl. 1, figs. 1-3

1931 Lagena acuticosta Reuss; Wiesner, p. 117, pl. 18, figs. 208-210

1940 Lagena acuticosta Reuss; Buchner, p. 429, pl. 4, figs. 68,69

1933c Lagena acuticosta Reuss; Cushman, p. 34, pl. 8, figs. 9, 10, 12

1983 Oolina acuticosta (Reuss); Boltovskoy and Guissani de Kahn, p. 301, pl. 1, figs. 8, 9 
1993 Oolina acuticosta (Reuss); Sgarrella and Moncharmont Zei, p. 199, pl. 12, fig. 12

2006 Oolina acuticosta (Reuss); Avsar et al., p. 133 , pl. 1 , fig. 17

Remarks: The wall is calcareous. The unilocular test is subglobular with the greatest breadth at the middle of the test or below. The terminal aperture is rounded. The test base ends in a slightly spinose projection of long costae, covering the test surface from the aperture to the base. Wiesner (1931) figured also a specimen with two subglobular and uniserially arranged chambers.

Subfamily ELLIPSOLAGENINAE Silvestri, 1923 Genus FISSURINA Reuss, 1850 Fissurina castanea (Flint, 1899)

1899 Lagena castanea Flint: p. 307, pl. 54, fig. 3

1923 Lagena castanea Flint; Cushman, p. 9, pl. 1, figs. 12,13

1940 Lagena castanea Flint; Buchner, p. 496, pl. 18, figs. $369-373$

1993 Fissurina castanea (Flint); Sgarrella and Moncharmont Zei, p. 201, pl. 13, fig. 10

Remarks: The wall is calcareous, hyaline and finely perforate. The test is subrounded outline and ovate in section. The peripheral margin is carinate. The aperture is terminal and slit-like. An apical appendix with a broad slit-like opening is present.

Fissurina crebra (Matthes, 1939)

Figure 19.7

1939 Lagena crebra Matthes: p. 72, pl. 5, figs. 66-70

1983 Fissurina crebra (Matthes); Boltovskoy and Guissani de Kahn, p. 301, pl. 1, figs. 1, 2

Remarks: The wall is calcareous, hyaline and finely perforate. The test is ovate in outline and lenticular in section. The peripheral margin is carinate. The terminal aperture is slit-like and bordered by a slightly produced rim. The test surface is smooth.

Fissurina fasciata (Egger, 1857)

Figure 19.8-9

1857 Oolina fasciata Egger: p. 8, pl. 1, figs. 1215

1863 Lagena fasciata (Egger); Reuss, p. 323, pl. 2 , fig. 24

1940 Lagena fasciata (Egger); Buchner, p. 479, pl. 15, figs. 262-265

1983 Fissurina fasciata (Egger); Boltovskoy and Guissani de Kahn, p. 301, pl. 2, figs. 6, 7
2005 Fissurina lucida (Williamson); Debenay et al., p. 336, pl. 3, fig. 10

Remarks: The wall is calcareous, hyaline and finely perforate. The test is ovate in outline. Two prominent keels are visible on the periphery. The aperture is terminal and slit-like.

Fissurina lacunata (Burrows and Holland, in Jones 1895)

Figure 19.10-11

1884 Lagena castrensis (Schwager): Brady, p. 485 , PI. 60 , figs. 1,2

1895 Lagena orbignyana Seguenza var. lacunata Burrows and Holland: type reference Jones, 1895, p. 202, pl. 7, fig. 12a, b

1923 Lagena lacunata Burrows and Holland: Cushman, p. 28, pl. 4, figs. 12, 13

1933c Lagena orbignyana Seguenza var. lacunata Burrows and Holland; Cushman, p. 27, pl. 7, figs. $1-5,8$

1994 Fissurina castanea (Burrows and Holland); Jones, p. 69, pl. 60, figs. 1, 2 [cop. Brady, 1884, figs. 1, 2]

2005 Fissurina orbignyana Seguenza var. lacunata (Burrows and Holland); Rasmussen, p. 77 , pl. 9 , fig. 4

Remarks: The wall is calcareous and hyaline. The test is ovate in outline and subovate in section. On the periphery, three prominent keels are present, whereby the middle is more elevated. The aperture is terminal, slit-like and bordered by a lip. The test surface is ornamented with irregularly arranged pittings and perforations.

Fissurina marginata (Montagu, 1803) Figure 19.12

1803 Vermiculum marginatum Montagu: p. 524

1884 Lagena marginata Walker and Boys; Brady, p. 476, pl. 59, figs. 21, 22

1964 Fissurina marginata (Montagu); Parker, p. 265, pl. 98, fig. 11

1994 Fissurina submarginata Boomgaart; Jones, p. 68, pl. 59, figs. 21, 22 [cop. Brady, 1884, figs. 21, 22]

2003 Fissurina marginata (Montagu); Murray, p. 17, fig. 5 , no. 3,4

Remarks: The wall is calcareous, hyaline and finely perforate. The test is subrounded in outline and subovate in section. On the periphery, three prominent keels are visible, whereby the middle is 
more elevated. The aperture is terminal and slitlike. The test surface is smooth.

Fissurina orbignyana Seguenza, 1862

Figure 19.13

1862 Fissurina orbignyana Seguenza: p. 66, pl. 2, figs. 25,26

1933c Lagena orbignyana (Seguenza); Cushman, p. 26, pl. 6 , figs. $7,8,11$

1939 Lagena orbignyana (Seguenza); Matthes, p. 80 , pl. 6 , fig. 104

1991 Palliolatella orbignyana (Seguenza); Cimerman and Langer, p. 56, pl. 59, figs. 5-7

2003 Fissurina orbignyana Seguenza; Murray, p. 17 , fig. 5 , no. 5,6

2005 Fissurina orbignyana Seguenza; Rasmussen, p. 77 , pl. 9, figs. 2,3

Remarks: The wall is calcareous, hyaline and densely perforate. The test is subrounded in outline and subovate in section. On the periphery, three prominent keels are present, whereby the middle is more elevated. The aperture is terminal, slit-like and bordered by a lip.

Subfamily PARAFISSURININAE Jones, 1984 Genus PARAFISSURINA Parr, 1947

Parafissurina lateralis (Cushman) var. carinata (Buchner, 1940)

Figure 19.14

1940 Lagena lateralis Cushman var. carinata Buchner: p. 521, pl. 23, figs. 497-500

1983 Parafissurina lateralis carinata (Buchner); Boltovskoy and Guissani de Kahn, p. 303, pl. 1, fig. 28

1993 Parafissurina lateralis (Cushman); Sgarrella and Moncharmont Zei, p. 205, pl. 13, fig. 11

2004 Parafissurina carinata (Buchner); Popescu and Crihan, p. 412, pl. 5, figs. 3, 4

Remarks: The wall is calcareous and hyaline. The test is subrounded in outline and subovate in section. The peripheral margin is weakly carinate. The aperture is subterminal and crescentic. The test surface is smooth.

Family CERATOBULIMINIDAE Cushman, 1927 Subfamily CERATOBULIMININAE Cushman, 1927 Genus LAMARCKINA Berthelin, 1881 Lamarckina scabra (Brady, 1884)

1884 Pulvinulina oblonga (Williamson) var. scabra Brady: p. 689 , pl. 106, fig. 8
1931 Lamarckina scabra (Brady); Cushman, p. 35, pl. 7, fig. 6 [cop. Brady, 1884, fig. 8]

1993 Lamarckina scabra (Brady); Sgarrella and Moncharmont Zei, p. 242, pl. 26, figs. 3, 4

1994 Ceratocancris scaber (Brady); Jones, $p$. 105, Pl. 60, fig. 8 [cop. Brady, 1884, fig. 8]

2005 Lamarckina scabra (Brady); Debenay et al., p. 336 pl. 3 , figs. 24,25

Remarks: The wall is aragonitic and finely perforate. The test is unequally biconvex. The spiral side is much flattened, and the umbilical side is distinctly convex. Chambers rapidly increasing in size as added. In the adult stage, the final chamber on the umbilical side covers the half of the test. The peripheral margin in carinate. Sutures are depressed. The aperture is interiomarginal-umbilical. The test surface is smooth.

Family EPISTOMINIDEA Wedekind, 1937

Subfamily EPISTOMININIAE Wedekind, 1937

Genus HOEGLUNDINA Brotzen, 1948

Hoeglundina elegans (d'Orbigny, 1826)

Figure 19.15-16

1826 Rotalia elegans d'Orbigny: p. 272, no. 6

1884 Pulvinulina elegans (d'Orbigny); Brady, $p$. 699, pl. 105, figs. 3-6

1931 Epistomina elegans (d'Orbigny); Cushman, p. 65 , pl. 13 , fig. 6

1979 Hoeglundina elegans (d'Orbigny); Corliss, p. 12 , pl. 5 , figs. $11-13$

1985 Hoeglundina elegans (d'Orbigny); Hermelin and Scott, p. 210, pl. 6, figs. 6, 7

1991 Hoeglundina elegans (d'Orbigny); Cimerman and Langer, p. 56, pl. 59, figs. 10-12

1992 Hoeglundina elegans (d'Orbigny); Schiebel, p. 49, pl. 5, fig. 8

1993 Hoeglundina elegans (d'Orbigny); Sgarrella and Moncharmont Zei, p. 242, pl. 26, figs. 7,8

1994 Hoeglundina elegans (d'Orbigny); Jones, p. 104 , pl. 105, figs. 3-6 [cop. Brady, 1884, figs. 3-6]

2005 Hoeglundina elegans (d'Orbigny); Rasmussen, p. 78 , pl. 9 , fig. 11

2008 Hoeglundina elegans (d'Orbigny); AbuZied et al., p. 51, pl. 1, figs. 23, 24

Remarks: The wall is aragonitic. The test is trochospirally enrolled and unequally biconvex, with a lesser convex spiral side and a higher convex 
umbilical side. The test is subcircular in outline. Backward curved sutures are visible on the spiral side. The periphery is carinate and keeled. The primary aperture is slit-like and parallel to the peripheral keel. A second interiomarginal, extraumbilical aperture is present on the umbilical side. The test surface is smooth.

Family ROBERTINIDAE Reuss, 1850

Subfamily ALLIATININAE McGowran, 1966

Genus ROBERTINA d'Orbigny, 1846

Robertina translucens Cushman and Parker, 1936

Figure 19.17-18

1936 Robertina translucens Cushman and Parker: p. 99, pl. 16, fig. 8a, b

1958 Robertina translucens Cushman and Parker; Parker, p. 263, pl. 2, fig. 34

1991 Robertiniodes translucens (Cushman and Parker); Rasmussen, p. 364, fig. 7, no. 4

2004 Robertina translucens Cushman and Parker; Chendes et al., p. 76, pl. 1, fig. 17

2005 Robertina translucens Cushman and Parker; Rasmussen, p. 79, pl. 9, fig. 12

Remarks: The wall is aragonitic and translucent. The test is high trochospirally coiled. Chambers increasing in size as added and are broad and inflated. Sutures are oblique and depressed. The aperture consists of two elongate slits, one reaching from the base of the final chamber into the septal face, and the other is parallel with the partition of the final chamber. An additional opening is present at the junction of the inner partition on the spiral side. The test surface is smooth.

Suborder ROTALIINA Delage and Herouard, 1896

Family BOLIVINIDAE Glaessner, 1937

Genus BOLIVINA d'Orbigny, 1839

Bolivina cistina Cushman, 1936

Figure 19.19-20

1936 Bolivina cistina Cushman: p. 55, pl. 8, fig. 4

1990 Bolivina cistina (Cushman); Hasegawa et al., p. 476 , pl. 3, figs. 1, 2

Remarks: The wall is calcareous, hyaline and perforate, more densely on the later chambers. The test is triangular in lateral view and compressed in peripheral view. Chambers are biserially arranged and are low and broad, rapidly increasing in size as added. The periphery is truncate. The aperture is loop-like, at the base of the apertural face, and provided with a toothplate. Pores are surrounded by small ridges in the apertural region. The test surface is ornamented with irregular ridges.
Bolivina plicatella Cushman, 1930b

Figure 19.21

1930b Bolivina plicatella Cushman: p. 46, pl. 18, fig. 10a, b

1931 Bolivina plicatella Cushman; Cushman and Parker, p. 15, pl. 3, fig. 19

1965 Bolivina plicatella plicatella Cushman; Souaya, p. 323 , pl. 2, fig. 22

1990 Bolivina plicatella Cushman; Hasegawa et al., p. 476, pl. 3, figs. 3, 4

1993 Bolivina plicatella plicatella Cushman; Mehrnusch, p. 11, figs. 22-27

Remarks: The wall is calcareous, hyaline and densely perforate. The test is subtriangular-elongate in lateral view. Chambers are biserially arranged, low and broad, and increasing in size as added. The periphery is subrounded. Sutures are depressed. The aperture is loop-like, at the base of the apertural face, and provided with a toothplate. The test surface is ornamented with sinuate ridges, covering the entire test and small irregular ridges in the apertural region.

Bolivina pseudoplicata Heron-Allen and Earland, $1930 \mathrm{a}$

Figure 19.22-23

1930a Bolivina pseudoplicata Heron-Allen and Earland: pp. 81-82, pl. 3, figs. $36-40$

1958 Bolivina pseudoplicata Heron-Allen and Earland; Parker, p. 261, pl. 2, fig. 8

1960 Bolivina pseudoplicata Heron-Allen and Earland; Hofker, p. 251, pl. D, fig. 108

1990 Bolivina pseudoplicata Heron-Allen and Earland; Hasegawa et al., p. 476, pl. 3, figs. 5,6

1991 Bolivina pseudoplicata Heron-Allen and Earland; Cimerman and Langer, p. 58, pl. 61, figs. 1, 2

1991 Bolivina pseudoplicata Heron-Allen and Earland; Rasmussen, p. 363, fig. 6, no. 11

1993 Bolivina pseudoplicata Heron-Allen and Earland; Sgarrella and Moncharmont Zei, p. 208 , pl. 14, figs. 9,10

2003 Bolivina pseudoplicata Heron-Allen and Earland; Murray, p. 19, fig. 5, no. 17

2005 Bolivina pseudoplicata Heron-Allen and Earland; Rasmussen, p. 80, pl. 9, figs. 16, 17

Remarks: The wall is calcareous, hyaline and perforate. The test is triangular-elongate in lateral view 
and wedge-shaped in peripheral view. Chambers are biserially arranged, low and broad, and increasing in size as added. Sutures are depressed. The periphery is subrounded. The aperture is loop-like, at the base of the apertural face, and provided with a toothplate. The test surface is ornamented with polygonal rips and sinuate ridges, covering the entire test and small irregular ridges are present in the apertural region.

Bolivina subspinescens Cushman, 1922a Figure 19.24

1922a Bolivina subspinescens Cushman: p. 48, pl. 7, fig. 5

1985 Bolivina subspinescens Cushman; Hermelin and Scott, p. 204, pl. 3, fig. 2

1990 Bolivina subspinescens Cushman; Hasegawa et al., p. 476, pl. 3, fig. 10

1992 Bolivina subspinescens Cushman; Schiebel, p. 34, pl. 1, fig. 5

1993 Bolivina subspinescens Cushman; Sgarrella and Moncharmont Zei, p. 210, pl. 14, figs. 12,13

2005 Bolivina subspinescens Cushman; Debenay et al., p. 336 pl. 3, fig. 9

2005 Sagrina subspinescens (Cushman); Rasmussen, p. 85 , pl. 11 , fig. 2

2008 Bolivina subspinescens Cushman; Leiter, p. 24 , pl. 3 , fig. 4

Remarks: The wall is calcareous, hyaline and perforate at the base of the later chambers. The test is elongate in lateral view. Chambers are biserially arranged, increasing in size as added, and are low and inflated. Chambers are slightly coiled along the vertical axis. The periphery is subrounded. Sutures are depressed. The aperture is ovate and bordered by a lip. Some fine pseudospines may be present at the base of the later chambers.

Bolivina variabilis (Williamson, 1858)

Figure 19.25-26

1858 Textularia variabilis Williamson: p. 76, pl. 6, figs. 162, 163

1965 Bolivina variabilis (Williamson); Phleger, p. 51, pl. 1, fig. 8

1991 Bolivina variabilis (Williamson); Cimerman and Langer, p. 59, pl. 61, figs. 7, 8

1992 Bolivina variabilis (Williamson); Schiebel, p. 32, pl. 1, fig. 6a
1993 Bolivina variabilis (Williamson); Hottinger, Halicz and Reiss, p. 91, pl. 110, figs. 1-4; pl. 111, figs. 1,2

2005 Bolivina variabilis (Williamson); Debenay et al., p. 336 pl. 3, fig. 4

Remarks: The wall is calcareous, hyaline and densely perforate. The test is triangular to elongate in lateral view. Chambers are biserially arranged, low and broad, increasing in size as added. The periphery is rounded. Sutures are depressed. The aperture is a loop-like opening and provided with a toothplate. Pores are surrounded by small polygonally ridges.

Bolivina sp. 1

Figure 19.27

Remarks: The wall is calcareous, hyaline and less densely perforate. The test is triangular in lateral view. Chambers are biserially arranged, broad and low, increasing in size as added. The periphery is subrounded. The aperture is a narrow loop at the base of the apertural face. The test surface is ornamented with flat irregular rips and ridges.

Genus BRIZALINA Costa, 1856

Brizalina difformis (Williamson, 1858)

Figure 19.28-29

1858 Textularia variablis var. difformis Williamson: p. 77 , pl. 6 , figs. 166,167

1958 Bolivina difformis (Williamson); Parker, p. 260, pl. 2, fig. 9

1991 Brizalina difformis (Williamson); Cimerman and Langer, p. 59, pl. 61, figs. 9-11

2003 Brizalina difformis (Williamson); Murray, p. 19, fig. 6 , no. 2

2009 Brizalina difformis (Williamson); Milker et al., p. 216, pl. 2, fig. 11

Remarks: The wall is calcareous, hyaline and less densely perforate. The test is triangular in lateral view and compressed in peripheral view. Chambers are biserially arranged and have short marginal spines. The periphery is subacute. The aperture is an elongate loop-like opening, partly bordered by a lip and provided with a toothplate. The test surface is irregularly pseudo-ornamented.

$$
\text { Brizalina dilatata (Reuss, 1850) }
$$

Figure 19.30

1850 Bolivina dilatata Reuss: p. 17, pl. 3, fig. 15

1911 Bolivina dilatata Reuss; Cushman, p. 33, text-fig. 54 
1991 Brizalina dilatata (Reuss); Cimerman and Langer, p. 59, pl. 62, fig. 2

1992 Bolivina dilatata Reuss; Schiebel, p. 31, pl. 1, fig. 4a

2002 Brizalina dilatata (Reuss); Kaminski et al., p. 173 , pl. 2, fig. 13

2004 Bolivina dilatata Reuss; Mendes et al., p. 180 , pl. 2, fig. 1

2008 Bolivina dilatata Reuss; Leiter, p. 22, pl. 3, fig. 6

Remarks: The wall is calcareous, hyaline and densely perforate. The test is subtriangular in lateral view and compressed in peripheral view. Chambers are biserially arranged. Sutures are slightly depressed and oblique. The periphery is subacute. The aperture is an elongate loop-like opening, partly bordered by a lip and provided with a toothplate. The test surface is smooth.

Brizalina spathulata (Williamson, 1858)

$$
\text { Figure 20.1-2 }
$$

1858 Textularia variablis var. spathulata Williamson: p. 76, pl. 6, figs. 164, 165

1884 Bolivina dilatata Reuss; Brady, p. 418, pl. 52, figs. 20, 21

1987 Bolivina spathulata (Williamson); Jorissen, p. 34 , pl. 1 , fig. 5

1991 Brizalina spathulata (Williamson); Cimerman and Langer, p. 60, pl. 62, figs. 3-5

1993 Bolivina spathulata (Williamson); Sgarrella and Moncharmont Zei, p. 210, pl. 14, fig. 3

1994 Brizalina spathulata (Williamson); Jones, p. 57, pl. 52, figs. 20, 21 [cop. Brady, 1884, figs. 20, 21]

2003 Brizalina spathulata (Williamson); Murray, p. 19 , fig. 6 , no. 3

2004 Brizalina spathulata (Williamson); Chendes et al., p. 76, pl. 2, fig. 3

2004 Brizalina spathulata (Williamson); Mendes et al., p. 180, pl. 2, fig. 7

2005 Brizalina spathulata (Williamson); Rasmussen, p. 81 , pl. 9 , fig. 23

2006 Brizalina spathulata (Williamson); Avsar et al., p. 133, pl. 1, fig. 19

2008 Brizalina spathulata (Williamson); AbuZied et al., p. 51, pl. 1, fig. 29

2009 Brizalina spathulata (Williamson); Milker et al., p. 216 , pl. 2, fig. 13
Remarks: The wall is calcareous and hyaline with dense perforation on the outer chamber margins on the outer chamber margins and near the sutures. The test is elongate-lanceolate in lateral view and compressed in peripheral view. Chambers are biserially arranged, increasing in size as added. The periphery is acute. Sutures are depressed and oblique. The aperture is an elongate loop-like opening, partly bordered by a lip and provided with a toothplate.

Brizalina striatula (Cushman, 1922c)

Figure 20.3

1922c Bolivina striatula Cushman: p. 27, pl. 3, fig. 10

1960 Bolivina striatula Cushman; Hofker, p. 251, pl. D, fig. 106

1965 Bolivina striatula Cushman; Phleger, p. 51, pl. 1, fig. 4

1991 Brizalina striatula (Cushman); Cimerman and Langer, p. 60, pl. 62, figs. 6-9

1992 Bolivina striatula Cushman; Schiebel, p. 32, pl. 1, fig. 9

1993 Brizalina striatula (Cushman); Hottinger, Halicz and Reiss, p. 92, pl. 112, figs. 3-8

1993 Bolivina striatula Cushman; Sgarrella and Moncharmont Zei, p. 210, pl. 14, fig. 16

2002 Brizalina striatula (Cushman); Kaminski et al., p. 172, pl. 2, fig. 10

2004 Bolivina striatula Cushman; Fiorini, p. 50, pl. 1, fig. 12

2005 Bolivina striatula Cushman; Debenay et al., p. 336 pl. 3, fig. 3

2005 Brizalina striatula (Cushman); Rasmussen, p. 82 , pl. 9 , fig. 24

2008 Brizalina striatula (Cushman); Abu-Zied et al., p. 51, pl. 1, fig. 30

2009 Brizalina striatula (Cushman); Milker et al. p. 216 , pl. 2, fig. 12

Remarks: The wall is calcareous, hyaline and densely perforate. The test is very elongate and lanceolate in lateral view and compressed in peripheral view. Chambers are biserially arranged, increasing in size as added. The periphery is acute. Sutures are depressed and oblique. The aperture is an elongate loop-like opening, partly bordered by a lip and provided with a toothplate. The test surface is ornamented with longitudinal costae at the basal and middle part of the test. 


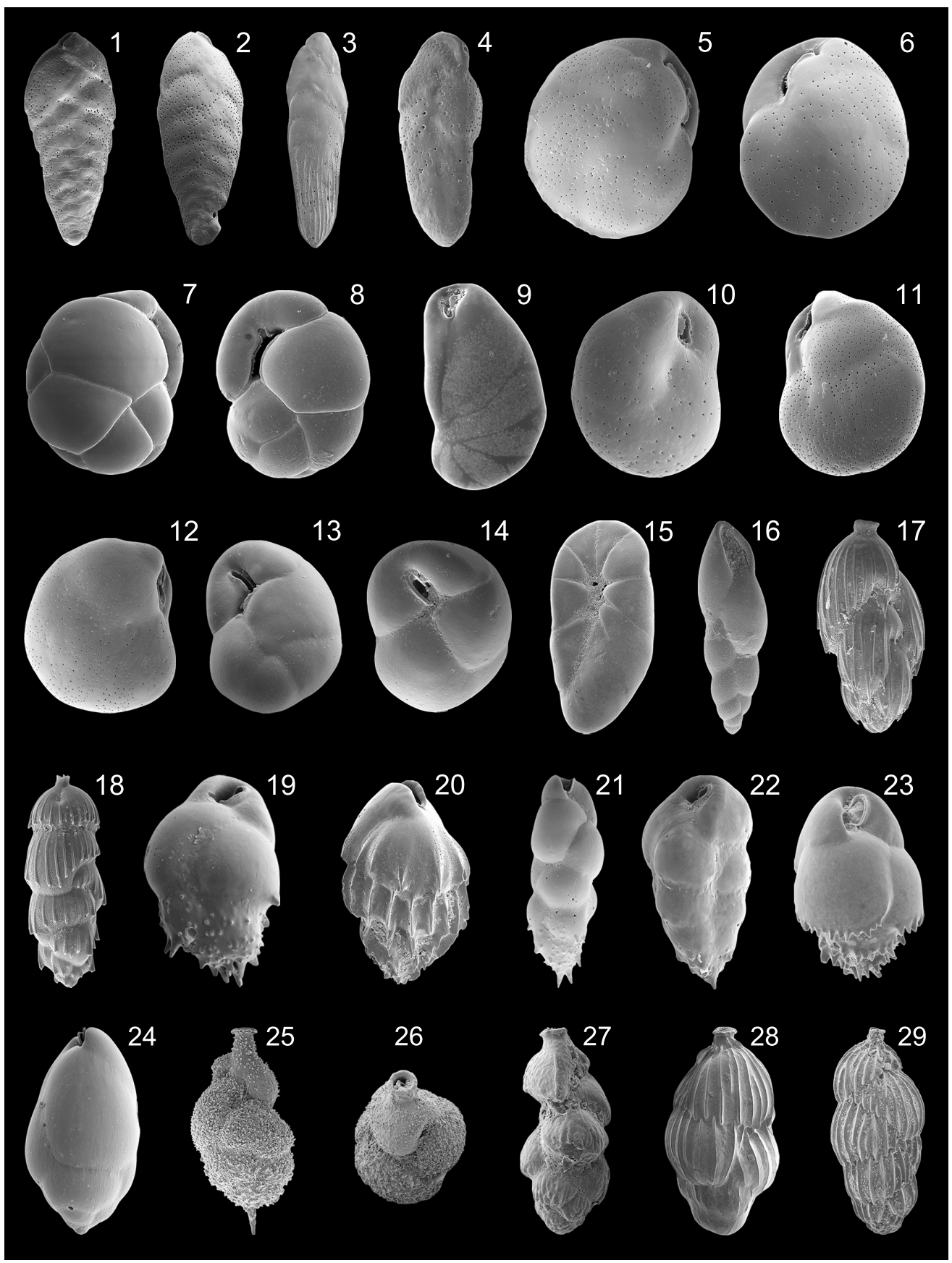

FIGURE 20. 1 Brizalina spathulata (Williamson), 599x, lateral view; 2 B. spathulata (Williamson), 572x, lateral view; 3 Brizalina striatula (Cushman), 429x, lateral view; 4 Brizalina sp. 1, 695x, lateral view; 5 Cassidulina carinata Silvestri, 655x, apertural side; 6 C. laevigata s.s. d'Orbigny, 1050x, apertural side; 7 Cassidulina obtusa Williamson, 829x, apertural side; 8 C. obtusa Williamson, 930x, apertural side; 9 Cassidulinoides bradyi (Norman), 864x, lateral view; 10 Globocassidulina oblonga (Reuss), 1220x, apertural side; 11 G. oblonga (Reuss), 650x, apertural side; 12 G. oblonga (Reuss), 771x, apertural side; 13 Globocassidulina subglobosa (Brady), 1010x, apertural side; 14 G. subglobosa (Brady), 1150x, apertural side; 15 Floresina sp. 1, 770x, apertural side; 16 Stainforthia complanata (Egger), 735x, lateral view; 17 Rectuvigerina bononiensis (Fornasini), 854x, lateral view; 18 Rectuvigerina phlegeri Le Calvez, 686x, lateral view; 19 Bulimina aculeata d'Orbigny, 427x, lateral view; 20 Bulimina costata d'Orbigny, 771x, lateral view; 21 Bulimina elongata d'Orbigny, 407x, lateral view; 22 Bulimina gibba Fornasini, 509x, lateral view; 23 Bulimina marginata d'Orbigny, 766x, lateral view; 24 Globobulimina affinis (d'Orbigny), 355x, lateral view; 25 Neouvigerina ampullacea (Brady), 644x, lateral view; 26 N. ampullacea (Brady), 642x, apertural view; 27 Siphouvigerina? sp. 1, 576x, lateral view; 28 Uvigerina mediterranea Hofker, 321x, lateral view; 29 Uvigerina peregrina Cushman, 385x, lateral view. 


\section{Brizalina sp. 1}

Figure 20.4

Remarks: The wall is calcareous and hyaline, with a densely and coarsely perforation of the later chambers. The test is lanceolate and elongate in lateral view and compressed in peripheral view. The chambers are biserially arranged and broad, increasing in size as added. The final chamber has an irregular form. The aperture is an elongate looplike opening, provided with an internal toothplate.

Family CASSIDULINIDAE d'Orbigny, 1839

Subfamily CASSIDULININAE d'Orbigny, 1839

$$
\text { Cassidulinid sp. } 1
$$

Remarks: The wall is calcareous and finely perforate. The test is circular and flattened. Early chambers are biserially enrolled and later chambers are uniserially enrolled. Chambers increasing in size as added. The aperture, at the base of the final chamber, is rounded. The test surface is smooth.

Genus CASSIDULINA d'Orbigny, 1826

Cassidulina laevigata s.I. d'Orbigny, 1826

Figure 20.5-6

1826 Cassidulina laevigata d'Orbigny: p. 282, pl. 15, figs. 4,5

1896 Cassidulina laevigata d'Orbigny var. carinata Silvestri: p. 104, pl. 2, fig. 10a-c (fide Ellis and Messina 1940ff)

1911 Cassidulina laevigata d'Orbigny; Cushman, p. 96, text; fig. 150

1960 Cassidulina laevigata d'Orbigny; Hofker, p. 250, pl. D, fig. 103

1965 Cassidulina carinata Silvestri; Todd, p. 40, pl. 17, fig. 4

1988 Cassidulina laevigata d'Orbigny; Loeblich and Tappan, pp. 144-145, pl. 555, figs. 1, 5

1990 Cassidulina carinata Silvestri; Hasegawa et al., p. 477, pl. 4, figs. 1, 2

1991 Cassidulina laevigata d'Orbigny; Cimerman and Langer, p. 61, pl. 63, figs. 1, 3

1991 Cassidulina carinata Silvestri; Rasmussen, p. 364 , fig. 7 , no. 1

1992 Cassidulina laevigata d'Orbigny; Schiebel, p. 39, pl. 2, fig. 11

1993 Cassidulina carinata Silvestri; Sgarrella and Moncharmont Zei, p. 236, pl. 23, figs. 8, 9

2004 Cassidulina carinata Silvestri; Chendes et al., p. 76 , pl. 2, fig. 4
2004 Cassidulina laevigata d'Orbigny; Mendes et al., p. 180, pl. 2, fig. 11

2005 Cassidulina carinata Silvestri; Rasmussen, p. 82 , pl. 10 , fig. 1

2006 Cassidulina carinata Silvestri; Avsar et al., p. 133 , pl. 1, fig. 20

2008 Cassidulina carinata Silvestri ; Abu-Zied et al., p. 52, pl. 2, figs. 1, 2

2009 Cassidulina carinata Silvestri; Frezza and Carboni, p. 57, pl. 2, fig. 12

2009 Cassidulina laevigata d'Orbigny; Milker et al., p. 216, pl. 2, fig. 15

Remarks: The wall is calcareous, densely and finely perforate. The test is lenticular in lateral view and flattened with a carinate periphery. Chambers are biserially arranged and planispirally enrolled. Sutures are depressed on one side and flush with the surface on the other side. The aperture is an elongate and narrow slit, provided with a toothplate. The test has a smooth surface. The species Cassidulina laevigata d'Orbigny and Cassidulina carinata Silvestri have been summarized to Cassidulina laevigata s.I. Cassidulina carinata is characterized by having an acute and carinate periphery and a thin keel.

Cassidulina obtusa Williamson, 1858 Figure 20.7-8

1858 Cassidulina obtusa Williamson: p. 69, pl. 6, figs. 143, 144

1884 Cassidulina crassa d'Orbigny, Brady, p. 429 , pl. 54, figs. 4,5

1911 Cassidulina crassa d'Orbigny; Cushman, p. 97 , text-fig. 151

1945 Cassidulina crassa d'Orbigny; Cushman, p. 288 , figs. 18,19

1958 Cassidulina crassa d'Orbigny; Parker, p. 271, pl. 4, fig. 12

1987 Cassidulina crassa d'Orbigny; Jorissen, p. 41 , pl. 1 , fig. 3

1991 Cassidulina crassa d'Orbigny; Rasmussen, p. 364, fig. 7 , no. 2

1994 Cassidulina crassa d'Orbigny; Jones, p. 60 , pl. 54, figs. 4, 5 [cop. Brady 1884, figs. $4,5]$

2003 Cassidulina obtusa Williamson; Murray, p. 21, fig. 6, no. 11,12

2005 Cassidulina obtusa Williamson; Rasmussen, p. 82 , pl. 10 , figs. 2-4 
2008 Cassidulina crassa d'Orbigny; Abu-Zied et al., p. 52, pl. 2, figs. 3,4

2009 Cassidulina crassa d'Orbigny; Milker et al., p. 216 , pl. 2, fig. 17

Remarks: The wall is calcareous, finely and densely perforate. The test is ovate with a broadly rounded periphery. Chambers are biserially arranged, planispirally enrolled and inflated. Sutures are depressed. The aperture is a long and narrow slit, parallel to the periphery and provided with a long, slender tooth. A second small perpendicular slit extending between the aperture and the peripheral margin. The test has a smooth surface.

Genus CASSIDULINOIDES Cushman, 1927

Cassidulinoides bradyi (Norman, in Brady 1881)

Figure 20.9

1881 Cassidulina bradyi Norman: type reference Brady, 1881, p. 59

1884 Cassidulina bradyi Norman; Brady, p. 431, pl. 54, figs. 6-9

1993 Cassidulinoides bradyi (Norman); Sgarrella and Moncharmont Zei, p. 211, pl. 14, fig. 15

1994 Cassidulinoides bradyi (Norman); Jones, p. 60 , pl. 54, figs. 6-9 [cop. Brady, 1884, figs. 6-9]

2005 Cassidulinoides bradyi (Norman); Rasmussen, p. 83, pl. 10, fig. 8

2008 Cassidulinoides bradyi (Norman); AbuZied et al., p. 52, pl. 2, figs. 5, 6

2009 Cassidulinoides bradyi (Norman); Milker et al., p. 216, pl. 2, fig. 18

Remarks: The wall is calcareous, densely and finely perforate. The test is elongate with a rounded periphery. Earlier chambers are biserially arranged and planispirally enrolled, later chambers are uncoiled. Sutures are slightly depressed. The terminal aperture is ovate and provided with a toothplate.

Genus GLOBOCASSIDULINA Voloshinova, 1960 Globocassidulina oblonga (Reuss, 1850)

Figure 20.10-12

1850 Cassidulina oblonga Reuss: p. 12, pl. 3, figs. 5, 6

1987 Globocassidulina oblonga (Reuss); Alberola et al., p. 308, pl. 4, fig. 12

1987 Cassidulina oblonga Reuss; Jorissen, p. 41, pl. 3, fig. 11
1988 Globocassidulina oblonga (Reuss); Loeblich and Tappan, p. 145, pl. 557, figs. 1-4

1990 Globocassidulina subglobosa (Brady); Hasegawa et al., p. 477, pl. 4, figs. 5, 6

2005 Globocassidulina oblonga (Reuss); Rasmussen, p. 83, pl. 10, figs. 9, 10

2006 Globocassidulina subglobosa (Brady); Avsar et al., p. 133, pl. 2, figs. 1, 2

2009 Globocassidulina subglobosa (Brady); Frezza and Carboni, p. 57, pl. 2, fig. 13

2009 Cassidulina oblonga Reuss; Milker et al., p. 216 , pl. 2, fig. 14

Remarks: The wall is calcareous and densely perforate. The test is globular and ovate, with a broadly rounded periphery. Chambers are biserially arranged and planispirally enrolled. Sutures are oblique and flush with the surface. The aperture is elongate, partly bordered by a lip and provided with a toothplate. The test surface is a smooth.

Globocassidulina subglobosa (Brady, 1881)

Figure 20.13-14

1881 Cassidulina subglobosa Brady: p. 60

1884 Cassidulina subglobosa Brady; Brady, p. 430, pl. 54, fig. 17

1911 Cassidulina subglobosa Brady; Cushman, p. 98 , text-fig. 152

1958 Globocassidulina subglobosa (Brady); Parker, p. 272, pl. 4, fig. 13

1979 Globocassidulina subglobosa (Brady); Corliss, p. 8, pl. 3, figs. 12, 13

1988 Globocassidulina subglobosa (Brady); Loeblich and Tappan, p. 145, pl. 557, figs. 18-23 [figs. 21-23: cop. Brady, 1884, fig. 17]

1990 Globocassidulina oblonga (Reuss); Hasegawa et al., p. 477, pl. 4, figs. 3, 4

1991 Globocassidulina subglobosa (Brady); Cimerman and Langer, p. 61, pl. 63, figs. 4-6

1991 Globocassidulina subglobosa (Brady); Rasmussen, p. 364, fig. 7, no. 3

1992 Globocassidulina subglobosa (Brady); Schiebel, p. 47, pl. 2, fig. 14

1993 Globocassidulina subglobosa (Brady); Sgarrella and Moncharmont Zei, p. 236, pl. 24, figs. 1,2 
1994 Globocassidulina subglobosa (Brady); Jones, p. 60, pl. 54, fig. 17 [cop. Brady, 1884, fig. 17]

2003 Globocassidulina subglobosa (Brady); Murray, p. 24, fig. 8, no. 7

2005 Globocassidulina subglobosa (Brady); Rasmussen, p. 84, pl. 10, fig. 11

2009 Globocassidulina subglobosa (Brady); Milker et al., p. 216, pl. 2, fig. 16

Remarks: The wall is calcareous, and densely and finely perforate. The test is globular and ovate with a rounded periphery. Chambers are biserially arranged and planispirally enrolled. Sutures are oblique and depressed. The aperture is subelliptical, bordered by a lip and provided with a toothplate. The test surface is smooth.

Family TURRILINIDAE Cushman, 1927 Genus FLORESINA Revets, 1990

\section{Floresina sp. 1}

Figure 20.15

1991 Floresina sp. 1; Cimerman and Langer, p. 61 , pl. 65, figs. 4-6

1993 Floresina sp. A; Hottinger, Halicz and Reiss, p. 95, pl. 117, figs. 8-11

Remarks: The wall is calcareous, densely and finely perforate. The test is elongate, with trochospirally arranged chambers. Sutures are oblique and flush with the test surface. The aperture is a rounded opening in the center of the apertural face and provided with a small toothplate. Radial grooves extending from the center of the apertural face to the periphery. The test surface is smooth.

Family STAINFORTHIIDAE Reiss, 1963 Genus STAINFORTHIA Hofker, 1956

Stainforthia complanata (Egger, 1893)

Figure 20.16

1893 Virgulina schreibersiana Czjzek var. complanata Egger: pp. 292-293, pl. 8, figs. 91, 92

1951 Virgulina complanata Egger; Phleger and Parker, p. 19, pl. 9, figs. 1-3

1958 Virgulina complanata Egger; Parker, p. 272, pl. 4, fig. 20

1993 Stainforthia complanata (Egger); Sgarrella and Moncharmont Zei, p. 214, pl. 15, fig. 4

2005 Stainforthia complanata (Egger); Rasmussen, p. 84 , pl. 10, figs. 16,17

Remarks: The wall is calcareous, hyaline and finely and densely perforate. The test is very elon- gate. Chambers are inflated and ovate, increasing in size as added. Earlier chambers are triserially arranged. Later chambers are biserially arranged with more loosely biserial arranged final chambers, leading to slightly twisted chambers along a vertical axis. Sutures are oblique and depressed. The aperture is a terminal and ovate opening, partly bordered by a lip and provided with a toothplate. The test surface is smooth.

Family SIPHOGENERINOIDIDAE Saidova, 1981

Subfamily TUBULOGENERININAE Saidova, 1981

Genus RECTUVIGERINA Mathews, 1945

Rectuvigerina bononiensis (Fornasini, 1888)

Figure 20.17

1888 Uvigerina bononiensis Fornasini: p. 48, pl. 3 , fig. 12

1898 Uvigerina bononiensis Fornasini; Fornasini, p. 27-28, pl. 1, figs. 1-8

1953 Uvigerina bononiensis bononiensis Fornasini; Papp, p. 305, pl. 1, figs. 17-20

1992 Rectuvigerina bononiensis (Fornasini); Schiebel, p. 54, pl. 3, fig. 8

2005 Uvigerina bononiensis Fornasini; Rasmussen, p. 88 , pl. 11, figs. 10,11

2008 Uvigerina bononiensis Fornasini; Leiter, p. 55, pl. 4, fig. 10

2009 Rectuvigerina bononiensis (Fornasini);

Milker et al., p. 216, pl. 2, fig. 20

Remarks: The wall is calcareous and finely and densely perforate. The test is elongate in lateral view and rounded in apertural view. Early chambers are triserially arranged and later chambers are biserially arranged. Chambers are inflated. Sutures are oblique and depressed. The aperture is terminal and rounded, on a short neck, bordered by a lip and provided with an internal toothplate. Chambers are ornamented with longitudinal costae.

Rectuvigerina phlegeri Le Calvez, in Berthois and Le Calvez 1959

Figure 20.18

1959 Rectuvigerina phlegeri Le Calvez: type reference Berthois and Le Calvez, 1959, p. 363, pl. 1, fig. 11

1992 Rectuvigerina phlegeri Le Calvez; Schiebel, p. 55, pl. 3, fig. 10 
1993 Rectuvigerina phlegeri Le Calvez; Sgarrella and Moncharmont Zei, p. 215, pl. 16, figs. 3, 4

2004 Rectuvigerina phlegeri Le Calvez; Chendes et al. p. 76, pl. 2, fig. 5

2006 Rectuvigerina phlegeri Le Calvez; Avsar et al., p. 133, pl. 2, fig. 3

2008 Rectuvigerina phlegeri Le Calvez; AbuZied et al., p. 52, pl. 2, fig. 15

2009 Rectuvigerina phlegeri Le Calvez; Frezza and Carboni, p. 55, pl. 1, fig. 6

2009 Rectuvigerina phlegeri Le Calvez; Milker et al., p. 216, pl. 2, fig. 19

Remarks: The wall is calcareous and finely and densely perforate. The test is elongate in lateral view and rounded in apertural view. Early chambers are triserially, than biserially, and later chambers are uniserially arranged. Sutures are oblique in the early stage, horizontal in the later stage, and depressed. The aperture is terminal and rounded on a short neck, bordered by a lip and provided with an internal toothplate. Chambers are ornamented with longitudinal costae.

Family BULIMINIDAE Jones, in Griffith and Henfrey 1875

Genus BULIMINA d'Orbigny, 1826

Bulimina aculeata d'Orbigny, 1826

Figure 20.19

1826 Bulimina aculeata d'Orbigny: p. 269, no. 7

1884 Bulimina aculeata d'Orbigny; Brady, p. 406, pl. 51, figs. 7-9

1911 Bulimina aculeata d'Orbigny; Cushman, p. 86, text-fig. 139

1958 Bulimina aculeata d'Orbigny; Parker, p. 261, pl. 2, figs. 17,18

1985 Bulimina aculeata d'Orbigny; Hermelin and Scott, p. 204, pl. 3, fig. 7

1987 Bulimina marginata forma aculeata d'Orbigny; Jorissen, p. 43, pl. 4, fig. 5

1990 Bulimina aculeata d'Orbigny; Hasegawa et al., p. 476, pl. 3, figs. 14,15

1991 Bulimina aculeata d'Orbigny; Cimerman and Langer, p. 61, pl. 63, figs. 10, 11

1992 Bulimina aculeata d'Orbigny; Schiebel, p. 35, pl. 2, fig. 1

1993 Bulimina aculeata d'Orbigny; Sgarrella and Moncharmont Zei, p. 211, pl. 15, fig. 1
1994 Bulimina aculeata d'Orbigny; Jones, p. 56, pl. 51, figs. 7-9 [cop. Brady, 1884, figs. 7-9]

2002 Bulimina aculeata d'Orbigny; Kaminski et al., p. 174, pl. 3, fig. 3

2004 Bulimina aculeata d'Orbigny; Chendes et al., p. 76, pl. 2, fig. 8

2004 Bulimina aculeata d'Orbigny; Mendes et al., p. 180 , pl. 2, fig. 8

2008 Bulimina aculeata d'Orbigny; Abu-Zied et al., p. 52, pl. 2, fig. 7

2008 Bulimina aculeata d'Orbigny; Leiter, p. 24, pl. 3, fig. 11

2009 Bulimina aculeata d'Orbigny; Milker et al., p. 216 , pl. 2, fig. 21

Remarks: The wall is calcareous and finely perforate. The test is ovate in lateral view. Chambers are triserially arranged, inflated and slightly twisted along the vertical axis. Sutures are oblique and depressed. The aperture is loop-shaped on the face of the final chamber, bordered by an everted rim and provided with a toothplate. Earlier chambers have larger pseudospones, and later chambers have shorter pseudospines or pseudospines are absent on the later chambers. The test surface is smooth.

\section{Bulimina costata d'Orbigny, 1852}

Figure 20.20

1852 Bulimina costata d'Orbigny: p. 194

1958 Bulimina costata d'Orbigny; Parker, p. 261, pl. 2, figs. 19,20

1987 Bulimina costata d'Orbigny; Jorissen, p. 34, pl. 1, fig. 9

1991 Bulimina cf. alazaensis Cushman; Cimerman and Langer, p. 62, pl. 64, figs. 1, 2

1991 Bulimina costata d'Orbigny; Rasmussen, p. 363 , fig. 6 , no. 5

1993 Bulimina costata d'Orbigny; Sgarrella and Moncharmont Zei, p. 211, pl. 15, fig. 3

2002 Bulimina costata d'Orbigny; Kaminski et al., p. 174, pl. 3, figs. 5, 6

2004 Bulimina costata d'Orbigny; Chendes et al., p. 76, pl. 2, fig. 6

2005 Bulimina costata d'Orbigny; Rasmussen, p. 85 , pl. 11 , fig. 3

2008 Bulimina costata d'Orbigny; Abu-Zied et al., p. 52, pl. 2, figs. 8,9 
Remarks: The wall is calcareous and densely perforate. The test is ovate in lateral view. Early chambers are triserially arranged and later chambers tend to be uniserially arranged. Sutures are oblique and depressed. The aperture is loop-shaped on the face of the final chamber, bordered by an everted rim and provided with a toothplate. The test surface is ornamented with longitudinal ridges, resulting in short spines at the base of the test. The test surface is smooth.

\section{Bulimina elongata d'Orbigny, 1846} Figure 20.21

1846 Bulimina elongata d'Orbigny: p. 187, pl. 11, figs. 19, 20

1884 Bulimina elegans d'Orbigny; Brady, p. 398, pl. 50 , figs. 3,4

1884 Bulimina elongata d'Orbigny; Brady, p. 401, pl. 51, figs. 1,2

1901 Bulimina elongata d'Orbigny; Fornasini, p. 376, figs. 10, 20

1911 Bulimina elongata d'Orbigny; Cushman, $p$. 79, text-fig. 131

1991 Bulimina elongata d'Orbigny; Cimerman and Langer, p. 62, pl. 64, figs. 3-8

1993 Bulimina elongata d'Orbigny; Hottinger, Halicz and Reiss, p. 99, pl. 124, figs. 3-6

1993 Bulimina elongata d'Orbigny; Sgarrella and Moncharmont Zei, p. 211, pl. 15, figs. 10, 11

1994 Bulimina elongata d'Orbigny; Jones, p. 55, pl. 50, figs. 3, 4; pl. 51, figs. 1, 2 [cop. Brady, 1884, figs. 3, 4 and 1, 2]

2002 Bulimina elongata d'Orbigny; Kaminski et al., p. 175, pl. 3, fig. 4

2004 Bulimina elongata d'Orbigny; Chendes et al., p. 76, pl. 2, fig. 7

2009 Bulimina elongata d'Orbigny; Milker et al., p. 216 , pl. 2, fig. 22

Remarks: The wall is calcareous and finely perforate. The test is elongate in lateral view. Chambers are triserially arranged and inflated. Later chambers are more loosely coiled. Sutures are depressed and oblique. The aperture is loopshaped on the face of the final chamber, bordered by an everted rim, and provided with a toothplate. The test surface is smooth. Specimens often have short basal pseudospines, but differ from Bulimina aculeata by their more elongate test.
Bulimina gibba Fornasini, 1901

Figure 20.22

1884 Bulimina elegans d'Orbigny; Brady, p. 398, pl. 50 , figs. 1,2

1901 Bulimina gibba Fornasini: p. 378, figs. 32, 34

1958 Bulimina gibba Fornasini; Parker, p. 261, pl. 2, figs. 21, 22

1960 Bulimina gibba Fornasini; Hofker, p. 248, pl. D, figs. 91-95

1994 Bulimina gibba Fornasini; Jones, p. 54, pl. 50, figs. 1, 2 [cop. Brady, 1884, figs. 1, 2]

2005 Bulimina gibba Fornasini; Rasmussen, p. 86 , pl. 11, fig. 5

2005 Bulimina gibba Fornasini; Milker et al., p. 216, pl. 2, fig. 23

Remarks: The wall is calcareous and finely perforate. The test is elongate in lateral view. Chambers are triserially arranged and inflated. Sutures are oblique and depressed. The aperture is loopshaped on the face of the final chamber, surrounded by an everted rim and provided with a toothplate. Basal pseudospines are present. The test surface is smooth.

\section{Bulimina marginata d'Orbigny, 1826}

Figure 20.23

1826 Bulimina marginata d'Orbigny: p. 269, pl. 12 , figs. $10-12$

1911 Bulimina marginata d'Orbigny; Cushman, p. 83 , text-fig. 136

1958 Bulimina marginata d'Orbigny; Parker, p. 262, pl. 2, fig. 23

1987 Bulimina marginata forma marginata d'Orbigny; Jorissen, p. 43, pl. 4, fig. 6

1988 Bulimina marginata d'Orbigny; Loeblich and Tappan, p. 150 , pl. 571, figs. 1-3

1991 Bulimina marginata d'Orbigny; Cimerman and Langer, p. 62, pl. 64, figs. 9-11

1991 Bulimina marginata marginata d'Orbigny; Rasmussen, p. 363 , fig. 6 , no. 6

1992 Bulimina marginata d'Orbigny; Schiebel, $p$. 36, pl. 2, fig. 2

1993 Bulimina marginata d'Orbigny; Sgarrella and Moncharmont Zei, p. 212, pl. 15, figs. 5-7

1994 Bulimina marginata d'Orbigny; Jones, p. 55 , pl. 51, figs. 3-5 
2004 Bulimina marginata d'Orbigny; Mendes et al., p. 180 , pl. 2, fig. 3

2005 Bulimina marginata d'Orbigny; Rasmussen, p. 86 , pl. 11, fig. 6

2008 Bulimina marginata d'Orbigny; Abu-Zied et al., p. 52, pl. 2, fig. 11

2008 Bulimina marginata d'Orbigny; Leiter, p. 26, pl. 3, fig. 12

2009 Bulimina marginata d'Orbigny; Milker et al., p. 216 , pl. 2, fig. 24

Remarks: The wall is calcareous and finely perforate. The test is ovate in lateral view. Early chambers are triserially arranged and later chambers tend to a uniserial chamber arrangement. Chambers are inflated. The aperture is loop-shaped on the face of the final chamber, surrounded by an everted rim and provided with a toothplate. Basal pseudospines are present. The test surface is smooth.

Genus GLOBOBULIMINA Cushman, 1927

Globobulimina affinis (d'Orbigny, 1839a)

Figure 20.24

1839a Bulimina affinis d'Orbigny: p. 105, pl. 2, figs. 25,26

1993 Globobulimina affinis (d'Orbigny); Sgarrella and Moncharmont Zei, p. 212, pl. 15, figs. 8,9

2005 Globobulimina affinis (d'Orbigny); Rasmussen, p. 87, pl. 11, fig. 7

2006 Globobulimina affinis (d'Orbigny); Avsar et al., p. 133, pl. 2, fig. 6

2008 Globobulimina affinis (d'Orbigny); AbuZied et al., p. 52, pl. 2, figs. 13, 14

2008 Globobulimina affinis (d'Orbigny); Leiter, $p$. 40 , pl. 4 , fig. 4

2009 Globobulimina affinis (d'Orbigny); Milker et al., p. 218, pl. 3, fig. 1

Remarks: The wall is calcareous and finely and densely perforate. The test is ovate in lateral view and circular in apertural view. Chambers are triserially arranged and inflated, rapidly increasing in size as added and strongly overlapping each other. Sutures are oblique and slightly depressed. The aperture is loop-shaped and provided with a toothplate. The test surface is ornamented with fine longitudinal grooves.

Family UVIGERINIDAE Haeckel, 1894 Subfamily UVIGERININAE Haeckel, 1894 Genus NEOUVIGERINA Thalmann, 1952
Neouvigerina ampullacea (Brady, 1884)

Figure 20.25-26

1884 Uvigerina asperula Czjzek var. ampullacea Brady: p. 579, pl. 75, figs. 10, 11

1923 Uvigerina ampullacea Brady; Cushman, $p$. 162, pl. 42, figs. 5,6

1958 Uvigerina auberiana (d'Orbigny); Parker, $p$. 263, pl. 2, figs. 35-36

1985 Uvigerina auberiana (d'Orbigny); Hermelin and Scott, p. 218, pl. 3, fig. 8

1988 Neouvigerina ampullacea (Brady); Loeblich and Tappan, p. 151, pl. 573, figs. 1417 [figs. 14-16: cop. Brady, 1884, figs. 10, 11]

1993 Neouvigerina ampullacea (Brady); Hottinger, Halicz and Reiss, p. 101, pl. 126, figs. 8-11; pl. 127, figs. 1-3

1993 Uvigerina auberiana (d'Orbigny); Sgarrella and Moncharmont Zei, p. 214, pl. 15, fig. 13

1994 Siphouvigerina ampullacea (Brady); Jones, p. 86, pl. 75, figs. 10, 11 [cop. Brady, 1884, figs. 10, 11]

2005 Uvigerina auberiana (d'Orbigny); Rasmussen, p. 87 , pl. 11 , fig. 9

Remarks: The wall is calcareous. The test is elongate-ovate in lateral view. Early chambers are triserially, later chambers are biserially arranged and final chambers tend to have a uniserial chamber arrangement. Chambers are subglobular, increasing in size as added. The rounded aperture is on a short neck, bordered by an imperforate lip, and is provided with a spirally folded toothplate. The entire test is ornamented with short pseudospines. An apical pseudospine is present. We believe that species described and listed here as $U$. auberiana belong to Neouvigerina ampullacea.

\section{Genus SIPHOUVIGERINA Parr, 1950 Siphouvigerina? sp. 1 \\ Figure 20.27}

1991 cf. Siphouvigerina sp. 1; Cimerman and Langer, p. 62, pl. 66, figs. 1, 2

Remarks: The wall is calcareous and finely perforate. The test is elongate. Earlier chambers are triserially arranged and appressed. Later chambers are more loosely triserially, then biserially, arranged and umbrella-like. The rounded aperture is terminal, at the end of a short neck and bordered by a lip. The test surface is irregularly ornamented with longitudinal ridges. 
Genus UVIGERINA d'Orbigny, 1826

Uvigerina mediterranea Hofker, 1932

Figure 20.28

1884 Uvigerina pygmaea d'Orbigny; Brady, p. 575 , pl. 74 , figs. 11,12

1932 Uvigerina mediterranea Hofker: pp. 118121, fig. 32

1958 Uvigerina mediterranea Hofker; Parker, p. 263, pl. 2, figs. $39-40$

1960 Eouvigerina mediterranea (Hofker); Hofker, p. 251, pl. D, fig. 107

1987 Uvigerina mediterranea Hofker; Jorissen, p. 214 , pl. 1, fig. 2

1991 Uvigerina mediterranea Hofker; Cimerman and Langer, p. 63, pl. 65, figs. 7-9

1993 Uvigerina mediterranea Hofker; Sgarrella and Moncharmont Zei, p. 214, pl. 16, figs. $1-2$

1994 Uvigerina mediterranea Hofker; Jones, p. 86 , pl. 74, figs. 11, 12 [cop. Brady, 1884, figs. 11, 12]

2008 Uvigerina mediterranea Hofker; Abu-Zied et al., p. 52, pl. 2, figs. 17, 18

2009 Uvigerina peregrina Cushman; Milker et al., p. 218 , pl. 3 , fig. 3

Remarks: The wall is calcareous, finely and densely perforate. The test is elongate-ovate. Chambers are triserially arranged and inflated, increasing in size as added. Sutures are distinct, depressed and oblique. The aperture is terminal, on a short neck and provided with a toothplate. The test surface is ornamented with longitudinal costae, extending from the sutures to the base of the chambers.

Uvigerina peregrina Cushman, 1923

Figure 20.29

1923 Uvigerina peregrina Cushman: p. 166, pl. 42, figs. $7-10$

1958 Uvigerina peregrina Cushman; Parker, $p$. 263, pl. 2, figs. 37,38

1985 Uvigerina peregrina Cushman; Hermelin and Scott, p. 218, pl. 3, fig. 10

1988 Uvigerina peregrina Cushman; Loeblich and Tappan, p. 151 , pl. 573, figs. 24-28 [figs. 24-27: cop. Cushman, figs. 7-10]

1991 Uvigerina peregrina Cushman; Rasmussen, p. 363 , fig. 6 , no. 9
1993 Uvigerina peregrina Cushman; Sgarrella and Moncharmont Zei, p. 215, pl. 16, fig. 5

2004 Uvigerina peregrina Cushman; Mendes et al., p. 180, pl. 2, fig. 12

2005 Uvigerina peregrina Cushman; Rasmussen, p. 88 , pl. 11, figs. 14,15

2008 Uvigerina peregrina Cushman; Abu-Zied et al., p. 52, pl. 2, figs. 19, 20

2009 Uvigerina peregrina Cushman; Frezza and Carboni, p. 57, pl. 2, fig. 15

Remarks: The wall is calcareous and finely perforate. The test is elongate-subovate. Chambers are triserially arranged and inflated. Sutures are distinct and depressed. The aperture is terminal, on a short neck and provided with a toothplate. The test surface is ornamented with longitudinal costae, extending from the sutures to the base of the chambers, and with pustules.

\section{Uvigerina sp. 1 \\ Figure 21.1}

Remarks: The wall is calcareous and coarsely perforate. The test is ovate in outline and rounded in apertural view. Early chambers are appressed and triserially arranged. Later chambers are more loosely triserially arranged and inflated. Sutures are distinct and depressed. The aperture is terminal, bordered by a lip and provided with a toothplate. The test surface is partly ornamented with longitudinally ridges.

Subfamily ANGULOGERININAE Galloway, 1933 Genus ANGULOGERINA Cushman, 1927 Angulogerina angulosa (Williamson, 1858)

Figure 21.2-4

1858 Uvigerina angulosa Williamson: p. 67, pl. 5, fig. 140

1923 Uvigerina angulosa Williamson; Cushman, p. 170 , pl. 41 , figs. $17-20$

1958 Angulogerina angulosa (Williamson); Parker, p. 259, pl. 2, figs. 1, 2

1988 Angulogerina angulosa (Williamson); Loeblich and Tappan, p. 151, pl. 574, figs. 5-9

1991 Angulogerina angulosa (Williamson); Cimerman and Langer, p. 63, pl. 66, figs. 3,4

1992 Trifarina angulosa (Williamson); Schiebel, p. 56 , pl. 3 , fig. 1

1993 Angulogerina angulosa (Williamson); Sgarrella and Moncharmont Zei, p. 215, pl. 16, fig. 8 


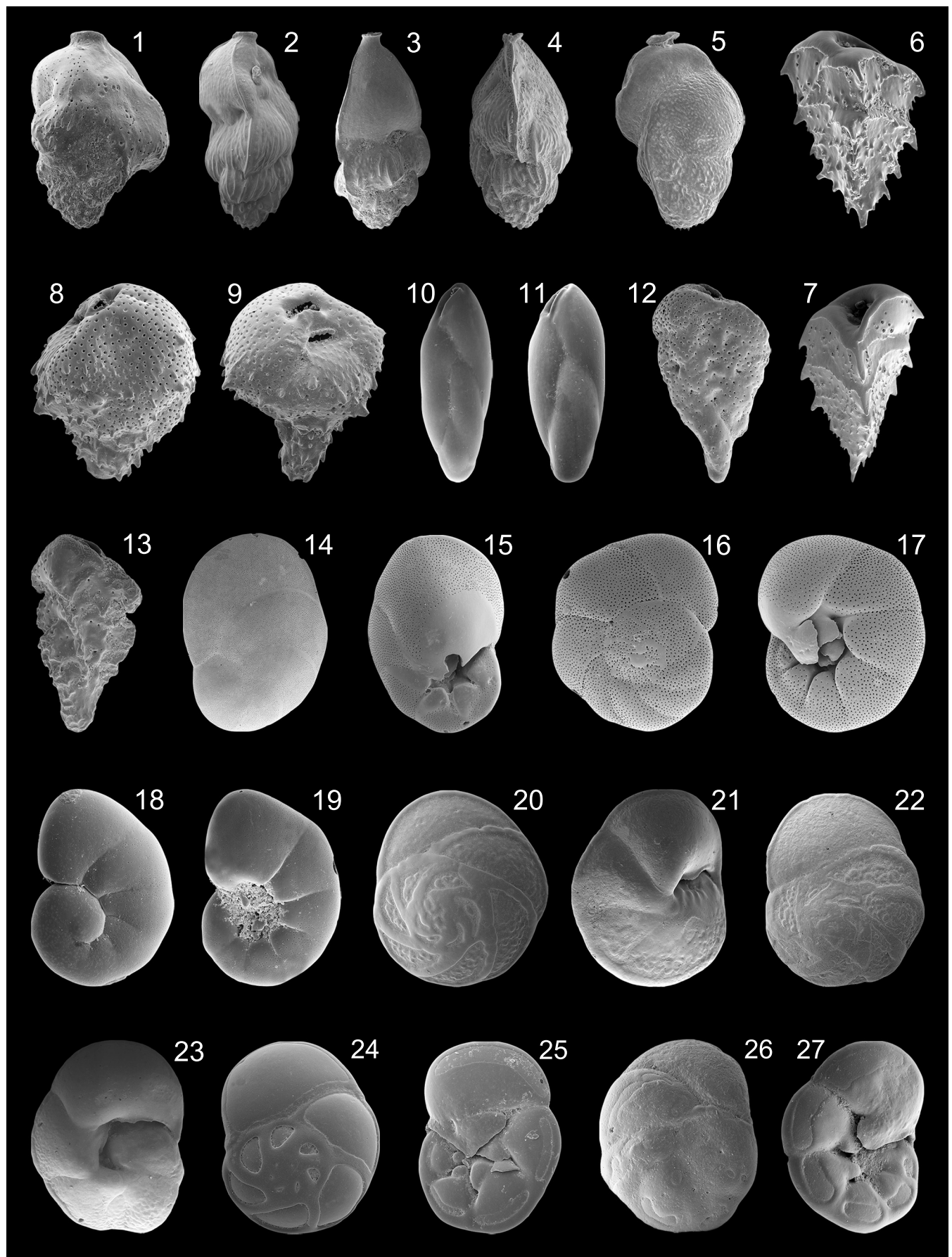

FIGURE 21. 1 Uvigerina sp. 1, 1280x, lateral view; 2 Angulogerina angulosa (Williamson), 902x, lateral view; 3 A. angulosa (Williamson), 877x, lateral view; 4 A. angulosa (Williamson), 993x, lateral view; 5 Trifarina fornasinii (Selli), 411x, lateral view; 6 Reussella spinulosa (Reuss), 804x, lateral view; 7 R. spinulosa (Reuss), 770x, lateral view; 8 Trimosina sp. 1, 1010x, lateral view; 9 Trimosina sp. 1, 690x, lateral view; 10 Fursenkoina acuta (d'Orbigny), 593x, lateral view; 11 F. acuta (d'Orbigny), 816x, lateral view; 12 Sigmavirgulina tortuosa (Brady), 657x, lateral view; 13 Sigmavirgulina sp. 1, 923x, lateral view; 14 Cancris auriculus (Fichtel and Moll), 371x, spiral side; 15 C. auriculus (Fichtel and Moll), 653x, umbilical side; 16 Valvulineria complanata (d'Orbigny), 388x, spiral side; $17 \mathrm{~V}$. complanata (d'Orbigny), 370x, umbilical side; 18 Valvulineria minuta Parker, 1220x, spiral side; 19 V. minuta Parker, 1190x, umbilical side; 20 Eponides concameratus (Williamson), 188x, spiral side; 21 E. concameratus (Williamson), 262x, umbilical side; 22 Eponides sp. 1, 200x, spiral side; 23 Eponides sp. 1, 145x, umbilical side; 24 Stomatorbina concentrica (Parker and Jones), 339x, spiral side; 25 S. concentrica (Parker and Jones), 295x, umbilical side; 26 Mississipina sp. 1, 702x, spiral side; 27 Mississipina sp. 1, 774x, umbilical side 
2003 Trifarina angulosa (Williamson); Murray, p. 26, fig. 10 , no. 5

2005 Angulogerina angulosa (Williamson); Debenay et al., p. 336 pl. 3, fig. 12

2005 Trifarina angulosa (Williamson); Rasmussen, p. 89, pl. 12, fig. 1

2008 Trifarina angulosa (Williamson); Abu-Zied et al., p. 52, pl. 2, fig. 21

2009 Trifarina angulosa (Williamson); Milker et al., p. 218 , pl. 3 , fig. 2

Remarks: The wall is calcareous and finely perforate. The test is subovate-elongate in lateral view and triangular in apertural view. The chamber arrangement is triserial with a tendency to a biserial chamber arrangement in the adult stage. Sutures are depressed and limbate. The periphery is carinate. The aperture is on a short neck, bordered by a lip and provided with a toothplate. The test surface is ornamented with tubercles and longitudinal striae and costae.

\section{Genus TRIFARINA Cushman, 1923 Trifarina fornasinii (Selli, 1948)} Figure 21.5

1948 Angulogerina fornasinii Selli: p. 40-44, figs. 1-4

1992 Trifarina fornasinii (Selli); Schiebel, p. 56, pl. 3, fig. 2

2005 Trifarina fornasinii (Selli); Rasmussen, p. 89 , pl. 12 , fig. 3

Remarks: The wall is calcareous. The test is ovate-elongate in lateral view and subtriangular in apertural view. Earlier chambers are triserially arranged, and later chambers are uniserially arranged and rectilinear. Chambers are inflated. Sutures are depressed. The periphery is carinate. The aperture is rounded, on an everted collar and provided with a toothplate. Short apical pseudospines are present, and the test surface is ornamented with irregularly arranged ridges.

Family REUSSELLIDAE Cushman, 1933a Genus REUSSELLA Galloway, 1933 Reussella spinulosa (Reuss, 1850)

Figure 21.6-7

1850 Verneuilina spinulosa Reuss: p. 10, pl. 12, fig. 12

1911 Verneuilina spinulosa Reuss; Cushman, p. 55, text-fig. 88

1987 Reussella spinulosa (Reuss); Alberola et al., p. 322, pl. 4, fig. 14
1987 Reussella spinulosa (Reuss); Jorissen, p. 41 , pl. 3, fig. 7

1988 Reussella spinulosa (Reuss); Loeblich and Tappan, p. 152, pl. 575, figs. 9-12

1991 Reussella spinulosa (Reuss); Cimerman and Langer, p. 63, pl. 66, figs. 5-8

1993 Reussella spinulosa (Reuss); Sgarrella and Moncharmont Zei, p. 214, pl. 15, fig. 14

2005 Reussella spinulosa (Reuss); Rasmussen, p. 90 , pl. 12 , fig. 4

2006 Reussella spinulosa (Reuss); Avsar et al., p. 133, pl. 2, fig. 7

2009 Reussella spinulosa (Reuss); Avsar et al., p. 134 , pl. 2, fig. 9

2009 Reussella spinulosa (Reuss); Milker et al., p. 218 , pl. 3 , figs. 4,5

Remarks: The wall is calcareous and perforate along the chamber margins. The test is triangular in lateral and in apertural view. Chambers are triserially arranged and acutely angled, gradually increasing in size as added. Sutures are distinct and thickened. The slit-like aperture is interiomarginal and provided with an internal toothplate. The test surface is ornamented with short pseudospines along the carinate chamber margins.

\section{Family TRIMOSINIDAE Saidova, 1975 Genus TRIMOSINA Cushman, 1927 Trimosina sp. 1 Figure 21.8-9}

Remarks: The wall is calcareous, hyaline and densely and finely perforate. The test is pyramidal in lateral view and subtriangular in apertural view. Chambers are triserially arranged and inflated, strongly increasing in size as added. Sutures are depressed. The primary aperture is an archshaped opening at the base of the final chamber, and partly bordered by a rim. A secondary, larger and arch-shaped opening is present on the final chamber. Chambers are ornamented with lateral rips, extending to short pseudospines on the lower chamber margin.

\section{Family FURSENKOINIDAE Loeblich and Tappan,} 1961

Genus FURSENKOINA Loeblich and Tappan, 1961

Fursenkoina acuta (d'Orbigny, 1846)

Figure 21.10-11

1846 Polymorphina acuta d'Orbigny: p. 234, PI. 13, figs. 4, 5; Pl. 14, figs. 5-7 
1991 Fursenkoina acuta (d'Orbigny); Cimerman and Langer, p. 64, pl. 67, figs. 1, 2

1993 Fursenkoina acuta (d'Orbigny); Sgarrella and Moncharmont Zei, p. 235, pl. 23, fig. 7

2002 Fursenkoina acuta (d'Orbigny); Kaminski et al., p. 174, pl. 3, figs. 11, 12

2005 Fursenkoina acuta (d'Orbigny); Rasmussen, p. 90 , pl. 12, fig. 8

2006 Fursenkoina acuta (d'Orbigny); Avsar et al., p. 133, pl. 2, fig. 8

2009 Fursenkoina acuta (d'Orbigny); Avsar et al., p. 135 , pl. 2, fig. 10

Remarks: The wall is calcareous, hyaline and finely perforate. The test is elongate in lateral view. Chambers are biserially arranged and slightly twisted around a vertical axis. The test surface is smooth. Sutures are oblique and depressed. The aperture is elongate, bordered weakly developed rim and provided with a toothplate.

$$
\begin{gathered}
\text { Genus SIGMAVIRGULINA Loeblich and Tappan, } \\
1957 \\
\text { Sigmavirgulina tortuosa (Brady, 1881) }
\end{gathered}
$$

Figure 21.12

1881 Bolivina tortuosa Brady: p. 57

1884 Bolivina tortuosa Brady; Brady, p. 420, pl. 52, figs. 31-34

1931 Bolivina tortuosa Brady; Cushman and Parker, p. 16, pl. 3, fig. 22

1988 Sigmavirgulina tortuosa (Brady); Loeblich and Tappan, p. 153 , pl. 579, figs. 1-5

1994 Sigmavirgulina tortuosa (Brady); Jones, $p$. 58, pl. 52, figs. 31-34 [cop. Brady, 1884, figs. 31-34]

Remarks: The wall is calcareous and densely and coarsely perforate. The test is triangular-elongate in lateral view and compressed in apertural view. Chambers are biserially arranged with a sigmoid alignment. Chambers increasing in breadth as added. The periphery is acutely carinate. Sutures are slightly depressed. The subterminal aperture, at the inner margin of the final chamber, is elongate-ovate, surrounded by a lip and provided with a toothplate. The test surface is smooth.

\section{Sigmavirgulina sp. 1}

Figure 21.13

1991 Sigmavirgulina sp. 1; Cimerman and Langer, p. 64, pl. 67, figs. 3-7

Remarks: The wall is calcareous and later chambers are coarsely perforate. The test is triangular- elongate in lateral view and compressed in apertural view. Chambers are biserially arranged with a sigmoid alignment. The periphery is acutely angled. Sutures are weakly depressed. The oval aperture, at the inner margin of the final chamber, is surrounded by a lip and provided with a toothplate.

Family BAGGINIDAE Cushman, 1927

Subfamily BAGGININAE Cushman, 1927

Genus CANCRIS de Montfort, 1808

Cancris auriculus (Fichtel and Moll, 1798)

Figure 21.14-15

1798 Nautilus auricula Fichtel and Moll: p. 108, pl. 20, figs. a, c, e, f

1884 Pulvinulina auricula (Fichtel and Moll); Brady, p. 688, pl. 106, fig. 4

1931 Cancris auricula (Fichtel and Moll); Cushman, p. 72 , pl. 15 , fig. 1

1988 Cancris auriculus (Fichtel and Moll); Loeblich and Tappan, p. 157, pl. 591, figs. 1-3

1993 Cancris auriculus (Fichtel and Moll); Hottinger, Halicz and Reiss, p. 106, pl. 136, figs. 6-14

1994 Cancris auriculus (Fichtel and Moll); Jones, p. 105, pl. 106, fig. 4 [cop. Brady 1884, fig. 4]

2005 Cancris auricula (Fichtel and Moll); Rasmussen, p. 91 , pl. 12, figs. 14, 15

2008 Cancris auriculus (Fichtel and Moll); AbuZied et al., p. 52, pl. 2, figs. 24, 25

2009 Cancris auriculus (Fichtel and Moll); Milker et al., p. 218, pl. 3, figs. 6, 7

Remarks: The wall is calcareous and finely and densely perforate except for the umbilical region. The biconvex test is auriculate in outline and lenticular in section. Chambers are trochospirally enrolled and strongly increasing in breadth as added. The spiral side is evolute, the umbilical side is involute. The periphery is acute and carinate. Sutures are depressed and arched on the spiral side and nearly radial on the umbilical side. The aperture is a low interiomarginal opening on the umbilical side and provided with a broad apertural flap. The test surface is smooth.

Genus VALVULINERIA Cushman, 1926

Valvulineria complanata (d'Orbigny, 1846)

Figure 21.16-17

1846 Rosalina complanata d'Orbigny: p.175, pl. 10 , figs. $13-15$ 
1958 Valvulineria complanata (d'Orbigny); Parker, p. 268, pl. 3, figs. 42-44

1987 Valvulineria bradyana (Fornasini); Jorissen, p. 43 , pl. 4 , fig. 2

1991 Valvulineria bradyana (Fornasini); Cimerman and Langer, p. 64, pl. 67, figs. 8-10

1993 Valvulineria bradyana (Fornasini); Sgarrella and Moncharmont Zei, p. 220, pl. 18, figs. 1, 2

1995 Valvulineria bradyana (Fornasini); Coppa and Di Tuoro, p. 170, pl. 3, figs. 3, 6

2004 Valvulineria bradyana (Fornasini); Chendes et al., p. 76, pl. 2, fig. 12

2005 Valvulineria complanata (d'Orbigny); Rasmussen, p. 91, pl. 12, figs. 16, 17

2006 Valvulineria complanata (d'Orbigny); Avsar et al., p. 133, pl. 2, figs. 9, 10

2009 Valvulineria bradyana (Fornasini); Avsar et al., p. 135, pl. 2, figs. 11, 12

2009 Valvulineria bradyana (Fornasini); Frezza and Carboni, p. 55, pl. 1, figs. 1, 2

2010 Valvulineria bradyana (Fornasini); Milker, p. 117 , pl. 4 , figs. 6,7

Remarks: The wall is calcareous and densely perforate except for the umbilical region. The test is rounded in outline. Chambers are trochospirally enrolled, gradually increasing in size as added. The spiral side is slightly convex and weakly depressed in the initial part. The umbilical side is involute with a depressed umbilicus. The periphery is subrounded. Sutures are depressed and backward curved on the spiral side, nearly radial and slightly curved on the umbilical side. The aperture is an interiomarginal, umbilical to extraumbilical arch, provided with a large flap, covering the umbilicus. The test surface is smooth. Valvulineria bradyana seems to be a junior synonym of $V$. complanata (see Parker, 1958 and Rasmussen, 2005).

Valvulineria minuta Parker, 1954

Figure 21.18-19

1954 Valvulineria minuta Parker: p. 527, pl. 9, figs. 4-6

1993 Valvulineria minuta Parker; Sgarrella and Moncharmont Zei, p. 220, pl. 18, figs. 3, 4

Remarks: The wall is calcareous and densely and finely perforate except for the umbilical region. The test is subrounded in outline. Chambers are tro- chospirally enrolled, gradually increasing in size as added. The spiral side is slightly convex and weakly appressed in the initial part. The umbilical side is involute with a depressed umbilicus. The periphery is subrounded. Sutures are depressed and slightly backwards curved on the spiral side and nearly radial on the umbilical side. The aperture is an interiomarginal, umbilical to extraumbilical arch, provided with a flap, partly covering the umbilicus. The test surface is smooth.

\section{Valvulineria sp. 1}

Remarks: The wall is calcareous, hyaline and more finely perforate compared to Valvulineria complanata. The test is rounded in outline. Chambers are trochospirally enrolled. Two and a half whorls are visible. Chambers are inflated, gradually increasing in size as added. Six chambers are visible in the final whorl. The periphery is rounded. The spiral side is flattened. The umbilical region is depressed. Sutures are backward curved and depressed on both sides. The aperture is an interiomarginal arch at the base of the final chamber and provided with a flap, partly covering the umbilicus. The test surface is smooth.

Family EPONIDIDAE Hofker, 1951a

Subfamily EPONIDINAE Hofker, 1951a

Genus EPONIDES de Montfort, 1808

Eponides concameratus (Williamson, 1858)

Figure 21.20-21

1858 Rotalina concamerata Williamson: p. 52, pl. 4, figs. 101-103 (not figs. 104, 105)

1931 Eponides repanda var. concamerata (Williamson); Cushman, p. 51, pl. 11, fig. 4 [cop. Williamson 1858, figs. 101-103]

1988 Eponides repandus (Fichtel and Moll); Loeblich and Tappan, p. 158, pl. 594, figs. 1-3

1991 Eponides concameratus (Williamson); Cimerman and Langer, p. 64, pl. 67, figs. 11-14

1993 Eponides repandus var. concamerata (Williamson); Sgarrella and Moncharmont Zei, p. 232, pl. 22, figs. 4,5

1995 Eponides repandus (Fichtel and Moll); Coppa and Di Tuoro, p. 172, pl. 4, figs. 8, 10

2005 Eponides repandus (Fichtel and Moll); Rasmussen, p. 92, pl. 13, figs. 1, 2

2009 Eponides concameratus (Williamson); Milker et al., p. 218, pl. 3, figs. 8, 9 
Remarks: The wall is calcareous and finely perforate except for the peripheral keel and the sutures. The test is rounded in outline and planoconvex to biconvex. Chambers are trochospirally enrolled. The spiral side is evolute, and the umbilical side is involute. The periphery is thickened and carinate. The spiral side is pustulate, with backward curved and thickened sutures. On the umbilical side, sutures are nearly radial and depressed. The aperture is an interiomarginal and extraumbilical arch, bordered by a lip on one side.

\section{Eponides sp. 1 \\ Figure 21.22-23}

Remarks: The wall is calcareous and finely perforate except for the peripheral keel and the sutures. The test is subrounded in outline and planoconvex to biconvex. Chambers are trochospirally enrolled. The spiral side is evolute, and the umbilical side is involute. The periphery is thickened and carinate. The spiral side is pustulate, with backward curved and thickened sutures. On the umbilical side, sutures are oblique and depressed. The aperture is an interiomarginal, extraumbilical large arched slit. This species differs from Eponides concameratus by the larger and curved apertural opening, and it is generally larger and more subrounded in outline than $E$. concameratus.

Family MISSISSIPPINIDAE Saidova, 1981 Subfamily STOMATORBININAE Saidova, 1981

Genus STOMATORBINA Dorreen, 1948

Stomatorbina concentrica (Parker and Jones, in Brady 1864)

Figure 21.24-25

1864 Pulvinulina concentrica Parker and Jones: type reference Brady, 1864, p. 470, pl. 48, fig. 14

1884 Pulvinulina concentrica Parker and Jones; Brady, p. 686, pl. 105, fig. 1

1931 Eponides concentrica (Parker and Jones); Cushman, p. 43, pl. 9, figs. 4, 5 [fig. 4: cop. Brady, 1884, fig. 1]

1991 Stomatorbina concentrica (Parker and Jones); Cimerman and Langer, p. 65, pl. 68, figs. 7-9

1993 Stomatorbina concentrica (Parker and Jones); Sgarrella and Moncharmont Zei, $p$. 232, pl. 26, figs. 9, 10

1994 Mississippina concentrica (Parker and Jones); Jones, p. 104, pl. 105, fig. 1 [cop. Brady. 1884, fig. 1]
2005 Stomatorbina concentrica (Parker and Jones); Rasmussen, p. 92, pl. 13, figs. 3, 4

2009 Stomatorbina concentrica (Parker and Jones); Milker et al., p. 218, pl. 3, figs. 10, 11

Remarks: The wall is calcareous. The test is subrounded in outline, low trochospirally coiled and unequally biconvex. Chambers increasing in size as added. Sutures are thickened and curved on the evolute spiral side, depressed and nearly radial on the involute umbilical side. The periphery is subangular. The aperture is an interiomarginal arch, extending into the open umbilicus. The test surface is smooth, with elliptical inframarginal areas on the umbilical side.

\section{Subfamily MISSISSIPPININAE Saidova, 1981 Genus MISSISSIPPINA Howe, 1930 Mississippina sp. 1 Figure 21.26-27}

Remarks: The wall is calcareous and finely perforate. The test is subrounded in outline, low trochospirally coiled and unequally biconvex. The spiral side is evolute, and the umbilical side is involute. Six chambers are visible in the final whorl, increasing in size as added. Sutures are depressed and curved on both sides. The periphery is subacute. The aperture is an interiomarginal arch, extending into the open umbilicus, and is covered by an umbilical flap. The test surface is smooth, with elliptical inframarginal areas on both sides.

Family DISCORBIDAE Ehrenberg, 1838 Genus DISCORBIS Lamarck, 1804

Discorbis williamsoni Chapman and Parr, in Parr 1932

Figure 22.1-2

1858 Rotalina nitida Williamson: p. 54, pl. 4, figs. 106-108

1916 Discorbina nitida (Williamson); HeronAllen and Earland, p. 269, pl. 42, figs. 2630

1931 Discorbis nitida (Williamson); Cushman, p. 26, pl. 6, fig. 1

1932 Discorbis williamsoni Chapman and Parr: type reference, Parr, 1932, p. 226, pl. 21, fig. 25

1977 Neoconorbina williamsoni (Chapman and Parr); Hofker, p. 244, pl. 5, fig. 2

2005 Discorbis williamsoni Chapman and Parr; Rasmussen, p. 93, pl. 13, figs. 7, 8 


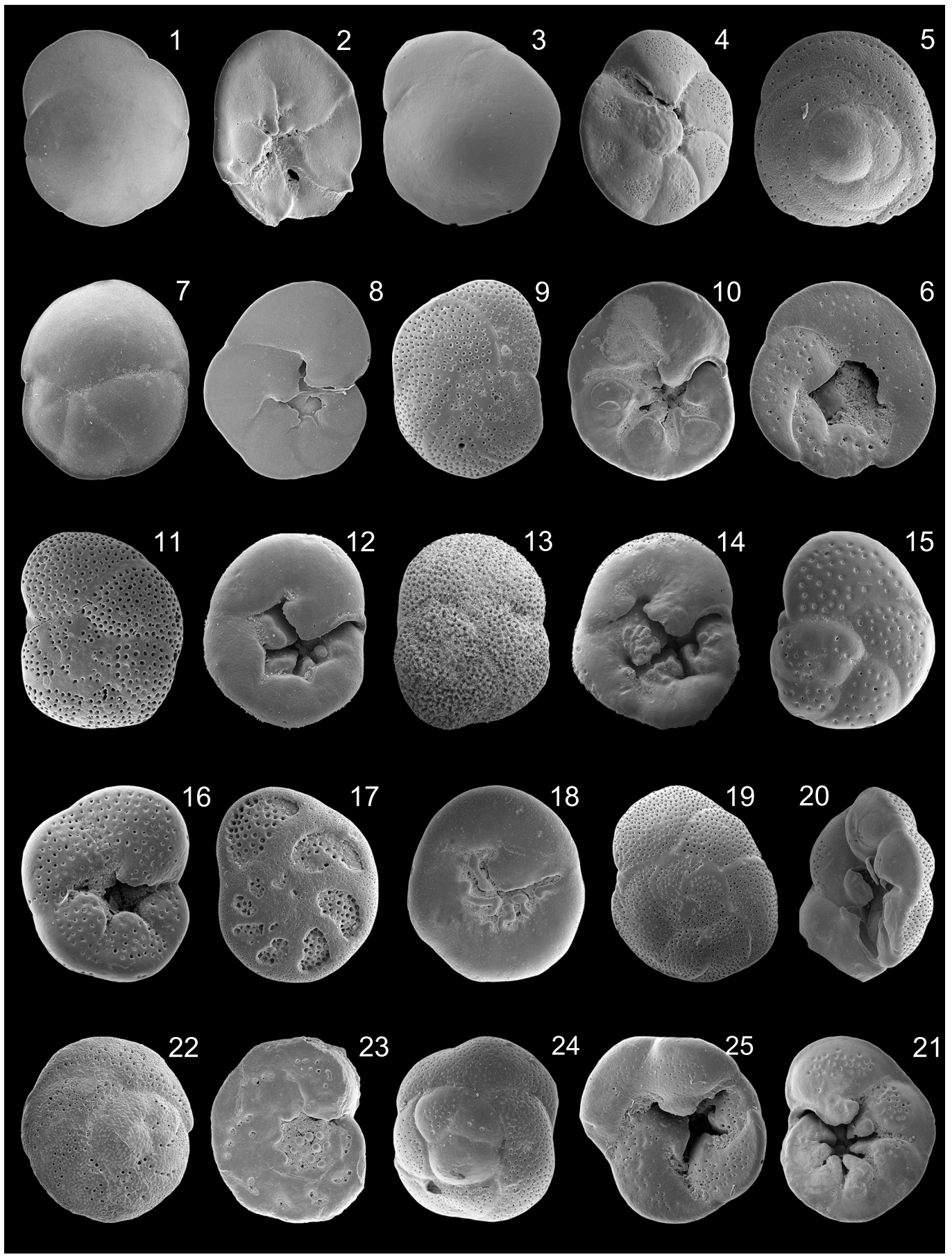

FIGURE 22. 1 Discorbis williamsoni Chapman and Parr, 635x, spiral side; 2 D. williamsoni Chapman and Parr, 1060x, umbilical side; 3 Gavelinopsis praegeri (Heron Allen and Earland), 758x, spiral side; 4 G. praegeri (Heron Allen and Earland), 987x, umbilical side; 5 Neoconorbina terquemi (Rzehak), 545x, spiral side; 6 N. terquemi (Rzehak), 732x, umbilical side; 7 Planodiscorbis rarescens (Brady), 341x, spiral side; 8 P. rarescens (Brady), 281x, umbilical side; 9 Rosalina anomala Terquem, 376x, spiral side; $10 R$. anomala Terquem, 432x, umbilical side; 11 Rosalina bradyi Cushman, 782x, spiral side; 12 R. bradyi Cushman, 768x, umbilical side; $13 R$. bradyi Cushman, 370x, spiral side; $14 R$. bradyi Cushman, 324x, umbilical side; 15 Rosalina globularis d'Orbigny, 829x, spiral side; 16 R. globularis d'Orbigny, 824x, umbilical side; 17 Rosalina macropora (Hofker), 766x, spiral side; $18 R$. macropora (Hofker), 407x, umbilical side; 19 Rosalina sp. 1, 243x, spiral side; 20 Rosalina sp. 1, 345x, umbilical side; 21 Rosalina sp. 1, 348x, umbilical side; 22 Spirorbina? sp. 1, 707x, spiral side; 23 Spirorbina? sp. 1, 886x, umbilical side; 24 Tretomphalus concinnus (Brady), 671x, spiral side; 25 T. concinnus (Brady), 573x, umbilical side. 
Remarks: The wall is calcareous, thin and translucent. The test is circular in outline. Chambers are low trochospirally enrolled. The spiral side is convex and the umbilical side is flattened. Sutures are backward curved and flush with the surface on the spiral side, nearly radial, curved and depressed on the umbilical side. The periphery is subacute. The aperture is a low interiomarginal and extraumbilical arch on the umbilical side. The test surface is smooth. The umbilical side is finely perforate, and triangular chamber flaps are visible in the umbilical region.

Family ROSALINIDAE Reiss, 1963

Genus GAVELINOPSIS Hofker, 1951a

Gavelinopsis praegeri (Heron-Allen and Earland, 1913)

Figure 22.3-4

1913 Discorbina praegeri Heron-Allen and Earland: p. 122, pl. 10, figs. 8-10

1931 Discorbis? praegeri (Heron-Allen and Earland); Cushman, p. 30, pl. 6, fig. 4 [cop. Heron-Allen and Earland, 1913, figs. 8-10]

1958 Gavelinopsis praegeri (Heron-Allen and Earland); Parker, p. 264, pl. 3, figs. 24, 25

1960 Gavelinopsis praegeri (Heron-Allen and Earland); Hofker, p. 252, pl. D, fig. 114

1987 Gavelinopsis praegeri (Heron-Allen and Earland); Jorissen, p. 41, pl. 3, fig. 13

1988 Gavelinopsis praegeri (Heron-Allen and Earland); Loeblich and Tappan, p. 161, pl. 608, figs. 6-12

1991 Gavelinopsis praegeri (Heron-Allen and Earland); Cimerman and Langer, p. 66, pl. 70, figs. 3, 4

1992 Gavelinopsis praegeri (Heron-Allen and Earland); Schiebel, p. 46, pl. 4, fig. 6

1993 Gavelinopsis praegeri (Heron-Allen and Earland); Sgarrella and Moncharmont Zei, p. 218 , pl. 17, figs. 1,2

2003 Gavelinopsis praegeri (Heron-Allen and Earland); Murray, p. 24, fig. 8, no. 5, 6

2009 Gavelinopsis praegeri (Heron-Allen and Earland); Milker et al., p. 218, pl. 3, figs. 14,15

Remarks: The wall is calcareous, hyaline and finely perforate toward the periphery on the umbilical side. The test is circular in outline. Chambers are low trochospirally enrolled. The spiral side is evolute and convex with thickened and flush sutures. The umbilical side is involute and slightly convex with subtriangular chambers and radial and depressed sutures around an umbilical plug. The periphery is carinate. The aperture is an interiomarginal, extraumbilical slit on the umbilical side, partly bordered by a small lip.

Genus NEOCONORBINA Hofker, 1951b

Neoconorbina terquemi (Rzehak, 1888)

Figure 22.5-6

1884 Discorbina orbicularis Terquem; Brady, p. 647, pl. 88, figs. 5-8

1888 Discorbina terquemi Rzehak: p. 228

1958 Neoconorbina terquemi (Rzehak); Parker, p. 267 , pl. 3 , figs. 26,27

1960 Neoconorbina neapolitana Hofker; Hofker, p. 252, pl. D, fig. 115

1987 Neoconorbina terquemi (Rzehak); Alberola et al., p. 308, pl. 4, fig. 9

1987 Neoconorbina terquemi (Rzehak); Jorissen, p. 40 , pl. 3, figs. 3,4

1988 Neoconorbina terquemi (Rzehak); Loeblich and Tappan, p. 161, pl. 609, figs. 8-10

1991 Neoconorbina terquemi (Rzehak); Cimerman and Langer, p. 66, pl. 70, figs. 5-7

1993 Neoconorbina terquemi (Rzehak); Sgarrella and Moncharmont Zei, p. 218, pl. 17, fig. 3

1994 Neoconorbina terquemi (Rzehak); Jones, p. 94 , pl. 88, figs. 5-8 [cop. Brady, 1884, figs. 5-8]

2005 Neoconorbina terquemi (Rzehak); Rasmussen, p. 93, pl. 13, figs. 11, 12

2006 Neoconorbina terquemi (Rzehak); Avsar et al., p. 133, pl. 2, fig. 16

2008 Neoconorbina terquemi (Rzehak); AbuZied et al., p. 52, pl. 2, figs. 26, 27

2009 Neoconorbina terquemi (Rzehak); Milker et al., p. 218, pl. 3, figs. 16, 17

Remarks: The wall is calcareous. The test is circular in outline and and low conical in section. Chambers are trochospirally enrolled, increasing in breath as added. The spiral side is evolute with long and crescentic chambers. The umbilical side is involute with subtriangular chambers. Sutures are slightly backward curved and depressed on both sides. The umbilicus is open. The aperture is an elongate, interiomarginal and extraumbilical slit on the umbilical side. The spiral side is coarsely perforate along the chamber margins, and cham- 
bers are finely perforate. The umbilical side is coarsely perforate.

Genus PLANODISCORBIS Bermudez, 1952 Planodiscorbis rarescens (Brady, 1884)

Figure 22.7-8

1884 Discorbis rarescens Brady: p. 651, pl. 90, figs. 2, 3

1915 Discorbis rarescens Brady; Cushman, $\mathrm{p}$. 20, pl. 7, fig. 4 [cop. Brady. 1884, fig. 2]

1958 Planodiscorbis rarescens (Brady); Todd, p. 196, pl. 1, fig. 17

1994 Planodiscorbis rarescens (Brady); Jones, p. 94, pl. 90, figs. 2, 3 [cop. Brady, 1884, figs. 2, 3]

Remarks: The wall is calcareous and finely and densely perforate on both sides. The test is trochospiral and planoconvex. Chambers are broad, low and crescentic on the convex spiral side, and are subtriangular and overlapping each other on the flattened umbilical side. Early chambers have thickened sutures, flush with the surface on the spiral side. Later sutures are depressed and oblique. Sutures are curved, radial and depressed on the umbilical side. The periphery is carinate. The umbilicus is closed. The aperture is a low interiomarginal arch at the base of the final chamber. The test surface is smooth.

Genus ROSALINA d'Orbigny, 1826

Rosalina anomala Terquem, 1875

Figure 22.9-10

1858 Rotalina concamerata Williamson; p. 52, pl. 4, figs. 104, 105

1875 Rosalina anomala Terquem: p. 438, pl. 5, fig. 1

1931 Discorbis globularis (d'Orbigny); Cushman, p. 22, pl. 4, fig. 9

1973 Rosalina anomala Terquem; Haynes, p. 150, pl. 17, figs. 1-3; pl. 19, fig. 2; text-fig. 28

2003 Rosalina anomala Terquem; Murray, p. 26, fig. 9, no. 9, 10

2006 Rosalina anomala Terquem; Wisshak and Rueggenberg, p. 4, fig. 3J, K

2009 Rosalina floridensis (Cushman); Milker et al., p. 218, pl. 3, figs. 18, 19

Remarks: The wall is calcareous. The test is trochospiral and planoconvex. Chambers rapidly increasing in size as added. Chambers are crescentic and densely perforate and sutures are back- ward curved and slightly elevated on the spiral side. Chambers are imperforate and subtriangular, with a flap at their base, on the umbilical side. The periphery is subacute. The primary aperture is an interiomarginal and extraumbilical arched slit, bordered by a lip. The test surface is smooth.

\section{Rosalina bradyi Cushman, 1915}

Figure 22.11-14

1884 Discorbina globularis d'Orbigny; Brady, p. 634 , pl. 86 , fig. 8

1915 Rosalina globularis (d'Orbigny) var. bradyi Cushman: p. 12, pl. 8, fig. 1

1987 Rosalina bradyi Cushman; Jorissen, p. 41, pl. 3, fig. 6

1991 Rosalina bradyi Cushman; Cimerman and Langer, p. 66, pl. 71, figs. 1-5

1993 Rosalina bradyi Cushman; Hottinger, Halicz and Reiss, p. 110, pl. 142, fig. 12; pl. 143, figs. 1-6

1994 Rosalina bradyi Cushman; Jones, p. 93, pl. 86, fig. 8 [cop. Brady, 1884, fig. 8]

2005 Rosalina bradyi Cushman; Debenay et al., p. 336 pl. 3, figs. 21,22

2006 Rosalina bradyi Cushman; Avsar et al., p. 133, pl. 2, figs. 13,14

2008 Rosalina bradyi Cushman; Abu-Zied et al., p. 52 , pl. 2, figs. 28,29

Remarks: The wall is calcareous. The test is low trochospiral with a rounded periphery. The spiral side is evolute and weakly convex with crescentic and densely and coarsely perforate chambers. Pores can be surrounded by weak polygonal ridges on which pseudospines are present in the adult stage. The umbilical side is evolute with triangular and imperforate chambers, strongly increasing in size as added and overlapping each other. The umbilicus is open. Sutures are depressed and backward curved on the spiral side. The primary aperture is an interiomarginal, extraumbilical arched slit, extending from the periphery to the umbilicus, and is provided with a thickened lip.

Rosalina globularis d'Orbigny, 1826

Figure 22.15-16

1826 Rosalina globularis d'Orbigny: p. 271, pl. 13 , figs. 1-4

1988 Rosalina globularis d'Orbigny; Loeblich and Tappan, p. 161, pl. 610, figs. 1-5; pl. 611 , figs. $1-3$ 
2005 Rosalina globularis d'Orbigny; Rasmussen, p. 94, pl. 14, fig. 1

Remarks: The test is calcareous, hyaline and densely perforate on both sides. The test is planoconvex to concavoconvex with a rounded periphery. The spiral side is convex, the umbilical side is flattened to concave with a depressed umbilical region. About five inflated chambers are visible in the final whorl on the spiral side. Chambers are subtriangular on the umbilical side. Sutures are depressed and backward curved on the spiral side and nearly radial and oblique on the umbilical side. The aperture is an interiomarginal, extraumbilical elongate slit, extending into the open umbilicus. The test surface is smooth.

Rosalina macropora (Hofker, 1951a)

Figure 22.17-18

1951a Discopulvinulina macropora Hofker: p. 460, figs. 312,313

1960 Discopulvinulina macropora Hofker; Hofker, p. 253, pl. D, fig. 122

1991 Rosalina macropora (Hofker); Cimerman and Langer, p. 67, pl. 71, figs. 6, 7

1993 Rosalina bradyi (Cushman); Sgarrella and Moncharmont Zei, p. 218, pl. 17, figs. 4, 5

1995 Rosalina bradyi (Cushman); Coppa and Di Tuoro, p. 168, pl. 2, figs. 12, 13

2004 Rosalina macropora (Hofker); Fiorini, p. 50, pl. 1, figs. 14,15

2005 Rosalina macropora (Hofker); Rasmussen, p. 95 , pl. 14, figs. 3,4

2009 Rosalina macropora (Hofker); Milker et al., p. 218 , pl. 3 , fig. 20

Remarks: The wall is calcareous. The test is low trochospiral and nearly planoconvex. The spiral side is evolute and slightly convex with crescentic and coarsely and densely perforate chambers and thickened and elevated sutures that are finely perforate. The umbilical side is involute with backward curved sutures that are flush with the surface. Chambers are subtriangular and partly finely perforate on the umbilical side. The periphery is carinate and imperforate. The aperture is an interiomarginal, extraumbilical arched slit.

Rosalina sp. 1

Figure 22.19-21

1993 cf. Rosalina sp. A; Hottinger, Halicz and Reiss, p. 112, pl. 145, figs. 1-4
2009 Rosalina sp. 5; Milker et al., p. 216, pl. 2, fig. 21

Remarks: The wall is calcareous. The test is low trochospiral. The spiral side is slightly convex and evolute, the umbilical side is involute and slightly concave. The test shape is often irregular. Six to seven coarsely and densely perforate and crescentic chambers are visible in the adult coil on the spiral side, rapidly increasing in size as added. Chambers are subtriangular on the umbilical side and provided with an umbilical flap at the base. Later chambers can be coarsely perforate. Sutures are thickened, backward curved on the spiral side and depressed and curved on the umbilical side. The aperture is an interiomarginal, extraumbilical low arch with a distinct lip.

Genus SPIRORBINA Sellier de Civrieux, 1977 Spirorbina? sp. 1

Figure 22.22-23

Remarks: The wall is calcareous and finely perforate on the spiral side. The umbilical side is imperforate or has a few large pores parallel to the sutures. The test is circular in outline, low trochospiral and planoconvex. The spiral side is weakly convex and evolute with one and a half whorls of broad and low semilunate chambers. Six to seven chambers are visible in the final whorl. Sutures are backward curved and flush with the surface on the spiral side, except for the suture of the final chamber that is depressed. The umbilical side is flattened and partially involute with large pustules in the umbilical region. The sutures are backward curved, flush and obscure. The periphery is subacute. The aperture is a low slit, extending from near the periphery along the umbilical chamber margin to the preceding suture and then continuing along the spiral suture. The species almost resemble the morphological features described for Spirorbina in Loeblich and Tappan (1988) except for the large observed pustules in the umbilical region. Further study is necessary for a correct identification.

Genus TRETOMPHALUS Moebius, 1880

Tretomphalus concinnus (Brady, 1884)

Figure 22.24-25

1884 Discorbina concinna Brady: p. 646, pl. 90, fig. 7

1915 Discorbis concinna (Brady); Cushman, p. 16, pl. 5, fig. 3 [cop. Brady, 1884, fig. 7]

1988 Tretomphaloides concinnus (Brady); Loeblich and Tappan, p. 162, pl. 613, figs. 1-6 
1991

Tretomphalus bulloides (d'Orbigny); Cimerman and Langer, p. 67, pl. 72, figs. 3-5

1993 Tretomphalus concinnus (Brady); Sgarrella and Moncharmont Zei, p. 219, pl. 17, figs. 11,12

1994 Tretomphalus concinnus (Brady); Jones, $p$. 96, pl. 90, fig. 7 [cop. Brady, 1884, fig. 7]

Remarks: The wall is calcareous. The test is subcircular in outline, low trochospiral and flattened in the benthic stage and has a floating chamber in the planktonic stage. The spiral side is evolute with densely perforate chambers and an imperforate proloculus. Sutures are slightly sinuate, backward curved and depressed on the spiral side. Chambers rapidly increasing in length as added. The umbilical side of the benthic stage is involute and slightly concave with subtriangular and perforate chambers having basal flaps that extend into the open umbilicus. The periphery is subacute in the benthic stage. The aperture is an interiomarginal, extraumbilical slit, partly bordered by a lip. The test surface is smooth.

\section{Tretomphalus sp. 1 \\ Figure 23.1-2}

Remarks: The wall is calcareous. The test is subcircular in outline, low trochospiral and flattened in the benthic stage and has a floating chamber in the planktonic stage. The spiral side is evolute with imperforate chambers and periphery. Sutures are slightly sinuate, backward curved and depressed. Chambers rapidly increase in length as added. The umbilical side of the benthic stage is involute and slightly concave with subtriangular and perforate chambers, having basal flaps, extending into the umbilical region. The periphery is subacute in the benthic stage. The aperture is an interiomarginal, extraumbilical slit, bordered by an everted lip. The test surface is smooth.

Family SPHAEROIDINIDAE Cushman, 1927 Genus SPHAEROIDINA d'Orbigny, 1826

Sphaeroidina bulloides d'Orbigny, 1826

Figure 23.3-4

1826 Sphaeroidina bulloides d'Orbigny: p. 267

1832 Sphaeroidina bulloides d'Orbigny; Deshayes, p. 966

1884 Sphaeroidina bulloides d'Orbigny; Brady, p. 620 , pl. 84 , figs. 1,2

1914 Sphaeroidina bulloides d'Orbigny; Cushman, p. 18, pl. 12, fig. 1
1960 Sphaeroidina bulloides d'Orbigny; Hofker, p. 251, pl. D, fig. 107

1988 Sphaeroidina bulloides d'Orbigny; Loeblich and Tappan, p. 162, pl. 617, figs. 1-6

1990 Sphaeroidina bulloides d'Orbigny; Hasegawa et al., p. 477, pl. 4, figs. 10, 11

1994 Sphaeroidina bulloides Deshayes; Jones, p. 91 , pl. 84 , figs. 1,2 [cop. Brady, 1884, figs. 1, 2]

2005 Sphaeroidina bulloides d'Orbigny; Rasmussen, p. 95, pl. 14, fig. 11

Remarks: The wall is calcareous with a smooth and minutely perforate surface. The test is subglobular and spherical with a few inflated chambers. Sutures are depressed. The aperture is arched, semicircular and nearly closed by a broad flap.

Family GLABRATELLIDAE Loeblich and Tappan, 1964

Genus CONORBELLA Hofker, 1951a

Conorbella pulvinata (Brady, 1884)

Figure 23.5-6

1884 Discorbina pulvinata Brady: p. 650, pl. 88, fig. 10

1915 Discorbina pulvinata Brady; Cushman, p. 19, pl. 7, fig. 2 [text-fig. 22: cop. Brady, 1884, fig. 10]

1988 Conorbella pulvinata (Brady); Loeblich and Tappan, p. 163, pl. 618, figs. 4-6

1991 Conorbella pulvinata (Brady); Cimerman and Langer, p. 68, pl. 73, figs. 4-7

1994 Glabratella pulvinata (Brady); Jones, p. 94, pl. 88, fig. 10 [cop. Brady, 1884, fig. 10]

2005 Glabratella pulvinata (Brady); Rasmussen, p. 96 , pl. 14 , figs. 12,13

Remarks: The test is circular in outline, trochospiral and planoconvex. The spiral side is convex with crescentic chambers, increasing in size as added and having a rugose surface. The umbilical region is depressed on the umbilical side. Sutures are thickened, oblique, depressed and curved on the spiral side and flush and radial on the disc-like umbilical side. The umbilical side is ornamented with radially arranged pustules. The wall is calcareous. The aperture is an interiomarginal and umbilical slit.

\section{Genus DISCORBINOIDES Saidova, 1975} Discorbinoides sp. 1

Figure 23.7-9 


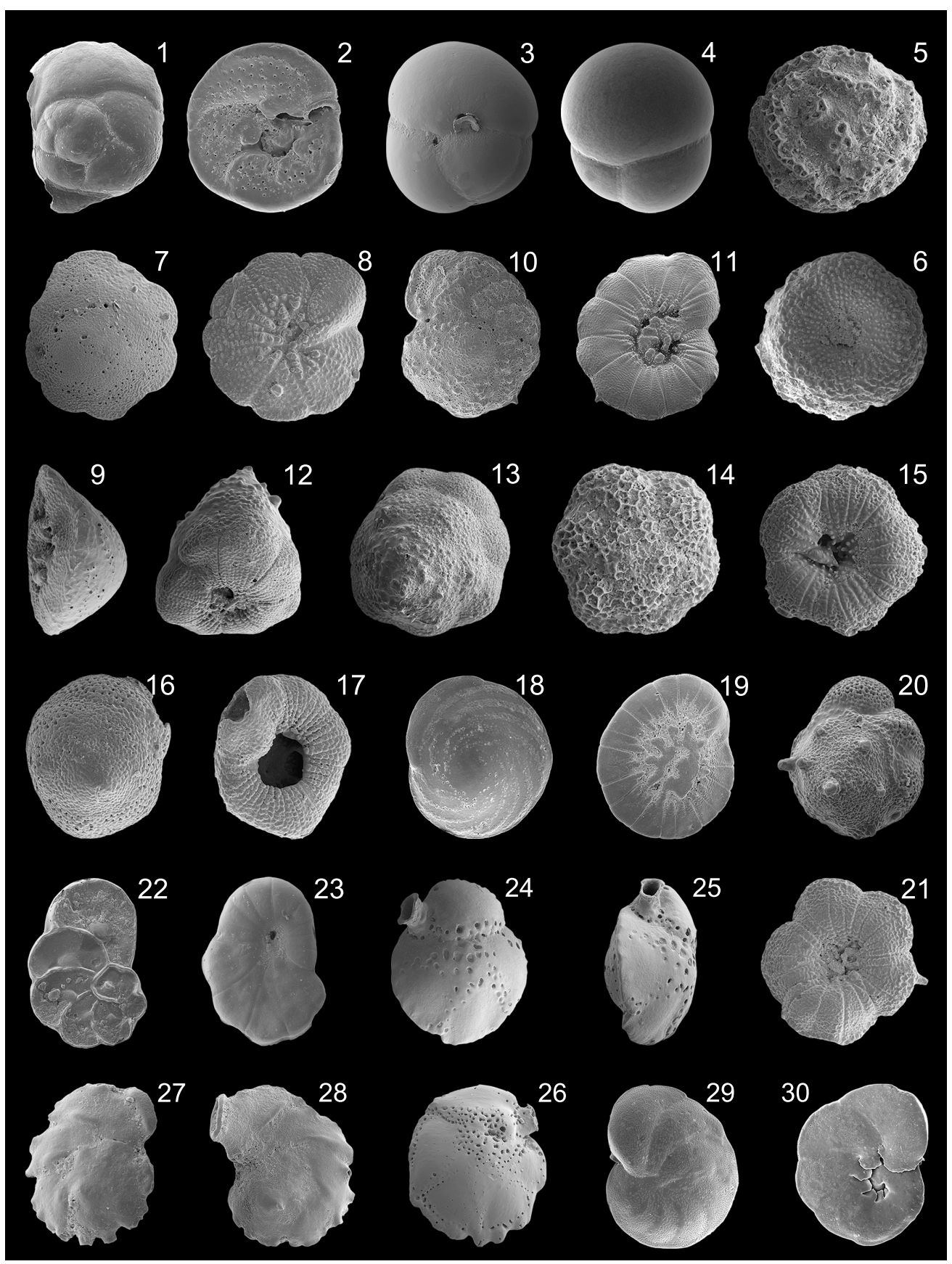

FIGURE 23. 1 Tretomphalus sp. 1, 990x, spiral side; 2 Tretomphalus sp. 1, 1060x, umbilical side; 3 Sphaeroidina bulloides d'Orbigny, 345x, side view; 4 S. bulloides d'Orbigny, 589x, side view; 5 Conorbella pulvinata (Brady), 936x, spiral side; 6 C. pulvinata (Brady), 931x, umbilical side; 7 Discorbinoides sp. 1, 657x, spiral side; 8 Discorbinoides sp. 1, 556x, umbilical side; 9 Discorbinoides sp. 1, 493x, peripheral side; 10 Discorbinoides? sp. 2, 466x, spiral side; 11 Discorbinoides? sp. 2, 481x, umbilical side; 12 Glabratella erecta (Sidebottom), 699x, oblique lateral view; 13 G. erecta (Sidebottom), 760x, top view; 14 Glabratella hexacamerata Seiglie and Bermudez, 907x, spiral side; 15 G. hexacamerata Seiglie and Bermudez, 727x, umbilical side; 16 Glabratella patelliformis (Brady), 1230x, spiral side; 17 G. patelliformis (Brady), 1020x, umbilical side; 18 Planoglabratella opercularis (d'Orbigny), 386x, spiral side; $19 P$. opercularis (d'Orbigny), 555x, umbilical side; 20 Schackoinella imperiatoria (d'Orbigny), 1090x, spiral side; 21 S. imperiatoria (d'Orbigny), 755x, umbilical side; 22 Heronallenia lingulata (Burrows and Holland), 543x, spiral side; 23 H. lingulata (Burrows and Holland), 570x, umbilical side; 24 Siphonina reticulata (Czjzek), 633x, side view; 25 S. reticulata (Czjzek), 474x, peripheral view; 26 S. reticulata (Czjzek), 586x, side view; 27 Siphoninella soluta (Brady), 1020x, side view; 28 S. soluta (Brady), 925x, side view; 29 Discorbinella bertheloti (d'Orbigny), 603x, spiral side; 30 D. bertheloti (d'Orbigny), 500x, umbilical side. 
Remarks: The wall is calcareous and densely and finely perforate on the spiral side. The test is low conical, trochospiral and nearly planoconvex. The spiral side is convex with three to four whorls. The umbilical side is flattened with a depressed umbilical region. Chambers are crescentic on the spiral side and subtriangular on the umbilical side. Sutures are thickened, oblique and flush with the surface on the spiral side and depressed, radial and curved on the umbilical side. The periphery is angular. The aperture is a low interiomarginal, extraumbilical slit at the periphery. Radiate grooves alternate with radiate fine pustules on the umbilical side. In the umbilical region, larger pustules are present.

\section{Discorbinoides? sp. 2}

Figure 23.10-11

Remarks: The wall is calcareous. The test is low conical, trochospiral and nearly planoconvex. Three whorls are visible on the spiral side. The chambers of the final whorl on the spiral side are crescentic and perforate. Sutures are thickened, oblique and flush with the surface to slightly depressed on the spiral side and radial, curved and depressed on the umbilical side. The umbilical side is ornamented with pustules and granules in the umbilical part and with radial striae, extending from the periphery to the umbilical region. The periphery is angular and a few short spines may be present there. The aperture is an interiomarginal slit near the peripheral margin on the final chamber. The test surface of the spiral side is rough.

Genus GLABRATELLA Dorreen, 1948

Glabratella erecta (Sidebottom, 1908)

Figure 23.12-13

1908 Discorbina erecta Sidebottom: p. 16, pl. 5, figs. 6, 7

1991 Conorbella erecta (Sidebottom); Cimerman and Langer, p. 68, pl. 72, figs. 6-8

1993 Glabratella erecta (Sidebottom); Sgarrella and Moncharmont Zei, p. 220, pl. 18, figs. 7,8

Remarks: The wall is calcareous. The test is high trochospiral and triangular in peripheral view. Chambers on the spiral side are inflated and globular, increasing size as added. Sutures are curved and depressed on the spiral side. The umbilical side is flattened with a depressed umbilical region. The periphery is subrounded. The aperture is a low interiomarginal slit. The spiral side is ornamented with pustules. The umbilical side is ornamented with radial striae and pustules. The test surface is rough.

\section{Glabratella hexacamerata Seiglie and Bermudez,} 1965

Figure 23.14-15

1965 Glabratella hexacamerata Seiglie and Bermudez: p. 31, pl. 1, figs. 6, 7

1967 Glabratella hexacamerata Seiglie and Bermudez; Seiglie, p. 107

1993 Glabratella hexacamerata Seiglie and Bermudez; Sgarrella and Moncharmont Zei, $p$. 222, pl. 18, figs. 9, 10

Remarks: The wall is calcareous. The test is low trochospiral and planoconvex. Chambers on the spiral side are inflated and globular, increasing in size as added. Sutures are curved and depressed on the spiral side. The umbilical side is flattened with a depressed umbilical region. The periphery is subrounded. The aperture is a low interiomarginal slit. The spiral side has a rugose surface. The umbilical side is ornamented with radial striae and pustules.

Glabratella patelliformis (Brady, 1884) Figure 23.16-17

1884 Discorbis patelliformis Brady: p. 647, pl. 88, fig. 3

1915 Discorbis patelliformis Brady; Cushman, $p$. 17, pl. 5, fig. 5 [text-fig. 19: cop. Brady 1884, fig. 3]

1991 Glabratella patelliformis (Brady); Cimerman and Langer, p. 68, pl. 73, figs. 1-3

1994 Glabratella patelliformes (Brady); Jones, p. 94, pl. 88, fig. 3 [cop. Brady, 1884, fig. 3]

Remarks: The wall is calcareous. The test is trochospiral, planoconvex and subtriangular in peripheral view. Chambers are crescentic, increasing size as added, on the convex spiral side. Sutures are curved and flush with the surface on the spiral side. The umbilical side is flattened with a depressed umbilical region. The periphery is subrounded. The aperture is a low interiomarginal slit. The spiral side has a rough surface and is perforate. The umbilical side is ornamented with radial pustules.

\section{Genus PLANOGLABRATELLA Seiglie and Bermudez, 1965 \\ Planoglabratella opercularis (d'Orbigny, 1826) Figure 23.18-19}


1826 Rosalina opercularis d'Orbigny: p. 271, no. 7

1988 Planoglabratella opercularis (d'Orbigny); Loeblich and Tappan, p. 164, pl. 621, figs. 21-23

1993 Planoglabratella opercularis (d'Orbigny); Sgarrella and Moncharmont Zei, p. 222, pl. 19, figs. 4,5

2009 Planoglabratella opercularis (d'Orbigny); Avsar et al., p. 135, pl. 2, figs. 15, 16

Remarks: The wall is calcareous and perforate along the sutures on the spiral side. The test is circular in outline, trochospiral and planoconvex with a subangular periphery. Chambers are narrow, elongate and numerous. Sutures are strongly curved and flush with the surface on both sides. The aperture is an interiomarginal slit near the peripheral margin of the final chamber. The spiral side has a smooth surface. The umbilical side is ornamented with granules in the closed umbilical part and with radial striae, extending from the periphery to the umbilical region.

Genus SCHACKOINELLA Weinhandl, 1958

Schackoinella imperiatoria (d'Orbigny, 1846)

Figure 23.20-21

1846 Rosalina imperiatoria d'Orbigny: p. 176, pl. 10, figs. $16-18$

1991 Conorbella imperiatoria (d'Orbigny); Cimerman and Langer, p. 68, pl. 72, figs. 9-11

1993 Schackoinella imperiatoria (d'Orbigny); Sgarrella and Moncharmont Zei, p. 222, pl. 18, figs. 5,6

Remarks: The wall is calcareous and finely perforate. The test is trochospiral, planoconvex and conical in peripheral view. Chambers are crescentic on the spiral side, gradually increasing in size as added. Sutures are curved and depressed on the spiral side. Each chamber is ornamented with a spine except for those of the final whorl. The umbilical side is ornamented with radial striae, separating radial rows of fine granules. The aperture is an interiomarginal and umbilical slit. The test surface is rough.

Family HERONALLENIIDAE Loeblich and Tappan, 1986

Genus HERONALLENIA Chapman and Parr, 1931

Heronallenia lingulata (Burrows and Holland, in Jones 1895)

Figure 23.22-23
1884 Discorbina biconcava Parker and Jones; Brady, p. 653, pl. 91, fig. 3

1895 Discorbina lingulata Burrows and Holland: type reference Jones, 1895, pl. 7, fig. 33

1884 Discorbina biconcava Parker and Jones; Brady, p. 653, pl. 91, fig. 3

1895 Discorbina lingulata Burrows and Holland: type reference Jones 1895, pl. 7, fig. 33

1993 Heronallenia sp. 1; Cimerman and Langer, p. 69 , pl. 73 , figs. $9-10$

1994 Heronallenia lingulata (Burrows and Holland); Jones, p. 96, pl. 91, fig. 3 [cop. Brady, 1884, fig. 3]

2005 Heronallenia lingulata (Burrows and Holland); Rasmussen, p. 96 , pl. 14, figs. 16 , 17

Remarks: The wall is calcareous and finely perforate. The test is very trochospirally coiled, with one to two widening coils, and auriculate in outline. Chambers are crescentic on the spiral side, rapidly increasing in size as added. Chambers are more inflated and ornamented with radial grooves on the umbilical side. Sutures are thickened, elevated and backward curved on the spiral side. The primary aperture is a low interiomarginal and umbilical arch.

Family SIPHONINIDAE Cushman, 1927

Subfamily SIPHONININAE Cushman, 1927 Genus SIPHONINA Reuss, 1850 Siphonina reticulata (Czjzek, 1848)

Figure 23.24-26

1848 Rotalina reticulata Czjzek: p. 145, pl. 8, figs. 7-9

1931 Siphonina reticulata (Czjzek); Cushman, p. 68 , pl. 14, fig. 1

1958 Siphonina reticulata (Czjzek); Parker, p. 273, pl. 4, fig. 25

1988 Siphonina reticulata (Czjzek); Loeblich and Tappan, p. 164, pl. 624, figs. 4-6

1990 Siphonina reticulata (Czjzek); Hasegawa et al., p. 477 , pl. 4, figs. 12-14

1991 Siphonina reticulata (Czjzek); Cimerman and Langer, p. 69, pl. 73, figs. 11-13

1993 Siphonina reticulata (Czjzek); Sgarrella and Moncharmont Zei, p. 222, pl. 19, figs. 7, 8

2004 Siphonina reticulata (Czjzek); Chendes et al., p. 76 , pl. 2, fig. 13 
2005 Siphonina reticulata (Czjzek); Rasmussen, p. 97 , pl. 14, fig. 18

2009 Siphonina reticulata (Czjzek); Avsar et al., p. 135 , pl. 2 , figs. 17,18

Remarks: The wall is calcareous and coarsely and irregularly perforate. The trochospiral test is ovate in outline, lenticular and slightly unequally biconvex in peripheral view. A few subtriangular chambers are visible. Sutures are oblique and thickened on spiral side, radial and slightly depressed on the umbilical side. The periphery is keeled and partly fimbriate. The elliptical aperture, at the base of the final chamber, is on a short neck, and bordered by a lip. The test surface is smooth.

\section{Genus SIPHONINELLA Cushman, 1927 Siphoninella soluta (Brady, 1884) \\ Figure 23.27-28}

1884 Truncatulina soluta Brady: p. 670 , pl. 96, fig. 4

1988 Siphoninella soluta (Brady); Loeblich and Tappan, p. 165, pl. 624, figs. 7-9 [cop. Brady, 1884, fig. 4]

1994 Siphoninella soluta (Brady); Jones, p. 100, pl. 96, fig. 4 [cop. Brady, 1884, fig. 4]

Remarks: The wall is calcareous. The test is trochospirally coiled in the early stage and later uncoiled and uniserial. Sutures are backward curved on the spiral side, radial and depressed on the umbilical side. The periphery is carinate and fimbriate. The slit-like aperture is on a neck and bordered by a rim. The test surface is smooth.

Family DISCORBINELLIDAE Sigal, in Piveteau 1952

Subfamily DISCORBINELLINAE Sigal, in Piveteau 1952

Genus DISCORBINELLA Cushman and Martin, 1935

Discorbinella bertheloti (d'Orbigny, 1839b)

Figure 23.29-30

1839b Rosalina bertheloti d'Orbigny: p. 135, PI. 1 , figs. 28-30

1988 Discorbinella bertheloti (d'Orbigny); Loeblich and Tappan, p. 166, pl. 630, figs. 4-6

1993 Discorbinella bertheloti (d'Orbigny); Hottinger, Halicz and Reiss, p. 114, pl. 150, figs. 1-4

1993 Discorbinella bertheloti (d'Orbigny); Sgarrella and Moncharmont Zei, p. 216, pl. 16, figs. 11,12
2004 Discorbinella bertheloti (d'Orbigny); Chendes et al., p. 76, pl. 3, fig. 3

2005 Discorbinella bertheloti (d'Orbigny); Rasmussen, p. 98, pl. 14, figs. 25, 26

2006 Discorbinella bertheloti (d'Orbigny); Avsar et al., p. 133, pl. 2, fig. 15

2009 Discorbinella bertheloti (d'Orbigny); Avsar et al., p. 135, pl. 2, figs. 19, 20

2009 Discorbinella bertheloti (d'Orbigny); Milker et al., p. 218, pl. 3, figs. 1, 2

Remarks: The wall is calcareous and densely and finely perforate on both sides. The test is ovate in outline, planoconvex and trochospiral. Chambers are low and broad, increasing in size as added. Sutures are backward curved, more thickened and flush with the surface in the early stage on the spiral side, later thinner and depressed on both sides. The umbilical side is flattened, and chambers have an umbilical flap at the base. The periphery is carinate. The aperture is an interiomarginal arch at the periphery and bordered by a lip. The test surface is smooth.

Family PLANULINIDAE Bermudez, 1952 Genus HYALINEA Hofker, 1951a Hyalinea balthica (Schroeter, 1783)

Figure 24.1-2

1783 Nautilus balthicus Schroeter: p. 20, pl. 1, fig. 2

1884 Operculina ammonoides Gronovius, sp., Brady, p. 745, pl. 112, figs. 1, 2

1931 Anomalina balthica (Schroeter); Cushman, p. 108 , pl. 19 , fig. 3

1958 Hyalinea balthica (Schroeter); Parker, p. 275, pl. 4, fig. 39

1960 Hofkerinella baltica (Schroeter); Hofker, p. 255, pl. E, fig. 137

1988 Hyalinea balthica (Schroeter); Loeblich and Tappan, p. 167, pl. 632, figs. 5-8

1993 Hyalinea balthica (Schroeter); Sgarrella and Moncharmont Zei, p. 234, pl. 22, fig. 12

1994 Hyalinea balthica (Schroeter); Jones, p. 110, pl. 112, figs. 1, 2 [cop. Brady, 1884, figs. 1, 2]

2002 Hyalinea balthica (Schroeter); Kaminski et al., p. 174, pl. 3, fig. 13

2003 Hyalinea balthica (Schroeter); Murray, p. 24, fig. 8, no. 8-10 


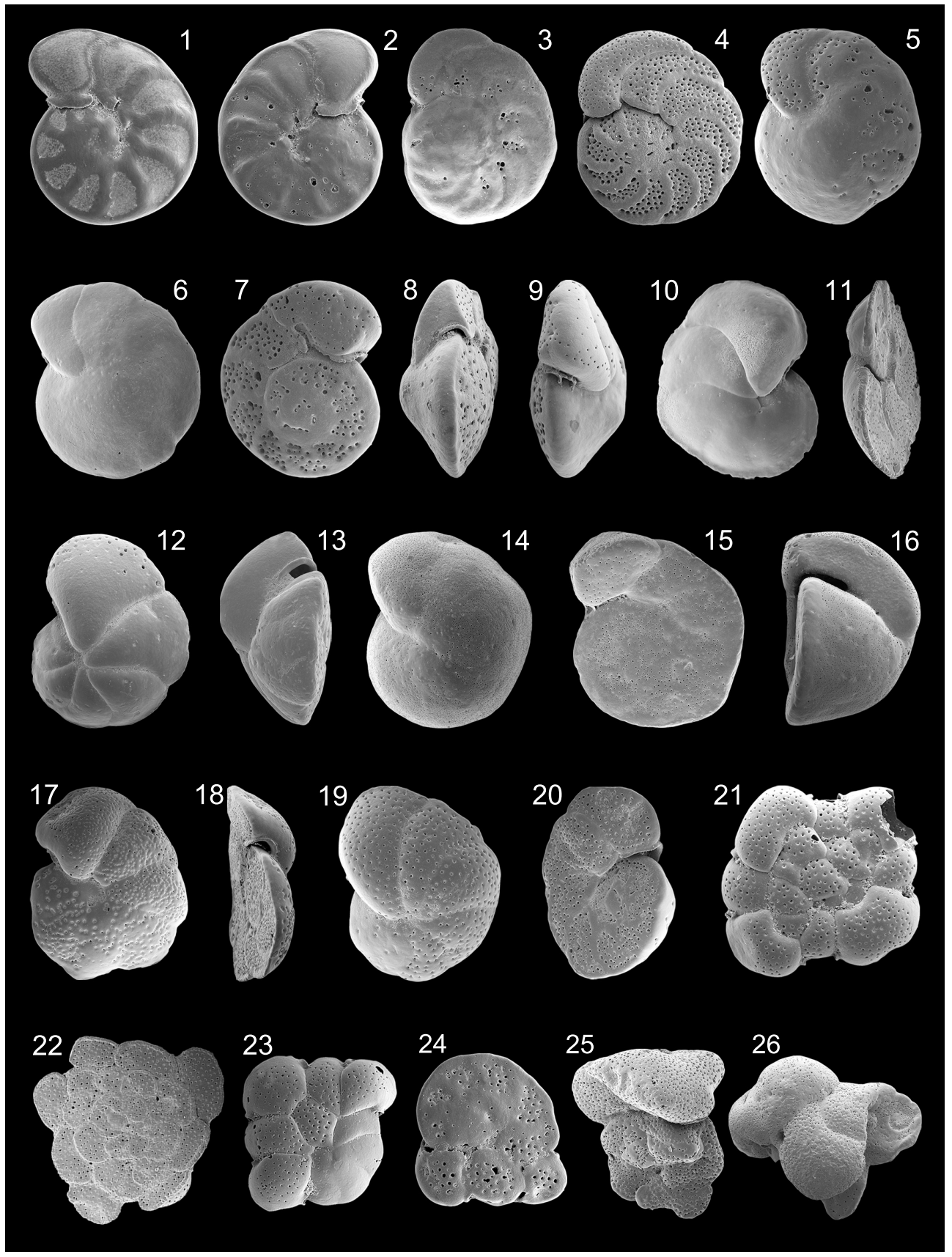

FIGURE 24. 1 Hyalinea balthica (Schroeter), 493x, spiral side; 2 H. balthica (Schroeter), 468x, umbilical side; 3 Planulina ariminensis d'Orbigny, 263x, spiral side; $4 P$. ariminensis d'Orbigny, 257x, umbilical side; 5 Cibicidoides pseudoungerianus (Cushman), 531x, umbilical side; 6 C. pseudoungerianus (Cushman), 394x, umbilical side; 7 C. pseudoungerianus (Cushman), 409x, spiral side; 8 C. pseudoungerianus (Cushman), 373x, peripheral view; 9 C. pseudoungerianus (Cushman), 306x, peripheral view; 10 Cibicides cf. mayori (Cushman), 589x, umbilical side; 11 C. cf. mayori (Cushman), 674x, peripheral view; 12 Cibicides pseudolobatulus Perelis and Reiss, 528x, umbilical side; 13 C. pseudolobatulus Perelis and Reiss, 1060x, peripheral view; 14 Cibicides refulgens de Montfort, 246x, umbilical side; 15 C. refulgens de Montfort, 284x, spiral side; 16 C. refulgens de Montfort, 283x, peripheral view; 17 Lobatula lobatula (Walker and Jacob), 244x, umbilical side; 18 L. lobatula (Walker and Jacob), 184x, peripheral view; 19 L. lobatula (Walker and Jacob), 500x, umbilical side; 20 L. lobatula (Walker and Jacob), 455x, oblique peripheral view; 21 Planorbulina mediterranensis d'Orbigny, 580x, unattached side; 22 P. mediterranensis d'Orbigny, 767x, unattached side; $23 P$. mediterranensis d'Orbigny, 790x, unattached side, juvenile specimen; $24 P$. mediterranensis d'Orbigny, 909x, unattached side, juvenile specimen; 25 Cibicidella variablis (d'Orbigny), 193x, spiral view; 26 C. variablis (d'Orbigny), 314x, umbilical side 
2005 Hyalinea balthica (Schroeter); Rasmussen, p. 98 , pl. 14, figs. 27,28

2006 Hyalinea balthica (Schroeter); Avsar et al., p. 133 , pl. 2, fig. 17

2008 Hyalinea balthica (Schroeter); Abu-Zied et al., p. 52, pl. 2, fig. 30

2009 Hyalinea balthica (Schroeter); Frezza and Carboni, p. 57, pl. 2, fig. 18

Remarks: The wall is calcareous and finely perforate. The test is discoidal in outline, nearly planispiral and slightly evolute on both sides. Up to 12 chambers are visible in the final whorl. Chambers are crescentic and provided with an umbilical flap on the umbilical side. Sutures are backward curved and elevated on both sides. The periphery is angular. The aperture is a low, equatorial and interiomarginal arch, extending as a slit along the spiral sutures on both sides, and bordered by a lip. The test surface is smooth.

Genus PLANULINA d'Orbigny, 1826

Planulina ariminensis d'Orbigny, 1826

Figure 24.3-4

1826 Planulina ariminensis d'Orbigny: p. 280, pl. 14 , figs. 1-3

1985 Planulina ariminensis d'Orbigny; Hermelin and Scott, p. 214, pl. 3, figs. 9-11

1988 Planulina ariminensis d'Orbigny; Loeblich and Tappan, p. 167, pl. 633, figs. 1-4

1990 Planulina ariminensis d'Orbigny; Hasegawa et al., p. 477, pl. 4, figs. 15, 16

1993 Planulina ariminensis d'Orbigny; Sgarrella and Moncharmont Zei, p. 234, pl. 22, fig. 9

2008 Planulina ariminensis d'Orbigny; Abu-Zied et al., p. 52, pl. 2, figs. 31, 32

Remarks: The wall is calcareous and densely perforate on the umbilical side and more loosely perforate on the spiral side. The test is discoidal in outline and low trochospiral. The spiral side is evolute, and the umbilical side is slightly evolute. Chambers are broad and low. Sutures are thickened, elevated, backward curved and imperforate on both sides. The periphery is truncate with a keel. The aperture is an equatorial and interiomarginal slit, extending to the umbilical side, and is bordered by a lip.

Family CIBICIDIDAE Cushman, 1927

Subfamily CIBICIDINAE Cushman, 1927

Genus CIBICIDOIDES Saidova, 1975

Cibicidoides pseudoungerianus (Cushman, 1922b) Figure 24.5-9 1922b Truncatulina pseudoungeriana Cushman: p. 96 , pl. 10, fig. 9

1931 Cibicides pseudoungeriana (Cushman); Cushman, p. 123, pl. 22, fig. 4

1991 Cibicidoides pseudoungerianus (Cushman); Cimerman and Langer, p. 69, pl. 74, figs. 2,3

2005 Cibicides ungerianus (Cushman) "pseudoungerianus type"; Rasmussen, p. 100 , pl. 15, figs. 12,13

2009 Cibicides pseudoungerianus (Cushman); Milker et al., p. 218, pl. 3, fig. 11

2010 Cibicides pseudoungerianus (Cushman); Milker, p. 123, pl. 5, figs. 16, 17

Remarks: The wall is calcareous and densely and coarsely perforate on the spiral side. It is imperforate, loosely coarsely and/ or finely perforate on the umbilical side. The test is slightly biconvex and subcarinate in peripheral view. Sutures are distinct, thickened, radial and curved on the spiral side and can be slightly raised in the early stage. Sutures are oblique on the umbilical side except the final chambers where sutures are depressed. The aperture is an interiomarginal, extraumbilical arch, extending along the base of the last few chambers on the spiral side, and is bordered by a lip. The test surface is smooth. According to the descriptions and illustrations in Cushman (1931) for C. pseudoungerianus and in Rasmussen (2005) for $C$. ungerianus, the test morphology is variable. Our specimens almost resemble some specimens shown as C. pseudoungerianus in Cushman (1931) that show as "pseudoungerianus type" in Rasmussen (2005). Our specimens differ from Cibicidoides pachyderma (Rzehak) due to the thinner carinate periphery and the thinner biconvex test in peripheral view.

Genus CIBICIDES de Montfort, 1808

Cibicides cf. mayori (Cushman, 1924)

Figure 24.10-11

1924 cf. Truncatulina mayori Cushman: p. 39, pl. 12 , figs. 3,4

1965 cf. Cibicides mayori (Cushman); Todd, p. 53 , pl. 22, figs. 3,4

1975 cf. Cibicides(?) mayori (Cushman); Perelis and Reiss, p. 77, pl. 3, figs. 1-7

1993 cf. Cibicides? mayori (Cushman); Hottinger, Halicz and Reiss, p. 116, pl. 152, figs. 1-6 
Remarks: The wall is calcareous and densely perforate on the spiral side. The perforation on the umbilical side is almost restricted to the final chambers. The test is trochospiral and mostly planoconvex. The spiral side is flattened and evolute, the umbilical side in involute and slightly convex. Chambers may be irregularly shaped. The peripheral margin is acute with a thin fringe-like carina. Six to seven chambers are visible in the adult stage. Sutures are backward curved on both sides, limbate on the spiral side and depressed on the umbilical side. On the umbilical side, a small imperforate, umbilical knob may be present. The aperture is an interiomarginal, extraumbilical slit, bordered by a lip.

Cibicides pseudolobatulus Perelis and Reiss, 1975 Figure 24.12-13

1975 Cibicides pseudolobatulus Perelis and Reiss: pp. 77-78, pl. 4, figs. 1-7, pl. 5, figs. 1, 2

1993 Cibicides pseudolobatulus Perelis and Reiss; Hottinger, Halicz and Reiss, p. 116, pl. 152, figs. 7-11

Remarks: The wall is calcareous. The test is trochospiral and slightly concavoconvex with an evolute and flattened spiral side and an involute and convex umbilical side. Chambers increasing in size as added. Six to eight chambers are visible in the adult coil. Sutures are curved and limbate on the spiral side and radiate, curved and depressed on the umbilical side. The peripheral outline is weakly lobulate for the final chambers with an acute carinate peripheral margin. The aperture is a low interiomarginal, extraumbilical and equatorial opening, bordered by a thick rim, and extending into a supplementary spiral aperture, remaining open in the last few chambers of the spiral side. Both sides are perforate, with a coarser perforation on the spiral side and a finer and lesser dense perforation on the umbilical side. The test surface is smooth.

Cibicides refulgens de Montfort, 1808

Figure 24.14-16

1808 Cibicides refulgens de Montfort: p. 123

1931 Cibicides refulgens de Montfort; Cushman, p. 116 , pl. 21 , fig. 2

1988 Cibicides refulgens de Montfort; Loeblich and Tappan, p. 167, pl. 634, figs. 1-3

1991 Cibicides refulgens de Montfort; Cimerman and Langer, p. 70 , pl. 75, figs. 5-9

2003 Cibicides refulgens de Montfort; Murray, p. 21 , fig 7 , no. 1,2
2004 Cibicides refulgens de Montfort; Chendes et al., p. 76, pl. 3, fig. 2

2005 Cibicides refulgens de Montfort; Rasmussen, p. 100 , pl. 15 , figs. 7,8

2009 Cibicides refulgens de Montfort; Milker et al., p. 218, pl. 3, figs. 9, 10

Remarks: The wall is calcareous and finely perforate on both sides. The test is trochospiral and planoconvex with a weak acute and carinate periphery. The umbilical side is convex and the spiral side is flattened to slightly concave. Chambers gradually increasing in size as added. Sutures are backward curved and depressed on the umbilical side, more flush and limbate on the spiral side. The aperture is an interiomarginal, extraumbilical and equatorial opening, extending into a supplementary spiral aperture on the spiral side. The test surface is smooth. Our juvenile specimens resemble those shown by the other authors, while our adult specimens have finer pores on both sides.

Genus LOBATULA Fleming, 1828

Lobatula lobatula (Walker and Jacob, 1798)

Figure 24.17-20

1798 Nautilus lobatulus Walker and Jacob: $p$. 642 , pl. 14 , fig. 36

1846 Truncatulina lobatula d'Orbigny; d'Orbigny, p. 168 , pl. 9 , figs. $18-23$

1931 Cibicides lobatula (Walker and Jacob); Cushman, p. 118, pl. 21, fig. 3

1945 Cibicides lobatulus (Walker and Jacob); Cushman, p. 288, fig. 21

1979 Cibicidoides lobatulus (Walker and Jacob); Corliss, p. 10, pl. 3, figs. 7-9

1987 Cibicides lobatulus (Walker and Jacob); Alberola et al., p. 308, pl. 4, fig. 11

1988 Lobatula lobatula (Walker and Jacob); Loeblich and Tappan, p. 168, pl. 637, figs. 10-13

1991 Lobatula lobatula (Walker and Jacob); Cimerman and Langer, p. 71, pl. 75, figs. $1-4$

1991 Lobatula lobatulus (Walker and Jacob); Wollenburg, p. 63, pl. 19, fig. 3

1993 Lobatula lobatulus (Walker and Jacob); Hottinger, Halicz and Reiss, p. 118, pl. 154, figs. 5-11

1993 Cibicides lobatulus (Walker and Jacob); Sgarrella and Moncharmont Zei, p. 234, pl. 22 , 
figs. 10,11

1994 Cibicides lobatulus (Walker and Jacob); Jones, p. 97, pl. 92, fig. 10; pl. 93, figs. 1 , 4-5

1995 Cibicides lobatulus (Walker and Jacob); Coppa and Di Tuoro, p. 170, pl. 3, figs. 7, 10

2003 Cibicides lobatulus (Walker and Jacob); Murray, p. 21, fig. 6, no. 13-15

2005 Cibicides lobatulus (Walker and Jacob); Rasmussen, p. 99, pl. 15, figs. 4-6

2006 Lobatula lobatula (Walker and Jacob); Avsar et al., p. 133, pl. 3, figs. 1, 2

2008 Cibicides lobatulus (Walker and Jacob); Abu-Zied et al., p. 53, pl. 3, figs. 1, 2

2009 Lobatula lobatula (Walker and Jacob); Frezza and Carboni, p. 55, pl. 1, figs. 1820

2009 Cibicides lobatulus (Walker and Jacob); Milker et al., p. 218, pl. 3, figs. 6-8

2010 Cibicides lobatulus (Walker and Jacob); Milker, p. 122, pl. 5, figs. 14, 15

Remarks: The wall is calcareous with a coarsely and uniformly perforation on both sides. The test is trochospiral and planoconvex with an evolute spiral side and an involute umbilical side and can be irregularly arranged. Chambers increasing in size as added. Sutures are raised and backward curved on the spiral side and radial, curved and depressed on the umbilical side. The peripheral margin is lobulate for the final chambers. The periphery is acute and carinate. The aperture is a low interiomarginal and equatorial opening, bordered by a rim, and continuing into a supplementary spiral opening at the base of the last two to three chambers on the spiral side. The test surface is smooth.

Family PLANORBULINIDAE Schwager, 1877

Subfamily PLANORBULININAE Schwager, 1877

Genus PLANORBULINA d'Orbigny, 1826

Planorbulina mediterranensis d'Orbigny, 1826

Figure 24.21-24

1826 Planorbulina mediterranensis d'Orbigny: $p$. 280 , pl. 15 , figs. $4-6$

1846 Planorbulina mediterranensis d'Orbigny; d'Orbigny, p. 166, pl. 9, figs. 15-17

1931 Planorbulina mediterranensis d'Orbigny; Cushman, p. 129, pl. 24, figs. 5-8

1958 Planorbulina mediterranensis d'Orbigny; Parker, p. 276, pl. 4, fig. 44
1960 Planorbulina mediterranensis d'Orbigny; Hofker, p. 254, pl. E, figs. 128, 129

1988 Planorbulina mediterranensis d'Orbigny; Loeblich and Tappan, p. 170, pl. 645, figs. 1-4

1991 Planorbulina mediterranensis d'Orbigny; Cimerman and Langer, p. 71, pl. 78, figs. 1-8

1993 Planorbulina mediterranensis d'Orbigny; Sgarrella and Moncharmont Zei, p. 235, pl. 23, fig. 4

1995 Planorbulina mediterranensis d'Orbigny; Coppa and Di Tuoro, p. 168, pl. 2, figs. 8, 11

2004 Planorbulina mediterranensis d'Orbigny; Chendes et al., p. 76, pl. 3, fig. 5

2004 Planorbulina mediterranensis d'Orbigny; Mendes et al., p. 178, pl. 1, fig. 5

2005 Planorbulina mediterranensis d'Orbigny; Rasmussen, p. 100, pl. 15, fig. 14

2006 Planorbulina mediterranensis d'Orbigny; Avsar et al., p. 133, pl. 3, fig. 3

2009 Planorbulina mediterranensis d'Orbigny; Avsar et al., p. 135, pl. 3, figs. 2, 3

2009 Planorbulina mediterranensis d'Orbigny; Milker et al., p. 218, pl. 3, fig. 16

Remarks: The wall is calcareous and coarsely and densely perforate on both sides. The test is planoconvex. The early stage is trochospiral and later chambers are cylindrically arranged. Sutures are depressed on the unattached, umbilical side and thickened, limbate and imperforate on the attached, spiral side. The periphery is subangular. In the adult stage, each chamber has two interiomarginal and extraumbilical apertures, bordered by a lip. The test surface is smooth.

Genus CIBICIDELLA Cushman, 1927

Cibicidella variablis (d'Orbigny, 1826)

Figure 24.25-26

1826 Truncatulina variablis d'Orbigny: p. 279, no. 8

1988 Planorbulina variablis (d'Orbigny); Loeblich and Tappan, p. 170, pl. 645, figs. 5, 6

1991 Cibicidella variablis (d'Orbigny); Cimerman and Langer, p. 72 , pl. 77 , figs. 1-10

1993 Cibicidella variablis (d'Orbigny); Sgarrella and Moncharmont Zei, p. 234, pl. 23, figs. 2, 3 


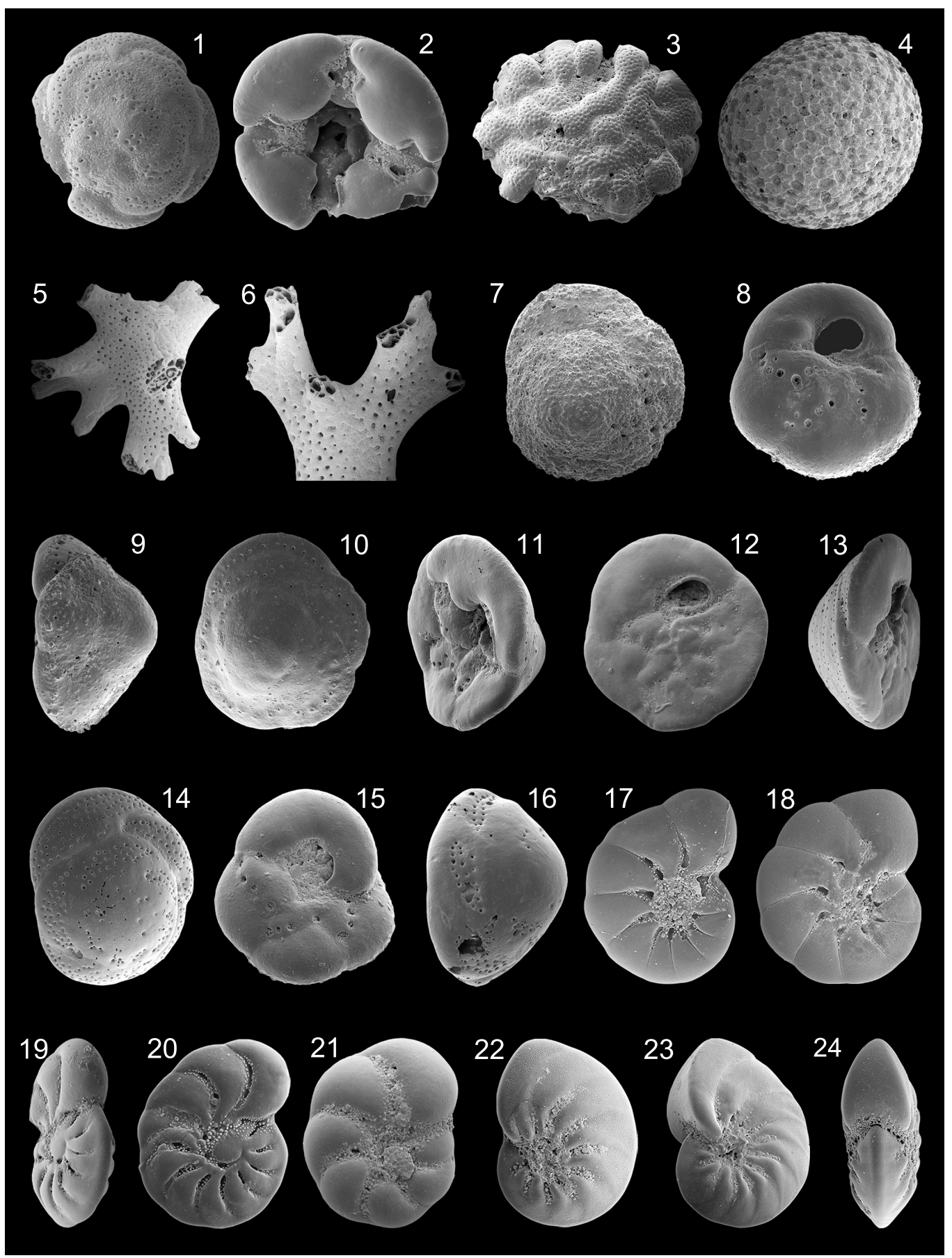

FIGURE 25. 1 Cymbaloporetta bulloides (d'Orbigny), 796x, spiral side; 2 C. bulloides (d'Orbigny), 926x, umbilical side; 3 Acervulina inhaerens Schultze, 386x, unattached side; 4 Sphaerogypsina globula (Reuss), 181x, top view; 5 Miniacina miniacea (Pallas), 56x, side view; 6 M. miniacea (Pallas), 97x, side view; 7 Asterigerinata adriatica Haake, 970x, spiral side; 8 A. adriatica Haake, 1010x, umbilical side; 9 A. adriatica Haake, 1040x, peripheral view; 10 Asterigerinata mamilla (Williamson), 561x, spiral side; 11 A. mamilla (Williamson), 1070x, oblique peripheral view; 12 A. mamilla (Williamson), 427x, umbilical side; 13 A. mamilla (Williamson), 673x, peripheral view; 14 Asterigerinata mariae Sgarrella, 1260x, spiral side; 15 A. mariae Sgarrella, 1440x, peripheral view; 16 A. mariae Sgarrella, 1650x, umbilical side; 17 Haynesina depressula (Walker and Jacob), 683x, side view; $18 \mathrm{H}$. depressula (Walker and Jacob), 680x, side view; 19 Haynesina simplex (Cushman), 500x, oblique peripheral view; $20 \mathrm{H}$. simplex (Cushman), 756x, side view; 21 Haynesina sp. 1, 1170x, side view; 22 Nonion fabum (Fichtel and Moll), 548x, side view; 23 N. fabum (Fichtel and Moll), 489x, side view; 24 N. fabum (Fichtel and Moll), 571x, peripheral view. 
Remarks: The wall is calcareous and coarsely and densely perforate. The test is trochospiral in the early stage and later irregularly arranged. The periphery is subrounded to acute. Sutures are oblique and depressed on the umbilical side, oblique and slightly elevated on the spiral side. In the juvenile stage, specimens have a single aperture. In the adult stage, specimens may have two apertures per chamber, bordered by a rim.

Family CYMBALOPORIDAE Cushman, 1927

Subfamily CYMBALOPORINAE Cushman, 1927

Genus CYMBALOPORETTA Cushman, 1928

Cymbaloporetta bulloides (d'Orbigny, 1839a)

Figure 25.1-2

1839a Rosalina bulloides d'Orbigny: p. 98, pl. 3, figs. $2-5$

1922c Tretomophalus bulloides (d'Orbigny); Cushman, pp. 42-44, text-figs. 2, 3

1988 Cymbaloporetta bulloides (d'Orbigny); Loeblich and Tappan, pp. 170-171, pl. 649, figs. 11-15

1991 Cymbaloporetta sp.1; Cimerman and Langer, p. 72, pl. 80, figs. 1-5

Remarks: The wall is calcareous and is perforate on the spiral side. The test is trochospiral in the early stage and later cylindrical. The spiral side is convex and evolute with depressed and oblique sutures. Early chambers are low, crescentic, slightly inflated, and later chambers are subtriangular with radial sutures. The umbilical side in the benthic stage is concave and involute with inflated, subtriangular and imperforate chambers in the final whorl. The periphery is subacute. The primary apertures are extraumbilical arch-shaped openings, each of them bordered by a rim. Two apertures per chamber are visible in the adult stage. A third opening into the umbilical region, bordered by a rim, is present. The test surface is smooth. In the planktonic stage, a floating chamber is present on the umbilical side.

Family ACERVULINIDAE Schultze, 1854 Genus ACERVULINA Schultze, 1854 Acervulina inhaerens Schultze, 1854

Figure 25.3

1854 Acervulina inhaerens Schultze: p. 68, pl. 6, fig. 12

1931 Acervulina inhaerens Schultze; Cushman, p. 134 , pl. 25 , fig. 2

1988 Acervulina inhaerens Schultze; Loeblich and Tappan, p. 172, pl. 659, figs. 1-6
Remarks: The wall is calcareous and coarsely perforate on both sides. The early stage is coiled and later irregularly arranged. Chambers are inflated, and sutures are oblique and depressed on the unattached side. Sutures are thickened and slightly appressed on the attached side. The apertures are restricted on the coarse perforations on the unattached side. The test surface is smooth.

Genus SPHAEROGYPSINA Galloway, 1933 Sphaerogypsina globula (Reuss, 1848)

Figure 25.4

1848 Ceriopora globula Reuss: p. 33, pl. 5, fig. 7

1988 Sphaerogypsina globula (Reuss); Loeblich and Tappan, p. 173, pl. 662, figs. 4-6

1991 Sphaerogypsina globula (Reuss); Cimerman and Langer, p. 72, pl. 80, figs. 6-9

1993 Sphaerogypsina globula (Reuss); Hottinger, Halicz and Reiss, p. 128, pl. 173, figs. 1-10

1993 Sphaerogypsina globula (Reuss); Sgarrella and Moncharmont Zei, p. 235, pl. 23, fig. 6

Remarks: The wall is calcareous and perforate. The test of these large specimens is mostly spherical and globular. Chambers are small and packed. Septa are raised and imperforate. No primary aperture is present.

Family HOMOTREMATIDAE Cushman, 1927 Genus MINIACINA Galloway, 1933 Miniacina miniacea (Pallas, 1766)

Figure 25.5-6

1766 Millepora miniacea Pallas: p. 251

1884 Polytrema miniaceum Linné; Brady, p. 721, pl. 100, figs. 5-9; pl. 101, fig. 1

1988 Miniacina miniacea (Pallas); Loeblich and Tappan, p. 173, pl. 663, figs. 4-6; pl. 664, figs. 1-5

1991 Miniacina miniacea (Pallas); Cimerman and Langer, p. 73, pl. 81, figs. 1-6

1993 Miniacina miniacea (Pallas); Hottinger, Halicz and Reiss, p. 122, pl. 175, figs. 9, 10; pl. 176, figs. 1-6; pl. 177, figs. 1-7

1993 Miniacina miniacea (Pallas); Sgarrella and Moncharmont Zei, p. 235, pl. 23, fig. 5

1994 Miniacina miniacea (Pallas); Jones, p. 101, pl. 100, figs. 5-9; pl. 101, fig. 1 [cop. Brady, 1884, figs. 5-9; fig. 1] 
Remarks: The wall is calcareous and densely and finely perforate. The pink to red test is large, arborescent and attached. The apertures are on the end of the branches and are bordered by a lip. The test surface is pock-marked.

Family ASTERIGERINATIDAE Reiss, 1963 Genus ASTERIGERINATA Bermudez, 1949 Asterigerinata adriatica Haake, 1977

Figure 25.7-9

1977 Asterigerinata adriatica Haake: p. 69, pl. 3, fig. 1-5

1991 Asterigerinata sp. 1; Cimerman and Langer, p. 73, pl. 82, figs. 5, 6

1993 Asterigerinata adriatica Haake; Sgarrella and Moncharmont Zei, p. 224, pl. 19, figs. 11,12

2004 Asterigerinata adriatica Haake; Chendes et al., p. 76, pl. 3, fig. 6

2006 Asterigerinata adriatica Haake; Avsar et al., p. 133, pl. 3, fig. 4

Remarks: The wall is calcareous. The test is low trochospiral and conical in peripheral view. The spiral side is convex and evolute. The umbilical side is flattened and involute. Chambers gradually increasing in size as added on the spiral side. The final chamber occupies approximately one third of the periphery. Sutures are curved, oblique, thickened, imperforate and slightly depressed on the spiral side. On the umbilical side, sutures are curved, oblique and slightly depressed. The periphery is subacute. The aperture is a low interiomarginal, umbilical arch at the base of the final chamber. The test surface is densely ornamented with pustules and pseudospines on the spiral side. Both sides are loosely perforate with larger pores.

Asterigerinata mamilla (Williamson, 1858)

Figure 25.10-13

1858 Rotalina mamilla Williamson: p. 54, pl. 4, figs. 109-111

1931 Discorbis mamilla (Williamson); Cushman, p. 23, pl. 5, fig. 1 [cop. Williamson, 1858, figs. 109-111]

1958 Asterigerinata mamilla (Williamson); Parker, p. 264, pl. 3, figs. 5, 6

1960 Asterigerinata mamilla (Williamson); Hofker, p. 252, pl. D, fig. 111

1987 Asterigerinata mamilla (Williamson); Alberola et al., p. 322, pl. 4, fig. 10
1987 Asterigerinata mamilla (Williamson); Jorissen, p. 41, pl. 3, fig. 1

1991 Asterigerinata mamilla (Williamson); Cimerman and Langer, p. 73, pl. 82, figs. 1-4

1993 Asterigerinata mamilla (Williamson); Sgarrella and Moncharmont Zei, p. 224, pl. 19, figs. 9, 10

1995 Asterigerinata mamilla (Williamson); Coppa and Di Tuoro, p. 170, pl. 3, figs. 11, 12

2004 Asterigerinata mamilla (Williamson); Mendes et al., p. 178, pl. 1, fig. 2

2005 Asterigerinata mamilla (Williamson); Rasmussen, p. 101, pl. 15, figs. 17, 18

2006 Asterigerinata mamilla (Williamson); Avsar et al., p. 133, pl. 3, figs. 5-7

2008 Asterigerinata mamilla (Williamson); AbuZied et al., p. 53, pl. 3, figs. 1, 2

2009 Asterigerinata mamilla (Williamson); Milker et al., p. 218 , pl. 3 , figs. $13-15$

Remarks: The wall is calcareous. The test is low trochospiral and conical in peripheral view. The spiral side is convex and evolute. The umbilical side is involute. Chambers rapidly increase in breadth as added on the spiral side. The final chamber occupies approximately one third of the periphery. Sutures are curved, oblique, thickened, imperforate and flush with the surface on the spiral side. On the umbilical side, sutures are curved, oblique and slightly depressed. The periphery is acutely carinate. The aperture is a low interiomarginal, umbilical arch at the base of the final chamber. Both sides are perforate - with larger pores on the chamber margins of the spiral side and more loosely larger and irregularly arranged pores on the umbilical side. The test surface is smooth.

$$
\begin{gathered}
\text { Asterigerinata mariae Sgarrella, } \\
\text { in Amore et al. } 1990 \\
\text { Figure 25.14-16 }
\end{gathered}
$$

1990 Asterigerinata mariae Sgarrella, type reference: Amore et al., 1990, pp. 477-478, pl. 3, figs. 1-8

1993 Asterigerinata mariae Sgarrella; Sgarrella and Moncharmont Zei, p. 224, pl. 20, fig. 1

2004 Asterigerinata mariae Sgarrella; Fiorini, p. 50, pl. 1, figs. $16-18$

2009 Asterigerinata mariae Sgarrella; Milker et al., p. 218 , pl. 3 , figs. $21-23$ 
Remarks: The wall is calcareous. The test is low trochospiral and conical in peripheral view. The spiral side is convex and evolute. The umbilical side is involute, flattened to slightly concave. Chambers gradually increasing in size as added on the spiral side. Sutures are curved, oblique, thickened, imperforate and depressed on the spiral side. On the umbilical side, sutures are curved, oblique and depressed. The periphery is subacute. The aperture is a low interiomarginal, umbilical arch at the base of the final chamber. Both sides are perforate - with larger and denser pores on the spiral side and more loosely, larger and irregularly arranged pores on the umbilical side. The test surface is smooth.

Family NONIONIDAE Schultze, 1854

Subfamily NONIONINAE Schultze, 1854

Genus HAYNESINA Banner and Culver, 1978

Haynesina depressula (Walker and Jacob, 1798)

Figure 25.17-18

1798 Nautilus depressulus Walker and Jacob: $p$. 641 , pl. 14, fig. 33

1914 Nonionina depressula (Walker and Jacob); Cushman, p. 23, pl. 17, fig. 3

1987 Nonion depressulum (Walker and Jacob); Jorissen, p. 39, pl. 2, fig. 7

1991 Haynesina depressula (Walker and Jacob); Cimerman and Langer, p. 81, pl. 83, figs. 1-4

1993 Nonion depressulum (Walker and Jacob); Sgarrella and Moncharmont Zei, p. 238, pl. 24, figs. 3, 4

2004 Haynesina depressula (Walker and Jacob); Chendes et al., p. 76, pl. 3, fig. 7

2005 Haynesina depressula (Walker and Jacob); Rasmussen, p. 102, pl. 16, fig. 3

2009 Nonion depressulum (Walker and Jacob); Avsar et al., p. 135, pl. 3, figs. 7, 8

Remarks: The wall is calcareous and is finely and densely perforate. The test is planispiral, circular in outline, and biumbilicate with narrow and depressed umbilici in peripheral view. Up to 12 inflated chambers are visible in the final whorl, gradually increasing in size as added. The sutures are radial, backward curved and deeply incised near the umbilicus. The umbilical region is filled with pustules. The periphery is subrounded. The aperture is an interiomarginal arch, obscured by pustules. The test surface is smooth.
Haynesina simplex (Cushman, 1933c)

Figure 25.19-20

1933c Elphidium simplex Cushman: p. 52, pl. 12, figs. 8, 9

1991 Haynesina sp. 2; Cimerman and Langer, p. 82, pl. 83, figs. 9, 10

2005 Haynesina depressulum simplex (Cushman); Debenay et al., p. 336, pl. 3, fig. 16

2010 Haynesina sp. 2; Milker, p. 125, pl. 6, fig. 8

Remarks: The wall is calcareous and finely perforate. The test is planispiral, circular in outline and very compressed in peripheral view. Up to 12 narrow chambers are visible in the final whorl, slightly increasing in size as added. The umbilical region is partly filled with pustules, and an umbilical knob is present. The deeply incised sutures are backward curved and ornamented with pustules. The periphery is subangular. The aperture is an interiomarginal opening, obscured by pustules. The test surface is smooth.

\section{Haynesina sp. 1}

Figure 25.21

Remarks: The wall is calcareous, finely and densely perforate. The test is planispiral, circular in outline and biumbilicate in peripheral view. The umbilical region is depressed and completely filled with pustules. Sutures are backward curved and depressed. Seven to eight slightly inflated chambers are visible in the final whorl. Chambers slightly increasing in size as added. The periphery is subrounded. The aperture is a low interiomarginal arch at the base of the apertural face, obscured by pustules. The test surface is smooth.

Genus NONION de Montfort, 1808

Nonion fabum (Fichtel and Moll, 1798)

Figure 25.22-24

1798 Nautilus faba Fichtel and Moll: p. 103, pl. $19 \mathrm{~b}, \mathrm{c}$

1884 Nonionina boueana d'Orbigny; Brady, p. 729 , pl. 109, figs. 12,13

1988 Nonion fabum (Fichtel and Moll); Loeblich and Tappan, p. 179, pl. 690, figs. 1-7

1994 Nonion fabum (Fichtel and Moll); Jones, $p$. 108, pl. 109, figs. 12, 13 [cop. Brady, 1884, figs. 12, 13]

2004 Nonion fabum (Fichtel and Moll); Mendes et al., p. 178. pl. 1, fig. 10

2005 Nonion fabum (Fichtel and Moll); Rasmussen, p. 102, pl. 16, fig. 5 
2008 Nonion asterizans (Fichtel and Moll); Leiter, p. 46, pl. 2, fig. 5

Remarks: The wall is calcareous and finely and densely perforate. The test is planispiral and biumbilicate with slightly depressed umbilici. The coiling is involute. The test is ovate in outline and compressed in peripheral view. Chambers are narrow and numerous, rapidly increasing in breadth as added. Sutures are thickened and backward curved, flush with the surface near the periphery and depressed near the umbilici. The periphery is carinate. The aperture is an interiomarginal slit, extending to the umbilici and is ornamented with pustules. The umbilici are ornamented with pustules. The test surface is smooth.

Genus NONIONELLA Cushman, 1926

Nonionella turgida (Williamson, 1858)

Figure 26.1-6

1858 Rotalina turgida Williamson: p. 50, pl. 4, figs. 95-97

1884 Nonionina turgida (Williamson); Brady, p. 731, pl. 109, figs. $17-19$

1914 Nonionina turgida (Williamson); Cushman, p. 29 , pl. 15 , fig. 3 [cop. Brady, 1884, fig. 17]

1930a Nonionella turgida (Williamson); Cushman, p. 15, pl. 6, figs. 1-4 [fig.1: cop. Williamson, 1858, figs. 95-97; fig. 2: cop. Brady, 1884, figs. 17, 18]

1960 Nonionella turgida (Williamson); Hofker, p. 258, pl. F, figs. 181, 182

1987 Nonionella turgida (Williamson); Jorissen, p. 47 , pl. 4 , figs. $11-13$

1993 Nonionella turgida (Williamson); Sgarrella and Moncharmont Zei, p. 240, pl. 24, fig. 5

1991 Nonionella turgida (Williamson); Cimerman and Langer, p. 74, pl. 84, figs. 6-8

1994 Nonionella turgida (Williamson); Jones, p. 108, pl. 109, figs. 17-19 [cop. Brady, 1884, figs. 17-19]

2003 Nonionella turgida (Williamson); Murray, p. 24 , fig. 9 , no. 4,5

2004 Nonionella turgida (Williamson); Fiorini, p. 50, pl. 1, fig. 13

2005 Nonionella turgida (Williamson); Rasmussen, p. 103, pl. 16, figs. 11, 12

2006 Nonionella turgida (Williamson); Avsar et al., p. 133 , pl. 3, fig. 8
2008 Nonionella turgida (Williamson); Abu-Zied et al., p. 53, pl. 3, figs. 12, 13

2009 Nonionella turgida (Williamson); Frezza and Carboni, p. 57, pl. 2, figs. 7, 8

2010 Nonionella sp. 1; Milker, p. 126, pl. 6, fig. 12

Remarks: The wall is calcareous and finely and densely perforate. The test is very low trochospiral, slightly compressed in peripheral view and ovate in outline. The peripheral margin is subrounded. Chambers rapidly increasing in length as added in the final whorl. A flap-like projection is visible, situated on one side or is bilaterally placed and may have a fist-like extension. The aperture is an interiomarginal and equatorial arch. The test surface is smooth.

Subfamily ASTRONONIONINAE Saidova, 1981 Genus ASTRONONION Cushman and Edwards, 1937

Astrononion stelligerum (d'Orbigny, 1839b)

Figure 26.7-8

1839b Nonionina stelligera d'Orbigny: p. 128, pl. 3 , figs. 1,2

1884 Nonionina stelligera d'Orbigny; Brady, p. 728, pl. 109, figs. 3, 4

1930a Nonion stelligerum (d'Orbigny); Cushman, p. 7, pl. 2, figs. 8-12; pl. 3, figs. 1-3 [fig. 8: cop. Brady, 1839b; fig. 11: cop. Brady, 1884, fig. 3]

1958 Astrononion stelligerum (d'Orbigny); Parker, p. 258, pl. 1, figs. 34, 35

1988 Astrononion stelligerum (d'Orbigny); Loeblich and Tappan, p. 180, pl. 694, figs. 1, 2; figs. 20, 21

1990 Astrononion stelligerum (d'Orbigny); Sprovieri and Hasegawa, p. 457, pl. 3, figs. 1, 2

1991 Astrononion stelligerum (d'Orbigny); Cimerman and Langer, p. 74, pl. 84, figs. 13-15

1993 Astrononion stelligerum (d'Orbigny); Sgarrella and Moncharmont Zei, p. 238, pl. 24, fig. 10

1994 Astrononion stelligerum (d'Orbigny); Jones, p. 107, pl. 109, figs. 3, 4 [cop. Brady, 1884, figs. 3, 4]

2006 Astrononion stelligerum (d'Orbigny); Avsar et al., p. 133, pl. 3, figs. 9, 10 


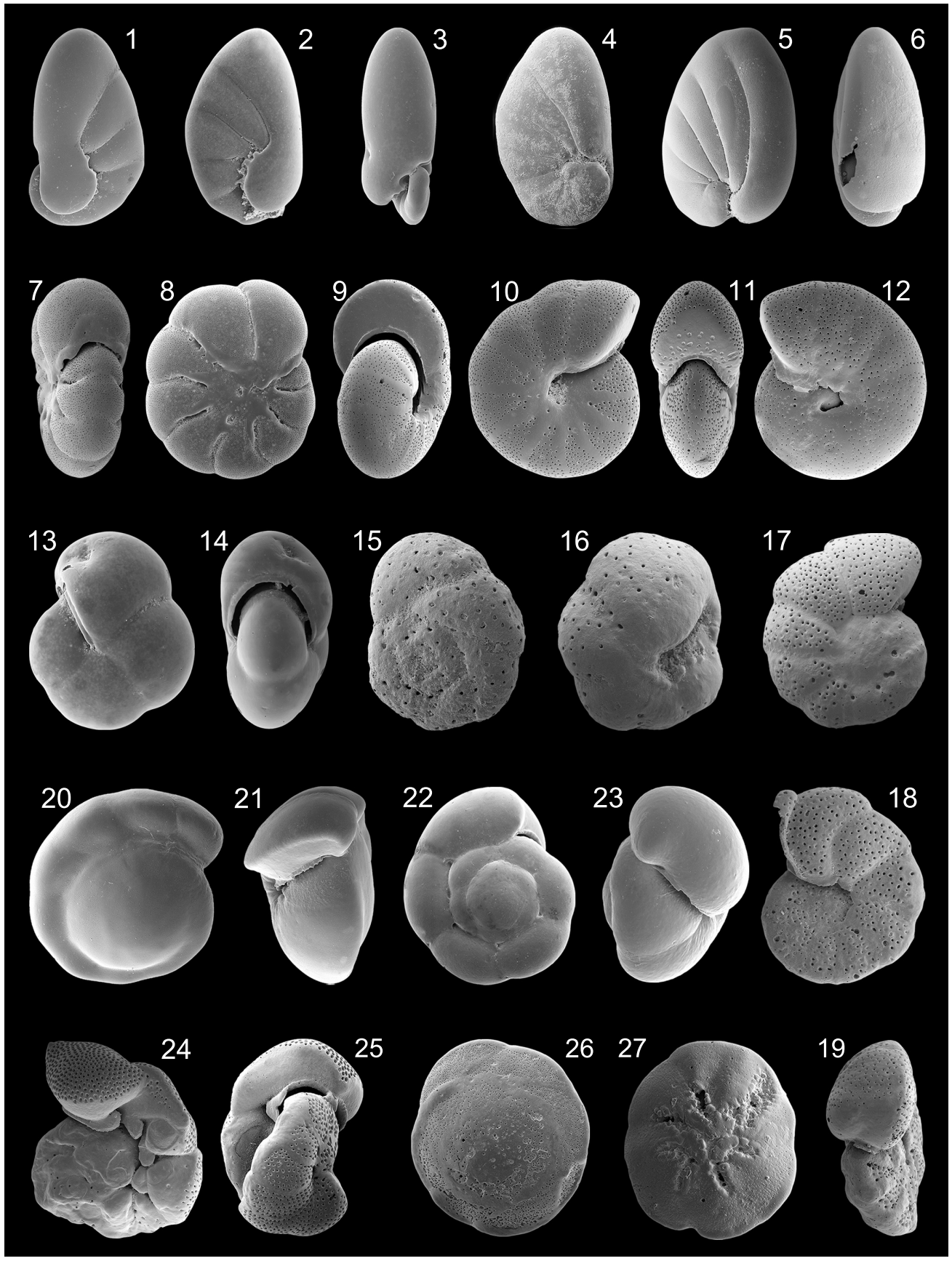

FIGURE 26. 1 Nonionella turgida (Williamson), 852x, side view; 2 N. turgida (Williamson), 493x, side view; 3 N. turgida (Williamson), 1020x, face view; 4 N. turgida (Williamson), 811x, side view; 5 N. turgida (Williamson), 739x, side view; 6 N. turgida (Williamson), 620x, face view; 7 Astrononion stelligerum (d'Orbigny), 350x, peripheral view; 8 A. stelligerum (d'Orbigny), 372x, side view; 9 Melonis affinis (Reuss), 454x, apertural view; 10 M. affinis (Reuss), 446x, side view; 11 Melonis barleeanum (Williamson), 597x, apertural view; 12 M. barleeanum (Williamson), 538x, side view; 13 Pullenia quadriloba Reuss, 598x, side view; 14 P. quadriloba (Reuss), 552x, peripheral view; 15 Svratkina sp. 1, 988x, spiral side; 16 Svratkina sp. 1, 981x, umbilical side; 17 Anomalinoides sp. 1, 298x, umbilical side; 18 Anomalinoides sp. 1, 314x, spiral side; 19 Anomalinoides sp. 1, 272x, peripheral view; 20 Gyroidinoides soldanii (d'Orbigny), 409x, spiral side; 21 G. soldanii (d'Orbigny), 624x, peripheral view; 22 Gyroidinoides umbonata (Silvestri), 549x, spiral side; 23 G. umbonata (Silvestri), 776x, peripheral view; 24 Discanomalina semipunctata (Bailey), 230x, umbilical side; 25 D. semipunctata (Bailey), 234x, peripheral view; 26 Buccella granulata (Di Napoli Alliata), 423x, spiral side; 27 B. granulata (Di Napoli Alliata), 377x, umbilical side. 
2009 Astrononion stelligerum (d'Orbigny); Avsar et al., p. 135, pl. 3, fig. 9

Remarks: The wall is calcareous and finely and densely perforate. The test is planispirally enrolled, biumbilicate and involute. It is circular in lateral view and compressed in peripheral view. Chambers are inflated, gradually increasing in size as added, and have a triangular, imperforate plate, extending from the umbilicus toward the preceding chamber. Sutures are incised and gently backward curved. The periphery is subrounded. The aperture is a broad and low interiomarginal and equatorial arch, bordered by a rim, and extending into the umbilical region. The test surface is smooth.

\section{Subfamily PULLENIINAE Schwager, 1877 Genus MELONIS de Montfort, 1808 Melonis affinis (Reuss, 1851) Figure 26.9-10}

1851 Nonionina affinis Reuss: p. 72, pl. 5, fig. 32 1884 Nonionina umbilicatula Montagu; Brady, p. 726, pl. 109, figs. 8, 9

1978 Nonion affine (Reuss); Boltovskoy, p. 162, pl. 5, figs. 1, 2

1990 Melonis affinis (Reuss); Sprovieri and Hasegawa, p. 457, pl. 3, figs. 11, 12

1994 Melonis affinis (Reuss); Jones, p. 107, pl. 109, figs. 8, 9 [cop. Brady, 1884, figs. 8, 9]

2008 Melonis affinis (Reuss); Abu-Zied et al., p. 53, pl. 3, figs. 14, 15

2009 Melonis pompilioides (Fichtel and Moll); Avsar et al., p. 135, pl. 3, figs. 10, 11

2009 Melonis affinis (Reuss); Milker et al., p. 218 , pl. 3 , fig. 20

Remarks: The wall is calcareous and densely perforate except for the apertural face and the rim and the sutures. The test is planispirally enrolled, involute and biumbilicate, with depressed umbilici. Chambers gradually increasing in size but rapidly in thickness as added in the final whorl, resulting in a broader apertural face when compared to Melonis barleeanum. Sutures are thickened, radial and gently curved and slightly raised in the early stage. The periphery is rounded. The aperture is an interiomarginal and equatorial arch, extending into the umbilical region, and is bordered by a relatively thick rim.

Melonis barleeanum (Williamson, 1858)

Figure 26.11-12

1858 Nonionina barleeana Williamson: p. 32, pl. 3 , figs. 68,69 1930a Nonion barleeanum (Williamson); Cushman, p. 11, pl. 4, fig. 5 [cop. Williamson, 1858, figs. 68, 69]

1958 Nonion barleeanum (Williamson); Parker, p. 258 , pl. 1, figs. 36,37

1958 Nonion barleeanum (Williamson); Todd, p. 190, pl. 1, fig. 7

1979 Melonis barleeanum (Williamson); Corliss, p. 10 , pl. 5 , figs. 7,8

1987 Nonion barleeanum (Williamson); Jorissen, p. 43 , pl. 4 , fig. 8

1988 Melonis barleeanum (Williamson); Loeblich and Tappan, p. 180, pl. 696, figs. 5, 6

1990 Melonis barleeanum (Williamson); Sprovieri and Hasegawa, p. 457, pl. 3, figs. 7, 8

1991 Nonion barleeanum (Williamson); Rasmussen, p. 364 , fig. 7 , no. 10

1993 Melonis barleeanum (Williamson); Sgarrella and Moncharmont Zei, p. 242, pl. 26, figs. 1, 2

2003 Melonis barleeanum (Williamson); Sen Gupta, p. 191, text-fig. 11.5, no. 6

2004 Melonis barleeanum (Williamson); Chendes et al., p. 76, pl. 4, fig. 1

2008 Melonis barleeanum (Williamson); AbuZied et al., p. 53, pl. 3, figs. 16, 17

2009 Melonis barleeanum (Williamson); Milker et al., p. 218 , pl. 3 , fig. 24

Remarks: The wall is calcareous and densely perforate except for the apertural face and the rim and the sutures. The test is planispirally enrolled, involute and biumbilicate, with depressed umbilici. Chambers gradually increasing in size as added in the final whorl. Sutures are thickened, radial, gently curved and flush with the surface. The periphery is rounded. The aperture is an interiomarginal, equatorial arch, extending into the umbilical region, and is bordered by a thin rim.

Genus PULLENIA Parker and Jones, in Carpenter, Parker and Jones 1862

Pullenia quadriloba Reuss, 1867

Figure 26.13-14

1867 Pullenia compressiuscula Reuss var. quadriloba Reuss: p. 87, pl. 3, fig. 8

1951 Pullenia quadriloba Reuss; Cushman and Stainforth, p. 161 , pl. 28, fig. 5

1978 Pullenia quadriloba Reuss; Boltovskoy, p. 166, pl. 6, fig. 20 
1990 Pullenia quadriloba Reuss; Sprovieri and Hasegawa, p. 457, pl. 3, figs. 19, 20

Remarks: The wall is calcareous. The test is planispirally enrolled, involute and compressed in peripheral view. Four moderate inflated chambers are visible. Sutures are radial and depressed. The aperture is an interiomarginal, crescentic slit, extending into the umbilical region, and is bordered by a lip. The test surface is smooth.

Family ALABAMINIDAE Hofker, 1951a Genus SVRATKINA Pokorny, 1956 Svratkina sp. 1

Figure 26.15-16

Remarks: The wall is calcareous and coarsely perforate on both sides with a denser perforation on the spiral side and less dense perforation on the umbilical side. The test is trochospirally enrolled, unequally biconvex and ovate in outline. The spiral side is evolute and rather flattened. Six crescentic chambers are visible in the final whorl on the spiral side, increasing in size as added. Sutures are oblique, curved and depressed on the spiral side. The umbilical side is involute and convex with nearly radial and slightly depressed sutures. The periphery is rounded. The aperture is an elongate, oblique opening in a slight depression, extending from near the umbilicus to the face of the final chamber. The test surface is smooth.

\section{Family HETEROLEPIDAE Gonzales-Donoso, 1969}

Genus ANOMALINOIDES Brotzen, 1942 Anomalinoides sp. 1

Figure 26.17-19

Remarks: The wall is calcareous and coarsely and densely perforate. The test is low trochospirally enrolled and subcircular in outline. The spiral side is evolute with inflated chambers, increasing in size as added. Sutures on the spiral side are backward curved, thickened and slightly elevated in the early stage and later depressed. The umbilical side is involute and provided with a knob-like feature in the umbilical region. Sutures are radial, slightly curved and depressed on the umbilical side. The peripheral outline is lobulate. The aperture is a low interiomarginal arch, extending toward the spiral side along the spiral suture beneath the umbilical margin of the last few chambers, and is bordered by a lip. The test surface is smooth.

Family GAVELINELLIDAE Hofker, 1956 Subfamily GYROIDINOIDINAE Saidova, 1981

Genus GYROIDINIODES Brotzen, 1842
Gyroidinoides soldanii (d'Orbigny, 1826)

Figure 26.20-21

1826 Gyroidina soldanii d'Orbigny: p. 278, no. 5

1884 Rotalia soldanii (d'Orbigny); Brady, p. 706, pl. 107, figs. 6,7

1931 Gyroidina soldanii (d'Orbigny); Cushman, p. 38 , pl. 8, figs. 3-8

1965 Gyroidina soldanii (d'Orbigny); Todd, p. 19, pl. 6 , fig. 4

1968 Gyroidina neosoldanii Brotzen; Roegl, p. 102, pl. 4, fig. 13a-c

1993 Gyroidina neosoldanii Brotzen; Sgarrella and Moncharmont Zei, p. 241, pl. 25, figs. 5,6

1994 Gyrodoidiniodes soldanii (d'Orbigny); Jones, p. 106, pl. 107, figs. 6, 7 [cop. Brady, 1884, figs. 6, 7]

2010 Gyroidina neosoldanii Brotzen; Milker, p. 127 , pl. 6 , figs. 20,21

Remarks: The wall is calcareous and densely and finely perforate. The test is trochospirally enrolled, with an evolute and flattened spiral side and a strongly convex umbilical side. Chambers gradually increasing in size as added in the final whorl. Sutures are backward curved, flush with the surface on the umbilical side and depressed in the final whorl on the spiral side. The aperture is an interiomarginal, umbilical slit, extending toward the periphery, and is bordered by a lip. The test surface is smooth.

Gyroidinoides umbonata (Silvestri, 1898)

Figure 26.22-23

1898 Rotalia soldanii d'Orbigny var. umbonata Silvestri: p. 329, pl. 6, fig. 14

1958 Gyroidina umbonata (Silvestri); Parker, p. 266, pl. 3, figs. 19, 20

1958 Gyroidina umbonata (Silvestri); Todd, p. 197, pl. 1, fig. 18

1992 Gyroidina umbonata (Silvestri); Schiebel, p. 48 , pl. 4 , fig. 8

1993 Gyroidina umbonata (Silvestri); Sgarrella and Moncharmont Zei, p. 241, pl. 25, figs. 1,2

2005 Gyroidinoides umbonata (Silvestri); Rasmussen, p. 106, pl. 17, figs. 9-11

2010 Gyroidina umbonata (Silvestri); Milker, p. 127, pl. 6, figs. 18,19 
Remarks: The wall is calcareous and densely and finely perforate. The test is trochospirally enrolled, with a slightly evolute spiral side and a strongly convex umbilical side. The inflated chambers rapidly increasing in size as added. Sutures are nearly radial, curved and depressed on both sides. The primary aperture is an interiomarginal and umbilical slit, extending toward the periphery, and is bordered by a relatively thick lip. Secondary openings are present at the base of the later chambers on the spiral side. The test surface is smooth.

Subfamily GAVELINELLINAE Hofker, 1956

Genus DISCANOMALINA Asano, 1951

Discanomalina semipunctata (Bailey, 1851)

Figure 26.24-25

1851 Rotalina semipunctata Bailey: p. 11, figs. 17-19

1978 Discanomalina semipunctata (Bailey); Medioli and Scott, p. 296, pl. 1, figs. 13-16

1980 Paromalina semipunctata (Bailey); Hofker, p. 65 , fig. $18 \mathrm{e}-\mathrm{h}$

1985 Discanomalina semipunctata (Bailey); Hermelin and Scott, p. 206, pl. 6, figs. 3, 4

1988 Discanomalina semipunctata (Bailey); Loeblich and Tappan, p. 185, pl. 718, figs. 1-9

Remarks: The wall is calcareous, coarsely perforate on the unattached side and nearly imperforate on the attached side and the apertural face. The test is low trochospiral and involute with an irregular growth. Chambers are inflated and have triangular flaps on the attached side. Sutures are curved, depressed on the attached side and flush with the surface on the unattached side. The primary aperture is a broad and low equatorial arch, extending into the umbilicus, and is bordered by a lip. Secondary openings are present beneath the umbilical flaps.

Family TRICHOHYALIDAE Saidova, 1981 Genus BUCCELLA Andersen, 1952

Buccella granulata (Di Napoli Alliata, 1952) Figure 26.26-27

1952 Eponidus frigidus (Cushman) var. granulatus Di Napoli Alliata: p. 103, pl. 5, fig. 3

1987 Buccella granulata (Di Napoli Alliata); Alberola et al., p. 308, pl. 4, fig. 15

1987 Buccella granulata (Di Napoli Alliata); Jorissen, p. 41, pl. 3, fig. 5

1993 Buccella granulata (Di Napoli Alliata); Sgarrella and Moncharmont Zei, p. 216, pl. 16, figs. 6,7
1995 Buccella granulata (Di Napoli Alliata); Coppa and Di Tuoro, p. 168, pl. 2, figs. 7 , 14

2004 Buccella granulata (Di Napoli Alliata); Fiorini, p. 52, pl. 2, figs. 1-3

2005 Buccella granulata (Di Napoli Alliata); Rasmussen, p. 107, pl. 18, figs. 1-3

2009 Buccella granulata (Di Napoli Alliata); Milker et al., p. 218, pl. 3, figs. 12, 13

Remarks: The wall is calcareous and densely perforate on both sides except for the sutures on the spiral side and the periphery. The test is trochospirally enrolled and planoconvex. Three to four whorls are visible with seven to eight chambers in the final whorl. Sutures are thickened, oblique and slightly elevated on the spiral side, nearly radial and depressed to deeply incised on the umbilical side. The periphery is carinate. The aperture is an interiomarginal opening midway between the umbilicus and the periphery, and is covered by umbilical pustules. The test is ornamented with granules in the umbilical region. The test surface is smooth.

Family ROTALIIDAE Ehrenberg, 1839

Subfamily AMMONIINAE Saidova, 1981

Genus AMMONIA Bruennich, 1772

Ammonia beccarii (Linné, 1758)

Figure 27.1-2

1758 Nautilus beccarii Linné: p. 710

1858 Rotalina beccarii Williamson: p. 48, pl. 4, figs. 90-92

1931 Rotalia beccarii (Linné); Cushman, p. 58, pl. 12, figs. 1-7; pl. 13, figs. 1, 2

1960 Streblus beccarii (Linné); Hofker, p. 255, pl. E, fig. 134

2005 Ammonia beccarii (Linné); Debenay et al., p. 334, pl. 2, fig. 17

2009 Ammonia beccarii (Linné); Frezza and Carboni, p. 55, pl. 1, figs. 5, 12

Remarks: The wall is calcareous and finely and densely perforate on both sides. The test is low trochospirally enrolled and biconvex, with an evolute spiral and an involute umbilical side. Chambers are inflated and subglobular. Sutures are deeply incised and nearly radial and curved on the umbilical side. In the umbilical region, an umbilical plug is present, surrounded by pustules. Sutures on the spiral side are radial and curved, thickened and imperforate, slightly raised to depressed in the early part and later incised. The aperture is an inte- 


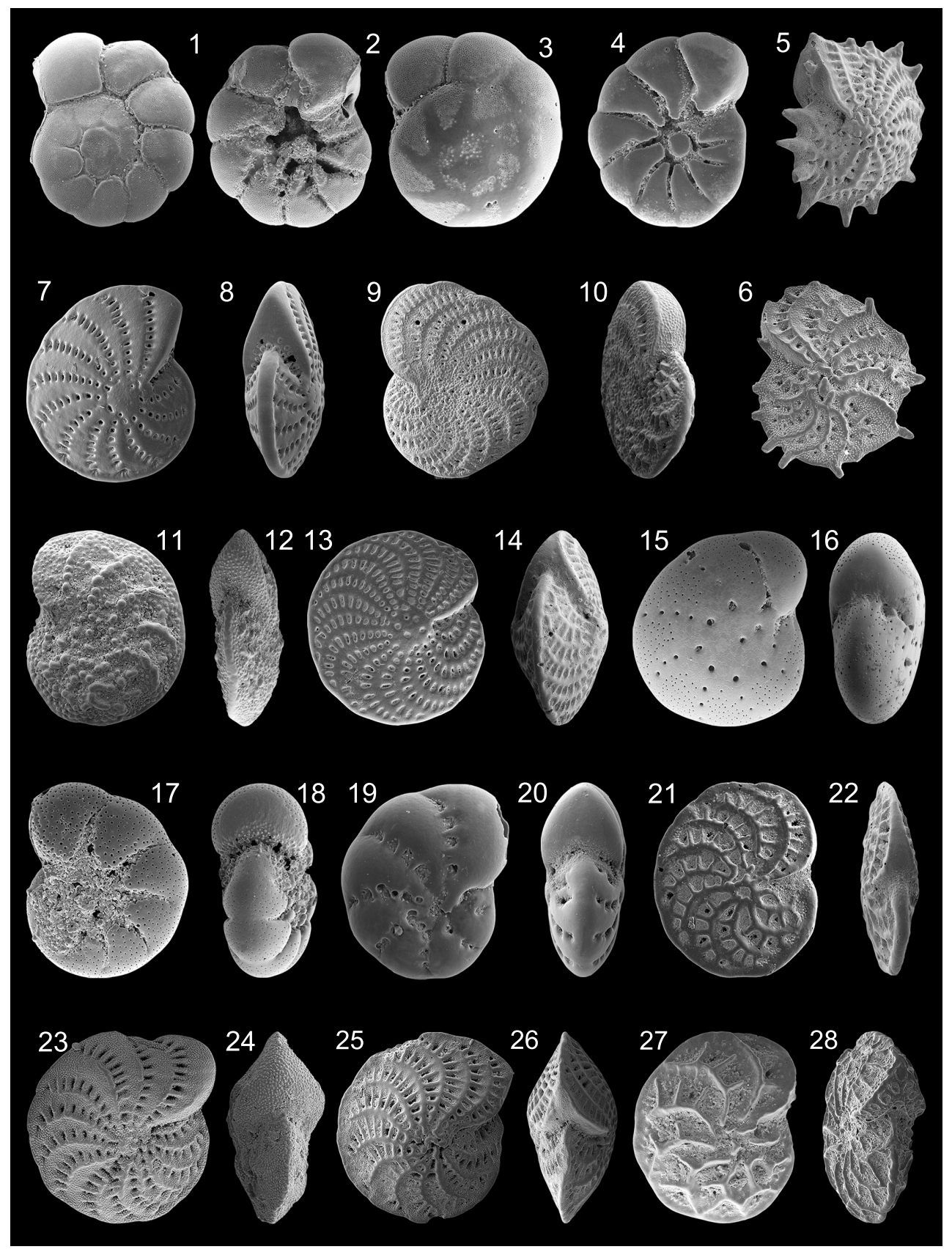

FIGURE 27. 1 Ammonia beccarii (Linné), 496x, spiral side; 2 A. beccarii (Linné), 431x, umbilical side; 3 Ammonia parkinsoniana (d'Orbigny), 703x, spiral side; 4 A. parkinsoniana (d'Orbigny), 591x, umbilical side; 5 Elphidium aculeatum (d'Orbigny), 245x, oblique side view; 6 E. aculeatum (d'Orbigny), 425x, side view; 7 Elphidium advenum (Cushman), 301x, side view; 8 E. advenum (Cushman), 330x, peripheral view; 9 Elphidium complanatum (d'Orbigny), 295x, side view; 10 E. complanatum (d'Orbigny), 396x, peripheral view; 11 Elphidium complanatum (d'Orbigny) var. tyrrhenianum Accordi, 1070x, side view; 12 E. complanatum (d'Orbigny) var. tyrrhenianum Accordi, 548x, peripheral view; 13 Elphidium crispum (Linné), 194x, side view; 14 E. crispum (Linné), 234x, peripheral view; 15 Elphidium decipiens (Costa), 889x, side view; 16 E. decipiens (Costa), 469x, peripheral view; 17 Elphidium granosum (d'Orbigny), 635x, side view; 18 E. granosum (d'Orbigny), 648x, peripheral view; 19 Elphidium incertum (Williamson), 705x, side view; 20 Elphidium incertum (Williamson), 996x, peripheral view; 21 Elphidium macellum (Fichtel and Moll), 418x, side view; 22 E. macellum (Fichtel and Moll), 446x, peripheral view; 23 Elphidium margaritaceum (Cushman), 333x, side view; 24 E. margaritaceum (Cushman), 452x, peripheral view; 25 Elphidium sp. 1, 274x, side view; 26 Elphidium sp. 1, 266x, peripheral view; 27 Parrellina verriculata (Brady), 1020x, side view; 28 P. verriculata (Brady), 761x, peripheral view. 
riomarginal, extraumbilical arch-shaped opening. The test surface is smooth.

Ammonia parkinsoniana (d'Orbigny, 1839a) Figure 27.3-4

1839a Rosalina parkinsoniana d'Orbigny: p. 99, pl. 4, figs. 25-27

1960 Streblus parkinsonianus (d'Orbigny); Hofker, p. 254, pl. E. fig. 132

1991 Ammonia parkinsoniana (d'Orbigny); Cimerman and Langer, p. 76, pl. 87, figs. 7-9

1993 Ammonia parkinsoniana (d'Orbigny); Sgarrella and Moncharmont Zei, p. 228, pl. 20, figs. 3, 4

2004 Ammonia parkinsoniana (d'Orbigny); Chendes et al., p. 76, pl. 4, fig. 4

2004 Ammonia parkinsoniana (d'Orbigny); Fiorini, p. 52, pl. 2, figs. 9, 10

2005 Ammonia parkinsoniana (d'Orbigny); Rasmussen, p. 107, pl. 18, figs. 5-8

2006 Ammonia parkinsoniana (d'Orbigny); Avsar et al., p. 133, pl. 3, figs. 15, 16

Remarks: The wall is calcareous, finely and densely perforate on the spiral side and along the peripheral margin on the umbilical side. The test is low trochospiral and planoconvex, with an evolute spiral and a flattened umbilical side. Chambers are triangular on the umbilical side and inflated and subglobular on the spiral side. Sutures are deeply incised, radial and curved on the umbilical side. In the umbilical region, an umbilical knob is present. The thickened sutures on the spiral side are slightly raised in the early part, later flush with the surface and depressed, and are radial, curved and imperforate. The aperture is an interiomarginal opening, extending slit-like along the base of the final chamber into the umbilical region. The test surface is smooth.

Family ELPHIDIIDAE Galloway, 1933

Subfamily ELPHIDIINAE Galloway, 1933

Genus ELPHIDIUM de Montfort, 1808

Elphidium aculeatum (d'Orbigny, 1846)

Figure 27.5-6

1846 Polystomella aculeata d'Orbigny: p. 131, pl. 6, figs. 27, 28

1884 Polystomella macella (Fichtel and Moll) (juvenile specimen); Brady, p. 737, pl. 110, fig. 10
1991

Elphidium

aculeatum

(d'Orbigny);

Cimerman and Langer, p. 77, pl. 89, figs. 1-4

1994 Elphidium aculeatum (d'Orbigny); Jones, p. 109, pl. 110, fig. 10 [cop. Brady, 1884, fig. 10]

2005 Elphidium aculeatum (d'Orbigny); Rasmussen, p. 108, pl. 18, fig. 12

Remarks: The wall is calcareous. The test is planispirally enrolled, involute and lenticular in peripheral view. The peripheral margin is acute and ornamented with thick and short pseudospines. Sutures are backward curved and incised. Ponticuli are gently curved. The fossettes between the ponticuli are elongate to subelliptical. The umbilical region is covered by granules. The primary aperture consists of interioareal openings, each of them bordered by a rim. Test surface is densely ornamented with pustules.

Elphidium advenum (Cushman, 1922c) Figure 27.7-8

1922c Polystomella advena Cushman: p. 56, pl. 9, figs. 11,12

1933c Elphidium advenum (Cushman); Cushman, p. 50 , pl. 12 , figs. $1-3$

1958 Elphidium advena (Cushman); Parker, p. 269 , pl. 4, figs. 3,4

1993 Elphidium advenum (Cushman); Hottinger, Halicz and Reiss, p. 146, pl. 207, figs. 1-7

1993 Elphidium punctatum (Terquem); Sgarrella and Moncharmont Zei, p. 230, pl. 21, figs. 3, 4

1995 Elphidium punctatum (Terquem); Coppa and Di Tuoro, p. 172, pl. 4, fig. 11

2005 Elphidium advenum (Cushman); Rasmussen, p. 108 , pl. 18 , figs. $13-15$

Remarks: The wall is calcareous and densely and finely perforate except for the periphery. The test is planispirally enrolled, involute and lenticular in peripheral view. Chambers are numerous and narrow, gradually increasing in size as added. The periphery is carinate. Sutures are backward curved and depressed. The fossettes between the ponticuli are subrounded to elliptical and ornamented with minute pseudospines. The umbilical region has a slightly developed knob. The primary aperture consists of interiomarginal and rounded openings at the base of the final chamber, each of them bordered by a rim. The test surface is smooth. 
Elphidium complanatum (d'Orbigny, 1839b)

Figure 27.9-10

1839b Polystomella complanata d'Orbigny: p. 129 , pl. 2, figs. 35,36

1958 Elphidium complanatum (d'Orbigny); Parker, p. 270, pl. 4, fig. 5

1933c Elphidium jenseni (Cushman); Cushman, p. 48 , pl. 11 , figs. 6,7

1991 Elphidium jenseni (Cushman); Cimerman and Langer, p. 78, pl. 92, figs. 1-3

1993 Elphidium jenseni (Cushman); Hottinger, Halicz and Reiss, p. 148, pl. 211, figs. 8-14

1993 Elphidium complanatum (d'Orbigny); Sgarrella and Moncharmont Zei, p. 228, pl. 20, figs. 9,10

2005 Elphidium jenseni (Cushman); Debenay et al., p. 336 pl. 3, figs. 26,27

2005 Elphidium complanatum (d'Orbigny); Rasmussen, p. 109, pl. 19, fig. 2

2006 Elphidium complanatum (d'Orbigny); Avsar et al., p. 134, pl. 3, fig. 19

Remarks: The wall is calcareous. The test is planispirally enrolled, slightly involute and flattened in peripheral view. Chambers are numerous and narrow. The peripheral margin is acute. Sutures are backward curved and depressed. The numerous ponticuli are elongate and ornamented with minute pseudospines. The primary aperture consists of a row of interiomarginal openings. The test surface is densely ornamented with pustules that are larger in the umbilical region and smaller on the rest of the test surface and on the apertural face.

\section{Elphidium complanatum (d'Orbigny) var. tyrrhenianum Accordi, 1951}

Figure 27.11-12

1950 Elphidium complanatum (d'Orbigny) var. tyrrhenianum Accordi: p. 126, pl. 2, figs. a, b (fide Ellis and Messina, 1940ff)

2005 Elphidium complanatum (d'Orbigny) var. tyrrhenianum Accordi; Rasmussen, p. 109, pl. 19 , fig. 3

Remarks: The wall is calcareous and finely perforate. The test is planispirally enrolled, involute and depressed (but lesser depressed than Elphidium complanatum) and subelliptical in peripheral view. Chambers are numerous and narrow. The peripheral margin is acute and carinate. Sutures are backward curved and depressed. The umbilical region is slightly depressed. The primary aperture consists of a row of interiomarginal openings. The test surface is densely ornamented with pustules that are larger in the apertural region.

$$
\begin{gathered}
\text { Elphidium crispum (Linné, 1758) } \\
\text { Figure 27.13-14 }
\end{gathered}
$$

1758 Nautilus crispum Linné: p. 709

1846 Polystomella crispa Lamarck; d'Orbigny, p. 125, pl. 6, figs. 9-14

1914 Polystomella crispa (Linné); Cushman, p. 32, pl. 18, fig. 1

1933c Elphidium crispum (Linné); Cushman, p. 47, pl. 11, fig. 4

1960 Elphidium crispum (Linné); Hofker, p. 258, pl. F, fig. 184

1987 Elphidium crispum (Linné); Alberola et al., p. 322 , pl. 4 , fig. 2

1987 Elphidium crispum forma crispum (Linné); Jorissen, p. 41, pl. 3, fig. 8

1988 Elphidium crispum (Linné); Loeblich and Tappan, p. 199, pl. 786, figs. 8, 9; pl. 787, figs. $1-5$

1991 Elphidium crispum (Linné); Cimerman and Langer, p. 77, pl. 90, figs. 1-6

1993 Elphidium crispum (Linné); Sgarrella and Moncharmont Zei, p. 228, pl. 20, fig. 11

2005 Elphidium crispum (Linné); Debenay et al., p. 334 , pl. 2, fig. 23

2005 Elphidium crispum (Linné); Rasmussen, p. 109 , pl. 19 , fig. 4

2006 Elphidium crispum (Linné); Avsar et al., p. 134, pl. 3, fig. 20

2009 Elphidium crispum (Linné); Avsar et al., p. 135, pl. 3, figs. 19, 20

2009 Elphidium crispum (Linné); Frezza and Carboni, p. 55, pl. 1, fig. 16

Remarks: The wall is calcareous. The test is planispirally enrolled, involute and lenticular in peripheral view. Chambers are numerous and narrow. The peripheral margin is angular and carinate. Sutures are backward curved and depressed. Ponticuli are elongate, and fossettes between the ponticuli are rounded to elongate and ornamented with short pseudospines. The umbilical region has a plug. The primary aperture consists of a row of interiomarginal openings that are bordered by a rim. The test surface is ornamented with small pustules only in the apertural region. The test surface is smooth. 
Elphidium decipiens (Costa, 1856)

Figure 27.15-16

1856 Polystomella decipiens Costa: p. 224, pl. 19, figs. 13

1897 Polystomella decipiens Costa; Fornasini, p. 5, pl. 2, fig. 12

1916 Polystomella decipiens Costa; Heron-Allen and Earland, p. 282, pl. 43, figs. 20-22

1987 Elpidium poeyanum (d'Orbigny) forma decipiens (Costa); Jorissen, p. 38, pl. 2, fig. 6

1991 Elphidium translucens Natland; Cimerman and Langer, p. 79, pl. 92, figs. 7-11

1993 Elphidium cuvilleri Levy; Sgarrella and Moncharmont Zei, p. 239, pl. 20, fig. 13

2002 Elphidium translucens Natland; Kaminski et al., p. 176, pl. 5, fig. 12

2004 Cribroelphidium translucens (Natland); Fiorini, p. 54, pl. 3, figs. 9, 10

2005 Cribroelphidium translucens (Natland); Debenay et al., p. 336 pl. 3, fig. 20

2005 Elphidium decipiens (Costa); Rasmussen, p. 110 , pl. 19 , fig. 5

2009 Elphidium translucens Natland; Frezza and Carboni, p. 55, pl. 1, fig. 15

Remarks: The wall is calcareous, translucent and finely to coarsely perforate except for the apertural face. The test is planispirally enrolled and involute, with a broadly rounded periphery. Sutures are flush with the surface and backward curved. Ponticuli are only visible on the final chambers in the adult stage. The primary aperture consists of a row of interiomarginal openings. The test surface is smooth. Natland (1950) regarded E. translucens Natland later as a synonym of $E$. poeyanum (d'Orbigny). Jorissen (1987) regarded E. translucens Natland and E. cuvilleri Levy as synonyms of E. poeyanum (d'Orbigny) forma decipiens (Costa).

Elphidium granosum (d'Orbigny, 1826)

Figure 27.17-18

1826 Nonionina granosa d'Orbigny: p. 294, no. 8

1958 Elphidium granosum (d'Orbigny); Parker, p. 270 , pl. 4 , figs. 10,11

1987 Elphidium granosum forma granosum (d'Orbigny); Jorissen, p. 39, pl. 2, figs. 1, 2

1993 Elphidium granosum (d'Orbigny); Sgarrella and Moncharmont Zei, p. 229, pl. 21, figs. 1,2
1995 Cribroelphidium granosum (d'Orbigny); Coppa and Di Tuoro, p. 172, pl. 4, fig. 2

2004 Porosononion granosum (d'Orbigny); Chendes et al., p. 76, pl. 4, fig. 7

2005 Elphidium granosum (d'Orbigny); Rasmussen, p. 110 , pl. 19 , fig. 8

2005 Porosononion granosum (d'Orbigny); Debenay et al., p. 336 pl. 3, figs. 17, 18

2009 Porosononion subgranosum (Egger); Avsar et al., p. 135, pl. 3, figs. 17, 18

2009 Elphidium granosum (d'Orbigny); Frezza and Carboni, p. 57, pl. 2, fig. 5

Remarks: The wall is calcareous and densely and coarsely perforate except for the middle part of the apertural face. The test is planispirally enrolled and involute, with a rounded periphery and a weakly depressed umbilical region. Chambers are inflated and have a triangular plate-like feature. Sutures are incised and backward curved. The primary aperture consists of a row of interioareal openings, covered by pustules. The test surface is ornamented with pustules and granules in the umbilical region. A part of the apertural face is ornamented with pustules and pseudospines. The test surface is smooth.

Elphidium incertum (Williamson, 1858)

Figure 27.19-20

1858 Polystomella umbilicula Walker var. incertum Williamson: p. 44, pl. 3, fig. 82

1884 Polystomella striatopunctata Fichtel and Moll; Brady, p. 733, pl. 109, fig. 23

1930a Elphidium incertum (Williamson); Cushman, p. 18, pl. 7, figs. 4-9 [fig. 4: cop. Williamson, 1858, fig. 82; fig. 5: cop. Brady, 1884, fig. 23]

1993 Elphidium incertum (Williamson); Sgarrella and Moncharmont Zei, p. 229, pl. 21, fig. 5

1994 Cribrononion incertum (Williamson); Jones, p. 108, pl. 109, fig. 23 [cop. Brady, 1884, fig. 23]

2005 Elphidium excavatum (Terquem); Rasmussen, p. 110 , pl. 19, figs. 6,7

Remarks: The wall is calcareous, densely and coarsely perforate except for the apertural face. The test is planispirally enrolled and involute, with a rounded periphery, and subelliptical in peripheral view. The umbilical region is slightly depressed. Chambers are inflated. Sutures are depressed and backward curved. Ponticuli are present. Fossettes are crescentic and ornamented with minute pseu- 
dospines. The primary aperture consists of small and rounded interiomarginal openings, covered by small pustules. The test surface is smooth.

\section{Elphidium macellum (Fichtel and Moll, 1798)}

Figure 27.21-22

1798 Nautilus macellus Fichtel and Moll: p. 66, pl. 10, figs. e-g

1884 Polystomella macella (Fichtel and Moll); Brady, p. 737, pl. 110, figs. 8, 11

1914 Elphidium macellum (Fichtel and Moll); Cushman, p. 33, pl. 18, fig. 3

1987 Elphidium crispum forma macellum (Fichtel and Moll); Jorissen, p. 41, pl. 3, fig. 9

1988 Elphidium macellum (Fichtel and Moll); Loeblich and Tappan, p. 199, pl. 789, figs. 1-5

1993 Elphidium macellum (Fichtel and Moll); Sgarrella and Moncharmont Zei, p. 229, pl. 20, fig. 12

1994 Elphidium macellum (Fichtel and Moll); Jones, p. 109, pl. 110, figs. 8, 11 [cop. Brady, 1884, figs. 8, 11]

2002 Elphidium macellum (Fichtel and Moll); Kaminski et al., p. 179, pl. 5, fig. 11

2004 Elphidium macellum (Fichtel and Moll); Fiorini, p. 54, pl. 3, figs. 1, 2

2005 Elphidium macellum (Fichtel and Moll); Rasmussen, p. 110, pl. 19, fig. 10

Remarks: The wall is calcareous. The test is planispirally enrolled, involute and flattened in peripheral view. Chambers are numerous and narrow. The peripheral margin is acute and carinate. Sutures are backward curved and depressed. The number of the ponticuli increases in the later chambers. Fossettes are ornamented with minute pseudospines. The primary aperture consists of a row of interiomarginal openings. The test surface is ornamented with small pustules in the apertural region and near the periphery.

Elphidium margaritaceum (Cushman, 1930a) Figure 27.23-24

1930a Elphidium advenum Cushman var. margaritaceum Cushman: p. 25, pl. 10, fig. 3

1991 Elphidium margaritaceum (Cushman); Cimerman and Langer, p. 79, pl. 92, figs. 4-6

1993 Elphidium pulvereum Todd; Sgarrella and Moncharmont Zei, p. 230, pl. 21, fig. 6
2005Elphidium margaritaceum (Cushman); Debenay et al., p. 336 pl. 3, fig. 11

2005 Elphidium margaritaceum (Cushman); Rasmussen, p. 111, pl. 19, figs. 13, 14

Remarks: The wall is calcareous. The test is planispirally enrolled and involute, lenticular in peripheral view. The peripheral margin is acute. Sutures are backward curved and depressed. The umbilical region is depressed. Numerous ponticuli are present. The fossettes between the ponticuli are elongate and ornamented with minute pseudospines. The primary aperture consists of a row of interiomarginal openings. The test is densely ornamented with small pustules and with some larger pustules in the apertural region and has a rough surface.

\section{Elphidium sp. 1}

Figure 27.25-26

1991 Elphidium sp. 4; Cimerman and Langer, p. 80 , pl. 91 , figs. 5,6

Remarks: The wall is calcareous and finely and densely perforate. The test is planispirally enrolled and involute, broadly lenticular in peripheral view. The peripheral margin is acute and carinate. The narrow chambers are numerous, gradually increasing in size as added. Sutures are backwards curved. Numerous ponticuli are present. The fossettes between the ponticuli are elliptical to elongate and ornamented with minute pseudospines. The primary aperture consists of a row of interiomarginal openings.

Subfamily NOTOROTALIINAE Hornibrook, 1961 Genus PARRELLINA Thalmann, 1951 Parrellina verriculata (Brady, 1881) Figure 27.27-28

1881 Polystomella verriculata Brady: p. 66

1884 Polystomella verriculata Brady; Brady, p. 738, pl. 110, fig. 12

1958 Parrellina verriculata (Brady); Parker, p. 271, pl. 4, fig. 7

1993 Parrellina verriculata (Brady); Sgarrella and Moncharmont Zei, p. 232, pl. 21, fig. 7

1994 Parrellina verriculata (Brady); Jones, p. 109, PI. 110, fig. 12 [cop. Brady, 1884, fig. 12]

Remarks: The wall is calcareous and finely perforate. The test is planispirally enrolled, involute and depressed in peripheral view. Chambers are numerous and increasing in size as added. Sutures are backward curved. The periphery is 
acute and carinate. The aperture consists of a row of interiomarginal openings. The test surface is ornamented with pustules and with granules in the umbilical part. Irregular ridges are present in the proximal part, perpendicular to the sutures.

\section{ACKNOWLEDGMENTS}

We thank the scientists and the ship crew of Meteor cruise 69/1 for excellent support and collaboration. We are grateful to the IFM-Geomar (Kiel) for providing storage capacities for the sediment cores and to J. Schönfeld for support during core sampling. We are grateful to C. Betzler for discussions and various support of the project. We further thank M. Theodor for making some of the SEM photographs. We greatly thank T.L. Rasmussen for her very helpful comments and suggestions, helping to improve a former version of the manuscript. We are also grateful to $\mathrm{C}$. Morigi and an anonymous reviewer for their suggestions and comments helping to improve the manuscript. This project was funded by the Deutsche Forschungsgemeinschaft (DFG), Project CARBMED.

\section{REFERENCES}

Abu-Zied, R.H., Rohling, E.J., Jorissen, F.J., Fontanier, C., Casford, J.S.L., and Cooke, S. 2008. Benthic foraminiferal response to changes in bottom-water oxygenation and organic carbon flux in the eastern Mediterranean during LGM to Recent times. Marine Micropaleontology, 67:46-68.

Accordi, B. 1951. I foraminiferi Tirreniani della Barma Grande. Annali dell'Università di Ferrara, 8:110-136.

Accordi, B. and Selmi, M. 1952. Micropaleontologia del Giacimento Pliocenico di Cornuda (Treviso), Annali dell'Universitá di Ferrara, Sezione IX, p. 69-104.

Alberola, C., Ferre, E.J., and Usera, J. 1987. Aportacion al Conocimiento de la fauna de foraminiferos bentonicos de las Islas Columbretes, p. 303-323. In Alonso Matilla, L.A., Carretero, J.L., and Garcia-Carrascosa, A.M. (eds.), Islas Combretes. Contribucion al estudio de su medio natural. Conselleria d'Obres Publiques, Urbanisme i Transports, Generalitat Valenciana, Valencia.

Alberola, C., Usera, J., and Garcia-Forner, A. 1991. Distribucion de las Tanatocenosis de foraminiferos arenaceos en el Puerto de Los Alfaques (Terragona). Revista Espanola de Paleontologia, Extraordinario:77-85.

Amore, F.O., Barra, D., Ciampo, G., Ruggiero Taddei, E., Russo, G.F., and Sgarrella, F. 1990. Paleoecologia dei depositi terrazzati della Starza (Pozzuoli), pp. 455-499. In Robba, E. (ed.), Proceedings of the Fourth Symposium of Ecology and Paleoecology of Benthic Communities. Museo Regionale di Scienze Naturali, Torino.
Andersen, H.V. 1952. Buccella, a new genus of the rotalid foraminifera. Journal of the Washington Academy of Sciences, 42:143-151.

Antoine, D., Morel A., and Morel, J.-M. 1995. Algal pigment distribution and primary production in the eastern Mediterranean as derived from costal zone color scanner observations. Journal of Geophysical Research, 100:16193-16206.

Arapova, N.D. and Suleymanov, I.S. 1966. O foraminiferakh iz Kon'yakskikh otlozheniy zapadnogo Uzebekistana I Kyzylkumov.Tashkentskiy Gosudarstvennyy Universitet im V.I. Lenina, 273:121-127. (In Uzbek)

Arnone, R. 1994. The temporal and spatial variability of chlorophyll in the Western Mediterranean, p. 195225. In La Violette, P.E. (ed.), Seasonal and Interannual Variability of the Western Mediterranean Sea, Coastal and Estuarine Studies, Volume 46, American Geophysical Union, Washington.

Asano, K. 1951. Illustrated catalogue of Japanese Tertiary smaller foraminifera, Part 13. Anomalinidae. Hosokawa Printing Company, Tokyo.

Avnimelech, M. 1952. Revision of the tubular Monothalamia. Contributions from the Cushman Foundation of Foraminiferal Research, 3:60-68.

Avsar, N., Aksu, A., and Dincer, F. 2006. Benthic foraminiferal assemblage of Erdek Bay (SW Marmara Sea). Yerbilimleri, 27:125-141.

Avsar, N., Meric, E., Cevik, M.G., and Dincer, F. 2009. Recent benthic foraminiferal assemblages on the continental shelf off the Büyük Menderes river delta (W Turkey). Yerbilimleri, 30:127-144.

Bailey, J.W. 1851. Microscopical examination of soundings made by the United States Coast Survey, off the Atlantic coast of the United States. Smithonian Contributions to Knowledge, 2 (art. 3):1-15.

Banner, F.T. and Culver, S.J. 1978. Quaternary Haynesina n. gen. and Paleogene Protelphidium Haynes; their morphology, affinities and distribution. Journal of Foraminiferal Research, 8:177-207.

Barker, R.W. 1960. Taxonomic notes on the species figured by H.B. Brady in his report on the foraminifera dredged by H.M.S. Challenger during years 18731876. Society of Economic Paleontologists and Mineralists, Special Publication Number 9:1-235.

Batsch, A.I.G.C. 1791. Sechs Kupfertafeln mit Cochylien des Seessandes, gezeichnet und gestochen von A.J.G.K. Batsch, Jena.

Bermudez, P.J. 1949. Tertiary smaller foraminifera of the Dominican Republic. Special Publications Cushman Laboratory for Foraminiferal Research, 25:1-322.

Bermudez, P.J. 1952. Estudio sistematico de los foraminíferos rotaliformes. Boletín de Geologia Venezuela, 2(4):1-230.

Berthelin, G. 1880. Memoire sur les Foraminiféres fossils de l'Etage Albien de Moncley (Doubs). Mémoires de la Société Géologique de France, Series 3 1(5):1-84. 
Berthelin, G. 1881. Coup d'oeil sur la faune rhizopodique du Calcaire Grossier Inférieur de la Marne. Compte rendu de I'Association Française pour l'Avancement des Sciences, $9^{\text {th }}$ sess. (Reims, 1880), pp. 553-559.

Berthois, L. and Le Calvez, Y. 1959. Deuxième contribution a l'étude de la sédimentation dans le Golfe de Gascogne. Revue des Travaux de I'Institut des Peches Maritimes, 23(3):323-376.

Betzler, C., Braga, J.C., Jaramillo-Vogel, D., Römer, M., Hübscher, C., Schmiedl, G., and Lindhorst, S. 2011. Late Pleistocene and Holocene cool-water carbonates in the Western Mediterranean Sea. Sedimentology, 58:643-669.

Bogdanovich, A.K. 1952. Miliolidy i Peneroplidy. Iskopaemye foraminifery. SSSR. Ibidem, 64:1-338.(In Russia)Bogdanovich, A.K. 1952. Miliolidy i Peneroplidy. Iskopaemye foraminifery. SSSR. Ibidem, 64:1338.(In Russia)

Boltovskoy, E. 1978. Late Cenozoic benthonic foraminifera of the Ninetyeast Ridge (Indian Ocean). Marine Geology, 26:139-175.

Boltovskoy, E. and Guissani de Kahn, G. 1983. Evaluation of benthic monothalamous foraminifers as guide fossils in Cenozoic deep-sea deposits of the south Atlantic. Micropaleontology, 29:298-308.

Bornemann, J.G. 1855. Die mikroskopische Fauna des Septarienthones von Hermsdorf bei Berlin. Zeitschrift der Deutschen geologischen Gesellschaft, 7:307371.

Brady, H.B. 1864. Contributions to the knowledge of the foraminifera. On the rhizopodal fauna of the Shetlands. The Transactions of the Linnean Society of London, 24:463-475.

Brady, H.B. 1879a. Notes on some reticularian Rhizopoda of the "Challenger" expedition, Part 1. Quaternary Journal of the Microscopical Science, 19 (new series):20-63.

Brady, H.B. 1879b. Notes on some reticularian Rhizopoda of the "Challenger" expedition, Part 2. Quaternary Journal of the Microscopical Science, 19 (new series):261-299.

Brady, H.B. 1881. Notes on some reticularian Rhizopoda of the "Challenger" expedition, Part 3. Quaternary Journal of the Microscopical Science, 21 (new series):31-71.

Brady, H.B. 1882. Report on the foraminifera, p. 708717. In Tizard, L. and Murray, J. (eds.), Exploration of the Faroe Channel, during summer of 1880 in H.M.S. "Knight Errant" with subsidiary reports. Proceedings of the Royal Society of Edinburgh vol. XL. Royal Society of Edinburgh, Edinburgh.

Brady, H.B. 1884. Report on the foraminifera dredged by H.M.S. Challenger during the years 1873-1876. In Report on the scientific results of the voyage of H.M.S. Challenger during the years 1873-1876. Zoology, 9, London.

Broennimann, P. 1976. Two new genera of Recent Trochamminidae (Foraminiferida). Archives des Sciences, Genève, 29:215-218.
Broennimann, P. and Beurlen, G. 1977. Recent benthonic foraminifera from Brazil. Morphology and ecology, Part I. Archives des Sciences, Genève, 30:7789.

Broennimann, P. and Whittaker, J.E. 1983. A lectotype for Deuterammina (Deuterammina) rotaliformis (Heron-Allen and Earland) and new trochamminids from E. Ireland (Protozoa: Foraminiferida). Bulletin of the British Museum (National History), Zoology Series, 45:347-358.

Broennimann, P. and Whittaker, J.E. 1984. On the foraminiferal genera Tritaxis Schubert and Trochamminella Cushman (Protozoa: Foraminiferida). Bulletin of the British Museum (Natural History), Zoology Series, 46:291-302.

Brotzen, F. 1942. Die Foraminiferengattung Gavelinella nov. gen. und die Systematik der Rotaliformes. Årsbok Sveriges Geologiska Undersökning, 36(8):1-60.

Brotzen, F. 1948. The Swedish Paleocene and its foraminiferal fauna. Årsbok Sveriges Geologiska Undersökning, 42(2):1-140.

Bruennich, M.T. 1772. M.T. Bruennichii Zoologiae fundamenta. Hafniae et Lipsiae: Grunde i Dyeloeren.

Buchner, P. 1940. Die Lagenen des Golfes von Neapel und der marinen Ablagerungen auf Ischia (Beiträge zur Naturgeschichte der Insel Ischia). Nova Acta Leopoldina, new series, 9(62):364-560.

Carpenter, W.B., Parker, W.K., and Jones, T.R. 1862. Introduction to the study of the Foraminifera. Ray Society, London.

Chapman, F. and Parr, W.J. 1931. Notes on new and aberrant types of foraminifera. Proceedings of the Royal Society of Victoria, new ser. 43:236-240.

Chapman, F., Parr, W.J., and Collins, A.C. 1934. Tertiary foraminifera of Victoria, Australia - The Balcombian deposits of Port Phillip, Part III. Journal of the Linnaean Society of London, Zoology 38:553-577.

Chendes, C., Kaminiski, M.A., Filipescu, S., Aksu, A.E., and Yasar, D. 2004. The response of modern benthic foraminiferal assemblages to water-mass properties along the southern shelf of Marmara Sea. Acta Palaeontologica Romaniae, 4:69-80.

Cherif, O.H. 1970. Die Miliolacea der Westküste von Naxos (Griechenland) und ihre Lebensbereiche. Unpublished PhD-Thesis, Fakultät der Natur- und Geisteswissenschaften, Technische Universität Clausthal, Germany.

Cimerman, F. and Langer, M.R. 1991. Mediterranean foraminifera. Slovenska Akademija Znanosti in Umetnosti. Academia Scientiarum et Artium Slovencia Cl. 4 Hist. Nat., 30, Ljubljana.

Coppa, M.G. and Di Tuoro, A. 1995. Preliminary data on the Holocene foraminifera of the Cilento continental shelf (Tyrrhenian Sea). Revista Espanola de Paleontologia, 10:161-174.

Corliss, B.H. 1979. Recent deep-sea benthonic foraminifera from the southeast Indian Ocean. Micropaleontology, 25:1-19. 
Costa, O.G. 1856. Paleontologia del regno di Napoli, Parte II. Atti dell'Accademia Pontaniana Napoli 7(2):113-378.

Cushman, J.A. 1910. A monograph of the foraminifera of the North Pacific Ocean, Part 1: Astrorhizidae and Lituolidae. Bulletin of the United States National Museum, 71(1):1-134.

Cushman, J.A. 1911. A monograph of the foraminifera of the North Pacific Ocean, Part 2: Textularidae. Bulletin of the United States National Museum, 71(2):1-108.

Cushman, J.A. 1913. A monograph of the foraminifera of the North Pacific Ocean, Part 3, Lagenidae. Bulletin of the United States National Museum, 71(3):1-122.

Cushman, J.A. 1914. A monograph of the foraminifera on the North Pacific Ocean, Part 4: Chilostomellidae, Globigerinidae, Nummulitidae. Bulletin of the United States National Museum, 71(4):1-46.

Cushman, J.A. 1915. A monograph of the foraminifera of the North Pacific Ocean, Part 5: Rotaliidae. Bulletin of the United States National Museum, 71(5):1-87.

Cushman, J.A. 1917. A monograph of the foraminifera of the North Pacific Ocean, Part 6: Miliolidae. Bulletin of the United States National Museum, 71(6):1-108.

Cushman, J.A. 1918. The foraminifera of the Atlantic Ocean, Part 1: Astrorhizidae. Bulletin of the United States National Museum, 104(1):1-111.

Cushman, J.A. 1920. The foraminifera of the Atlantic Ocean, Part 2: Lituolidae. Bulletin of the United States National Museum, 104(2):1-111.

Cushman, J.A. 1922a. The foraminifera of the Atlantic Ocean, Part 3: Textularidae. Bulletin of the United States National Museum, 104(3):1-143.

Cushman, J.A. 1922b. The foraminifera of the Byram Calcareous Marl at Byram, Mississipi, p. 82-281. In White, D. (ed.), Shorter Contributions to General Geology, US Geological Survey Professional Paper 129E, Washington.

Cushman, J.A. 1922c. Shallow water foraminifera of the Tortugas region. Carnegie Institution of Washington, Department of Marine Biology, 311:1-85.

Cushman, J.A. 1923. The foraminifera of the Atlantic Ocean, Part 4: Lagenidae. Bulletin of the United States National Museum, 104(4):1-129.

Cushman, J.A. 1924. Samoan Foraminifera. Carnegie Institution of Washington, no. 342, Department of Marine Biology, 21:1-75.

Cushman, J.A. 1926. Foraminifera of the typical Monterey of California. Contributions from the Cushman Laboratory for Foraminiferal Research, 2:53-69.

Cushman, J.A. 1927. An outline of a re-classification of the foraminifera. Contributions from the Cushman Laboratory for Foraminiferal Research, 3:1-105.

Cushman, J.A. 1928. Additional genera of the foraminifera. Contributions from the Cushman Laboratory for Foraminiferal Research, 4:1-8.

Cushman, J.A. 1929. The foraminifera of the Atlantic Ocean, Part 6: Miliolidae, Ophthalmidiidae, Fischerinidae. Bulletin of the United States National Museum, 104(6):1-129.
Cushman, J.A. 1930a. The foraminifera of the Atlantic Ocean, Part 7: Nonionidae, Camerinidae, Peneroplidae and Alveolinellidae. Bulletin of the United States National Museum, 104(7):1-79.

Cushman, J.A. 1930b. The foraminifera of the Choctawhatchee formation of Florida. Florida State Geological Survey Bulletin, 4:1-63

Cushman, J.A. 1931. The foraminifera of the Atlantic Ocean, Part 8: Rotaliidae, Amphisteginidae, Calcarinidae, Cymbalporettidae, Globorotallidae, Anomalinidae, Planorbulinidae, Pupertiidae and Homotremidae. Bulletin of the United States National Museum, 104(8):1-179.

Cushman, J.A. 1932. The foraminifera of the tropical Pacific collections of the "Albatross," 1899-1900, Part 1: Astrorhizidae to Trochamminidae. Bulletin of the United States National Museum, 161:1-88.

Cushman, J.A. 1933a. Foraminifera their classification and economic use. Special Publications Cushman Laboratory for Foraminiferal Research, 4:1-349.

Cushman, J.A. 1933b. Some new foraminiferal genera. Contributions from the Cushman Laboratory for Foraminiferal Research, 9:32-38.

Cushman, J.A. 1933c. The foraminifera of the tropical Pacific collections of the "Albatross," 1899-1900, Part 2: Lagenida to Alveolinellidae. Bulletin of the United States National Museum, 161:1-79.

Cushman, J.A. 1936. New genera and species of the families Verneuilinidae and Valvulinidae and of the subfamily Virgulininae. Cushman Laboratory for Foraminiferal Research, Special Publication, 6:1-71.

Cushman, J.A. 1937. A monograph of the foraminiferal family Valvulinidae. Special Publications Cushman Laboratory for Foraminiferal Research, 8:1-210.

Cushman, J.A. 1945. Foraminifera of the United States Antarctic Service Expedition 1939-1941. Reports on Scientific Results of the Antarctic Service Expedition, 1939-1941, Proceedings of the American Philosophical Society, 89:285-288.

Cushman, J.A. 1947. New species and varieties of foraminifera from off the southeastern coast of the United States. Contributions from the Cushman Laboratory for Foraminiferal Research, 23:86-92.

Cushman, J.A. and Edwards, P.G. 1937. Astrononion a new genus of the foraminifera, and its species. Contributions from the Cushman Laboratory for Foraminiferal Research, 13:29-36.

Cushman, J.A. and Martin, L.T. 1935. A new genus of foraminifera, Discorbinella, from Monterey Bay, California. Contributions from the Cushman Laboratory for Foraminiferal Research, 11:89-90.

Cushman, J.A. and McCulloch, I. 1939. A report on some arenaceous foraminifera. Allan Hancock Pacific Expeditions, 6:1-114.

Cushman, J.A. and Parker F.L. 1931. Recent foraminifera from the Atlantic coast of South America. Proceedings U.S. National Museum, 80(3):1-24. 
Cushman, J.A. and Parker F.L. 1936. Some species of Robertina. Contributions from the Cushman Laboratory for Foraminiferal Research, 12(4):92-100.

Cushman, J.A. and Stainforth, R.M. 1951. Tertiary foraminifera of coastal Ecuador: Part 1, Eocene. Journal of Paleontology, 25:129-164.

Cushman, J.A. and White, E.M. 1936. Pyrgoella, a new genus of the Miliolidae. Contributions from the Cushman Laboratory for Foraminiferal Research, 12:9091.

Czjzek, J. 1848. Beitrag zur Kenntnis der fossilen Foraminiferen des Wiener Beckens. Haidingers Naturwissenschaftliche Abhandlungen Wien, 2:137-150.

Debenay, J.-P., Millet, B., and Angelidis, M.O. 2005. Relationships between foraminiferal assemblages and hydrodynamics in the Gulf of Kalloni, Greece. Journal of Foraminiferal Research, 35:327-343.

de Folin, L. 1887. Les Rhizopodes reticulaires. Naturaliste, Paris, ser. 2(9):102-103, 113-115.

Defrance, J.L.M. 1824. Dictionnnaire des Science Naturelles 32. F.G. Levrault, Strasbourg.

Defrance, J.L.M. 1825. Dictionnaire des Science Naturelles 35. F.G. Levrault, Paris.

Delage, Y. and Herouard 1896. Traité de Zoologie Concrète, Vol. I, La Cellule et les Protozoaires. Schleicher Freres, Paris.

de Hornibrook, N. B. Tertiary foraminifera from Oamaru District (N.Z.), Part I - Systematics and distribution. Paleontological Bulletin, Wellington, 34:1-192.

de Lamarck, M. 1816. Histoire Naturelle des Animaux Sans Vertébres, présentant les caractères généraux et particuliers de ces animaux, leur distribution, leurs classes, leurs familles, leurs genres, et la citation des principales espèces qui s'y rapportent; précédée d'une introduction offrant la détermination des caractères essentiels de l'animal, sa distinction du végétal et des autres corps naturels; enfin, l'exposition des principes fondamentaux de la zoologi, 2, Paris.

de Montfort, D. de, 1808. Conchyliologie Systematique et Classification Methodique des Coquilles, Volume 1, F. Schoell, Paris.

Deshayes, G.P. 1832. Encyclopedie Methodique: Histoire naturelle des Vers, 3. Mme Agasse, Paris.

Di Napoli Alliata, E. 1952. Nuove specie di foraminiferi nel Pliocene e nel Pleistocene della zona di Castell'Arquato (Piacenza). Rivista Italiana di Paleontologia e Stratigrafia, 58:95-110.

d'Orbigny, A. 1826. Tableau Methodique de la Classe des Cephalopodes. Annales des Sciences Naturelles, 7:96-314.

d'Orbigny, A. 1839a. Foraminiféres, 224 pp.. In De la Sagra, R.M. (ed.), Histoire physique, politique et naturelle de L'ile de Cuba. Bertrand, A., Paris.

d'Orbigny, A. 1839b. Foraminiféres, p. 119-146. In Barker-Webb, P. and Berthelot, S. (eds.), Histoire Naturelle des Iles Canaries, Volume 2, Part 2, Bethune, Paris.
d'Orbigny, A. 1839c. Voyage dans l'Amerique Meridonale - Foraminiferes, part 5(5), Paris and Strasbourg.

d'Orbigny, A. 1846. Foraminiferes Fossiles Du Bassin Tertiaire De Vienne (Autriche). Gide et Comp, Libraires-Editeurs, Paris.

d'Orbigny, A. 1852. Prodome de paléontologie stratigraphique universelle des animaux mollusques \& rayonnés paisant suite au cours élémentaire de paléontologie et de géologie stratigraphiques, Vol 3. Victor Masson, Paris.

Dorreen, J.M. 1948. A foraminiferal fauna from the Kaiatan stage (upper Eocene) of New Zealand. Journal of Paleontology, 22:281-300.

Egger, J.G. 1857. Die Foraminiferen der Miocän Schichten bei Ortendorf in Niederbayern, p. 266-311. In von Leonhard, K.C. and Bronn, H.G. (eds.), Neues Jahrbuch für Mineralogie, Geognosie, Geologie und Petrefaktenkunde. E. Schweitzerbart'sche Verlagshandlung und Druckerei, Stuttgart.

Egger, J.G. 1893. Foraminiferen aus Meeresgrundproben, gelothet von 1874 bis 1876 von S.M. Sch. Gazelle. Abhandlungen der Bayrischen Akademie der Wissenschaften, Mathematisch-Physikalische Classe, 18:193-458.

Ehrenberg, C.G. 1838. Über dem blossen Auge unsichtbare Kalkthierchen und Kieselthierschen als Hauptbestandtheile der Kreidegebirge. Bericht über die zur Bekanntmachung geeigneten Verhandlungen der Königlichen Preußischen Akademie der Wissenschaften zu Berlin, 1838:192-200.

Ehrenberg, C.G. 1839. Über die Bildung der Kreidefelsen und des Kreidemergels durch unsichtbare Organismen. Abhandlungen der Königlichen Akademie der Wissenschaften zu Berlin, 1838:60-148.

Ehrenberg, C.G. 1843. Verbreitung und Einfluß des mikroskopischen Lebens in Süd- und Nord-Amerika. Abhandlungen der Königlichen Akademie der Wissenschaften, Berlin (1841):291-446.

Eimer, G.H.T. and Fickert, C. 1899. Die Artbildung und Verwandtschaft bei den Foraminiferen. Entwurf einer natürlichen Eintheilung derselben. Zeitschrift für Wissenschaftliche Zoologie, 65:599-708.

El-Nakhal, H.A. 1990. Septloculina, a new genus in Hauerininae (foraminifera). Micropaleontology, 36:88-95.

Ellis, B.F. and Messina, A. 1940-2005. Catalogue of Foraminifera. The Micropaleontology Project, Inc., New York; http.micropress.org/em.

Fichtel, L. v. and Moll, J.P.C. v. 1798. Testacea microscopica, aliaque minuta ex generibus Argonauta et Nautilus, ad naturam picta et descripta (Microscopische and andere kleine Schalthiere aus den Geschlechtern Argonaute und Schiffer). Camesina, Wien.

Finlay, H.J. 1939. New Zealand Foraminifera: Key species in stratigraphy - No. 1. Transactions of the Royal Society of New Zealand, 68:504-543. 
Finlay, H.J. 1947. New Zealand Foraminifera: Key species in stratigraphy - No. 5. New Zealand Journal of Science and Technology, 28(5):259-292.

Fiorini, F. 2004. Benthic foraminiferal associations from upper Quaternary deposits of southeastern Po plain, Italy. Micropaleontology, 50:45-58.

Fichtel, L. v. and Moll, J.P.C. v. 1798. Testacea microscopica, aliaque minuta ex generibus Argonauta et Nautilus, ad naturam picta et descripta (Microscopische and andere kleine Schalthiere aus den Geschlechtern Argonaute und Schiffer). Camesina, Wien.

Fleming, J. 1828. A History of British Animals Exhibiting the Descriptive Characters and Systematic Arrangement of the Genera and Species of Quadrupeds, Birds, Fishes, Mollusca and Radiata of the United Kingdom. Bell and Bradfute, Edinburgh.

Flint, J.M. 1899. Recent foraminifera, a descriptive catalogue of specimens dredged by the U.S. Fish Commision Streamer "Albatross." Report of the U.S. National Museum, Part I (1897):249-349.

Fornasini, C. 1888. Tavola paleo-protistographica. Bollettino della Societá Geologica Italiana, 8:44-48.

Fornasini, C. 1894. Quinto contributo alla conoscenza della microfauna Terziaria Italiana. Memorie della $R$. Accademie della Scienze dell'Instituto di Bologna, Scienze Naturali, Series 5(4):201-203.

Fornasini, C. 1897. Intorno ad alcuni foraminiferi illustrati da O.G. Costa. Rendiconto delle sessioni della Reale Accademia delle Scienze dell'Istituto di Bologna, 2:17.

Fornasini, C. 1898. Intorno a l'Uvigerina bononiensis Fornasini. Rivista Italiana di Paleontologia, 4:27-28.

Fornasini, C. 1901. Contributo a la conoscenza de le Bulimine Adriatiche. Memorie della Reale Accademia delle Scienze dell Instituto di Bologna, Series 5, 9:371-381.

Forskal, P. 1775. Descriptiones animalium. Hauniae. Carsten Niebuhr, Copenhagen.

Frezza, V. and Carboni, M.G. 2009. Distribution of recent foraminiferal assemblages near the Ombrone River mouth (Northern Tyrrhenian Sea, Italy). Revue de micropaleontologie, 52:43-66.

Galloway, J.J. 1933. A Manual of Foraminifera. Principal Press, Bloomington.

Glaessner, M.F. 1937. Die Entfaltung der Foraminiferenfamilie Buliminidae. Problemy Paleontologii, Paleontologicheskaya Laboratoriya Moskovskogo Gosudarstvennogo Universiteta, 2-3:411-422.

Gonzales-Donoso, J.M. 1969. Donées nouvelles sur la texture et la structure du test de quelqués foraminifères du Bassin de Grenade (Espagne). Revue de Micropaléontologie, 12:3-8.

Griffith, J.W. and Henfrey, A. 1875. The Micrographic Dictionary, Volume 1, $3^{\text {rd }}$ Edition. Van Voorst, London.

Haake, F.-W. 1977. Living benthic foraminifera in the Adriatic Sea: Influence of water depth and sediment. Journal of Foraminiferal Research, 7:62-75.
Haeckel, E. 1894. Systematische Phylogenie. Entwurf eines Natürlichen Systems der Organismen auf Grund ihrer Stammesgeschichte, Theil 1, Systematische Phylogenie der Protisten und Pflanzen. Georg Reimer, Berlin.

Hasegawa, S., Sprovieri, R., and Poluzzi, A. 1990. Quantitative analysis of benthic foraminiferal assemblages from Plio-Pleistocene sequences in the Tyrrhenian Sea, ODP LEG 107, p. 461-478. In Kastens, K.A. and Mascle, J. et al. (eds.), Proceedings of the Ocean Drilling Program, Scientific Results, Vol. 107, College Station, TX (Ocean Drilling Program), Texas.

Haynes, J.R. 1973. Cardigan Bay recent foraminifera. Bulletin of the British Museum Natural History (Zoology), Supplement 4:1-245.

Hedley, R.H., Hurdle, C.M., and Burdett, I.D.J. 1964. Trochammina squamata Jones and Parker (foraminifera) with observations on some closely related species. New Zealand Journal of Science, 7(3):417426.

Hermelin, J.O.R. and Scott, D.B. 1985. Recent benthic foraminifera from the central North Atlantic. Micropaleontology, 31:199-220.

Heron-Allen, E. and Earland, A. 1913. Clare Island Survey, Part 64, Foraminifera. Proceedings of the Irish Academy, 31:1-188.

Heron-Allen, E. and Earland, A. 1915. The foraminifera of the Kerimba Archipelo (Portuguese East Africa), Part II. Transactions of the Zoological Society of London, 20, Part 17:543-794.

Heron-Allen, E. and Earland, A. 1916. The foraminifera of the West of Scotland. Transactions of the Linnean Society of London, Series 2, 11:197-300.

Heron-Allen, E. and Earland, A. 1930a. The foraminifera of the Plymouth district. Journal of the Royal Microscopical Society, Series 3, 50:46-84.

Heron-Allen, E. and Earland, A. 1930b. The foraminifera of the Plymouth district II. Journal of the Royal Microscopical Society, Series 3, 50:161-199.

Hoeglund, H. 1947. Foraminifera in the Gullmar fjord and the Skagerak. Zoologiska Bidrag fran Uppsala, 26:3328.

Hofker, J. 1932. Notizen über die Foraminiferen des Golfes von Neapel III, Die Foraminiferenfauna des Ammontatura. Pubblicazioni della Stazione Zoologica di Napoli, 12:61-144.

Hofker, J. 1951a. The foraminifera of the Siboga Expedition, Part III. Siboga Expetitie, Monography IV, E.J. Bill, Leiden, pp. 1-513.

Hofker, J. 1951b. The toothplate Foraminifera. Archives Néerlandaises de Zoologie, 8(4):353-372.

Hofker, J. 1956. Tertiary foraminifera of coastal Ecuador: Part II, Additional notes on Eocene species. Journal of Paleontology, 30:891-958.

Hofker, J. 1960. Foraminiferen aus dem Golf von Neapel. Paläontologische Zeitschrift, 34:233-262.

Hofker, J. 1977. The foraminifera of Dutch tidal flats and salt marshes. Netherlands Journal of Sea Research, 11:223-296. 
Hofker, J. 1980. The foraminifera of the Saba Bank Expedition, 1972 (Cicar Cruises 34, 35). Zoologische Verhandelingen, 177:3-73.

Hohenegger, J. and Piller, W. 1975. Wandstrukturen und Grossgliederung der Foraminiferen. Sitzungsberichte der Österreichischen Akademie der Wissenschaften, Mathematisch-naturwissenschaftliche Klasse, Abteilung I, 184(1-5):67-96.

Hohenegger, J. and Piller, W. 1977. Die Stellung der Involutinidae Bütschli and Spirillinidae Reuss im System der Foraminiferen. Neues Jahrbuch für Geologie und Paläontologie, Monatshefte 1977, (7):407-418.

Hottinger, L., Halicz, E., and Reiss, Z. 1993. Recent foraminiferida from the Gulf of Aqaba, Red Sea. Academia Scientiarum et Artium Slovenica, Classis IV: Historia Naturalis, 33, Lubljana.

Howe, H.V. 1930. Distinctive new species of foraminifera from the Oligocene of Mississippi. Journal of Paleontology, 4:327-331.

Hyams-Kaphzan, O., Almogi-Labin, A., Sivan, D., and Benjamini, C. 2008. Benthic foraminifera assemblage change along the southeastern Mediterranean inner shelf due to fall-off of Nile-derived siliciclastics. Neues Jahrbuch für Geologie und Paläontologie, Abhandlungen, 248:315-344.

Jones, R.W. 1984. A revised classification of the unilocular Nodosariida and Buliminida (Foraminifera). Revista Española de Micropaleontología, 16:91-160.

Jones, R.W. 1994. The Challenger Foraminifera. Oxford University Press, Inc., New York.

Jones, T.R. 1895. A monograph of the foraminifera of the Crag, Part 2. Paleontographical Society London.

Jones, T.R. and Parker, W.K. 1860. On the Rhizopodal fauna of the Mediterranean, compared with that of the Italien and some other Tertiary deposits. Quarterly Journal of the Royal Meteorological Society, 16:292-307.

Jorissen, F.J. 1987. The distribution of benthic foraminifera in the Adriatic Sea. Marine Micropaleontology, 12:21-48

Kaminski, M.A., Aksu, A., Box, M., Hiscott, R.N., Filipescu, S., and Al-Salameen, M. 2002. Late Glacial to Holocene benthic foraminifera in the Marmara Sea: implications for Black Sea - Mediterranean Sea connections following the last deglaciation. Marine Geology, 190:162-202.

Karrer, F. 1868. Die miocene Foraminiferenfauna von Kostej im Banat. Sitzungeberichte der kaiserlichen Akademie der Wissenschaften, mathematisch naturwissenschaftliche Classe, 58:121-195.

Kisel'man, E.N. 1972. Verkhnemelovye i Paleotsenovye foraminifery novogo roda Spiroplectinella. Trudy Sibirskogo Nauchno-Issledovatel'skogo Instituta Geologii Geofizii i Mineral'nogo Syr'ya (SNIIGGIMS) Ministerstva Geologii i Okhrany Nedr SSSR, Novosibirsk 146, 134-140. (In Russian)
Kruit, C. 1955. Sediments of the Rhone Delta: Grain size and microfauna. Verhandelingen van het Koninklijk Nedarlandsch Geologisch Mijnbouwkundig Genootshap, Geologische Serie, 15(3):357-499.

Lacroix, E. 1932. Textularidae du plateau continental mediterraneen entre Saint Raphael et Monaco. Bulletin de L'Institut Oceanographique, Monaco, 591:128.

Lalicker, G.C. 1935. Two new foraminifera of the genus Textularia. Smithsonian Institution Miscellaneous Collections, Washington, 91(22):1-2.

Lalicker, G.C. and McCulloch, I. 1940. Some Textulariidae of the Pacific Ocean. Allan Hancock Pacific Expeditions, 6:115-143.

Lamarck, J.B. 1804. Suite des mémoires sur les fossils des environs de Paris. Annales Muséum National d'Histoire Naturelle, 5:179-188.

Le Calvez, Y. 1958. Le foraminiferes de la Mer Celtique. Revue des Travaux de I'Institut des Peches Maritimes, 22:147-209.

Le Calvez, Y. and Le Calvez, J. 1958. Répartition des foraminiféres dans la Baie de Villefrance, I. Miliolidae. Annales de L'Institut Océanographique, 35:159234.

Leiter, C. 2008. Benthos-Foraminiferen in Extremhabitaten: Auswertung von METEOR-Expeditionen vor Namibia. Unpublished Ph.D. Thesis, Ludwig-Maximilians-Universität, München, Germany.

LeRoy, D. and Levinson, S.A. 1974. A deep-water Pleistocene microfossil assemblage from a well in the northern Gulf of Mexico. Micropaleontology, 20:1-37.

L'Helguen, S., Le Corre, P., Madec, C., and Morin, P. 2002. New and regenerated production in the Almeria-Oran front area, eastern Alboran Sea. Deep-Sea Research I, 49:83-99.

Linné, C. 1758. Systema naturae per regna tria naturae, secundum classes, ordines, genera, species, cum characteribus, differentiis, synonymis, locis, 1, 10th edition. L. Salvii, Holmiae (Stockholm).

Loeblich, A.R., Jr. and Tappan, H. 1957. Eleven new genera of foraminifera. Bulletin of the United States National Museum, 215:223-232.

Loeblich, A.R., Jr. and Tappan, H., 1961. Supragenetic classification of the Rhizopodea. Journal of Paleontology, 35:245-330.

Loeblich, A.R., Jr. and Tappan, H. 1964. Sarcodina chiefly "Thecamoebians" and Foraminiferida. In R.C. Moore (ed.), Treatise on Invertebrate Paleontology, Part C. Protista 2. Lawrence, Geological Society of America and University of Kansas Press.

Loeblich, A.R., Jr. and Tappan, H. 1984. Some new proteinaceous and agglutinated genera of Foraminiferida. Journal of Paleontology, 58:1158-1163.

Loeblich, A.R., Jr. and Tappan, H. 1985. Some new and redefined genera and families of agglutinated foraminifera II. Journal of Foraminiferal Research, 15:175-217. 
Loeblich, A.R., Jr. and Tappan, H. 1986. Some new and revised genera and families of hyaline calcareous Foraminiferida (Protozoa). Transactions of the American Microscopical Society, 105:239-265.

Loeblich, A.R., Jr. and Tappan, H. 1988. Foraminiferal Genera and Their Classification. Van Nostrand Reinhold Company, New York.

Luczkowska, E. 1972. Miliolidae (Foraminiferida) from Miocene of Poland Part I. Revision of the classification. Acta Paleontologica Polonica, 17:341-377.

Luczkowska, E. 1974. Miliolilidae (Foraminiferida) from the Miocene of Poland. Part II. Biostratigraphy, palaeoecology and systematics. Acta Palaeontologica Polonica, 19:3-176.

Malmgren, B.A. and Haq, B.U. 1982. Assessment of quantitative techniques in paleobiogeography. Marine Micropaleontology, 7:213-230.

Marie, P. 1941. Les foraminiféres de la Craie a Belemnitella mucronata du Bassin de Paris. Mémoires du Museum Nationale d'Histoire Naturelle, n. Séries 12(1):1-296.

Masque, P., Fabres, J., Canals, M., Sanchez-Cabeza, J.A., Sanchez-Vidal, A., Cacho, I., Calafat, A.M., and Bruach, J.M. 2003. Accumulation rates of major constituents of hemipelagic sediments in the deep Alboran Sea: a centennial perspective of sedimentary dynamics. Marine Geology, 193:207-253.

Mathews, R.D. 1945. Rectuvigerina, a new genus of foraminifera from a restudy of Siphogenerina. Journal of Paleontology, 19:588-606.

Matthes, H.W. 1939. Die Lagenen des deutschen Tertiärs. Palaeontographica, Abt. A., 90:49-108.

Maync, W. 1952. Critical taxonomic study and nomenclatural revision of the Lituolidae based upon the prototype of the family Lituola nautiloidea Lamarck, 1804. Contributions from the Cushman Foundation for Foraminiferal Research, 3:35-56.

McCulloch, I. 1977. Qualitative Observations on Recent Foraminiferal Tests with Emphasis on the Eastern Pacific, Parts I-III. University of Southern California, Los Angeles.

McGowran, B. 1966. Australian Paleocene Lamarckina and Ceratobulimina with a discussion of Cerobertina, Pseudobulimina, and the family Robertinidae. Contributions from the Cushman Foundation for Foraminiferal Research, 17:77-103.

Medioli, F.S. and Scott, D.B. 1978. Emendation of the genus Discanomalina Asano and its implications on the taxonomy of some of the attached foraminiferal forms. Micropaleontology, 24:291-302.

Mehrnusch, M. 1993. Morphologische und strukturelle Merkmale einiger Bolivinen (Foraminiferida). Diskussion des taxonomischen Status von Afrobulimina, Brizalina, Bolivina and verwandten Taxa. Paläontologische Zeitschrift, 67:3-19.
Mendes, I., Gonzalez, R., Dias, J.M.A., Lobo, F., and Martins, V. 2004. Factors influencing recent benthic foraminifera distribution on the Guandiana shelf (Southwestern Iberia). Marine Micropaleontology, 51:171-192.

Mikhalevich, V.I. 1980. Novoe podsemeystvo Discammininae Mikhalevich, subfam. n. (Lituolidae, Foraminifera). In Novoe $v$ Sistematike Morskikh Bespozvochnykh Issledovaniya Fauny Morey, Zoologicheskiy Institut, Akademiya Nauk SSR, 25(33):57. (In Russian)

Milker, Y. 2010. Western Mediterranean shelf foraminifera: Recent distribution, Holocene sea-level reconstructions, and paleoceanographic implications. Unpublished Ph.D. Thesis, University of Hamburg, Hamburg, Germany. Access via http://ediss.sub.unihamburg.de/volltexte/2010/4709/

Milker, Y., Schmiedl, G., and Betzler, C. 2011. Paleobathymetric history of the Western Mediterranean Sea shelf during the latest glacial period and the Holocene: Quantitative reconstructions based on foraminiferal transfer functions. Palaeogeography, Palaeoclimatology, Palaeoecology, 307:324-338.

Milker, Y., Schmiedl, G., Betzler, C., Römer, M., Jaramillo-Vogel, D., and Siccha, M. 2009. Distribution of Recent benthic foraminifera in neritic carbonate environments of the Western Mediterranean Sea. Marine Micropalaeontology, 73:207-225.

Millett, F.W. 1898. Report on Recent foraminifera of the Malay Archipelago collected by Mr. A. Durrand, F.R.M.S., Part III. Journal of the Royal Microscopical Society (1900):539-549.

Millot, C., Taupier-Letage, I., and Benzohra, M. 1990. The Algerian eddies. Earth-Science Reviews, 27:203-219.

Milne-Edwards, A. 1881. Compte rendu sommaire d'une exploration zoologique, faite dans le Méditerranée á bord du navire de l'Etat "Le Travailleur," Compte Rendu Hebdomadaire des Séances de l'Académie des Sciences, Paris, 93:876-882.

Moebius, K.A. 1880. Foraminifera von Mauritius, pp. 65112. In Moebius, K.A. et al. (eds.), Beiträge zur Meeresfauna der Insel Mauritius und der Seychellen. Gutman, Berlin.

Mojtahid, M., Jorissen, F., Lansard, B., Fontanier, C., Bombled, B., and Rabouille, C. 2009. Spatial distribution of live benthic foraminifera in the Rhone prodelta: Faunal response to a continental-marine organic matter gradient. Marine Micropaleontology, 70:177-200.

Montagu, G. 1803. Testacea Brittanica or Natural History of British Shells Marine, Land and Fresh Water, Including the Most Minute. J.S. Hollis, Romsey.

Murray, J.W. 2003. An illustrated guide to the benthic foraminifera of the Hebridean shelf, west of Scotland, with notes on their mode of life. Paleaeontologia Electronica Vol. 5, Issue 1: 31p, 1.4MB;

http://palaeo-electronica.org/paleo/2002_2/guide/ issue2_02.htm. 
Natland, M.L. 1950. Part 4, Report on the Pleistocene and Pliocene foraminifera, 55p. In Anderson C.A., et al. (eds.), 1940 E.W. Scripps Cruise to the Gulf of California. The Geological Society of America Memoir 43, part 4, New York.

Nuglisch, K. 1985. Foraminiferen - marine Mikroorganismen. A. Ziemsen Verlag, Lutherstadt Wittemberg.

Pallas, P.S. 1766. Elenchus Zoophytorum sistens generum abumbrationes generaliores et specierum cognitarum succinctas descriptiones cum selectis auctorum synonymis. P. v. Cleef, The Hague.

Papp, A. 1953. Über die Entwicklung der Artengruppe der Uvigerina bononiensis Fornasini im Jungtertiär, p. 303-306, In Kober Festschrift. Skizzen zum Antlitz der Erde. Geologische Arbeiten, Universität Wien.

Parker, F.L. 1954. Distribution of the foraminifera in the northeastern Gulf of Mexico. Bulletin of the Museum of Comparative Zoology at Harvard College, 111:451588.

Parker, F.L. 1958. Eastern Mediterranean Foraminifera. Reports of the Swedish Deep-Sea Expedition, Sediment Cores from the Mediterranean Sea and the Red Sea, 8:217-285.

Parker, F.L. 1964. Foraminifera from the experimental Mohole Drilling near Guadalupe Island, Mexico. Journal of Paleontology, 38:617-636.

Parker, W.K. and Jones, T.R. 1865. On some foraminifera from the North Atlantic and Arctic Oceans, including Davis straits and Baffin's Bay. Philosophical Transactions of the Royal Society of London, 155:325-441.

Parr, W.J. 1932. Victorian and south Australian shallow water foraminifera, Part II. Proceedings of the Royal Society of Victoria, 44:218-235.

Parr, W.J. 1947. The Lagenid foraminifera and their relationships. Proceedings of the Royal Society of Victoria, n. Series 58:116-130.

Parr, W.J. 1950. Foraminifera. Reports B.A.N.Z. Antarctic Research Expedition 1929-1931, Series B (Zoology, Botany), 5(6):232-392.

Patterson, R.T. Richardson, R.P. 1987. A taxonomic revision of the unilocular foraminifera. Journal of Foraminiferal Research, 17:212-216.

Perconig, E. 1954. Note paleontologiche sulla zona costiera di Agrigento (Sicilia). Contributi di Scienze Geologiche con particolare riguardo all'Italia centrale, 3:91-98.

Perelis, L. and Reiss, Z. 1975. Cibicididae in recent sediments from the Gulf of Elat. Israel Journal of EarthSciences, 24:73-96.

Philippi, R.A. 1844. Enumeratio molluscorum siciliae cum viventium tum in tellure tertiaria fossilium. Anton, E., Halis Saxonum (Halle).

Phleger, F.B. 1965. Living benthic foraminifera from coastal marsh, southwestern Florida. Boletín de la Sociedad Geológica Mexicana, 28:45-60.
Phleger, F.B. and Parker, F.L. 1951. Ecology of foraminifera, northwest Gulf of Mexico, Part II, Foraminifera species. Geological Society of America Memoir, 46:1-59.

Piller, W. 1978. Involutinacea (Foraminifera) der Trias und des Lias. Beiträge zur Paläontologie von Österreich, 5:1-164.

Piller, W.E. 1983. Remarks on the suborder Involutinina Hohenegger and Piller, 1977. Journal of Foraminiferal Research, 13:191-201.

Piveteau, J. 1952. Traité de Paléontologie, Volume 1. Masson et Cie, Paris.

Pokorny, V. 1956. New Discorbidae (Foraminifera) from the upper Eocene brown Pouzdrany marl, Czechoslovakia. Universitas Carolina Geologica, 2:257-278.

Popescu, Gh. 1983. Marine Middle Miocene monothalamous foraminifera from Romania. Memorii Institutul de Geologie si Geofizikă Bucarest, 31:261-280.

Popescu, G. and Crihan, I.-M. 2004. Contributions to the knowledge of the calcareous unicameral foraminifera from the middle Miocene of Romania. Acta Palaeontologica Romaniae, 4:403-421.

Rasmussen, T.L. 1991. Benthonic and planktonic foraminifera in relation to the early Holocene stagnation in the Ionian Basin, central Mediterranean. BOREAS, 20:357-376.

Rasmussen, T.L. 2005. Systematic paleontology and ecology of benthic foraminifera from the Plio-Pleistocene Kallithea Bay section, Rhodes, Greece. Cushman Foundation Special Publication, 39:53-157.

Reiss, Z. 1963. Reclassification of perforate foraminifera. Bulletin of the Geological Survey of Israel, 35:1-111.

Reuss, A.E. 1848. Die fossilen Polyparien des Wiener Tertiärbeckens, p. 1-109. In Haidinger, W. (ed.), Naturwissenschaftliche Abhandlungen. Wilhelm Braumüller, Wien.

Reuss, A.E. 1850. Neue Foraminiferen aus den Schichten des österreichischen Tertiärbeckens. Denkschriften der mathematisch-naturwissenschaftlichen Classe der kaiserlichen Akademie der Wissenschaften (1849), 1:360-395.

Reuss, A.E. 1851. Über die fossilen Foraminiferen und Entostraceen der Septarienthone der Umgebung von Berlin. Zeitschrift der Geologischen Gesellschaft, 3:49-91.

Reuss, A.E. 1858. Über die Foraminiferen von Pietzbühl. Zeitschrift der Deutschen geologischen Gesellschaft, 10:433-438

Reuss, A.E. 1860. Die Foraminiferen der Westphälischen Kreideformation. Sitzungsberichte der Kaiserlichen Akademie der Wissenschaften in Wien, Mathematisch-Naturwissenschaftliche Classe, 40:147-238.

Reuss, A.E. 1861. Paläontologische Beiträge. Sitzungsberichte der kaiserlichen Akademie der Wissenschaften, mathematisch naturwissenschaftliche Classe, 44:301-342. 
Reuss, A.E. 1862. Entwurf einer systematischen Zusammenstellung der Foraminiferen. Sitzungsberichte der Kaiserlichen Akademie der Wissenschaften in Wien, Mathematisch-Naturwissenschaftliche Classe (1861), 44(1):355-396.

Reuss, A.E. 1863. Die Foraminiferen-Familie der Lageniden. Sitzungsberichte der kaiserlichen Akademie der Wissenschaften, Mathematisch-Naturwissenschaftliche Classe, 46:308-342.

Reuss, A.E. 1865. Die Foraminiferen, Anthozoen und Bryozoen des deutschen Septarientons - Ein Beitrag zur Fauna der mitteloligozänen Tertiärschichten. Denkschriften der kaiserlichen Akademie der Wissenschaften, Mathematisch-Naturwissenschaftliche Classe, 25:117-214.

Reuss, A.E. 1867. Die fossile Fauna der Steinsalzablagerung von Wieliczka in Galizien. Sitzungsberichte der Kaiserlichen Akademie der Wissenschaften, Mathematisch-Naturwissenschaftlichen Classe, 55:17-182.

Reuss, A.E. and Fritsch, A. 1861. Verzeichniss von 100 Gypsmodellen von Foraminiferen, welche unter der Leitung des Prof. Dr. A. Reuss und Dr. Anton Fritsch gearbeitet wurden. Karl Seyfried, Prague.

Revets, S.A. 1990. The genus Floresina, gen. nov. Journal of Foraminiferal Research, 20(2):157-161.

Rhumbler, L. 1906. Foraminiferen von Laysan und den Chatham-Inseln. Zoologischer Jahresbericht, 24:2180.

Rhumbler, L. 1911. Die Foraminiferen (Thalamophoren) der Plankton-Expedition, Erster Teil, Die Allgemeinen Organizationsverhältnisse der Foraminiferen. Ergebnisse der Planktonexpedition der Humboldt-Stiftung Kiel und Leipzig, Band 3 L.c. (1909):1-331.

Risso, A. 1826. Histoire Naturelle des Principales Productions de l'Europe Méridionale et Particulierment de Celles des Environs de Nice et des Alpes Maritimes, Volume 4, F.G. Levrault, Paris.

Rixen, M., Beckers, J.-M., Levitus, S., Antonov, J., Boyer, T., Maillard, C., Fichaut, M., Balopoulos, E., Iona, S., Dooley, H., Garcia, M.-J., Manca, B., Giorgetti, A., Manzella, G., Mikhailov, N., Pinardi, N., Zavatarelli, M., and the Medar Consortium 2005. The Western Mediterranean Deep Water: A proxy for climate change. Geophysical Research Letters, 32:1-9.

Robinson, A.R., Leslie, W.G., Theocharis, A., and Lascaratos, A. 2001. Mediterranean Sea circulation. Encyclopedia of Ocean Science, 3:1689-1705.

Roegl, F. 1968. Die miozäne Foraminiferenfauna von Laa an der Thaya in der Molassezone von Niederösterreich, Mitteilungen der Geologischen Gesellschaft, 61:63-123.

Rzehak, A. 1888. Die Foraminiferen der Nummulitenschichten des Waschberges und Michelsberges bei Stockerau in Nieder-Oesterreich. Verhandlungen der geologischen Reichsanstalt, 11:226-229.

Said, R. 1949. Foraminifera form the Northern Red Sea. Special Publication Cushman Laboratory for Foraminiferal Research, 26:1-44.
Saidova, Kh.M. 1975. Bentosnye Foraminifery Tikhogo Okeana, 3. Vol. Institut Okeanologii P.P. Shirshova, Akademiya Nauk SSR, Moscow. (In Russian)

Saidova, Kh.M. 1981. O sovremennom sostoyanii sistemi nadvidovykh taksonov Kaynozoyskikh bentosnykh foraminifer. Institut Okeanologii P.P. Shirshova, Akademiya Nauk SSSR, Moscow. (In Russian)

Sars, G.O. 1869. Fortsatte bemaerkninger over det dyriske livs Udredning i havets dybder. Forhandlinger i Videnskabs-Selskabet $i$ Christiana 1868, p. 246275.

Schiebel, R. 1992. Rezente benthische Foraminiferen in Sedimenten des Schelfes und oberen Kontinentalhanges im Golf von Guinea (Westafrika). BerichteReports, Geol. Paläont. Inst., Universität Kiel, 51:1126.

Schlumberger, C. 1891. Revision des Biloculines des grands fonds. Mémoires de la Société Zoologique de France, 4:542-579.

Schlumberger, C. 1893. Monographie des Miliolidees du Golf de Marseille. Mémoires de la Société Zoologique de France, 6:57-80.

Schlumberger, C. 1894. Note sur les foraminifères des mers arctiques russes. Mémoires de la Société Zoologique de France, 7:252-258.

Schroeter, J.S. 1783. Einleitung in die Conchilienkenntnis nach Linné, Erster Band. Gebauer, J.J, Halle.

Schubert, R.J. 1921. Palaeontologische Daten zur Stammesgeschichte der Protozoen. Paläontologische Zeitschrift (1920), 3:129-188.

Schuetz, K., Harzhauser, M., Rögl, F., Coric, S., and Galovic, I. 2007. Foraminiferen und Phytoplankton aus dem unteren Sarmatium des südlichen Wiener Beckens (Petronell, Niederösterreich). Jahrbuch der Geologischen Bundesanstalt, 147:449-488.

Schulze, F.E. 1875. Zoologische Ergebnisse der Nordseefahrt vom 21. Juli bis 9. September 1872, I Rhizopoden. 2. Jahresberichte der Kommission zur Untersuchung der deutschen Meere in Kiel (1874), p. 99-114.

Schultze, M.S. 1854. Über den Organismus der Polythalamien (Foraminiferen) nebst Bemerkungen über die Rhizopoden im Allgemeinen. Engelmann, W., Leipzig.

Schwager, C. 1866. Fossile Foraminiferen von Kar Nikobar, p. 187-268. In Reise der österreichischen Fregatte Novara um die Erde in den Jahren 1857, 1858, 1859; Geologischer Theil 2 (2. Abt.), Kaiserlichkönigliche Staatsdruckerei, Wien.

Schwager, C. 1876. Saggio du una classificazione dei foraminiferi avuto riguardo alle lore famiglie naturali. Bolletino R. Comitato Geologico d'Italia, 7:475-485.

Schwager, C. 1877. Quadro del proposto sistema di classificazione dei foraminiferi con guscio. Bolletino R. Comitato Geologico d'Italia, 8:18-27. 
Seguenza, G. 1862. Dei terreni Terziarii del distretto di Messina, Parte II, Descrizione dei foraminiferi monothalamici delle marne Mioceniche del distretto di Messina. Capra, T., Messina.

Seiglie, G.A. 1965a. Un genero Nuevo y dos especies nuevas de foraminiferos de Los Testigos, Venezuela. Boletin del Instituto Oceanográfico, Universidad de Oriente, Cumana, 4:51-59.

Seiglie, G.A. 1965b. Some observations on Recent foraminifers from Venezuela, Part I. Contributions from the Cushman Foundation for Foraminiferal Research, 16:70-73.

Seiglie, G.A. 1967. Systematics of the foraminifera from Araya-Los Testigos shelf and upper slope, Venezuela, with special reference to suborder Rotaliina and its distribution. Caribbean Journal of Science, 7:95133.

Seiglie, G.A. and Bermudez, P.J. 1965. Monografia de la familia de foraminiferos Glabratellidae. GEOS, 12:15-65.

Seiglie, G.A., Grove, K., and Rivera, J.A. 1977. Revision of some Caribbean Archaiasinae, new genera, species and subspecies. Eclogae Geologicae Helvetiae, 70:855-883

Selli, R. 1948. La struttura a del gen. Angulogerina Cushman 1927. Atti della Societa Italiana de Science Naturali e del Museo Civico di Storia Naturale, Milano, 87:40-48.

Sellier de Civrieux, J.M. 1977. Las Discorbidae del Mar Caribe, frente a Venezuela. Cuadernos Oceanográficos, Iniversidad de Oriente, Cumana, 6:1-44.

Sen Gupta, B.K.E. 2003. Modern Foraminifera. Kluwer Academic Publishers, Dordrecht.

Sgarrella, F. and Moncharmont Zei, M. 1993. Benthic foraminifera in the Gulf of Naples (Italy): systematics and autoecology. Bollettino della Societá Paleontologica Italiana, 32:145-264.

Shchedrina, Z.G. 1936. Alveolophragmium orbiculatum nov. gen. nov. sp.. Zoologischer Anzeiger, 114:312319.

Sidebottom, H. 1904. Report on the recent foraminifera from the coast of the Island of Delos (Grecian Archipelago), Part 1. Memoirs and Proceedings of the Manchester Literary and Philosophical Society (Manchester Memoirs), 48(5):1-26.

Sidebottom, H. 1908. Report on recent foraminifera on the coast of the Island of Delos (Grecian Archipelago), Part 5. Memoirs and Proceedings of the Manchester Literary and Philosophical Society (Manchester Memoirs), 52(13):1-29.

Sidebottom, H. 1918. Report on the recent foraminifera dredged off the east coast of Australia, H.M.S. "Dart," Station 19 (14. May 1895), Lat $29^{\circ} 22^{\prime}$ S., Long. $153^{\circ}$ 51' fathoms, Pteropod ooze, p. 1-26. In Hebb, R.G. and Singer, C. (eds.), Journal of the Royal Microscopical Society. London.

Silvestri, A. 1896. Foraminiferi pliocenici della Provincia di Siena, parte I. Memorie della Pontifacia Accademia Romana dei Nuovi Lincei, 12:1-204.
Silvestri, A. 1898. Foraminiferi pliocenici della Provincia di Siena, parte II. Memorie della Pontificia Accademia Romana dei Nuovi Lincei, 15:155-381.

Silvestri, A. 1904. Ricerche strutturali su alcune forme dei Trubi di Bonfornello (Palermo). Memorie della Pontificia Accademia Romana dei Nuovi Lincei, 22:235-276.

Silvestri, A. 1923. Lo stipite della Elissoforme e le sue affinitá. Memorie della Pontificia Accademia della Scienze, Nuovi Lincei, Series 2(6):231-270.

Souaya, F.J. 1965. Miocene foraminifera of the Gulf of Suez region, U.A.R. Part 1: Systematics (Astrohizoidea: Buliminoidea). Micropaleontology, 11:301-334.

Sprovieri, R. and Hasegawa, S. 1990. Plio-Pleistocene benthic foraminifer stratigraphic distribution in the Deep-Sea record of the Tyrrhenien Sea (OPD Leg 107), p. 429-459. In Kastens, K.A. and Mascle, J. (eds.), Proceedings of the Ocean Drilling Program, Scientific Results, Vol. 107, College Station, TX (Ocean Drilling Program), Texas.

Stache, G. 1864. Die Foraminiferen der tertiären Mergel des Whaingaroa-Hafens (Prov. Auckland). NovaraExpedition, 1857-1859, Volume 1, Geologischer Theil Number 2:159-304.

Steinmann, G. 1881. Die Foraminiferengattung Nummoloculina n.g.. Neues Jahrbuch für Mineralogie, Geologie und Paläontologie, 1:31-43.

Subbotina, N.N., Voloshina, N.A., and Azbel', A. Ya. (ed.) 1981. Vvedenie $v$ izuchenie foraminifer (klassifikatsiya melkikh foraminifer Mezo-Kaynozoya). Vsesoyuznyy Neftyanoy Nauchno-issledovatel'skii Geologorazvedochnyy Institut (VNIGRI), Leningrad. (In Russian)

Terquem, O. 1875. Essai sur le classement des animaux qui vivent sur la plage et dans les environs de Dunquerque. Memoirs de la Society Dunkerquoise (1876), 19:405-447.

Terquem, O. 1876. Essai sur le classement des animaux qui vivent sur la plage et dans les environs de Dunquerque, deuxieme fascicule: p. 55-100.

Terquem, O. 1878. Les Foraminiféres et les Entomostracés-Ostracodes du Pliocène Supérieur de L'ile de Rhodes, Premiére Section-Foraminiféres. Memoires de la Societe Geologique de France, Series 3(3):1135.

Thalmann, H.E. 1951. Mitteilungen über Foraminiferen IX. Eclogae Geologicae Helvetiae (1950), 43:221225.

Thalmann, H.E. 1952. Bibliography and index to new genera, species and varieties of foraminifera for the year 1951. Journal of Paleontology, 26:953-992.

Todd, R. 1958. Foraminifera from the Western Mediterranean deep-sea cores. Reports of the Swedish DeepSea Expedition, Sediment Cores from the Mediterranean Sea and the Red Sea, 8:167-215.

Todd, R. 1965. The foraminifera of the tropical Pacific collections of the "Albatross", 1899-1900, Part 4, Rotaliform families and planktonic families. United States National Museum Bulletin, 161:1-139. 
Velez-Belchi, P., Vargas-Yanez, M., and Tintore, J. 2005. Observation of a western Alboran gyre migration event. Progress in Oceanography, 66:190-210.

Vella, P. 1957. Studies in New Zealand foraminifera. Paleontological Bulletin, Wellington, 28:1-64.

Voloshinova, N.A. 1960. Uspekhi mikropaleontologii v dele izucheniya vnutrennego stroeniya foraminifer, pp. 48-87. In Trudy Pervogo Seminara po Mikrofaune. Vsesoyuznyy Neftyanoy Nauchno-issledovatel'skii Geologorazvedochnyy Institut (VNIGRI), Leningrad. (In Russian)

von Eichwald, C.E. 1830. Zoologia specialis, vol. 2. D.E. Eichwaldus, Vilnae.

Vyalov, O.S. 1968. Deyaki mirkuvannya pro klasifikatsiyu kremenistikh foraminifer. Dopovidi Akademu Nauk Ukraiins'koi RSR, Series B, Geologiya, Geofizika, Khimiya ta Biologiya 1968(1):3-6.

Walker, G. and Jacob, E. 1798. In Kanmacher, F. (ed.), Adam's Essay on the Microscope. Dillon and Keating, London.

Wedekind, P.R. 1937. Einführung in die Grundlagen der historischen Geologie, Band II, Mikrobiostratigraphie der Korallen- und Foraminiferenzeit. Ferdinand Enke, Stuttgart.

Weinhandl, R. 1958. Schackoinella, eine neue Foraminiferengattung. Verhandlungen der Geologischen Bundesanstalt Wien, 1958:141-142.

Werner, F.E., Vuidez, A., and Tintore, J. 1993. An explanatory numerical study of the currents off the southern coast of Mallorca including the Cabrera Island complex. Journal of Marine Systems, 4:45-66.
Wiesner, H. 1913. Notizen über die Fauna der Adria bei Rovigno. Zoologischer Anzeiger 16:521-528.

Wiesner, H. 1920. Zur Systematik der Miliolideen. Zoologischer Anzeiger, 51:13-20.

Wiesner, H. 1923. Die Miliolideen der östlichen Adria. The author, Prag-Bubanec.

Wiesner, H. 1931. Die Foraminiferen der deutschen Südpolar-Expedition 1901-1903, p. 49-165. In von Drygalski, E. (ed.), Deutsche Südpolarexpedition 19011903 (Volume 20), Zoologie 12, Walter de Gruyter and Co., Berlin und Leipzig

Williamson, W.C. 1848. On the Recent British species of the genus Lagena. The Annals and Magazine of Natural History, Series 2, 1:1-20.

Williamson, W.C. 1858. On the Recent foraminifera of Great Britain. Ray Society, London.

Wisshak, M. and Rueggeberg, A. 2006. Colonisation and bioerosion of experimental substrates by benthic foraminiferans from euphotic to aphotic depths (Kosterfjord, SW Sweden). Facies, 52:1-17.

Wollenburg, J. 1992. Zur Taxonomie von rezenten benthischen Foraminiferen aus dem Nansen Becken, Arktischer Ozean. Berichte zur Polarforschung, 112:1-137

Wright, J. 1900. The foraminifera of the Dogs Bay, Connemara. The Irish Naturalist, 9:51-55.

Wright, J. 1902. Foraminifera, p. 163-196. In Reade, T.M. (ed.), Glacial and post-glacial features of the lower valley of the river Lune and its estuary. Proceedings of the Liverpool Geological Society, Liverpool. 


\section{APPENDIX}

APPENDIX 1. Census counts live (Rose Bengal stained) benthic foraminifera in the surface samples from Alboran Platform, Oran Bight and Mallorca Shelf, with sample splits and sample volumens (available online).

APPENDIX 2. Census counts dead benthic foraminifera, sum benthic and planktonic foraminifera in the surface samples from Alboran Platform, Oran Bight and Mallorca Shelf, with sample splits and sample weights (available online).

APPENDIX 3. Census counts dead benthic foraminifera, sum benthic and planktonic foraminifera in sediment- core 342-1 from Alboran Platform with sample splits and sample weights (available online).

APPENDIX 4. Census counts dead benthic foraminifera, sum benthic and planktonic foraminifera in sedimentcore 367-1 from Oran Bight with sample splits and sample weights (available online).

APPENDIX 5. Census counts dead benthic foraminifera, sum benthic and planktonic foraminifera in sedimentcore 401-1 from Mallorca Shelf with sample splits and sample weights (available online). 